\title{
Nutrient use and recycling in urban, peri-urban and rural farms in Ethiopia
}
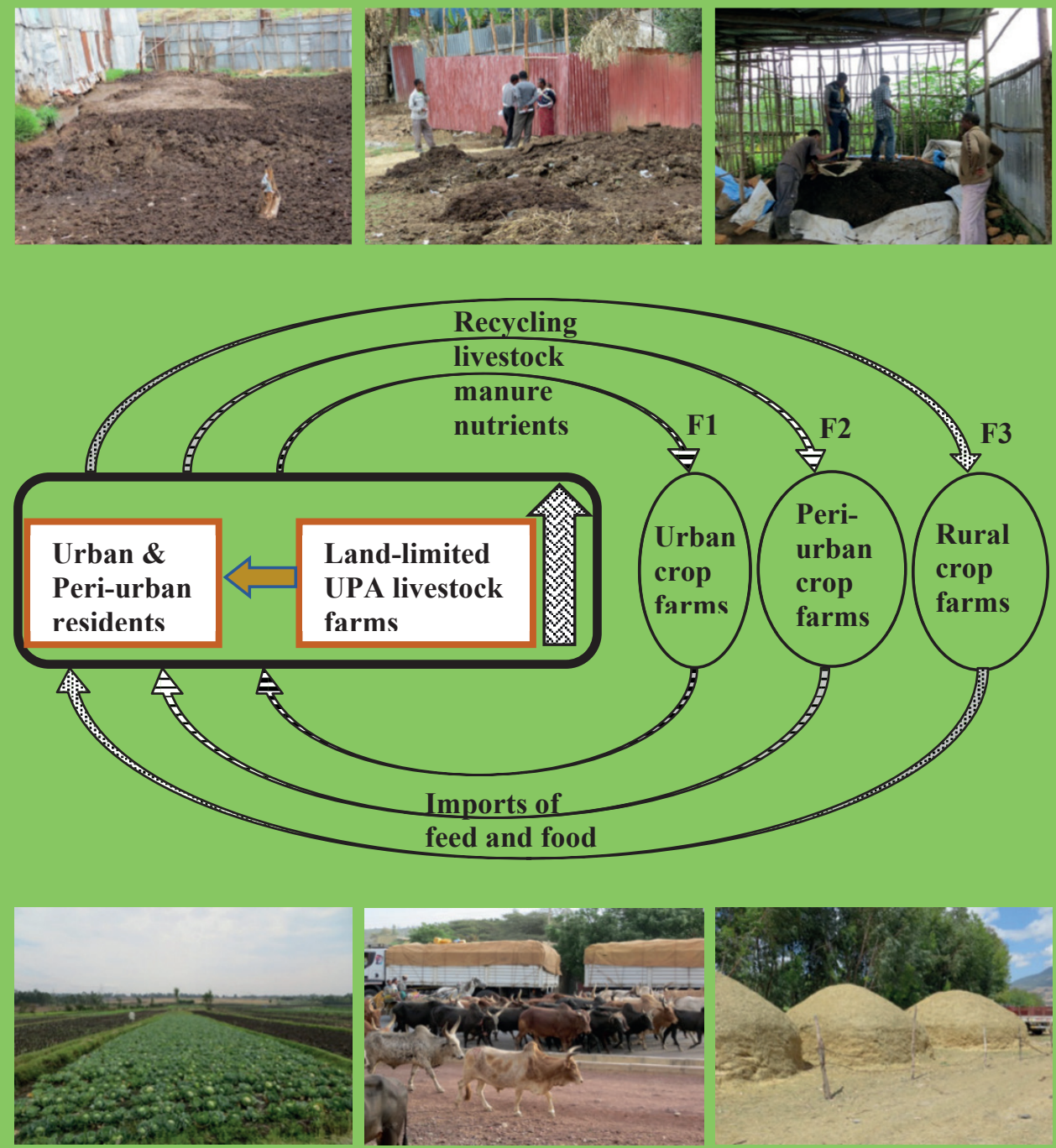

\section{Solomon Tulu Tadesse}





\section{Propositions}

1. Middlemen and incentives are needed for closing the nutrient loop between urban and rural areas in Ethiopia.

(this thesis)

2. Gradual losses of agricultural and urban green areas to urbanization are the neglected causes of reduced recycling of urban livestock manures and wastes.

(this thesis)

3. Reducing postharvest losses is as important as increasing crop and animal productivity for attaining greater food security in Ethiopia.

4. Climate change triggers the migration of coffee plantations to higher altitudes.

5. Publishing in high impact factor journals indicates a high impact of science on the quality of life in a society.

6. Ethnic diversity is a beauty, power, wealth and means of national unity, when a country recognizes and manages it.

Propositions belonging to the $\mathrm{PhD}$ thesis, entitled

Nutrient use and recycling in urban, peri-urban and rural farms in Ethiopia

Solomon Tulu Tadesse

Wageningen, 14 May 2021 



\section{Nutrient use and recycling in urban, peri-urban and rural farms in Ethiopia}




\section{Thesis committee}

\section{Promoter}

Prof. Dr O. Oenema

Special Professor, Nutrient Management and Soil Fertility

Wageningen University \& Research

\section{Co-promoters}

Dr C.L. van Beek

AgroCares, Wageningen

Prof. Dr F.L. Ocho

Professor of Plant Pathology \& Horticulture

Jimma University, Jimma, Ethiopia

\section{Other members}

Dr M. Slingeland, Wageningen University \& Research

Prof. Dr M. Rufino, Lancaster University, United Kingdom

Dr J.J. Stoorvogel, Wageningen University \& Research

Prof. Dr E.M.A. Smaling, Wageningen University \& Research

This research was conducted under the auspices of the C.T. de Wit Graduate School of Production Ecology and Research Conservation (PE\&RC) 


\title{
Nutrient use and recycling in urban, peri-urban and rural farms in Ethiopia
}

\section{Solomon Tulu Tadesse}

\author{
Thesis \\ submitted in fulfilment of the requirements for the degree of doctor \\ at Wageningen University \\ by the authority of the Rector Magnificus, \\ Prof. Dr A.P.J. Mol, \\ in the presence of the \\ Thesis Committee appointed by the Academic Board \\ to be defended in public \\ on Friday 14 May 2021 \\ at 1:30 p.m. in the Aula.
}


Solomon Tulu Tadesse

Nutrient use and recycling in urban, peri-urban and rural farms in Ethiopia, 184 pages.

PhD Thesis, Wageningen University, Wageningen, the Netherlands (2021) With references, with summaries in Dutch and English

ISBN 978-94-6395-733-5

DOI https://doi.org/10.18174/542694 


\begin{abstract}
Solomon Tulu T. 2021. Nutrient use and recycling in urban, peri-urban and rural farms in Ethiopia. PhD Thesis, Wageningen University, Wageningen, The Netherlands. 184 pp.
\end{abstract}

Urban population growth is rapidly increasing in developing countries, and fueling urban food demand. As a consequence, urban and peri-urban agriculture (UPA) is becoming important, providing food and jobs. Ethiopia is among the rapidly developing countries and the second most populous country in Africa after Nigeria. The diversity and performance of UPA in Ethiopia is not well-known, especially the use and recycling of nutrients in livestock manures and household wastes in UPA and rural farms are unknown.

The aim of this thesis is to increase the insights on the diversity and the performances of UPA farms, with focus on the use and recycling of nutrients in urban livestock manures and wastes, for closing the urban rural nutrient loops. A combination of farm surveys in three cities (Addis Ababa, Adama, and Jimma), nutrient budgeting, simulation modeling and field experiments were used to examine the current situation and to explore various scenarios for 2050. Three main scenarios were explored: (1) Increased urbanization, (2) Intensification of UPA and (3) Technological changes.

Six UPA farm types were distinguished: commercial livestock, commercial vegetable, subsistence field crop, and combinations of these three, through principal component analysis. Most of the farms were mixed farms, with variable proportions of nutrient resources allocated to livestock. Livestock farms had relatively high farm income and high $\mathrm{N}, \mathrm{P}$ and $\mathrm{K}$ surpluses, while subsistence field crop farms had low farm income and deficits of $\mathrm{N}, \mathrm{P}$ and $\mathrm{K}$ on the inputoutput balances. There was little or no exchange of manures and wastes between livestock farms and crop farms in the urban areas, and also no transfer of manures and wastes from the urban areas to the rural areas. UPA farms had on average positive $\mathrm{N}, \mathrm{P}$ and $\mathrm{K}$ balances while farms in the rural areas had negative $\mathrm{N}$ and $\mathrm{K}$ balances, but positive $\mathrm{P}$ balances (through the use of subsidized NP fertilizers). Estimates suggest that $0.5-2.6 \mathrm{Gg} \mathrm{N}$, 0.2-0.8 Gg P and 0.9-3.7 Gg K could have been collected in manures and household wastes in Addis Ababa year ${ }^{-1}$ in 2015, and recycled in crop farms, which would have saved 75-300 million Ethiopian Birr on synthetic fertilizers.

Forecasts indicate that the urban population in Ethiopia will increase by 3 to $5 \%$, and that UPA will also increase between 2015 and 2050. Scenario analyses indicated that livestock manures were the main organic wastes in the urban areas, although only $20-40 \%$ of animal source food consumed was produced in UPA, and only $14-19 \%$ of protein intake by citizens was animalbased. My scenario analyses suggest three important needs: (i) reducing population growth and urbanization, (ii) improving crop and livestock productivities and (iii) increasing manures and wastes recycling.

Key words: Balanced fertilization, circular economy, farm sustainability, nutrient allocation, food security, nutrient balances, urban agriculture, urban-rural nutrient loops, urbanization 



\section{Contents}

Abstract

Chapter 1 General Introduction

Chapter 2 Diversity and nutrient balances of urban and peri-urban agriculture (UPA) farms in Ethiopia

Chapter 3 Nitrogen allocation and recycling in peri-urban

mixed crop-livestock (MC-LS) farms in Ethiopia

Chapter 4 Manure recycling from urban livestock farms for closing the urban-rural nutrient loops

Chapter 5 Exploring the recycling of manure from urban livestock farms:

a case study in Ethiopia

Chapter 6 General Discussion

Appendix

Summary

Samenvatting

Acknowledgements

Publications

About the Author

179

Training and Education Statement

181

Funding

183

Parts of this thesis are published as peer-reviewed scientific articles. For this thesis, the texts of the published articles are integrally adopted. Editorial changes were made for reasons of uniformity of presentation in this thesis. References should be made to the original article (s). 



\section{CHAPTER 1}

General Introduction 


\subsection{Background}

Urbanization is one of the trends facing humanity (Khumalo and Sibanda, 2019). Globally, the ratio of rural to urban dwellers has decreased from 6.7 in 1900 to less than 1 in 2010 (Lerner and Eakin, 2011). Urbanization has multiple drivers and multiple effects. It influences human diets and global food demand (Shah and $\mathrm{Wu}, 2019$ ), mainly because of the growing demands for high value agricultural products (Satterthwaite et al., 2010). Urban expansion implies that more food will have to be available to the urban inhabitants, the net food buyers, living in the urban areas that has traditionally been perceived as inappropriate for agriculture (Szabo, 2015).

Urbanization also increases the pressure on the global food systems, because urban expansion is in direct competition with food production for land in peri-urban and ex-urban areas (Barthel et al., 2019). Forecasts suggest that urban expansion will result in a 1.8-2.4\% loss of global cropland by 2030 , and $80 \%$ of global cropland and $84 \%$ of global crop production losses are expected to occur in Africa and Asia (Bren d'Amour et al., 2017). Moreover, urban expansion will take place on cropland that is 1.77 times more productive than the global average and thus will lead to a total crop production loss of $3.7 \%$. These dynamics add pressure to the food systems and threatens livelihoods in vulnerable regions (Bren d'Amour et al., 2017). The food systems in developing countries, particularly in Africa and Asia with fast urbanization, will face significant pressure since urban expansion will be occurring on some of the world's most productive agricultural lands (Abu Hatab et al., 2019).

Urbanization also affects nutrient recycling and regional nutrient budgets. As a result of the demographic movement into the cities, nutrients flow towards the urban zone leading to nutrient accumulation in urban areas (Yu et al., 2017; Zhu et al., 2017). The transfer of nutrients to urban areas equally contributes to nutrient depletion in rural areas, where most of the food is produced. This is especially the case if inorganic fertilizers are inadequately used and/or animal manures and human wastes produced in urban and peri-urban areas are not recycled back to the rural areas (Goulding et al., 2008; Jones et al., 2013). The use of low external inputs and limited recycling of nutrients by the poor smallholders in rural areas lead to negative nutrient balances that render crop production unsustainable (Chianu et al., 2011; Grote et al., 2005). Native soil fertility exploitation coupled to inadequate use of inorganic and organic (e.g., animal manures) fertilizers (Chianu et al., 2011; van Beek et al., 2016), contribute to the disparity in soil nutrient balances between urban and rural areas (Jones et al., 2013; Potter et al., 2010).

Import of nutrients via agricultural products may further exacerbate inequitable distribution of nutrients between and within countries (Grote et al., 2005; Ma et al., 2014). For instance, West Asian, North African and sub-Saharan African (SSA) countries are net importers of nutrients through the import of agricultural products. However, the imported nutrients do not redress the widely recognized declines in the fertility of SSA soils, because the imported nutrients are mainly accumulated in the urban areas, creating waste disposal problems rather than alleviating the deficits of nutrients in the rural soils (Grote et al., 2005). 
Urbanization also may go along with increasing urban poverty, growing food insecurity and pollution of the environment, especially in developing countries (Orsini et al., 2013). For reducing the problems of urban wastes, improving urban biodiversity and overall abating the environmental impacts of food transport to urban areas and addressing urban food insecurity, urban and peri-urban agriculture may have a role to play (Eigenbrod and Gruda, 2014; Orsini et al., 2013; Zezza and Tasciotti, 2010).

\subsection{Urban and peri-urban agriculture (UPA)}

Urban and Peri-urban Agriculture (UPA) is defined as the practice of food production within the city boundary or in the immediate periphery (Castillo, 2003). UPA is a response to the expensive and often inadequate food supply in the rapidly increasing urban areas (Bon et al., 2010). It includes the growing of food crops, fruits, trees, herbs, flowers, aromatic plants, firewood and raising of animals including cattle, poultry, fish, bees and pigs (Castillo, 2003; Mulugeta, 2013). The increasing urban food demand provides a way for farming specialized in livestock and perishable products (vegetables) in and around cities, taking the advantages of market proximity and lack of infrastructures (good roads and functional cold chains) (Zezza and Tasciotti, 2010). Globally, UPA has been practiced since ancient times (Castillo, 2003) and has been expanding as a response to the food demands from the rapidly increasing urban population (Mulugeta, 2013).

UPA provides employment, income and food security to low-income urban residents. This is the case also in Sub Saharan African (SSA) countries, including Ethiopia, which are dented by poverty, rapid population growth and environmental degradation (Kwasi, 2010). Recent survey data show that increasing numbers of urban poor are engaged in diverse types of UPA systems as poverty alleviation strategies (Kwasi, 2010; Mulugeta, 2013). Diversity of UPA is large, as UPA systems can be adapted to a wide ranges of urban situations and to the needs of diverse stakeholders (Mulugeta, 2013). UPA is one of the largest employers in most cities of developing countries (Castillo, 2003). In Addis Ababa alone, there were 11,716 farming households (with average family size of 7) practicing UPA, producing 211,101 quintals of cereals and 153,662 quintals of vegetables in the 2011/2012 production season (Mulugeta, 2013). The majority of UPA farms in Ethiopia are family run, while group, co-operative and commercial farms are few in number. Use and level of technology in the majority of UPA farms are low (Dehinenet et al., 2014) and their farm practices are often environmentally unfriendly (Mulugeta, 2013).

Currently, UPA has not yet been embedded in urban planning and development strategies of SSA countries including Ethiopia (Mpofu, 2013) and Kenya (Korir et al., 2015). UPA is also facing food quality and safety issues, and marketing and delivery challenges, owing to lack of institutional and policy frameworks (Mpofu, 2013; Mulugeta, 2013). Some UPA practices including home-based dairy and poultry production may induce health risks. Animal manures are often found chaotically spread (not collected and not managed well), thereby polluting the urban environments as reported by Monney (2013) for the major cities of Accra and Kumasi 
in Ghana. Similarly, livestock farming in Addis Ababa, Adama and Jimma in Ethiopia is taking place in residential or business areas, and agricultural wastes such as discarded offal and manures are dumped along rivers and public areas such as road sides (Nigussie et al., 2015) due to lack of legal frameworks for the UPA sector (Mpofu, 2013; Mulugeta, 2013). To tap the potential of urban manures and wastes for crop farming and reduce their environmental impacts, the organic matter and nutrients in manures and wastes have to be managed and utilized in sustainable manners (Shah and Wu, 2019).

\section{$1.3 \quad$ Nutrient recycling}

Inefficient resource use, uneven food distribution and high rates of food waste in current food systems are commending for a transition towards more sustainable agriculture (Jurgilevich et al., 2016). Sustainable and resilient agricultural systems are needed to meet the growing demand of food for feeding the ever growing population (Landis, 2017), while conserving land and other resources (Wilhelm and Smith, 2017).

The 'Circular Economy' and 'circular food systems' have been presented as frameworks for developing more environmentally sustainable options of food production (de Boer and van Ittersum, 2018; Korhonen et al., 2018; Mylan et al., 2016). Farms are not circular food systems in themselves as they are designed to produce and market food, feed and fiber products. In return, these farms need nutrient inputs to maintain soil fertility in the long term. Coupling crop and animal production at farm or regional levels allows the recycling of nutrients from crop residues and animal manures for closing the nutrient loops between components of food production systems (Figure 1.1).

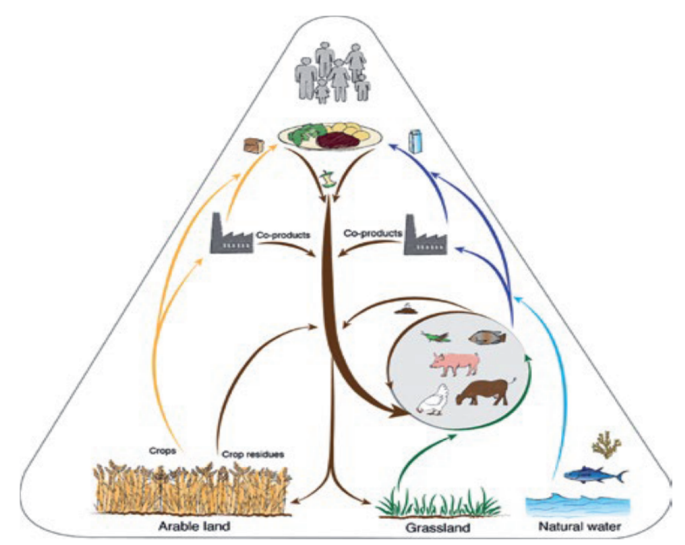

Figure 1.1 Concept of circular food systems. Arable land is used for crop source food production, crop by-products, grasslands and kitchen wastes are used to feed animals to produce animal source food, and animal manures and sewage wastes are used to replenish and support soil fertility (source: Van Zanten et al. (2018)). 
Coupling urban and rural areas allows the recycling of nutrients in wastes from food production, processing and consumption, and for closing the nutrient loops between areas of food production and food consumption. Nutrient recycling in food systems, by using locally available nutrient resources (e.g. crop residues, animal manures, food and sewage wastes), is vital for developing more sustainable food systems (Krause and Rotter, 2018). Godfray et al. (2010) indicated that reducing food losses and recycling wastes are important for enhancing food security and decreasing the environmental impacts of food production systems. Increasing nutrient recycling in food systems supports crop production, builds soil fertility and minimizes the environmental impacts of organic matter and nutrients from wastes (Ovsthus et al., 2017).

\subsection{Nutrient recycling and management in SSA}

Soil fertility and nutrient management are key factors determining agricultural productivity and sustainability in SSA (Tittonell et al., 2005). For decades, soil nutrient depletion has been a prime constraint for attaining food security in SSA (Hailu et al., 2015; Ugboh and Ulebor, 2011), and a main biophysical factor limiting agricultural productivity of smallholder farms (Drechsel et al., 2001a; Tittonell and Giller, 2013). Soils in large parts of SSA are strongly weathered and inherently low in organic matter (Ugboh and Ulebor, 2011; Zingore et al., 2015). The traditional farming methods have led to severe nutrient depletion and low crop yields due to low nutrient inputs and nutrient recycling. The situation is aggravated by lack of policy and institutional support, weak fertilizer markets, farmers' lack of access to credits and inputs, inappropriate fertilizer packaging sizes, declining agronomy capacity and weak agricultural extension (Chianu et al., 2011). The situation is further exacerbated by the lack of good farm data.

Soil nutrient balances can be used as an indicator to assess changes in soil fertility (Lesschen et al., 2007). Recent researches have indicated that SSA countries have on average a negative soil nutrient balance (Chianu et al., 2011). The amounts of N, P and K added as inputs were significantly less than the amounts removed via harvested crops and lost by erosion and leaching. The most critical threats to food production and ecosystem functioning in SSA are soil erosion, loss of organic matter and soil nutrient depletion (Chianu et al., 2011). Nutrient depletion accounted for about $7 \%$ of the agricultural share in the average GDP of SSA with national values going up to $25 \%$ (Drechsel et al., 2001a). A significant positive correlation was observed between population density and soil nutrient depletion (Drechsel et al., 2001b). Conversely, the declining soil fertility has been the fundamental impediment to agricultural development and the major reason for the slow growth in food production in for example Ethiopia where population growth has been fast (Hailu et al., 2015).

Nutrient balances may be defined at different scales, ranging from field to farm, to region and country, and from different components of food systems, depending on the specific questions (Cobo et al., 2010). The farm scale is most appropriate for assessing the performance of individual farms. The regional scale is increasingly used for assessing nutrient management, recycling and budgets in specific regions (Matsumoto et al., 2009). It offers opportunities for 
assessing the effects of regional farm characteristics on soil fertility and environmental impacts (MacDonald et al., 2011). The regional nutrient budget is strongly influenced by the type of farming systems, and the import and export of nutrients through fertilizers, feed, food, fiber and wastes (Kiboi et al., 2019).

The recycling of agricultural and other nutrient-rich organic wastes to meet crop nutrient needs is an essential component of a more sustainable food system (Akram et al., 2019). Reuse and recycling are essential tools for the development of a circular economy and improved economic and environmental sustainability (Toop et al., 2017). Although, the importance of nutrient recycling is known for long, the adoption of the concepts of recycling and circular food systems is insignificant in Ethiopian agriculture in general and in UPA in particular. This could be attributed to: (1) Shortage and competing use of crop residues for animal feed, biofuel and soil amendment; (2) Shortage and competing use of animal manures for biofuel, house construction and soil amendment; (3) Lack of knowledge, good farm data, advisory services, incentives and policies for the recycling of manures and wastes in crop farms.

\subsection{Motivation of my study}

UPA is becoming important for the livelihood of millions of urban residents in developing countries, providing jobs, food and income. This is also the case in Ethiopia, a rapidly developing country in SSA and the second most populous country in Africa (UN, 2015). However, the characteristics of the UPA systems and their agronomic, socioeconomic and environmental performances are largely unknown. Their roles in poverty alleviation and recycling of urban nutrient resources are also largely unknown (Mpofu, 2013). The extent, types and practices of UPA systems may vary across cities due to differences in socioeconomic conditions and urbanization patterns. Systematic inventories and classification of UPA will increase the understanding of UPA systems, will avoid misleading generalizations (Abdulkadir et al., 2013), and may provide the basis for deriving recommendations and guidelines for the further developing of UPA systems in the three main urban regions of Ethiopia selected for this study (Figure 1.2). Such recommendations and guidelines may be used by governmental agencies, private agri-business companies, universities, NGO's and extension services.

Currently, we know little about nutrient flows between intensive livestock production farms and crop farms in urban, peri-urban and rural areas. Earlier studies in West Africa, Kenya and Uganda have indicated that intensive livestock farms in the urban and peri-urban areas have large nutrient surpluses, while farms in the rural areas have nutrient deficits. How are the rapidly upcoming urban farms in Ethiopian cities influencing nutrient flows and recycling in urban, peri-urban and rural areas? What are the differences between farming systems in nutrient recycling? Which possible interventions may increase nutrient recycling between farms? Answers to these questions are needed to increase the understanding of the performances of the various farms and to derive guidelines for improving the sustainability of these farms. 


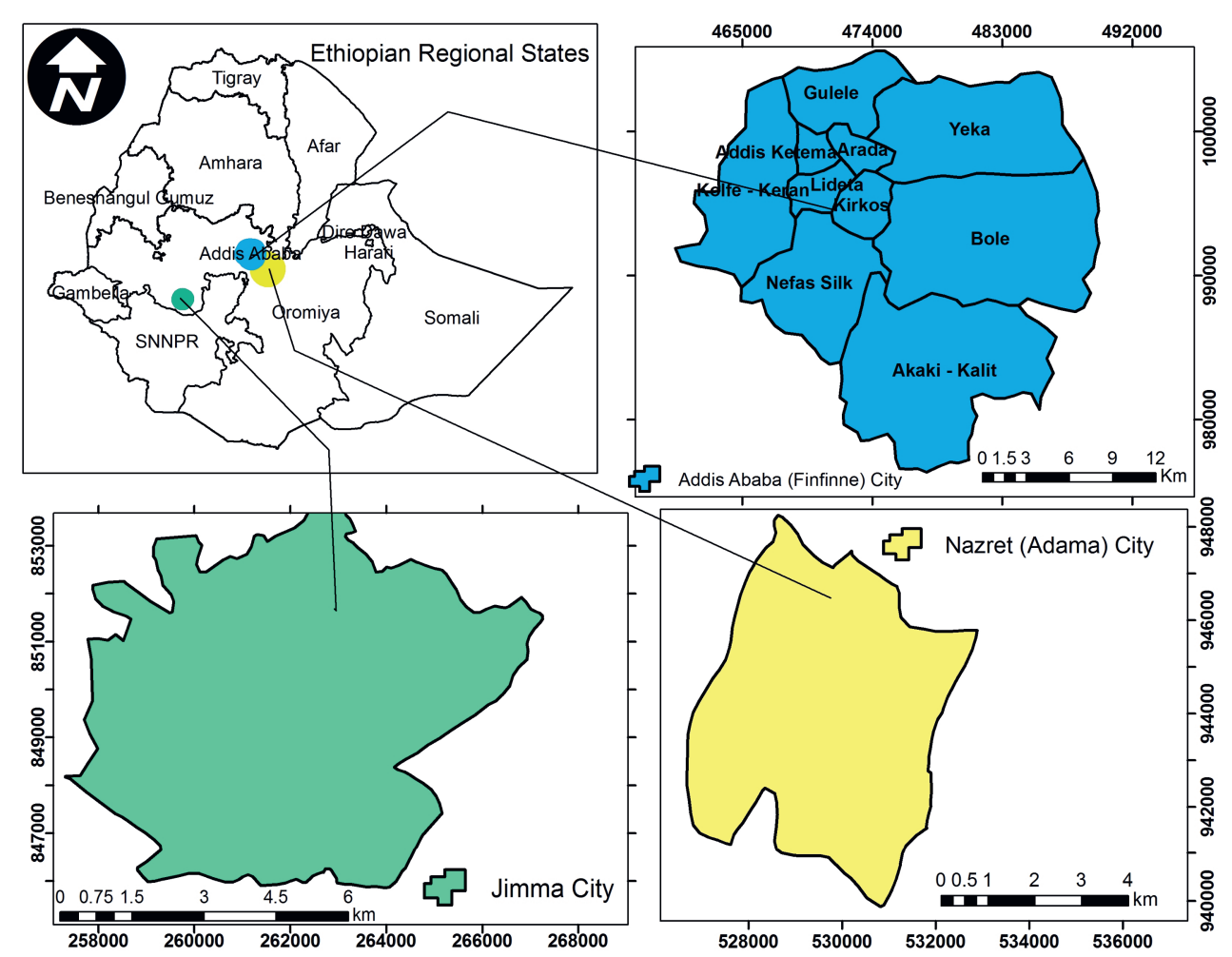

Figure 1.2 Maps of the study areas: Addis Ababa (Finfinne), Nazret (Adama) and Jimma in Ethiopia.

Many of the smallholder farms in urban, peri-urban and rural areas are mixed crop-livestock farms, but the relative importance of crops and livestock often greatly differs between mixed farming systems. Currently, we know little about the possible nutrient allocation strategies (between the crop and livestock compartments) within mixed farms and we don't have good indicators and quantitative data and information to characterize the nutrient allocation within these farms. Such information would be useful to further characterize nutrient recycling and nutrient use efficiency, and to derive policy recommendations for mixed farms within urban, peri-urban and rural areas.

While urbanization is rapidly progressing and UPA is rapidly developing, it is important to explore the quantitative potentials of recycling urban manure and waste nutrients to rural crop farms during the next decades. Economic costs of collecting, storage, composting and transport of manure and waste nutrients are likely important and will have to be considered in any program dealing with the recycling of nutrients from manure, kitchen waste and sewage waste. Next to economic cost there may be cultural and social barriers that have to be considered. Currently, there is very little information about the possible future developments of Ethiopian cities and the potentials for improving the recycling of manure and waste nutrients from urban 
to rural areas. Such information will be crucial for the development of recommendations and guidelines for nutrient management strategies for farms in urban regions.

\subsection{Research questions, hypotheses and objectives}

The main research questions of my thesis are:

1. What are the main UPA farm types in different cities and what are the environmental (nutrient balances) and socioeconomic (income) performances of the farm types?

2. What are the possible impacts of recycling urban livestock manure and waste nutrients on fertilizer savings, environmental pollutions, and nutrient use efficiency at system levels in urban, peri-urban and rural areas?

Although 14 different macro and micro nutrients are essential for plant growth and development and 22 for animal growth and development (White and Brown, 2010), I focused on $\mathrm{N}, \mathrm{P}$ and $\mathrm{K}$, because these are the primary macro nutrients required in large quantities by agricultural crops and are mostly known to limit crop productivity (Razaq et al., 2017; White and Brown, 2010). Many soils in SSA are affected by multiple nutrient deficiencies including $\mathrm{N}, \mathrm{P}$ and $\mathrm{K}$ (de Valença et al., 2017). Alike, deficiency of secondary nutrients ( $\mathrm{S}, \mathrm{Ca}$ and $\mathrm{Mg}$ ) and micro nutrients $(\mathrm{Zn}, \mathrm{Fe}, \mathrm{Cu}, \mathrm{Mn}, \mathrm{Mo}$ and $\mathrm{B})$ may also retard the growth and development of crops and animals including humans (de Valença et al., 2017). Deficiencies of micronutrients may also limit the nutritional quality of foods and thereby human nutrition and health (Kihara et al., 2020). I do realize that organic manures and wastes contain essential nutrients and their N, P and $\mathrm{K}$ contents may be used also as proxies for secondary nutrients and micronutrients.

The general hypotheses of my thesis research are:

- H1: Nutrient balances and economic performances of UPA farms are related to specific farm characteristics, which can be understood through systematic inventories and classification of UPA farm types;

- H2: The relative allocation of nutrients to crop and livestock compartments in mixed crop-livestock farms, expressed as crop-livestock ratio determines the performances of the farms;

- H3: Improved recycling and reuse of urban nutrient resources greatly decreases the losses of nutrients from urban livestock farms into the wider urban environment and reduces the demand for synthetic fertilizers.

The general objective of my study is to increase the insights on the diversity, characteristics and nutrient balances of UPA farms, and on the quantitative potentials of recycling urban livestock manure and waste nutrients in urban, peri-urban and rural crop farms, for closing the urban-rural nutrient loops in Ethiopia. The specific objectives are:

$>$ To systematically classify the diverse UPA systems in farm typologies and quantify nutrient flows and balances of the identified UPA typologies, 
$>$ To analyze nutrient allocation and recycling between crop and livestock compartments in mixed crop-livestock farms,

$>$ To quantify the potentials of recycling urban livestock manures and wastes from urban city centers to the urban peripheries, peri-urban and rural areas within feasible distances, in three main city regions of Ethiopia,

$>$ To explore various scenarios for improved recycling of urban livestock manures and wastes in urban, peri-urban and rural crop farms for the year 2050, and to test the agronomic and economic effects of 5 types of urban livestock manures and kitchen wastes composts on wheat in peri-urban settings.

\subsection{Outline of this thesis}

My thesis consists of a general introduction, four research chapters and a general discussion, as follows.

Chapter 1 describes the background, research questions and the objectives of my research.

Chapter 2 describes the diversity and nutrient balances of UPA farms in Addis Ababa, Adama and Jimma in Ethiopia.

Chapter 3 reports on the importance of nitrogen allocation and recycling in peri-urban mixed crop-livestock farms in Ethiopia, in terms of partial nitrogen balance, nitrogen use efficiency, nitrogen recycling index and net farm income.

Chapter 4 estimates the nutrients $(\mathrm{N}, \mathrm{P}$ and $\mathrm{K})$ recycling in manure from urban livestock farms to the proximate crop farms in urban, peri-urban and rural areas for closing the urban-rural nutrient loops. The strategies of manure allocation between the crop farms in urban, peri-urban and rural areas and the mechanism to characterize the allocation are also indicated.

Chapter 5 reports on scenarios for recycling urban livestock manure and waste in rural areas in Jimma for the year 2050. It includes results of a field experiment aimed at deriving the nitrogen fertilizer replacement values of the composts, to be used in the model simulations and scenario analyses.

Chapter 6 discusses and integrates the results of the preceding chapters. Options of recycling urban livestock manures and wastes to crop farms in urban, peri-urban and rural areas for closing the urban-rural nutrient loops in Ethiopia are indicated.

Chapters 2, 3 and 4 have been published in peer reviewed journals. Chapter 5 has been accepted in revised form. All the key methods, data, and results are presented in the Chapters.

I have used three main research methodologies (Figure 1.3):

(i) Surveys and interviews, 
(ii) Modelling and monitoring,

(iii) Scenario analysis and targeted field experiments.

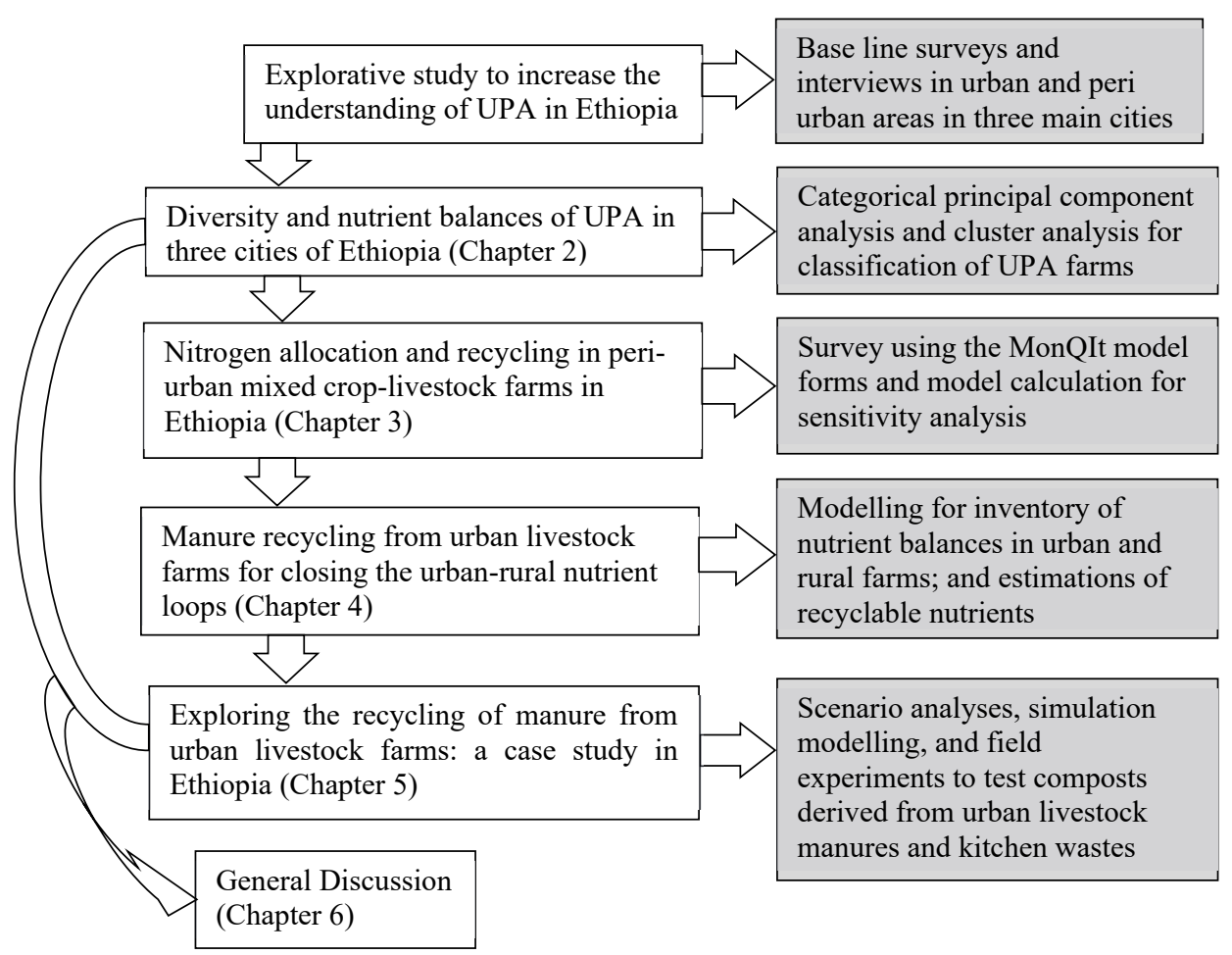

Figure 1.3 Description of research methodologies used in my study. The white boxes on the left show the description of the chapters and the shaded boxes on the right depict the methodologies and accompanied tools used to achieve the objectives of the chapters.

NOTE: MonQIt (Monitoring for Quality Improvement toolbox) is a tool for monitoring and evaluating the management and performances of smallholder farms (www.monqit.com). The information about farm management and farm activities is obtained from the farmer using the MonQIt questionnaire. MonQIt model contains a data base with information on nutrient contents of products, soil data and conversion factors and then produces the following performance indicators: NPK balances at plot, activity and farm levels, and gross margin and net farm income (van Beek et al., 2016). 


\section{Chapter 1}

\section{References:}

Abdulkadir A., Leffelaar P.A., Agbenin J.O., Giller K.E. (2013) Nutrient flows and balances in urban and peri-urban agroecosystems of Kano, Nigeria. Nutrient Cycling in Agroecosystems 95:231-254.

Abu Hatab A., Cavinato M.E.R., Lindemer A., Lagerkvist C.-J. (2019) Urban sprawl, food security and agricultural systems in developing countries: A systematic review of the literature. Cities 94:129-142.

Akram U., Quttineh N.H., Wennergren U., Tonderski K., Metson G.S. (2019) Enhancing nutrient recycling from excreta to meet crop nutrient needs in Sweden - a spatial analysis. Sci Rep 9:10264.

Barthel S., Isendahl C., Vis B.N., Drescher A., Evans D.L., van Timmeren A. (2019) Global urbanization and food production in direct competition for land: Leverage places to mitigate impacts on SDG2 and on the Earth System. The Anthropocene Review 6:7197.

Bon H., Parrot L., Moustier P. (2010) Sustainable urban agriculture in developing countries. A review. Agronomy for Sustainable Development 30:21-32.

Bren d'Amour C., Reitsma F., Baiocchi G., Barthel S., Guneralp B., Erb K.H., Haberl H., Creutzig F., Seto K.C. (2017) Future urban land expansion and implications for global croplands. Proc Natl Acad Sci USA 114:8939-8944.

Castillo G.E. (2003) Livelihoods and the city: an overview of the emergence of agriculture in urban spaces. Progress in Development Studies 3:339-344.

Chianu J.N., Chianu J.N., Mairura F. (2011) Mineral fertilizers in the farming systems of subSaharan Africa. A review. Agronomy for Sustainable Development 32:545-566.

Cobo J.G., Dercon G., Cadisch G. (2010) Nutrient balances in African land use systems across different spatial scales: A review of approaches, challenges and progress. Agriculture, Ecosystems \& Environment 136:1-15.

de Boer I.J.M., van Ittersum M.K. (2018) Circularity in agricultural production.

de Valença A.W., Bake A., Brouwer I.D., Giller K.E. (2017) Agronomic biofortification of crops to fight hidden hunger in sub-Saharan Africa. Global Food Security 12:8-14.

Dehinenet G., Mekonnen H., Kidoido M., Ashenafi M., Bleich E.G. (2014) Factors influencing adoption of dairy technology on small holder dairy farmers in selected zones of Amhara and Oromia National Regional States, Ethiopia. Discourse Journal of Agriculture and Food Sciences 2:126-135.

Drechsel P., Gyiele L., Kunze D., Cofie O. (2001a) Population density, soil nutrient depletion, and economic growth in sub-Saharan Africa. Ecological Economics 38:251-258.

Drechsel P., Kunze D., Vries F.P.d. (2001b) Soil Nutrient Depletion and Population Growth in Sub-Saharan Africa: A Malthusian Nexus? Population and Environment: A Journal of Interdisciplinary Studies 22:411-423.

Eigenbrod C., Gruda N. (2014) Urban vegetable for food security in cities. A review. Agronomy for Sustainable Development 35:483-498. 
Godfray H.C., Crute I.R., Haddad L., Lawrence D., Muir J.F., Nisbett N., Pretty J., Robinson S., Toulmin C., Whiteley R. (2010) The future of the global food system. Philos Trans R Soc Lond B Biol Sci 365:2769-77.

Goulding K., Jarvis S., Whitmore A. (2008) Optimizing nutrient management for farm systems. Philos Trans R Soc Lond B Biol Sci 363:667-80.

Grote U., Craswell E., Vlek P. (2005) Nutrient flows in international trade: Ecology and policy issues. Environmental Science \& Policy 8:439-451.

Hailu H., Mamo T., Keskinen R., Karltun E., Gebrekidan H., Bekele T. (2015) Soil fertility status and wheat nutrient content in Vertisol cropping systems of central highlands of Ethiopia. Agriculture \& Food Security 4:1-10.

Jones D.L., Cross P., Withers P.J.A., DeLuca T.H., Robinson D.A., Quilliam R.S., Harris I.M., Chadwick D.R., Edwards-Jones G., Kardol P. (2013) REVIEW: Nutrient stripping: the global disparity between food security and soil nutrient stocks. Journal of Applied Ecology 50:851-862.

Jurgilevich A., Birge T., Kentala-Lehtonen J., Korhonen-Kurki K., Pietikäinen J., Saikku L., Schösler H. (2016) Transition towards Circular Economy in the Food System. Sustainability 8 .

Khumalo N., Sibanda M. (2019) Does Urban and Peri-Urban Agriculture Contribute to Household Food Security? An Assessment of the Food Security Status of Households in Tongaat, eThekwini Municipality. Sustainability 11.

Kiboi N.M., Ngetich K.F., Mugendi N.D. (2019) Nitrogen budgets and flows in African smallholder farming systems. AIMS Agriculture and Food 4:429-446.

Kihara J., Bolo P., Kinyua M., Rurinda J., Piikki K. (2020) Micronutrient deficiencies in African soils and the human nutritional nexus: opportunities with staple crops. Environ Geochem Health.

Korhonen J., Nuur C., Feldmann A., Birkie S.E. (2018) Circular economy as an essentially contested concept. Journal of Cleaner Production 175:544-552.

Korir S., Rotich K., Mining P. (2015) Urban agriculture and food security in developing countries: a case study of eldoret municipality, kenya. European Journal of Basic and Applied Sciences 2.

Krause A., Rotter V. (2018) Recycling Improves Soil Fertility Management in Smallholdings in Tanzania. Agriculture 8.

Kwasi A.A. (2010) Urban and Peri-Urban Agriculture in Developing Countries Studied using Remote Sensing and In Situ Methods. Remote Sensing 2:497-513.

Landis D.A. (2017) Designing agricultural landscapes for biodiversity-based ecosystem services. Basic and Applied Ecology 18:1-12.

Lerner A.M., Eakin H. (2011) An obsolete dichotomy? Rethinking the rural-urban interface in terms of food security and production in the global south. The Geographical Journal 177:311-320.

Lesschen J.P., Stoorvogel J.J., Smaling E.M.A., Heuvelink G.B.M., Veldkamp A. (2007) A spatially explicit methodology to quantify soil nutrient balances and their uncertainties at the national level. Nutrient Cycling in Agroecosystems 78:111-131. 
Ma L., Guo J., Velthof G.L., Li Y., Chen Q., Ma W., Oenema O., Zhang F. (2014) Impacts of urban expansion on nitrogen and phosphorus flows in the food system of Beijing from 1978 to 2008. Global Environmental Change 28:192-204.

MacDonald G.K., Bennett E.M., Potter P.A., Ramankutty N. (2011) Agronomic phosphorus imbalances across the world's croplands. Proc Natl Acad Sci USA 108:3086-91.

Matsumoto N., Paisancharoen K., Ando S. (2009) Effects of changes in agricultural activities on the nitrogen cycle in Khon Kaen Province, Thailand between 1990-1992 and 20002002. Nutrient Cycling in Agroecosystems 86:79-103.

Monney I. (2013) Urbanization and Pollution of Surface Water Resources in the Two Largest Cities in Ghana. International Journal of Environmental Monitoring and Analysis 1.

Mpofu T. (2013) An evaluation of the performance of urban agriculture in Addis-Ababa City, Ethiopia. Res. J. Agric. Environ. Manage. 2:51-57.

Mulugeta M. (2013) The Need for Policy Framework for Urban/Peri-Urban Agriculture in Ethiopia: A Reflection. EJOSSAH 9:79-109.

Mylan J., Holmes H., Paddock J. (2016) Re-Introducing Consumption to the 'Circular Economy': A Sociotechnical Analysis of Domestic Food Provisioning. Sustainability 8.

Nigussie A., Kuyper T., de Neergaard A. (2015) Agricultural waste utilisation strategies and demand for urban waste compost: Evidence from smallholder farmers in Ethiopia. Waste Manag 44:82-93.

Orsini F., Kahane R., Nono-Womdim R., Gianquinto G. (2013) Urban agriculture in the developing world: a review. Agronomy for Sustainable Development 33:695-720.

Ovsthus I., Seljasen R., Stockdale E., Uhlig C., Torp T., Breland T.A. (2017) Yield, nitrogen recovery efficiency and quality of vegetables grown with organic waste-derived fertilisers. Nutrient Cycling in Agroecosystems 109:233-248.

Potter P., Ramankutty N., Bennett E.M., Donner S.D. (2010) Characterizing the Spatial Patterns of Global Fertilizer Application and Manure Production. Earth Interactions 14:1-22.

Razaq M., Zhang P., Shen H.L., Salahuddin. (2017) Influence of nitrogen and phosphorous on the growth and root morphology of Acer mono. PLoS One 12:e171321.

Satterthwaite D., McGranahan G., Tacoli C. (2010) Urbanization and its implications for food and farming. Philos Trans R Soc Lond B Biol Sci 365:2809-20.

Shah F., Wu W. (2019) Soil and Crop Management Strategies to Ensure Higher Crop Productivity within Sustainable Environments. Sustainability 11.

Szabo S. (2015) Urbanisation and Food Insecurity Risks: Assessing the Role of Human Development. Oxford Development Studies 44:28-48.

Tittonell P., Giller K.E. (2013) When yield gaps are poverty traps: The paradigm of ecological intensification in African smallholder agriculture. Field Crops Research 143:76-90.

Tittonell P., Vanlauwe B., Leffelaar P.A., Rowe E.C., Giller K.E. (2005) Exploring diversity in soil fertility management of smallholder farms in western Kenya. Agriculture, Ecosystems \& Environment 110:149-165.

Toop T.A., Ward S., Oldfield T., Hull M., Kirby M.E., Theodorou M.K. (2017) AgroCycle developing a circular economy in agriculture. Energy Procedia 123:76-80. 
Ugboh O., Ulebor J. (2011) Application of integrated soil fertility approach in the improvement of soil fertility in semi-arid ecology. Journal of Agriculture and Social Research (JASR) 11:81-86.

van Beek C.L., Elias E., Yihenew G.S., Heesmans H., Tsegaye A., Feyisa H., Tolla M., Melmuye M., Gebremeskel Y., Mengist S. (2016) Soil nutrient balances under diverse agro-ecological settings in Ethiopia. Nutrient Cycling in Agroecosystems 106:257-274.

Van Zanten H.H.E., Herrero M., Van Hal O., Roos E., Muller A., Garnett T., Gerber P.J., Schader C., De Boer I.J.M. (2018) Defining a land boundary for sustainable livestock consumption. Glob Chang Biol 24:4185-4194.

White P.J., Brown P.H. (2010) Plant nutrition for sustainable development and global health. Ann Bot 105:1073-80.

Wilhelm J.A., Smith R.G. (2017) Ecosystem services and land sparing potential of urban and peri-urban agriculture: A review. Renewable Agriculture and Food Systems 33:481494.

Yu C., Xiao Y., Ni S. (2017) Changing patterns of urban-rural nutrient flows in China: driving forces and options. Science Bulletin 62:83-91.

Zezza A., Tasciotti L. (2010) Urban agriculture, poverty, and food security: Empirical evidence from a sample of developing countries. Food Policy 35:265-273.

Zhu Y.G., Reid B.J., Meharg A.A., Banwart S.A., Fu B.J. (2017) Optimizing Peri-URban Ecosystems (PURE) to re-couple urban-rural symbiosis. Sci Total Environ 586:10851090.

Zingore B.S., Mutegi J., Agesa B., Tamene L., Kihara J. (2015) Soil Degradation in subSaharan Africa and Crop Production Options for Soil Rehabilitation. Better Crops 99. 


\section{CHAPTER 2}

\section{Diversity and nutrient balances of urban and peri-urban farms in Ethiopia}

This chapter is published as:

Tadesse ST, Oenema O, Van Beek C, Ocho FL (2018) Diversity and nutrient balances of urban and peri-urban farms in Ethiopia. Nutr Cycl Agroecosyst 111:1-18. doi.org/10.1007/s10705-018-9911-0. Supplementary information is found in the link https://static-content.springer.com/esm/art\%3A10.1007\%2Fs10705-018-99110/MediaObjects/10705_2018_9911_MOESM1_ESM.pdf. 


\begin{abstract}
Urban and peri-urban agriculture (UPA) is important for food security in fast growing cities of developing countries. UPA also may have an important role in nutrient recycling at the interface of rural and urban areas. However, little is known about this role and whether it is different for different UPA systems. Here, we report on diversity and nutrient balances of UPA systems in three main cities of Ethiopia. Data collected from 425 households (Addis Ababa: 175, Adama: 126, Jimma: 124) were subjected to categorical principal component analysis and cluster analysis to classify the households. Four farm types per city and overall six: commercial livestock (cLS), commercial vegetable crop (cVC), subsistence field crop (sFC), cLScVC, cLScVCsFC and sVCsFC were identified across the three cities. Two types, cLS and cLScVC were common to the three cities. The farm types differed in resource endowment, income, soil fertility management and nutrient balances. cLS systems accumulated 450, 85 and $260 \mathrm{~kg} \mathrm{~N}$, $\mathrm{P}$ and $\mathrm{K} \mathrm{ha}^{-1}$ year $^{-1}$ and had $26 \% \mathrm{~N}$ and $\mathrm{P}$ and $15 \% \mathrm{~K}$ use efficiency, respectively while $\mathrm{sFC}$ systems depleted $-30 \mathrm{~kg} \mathrm{~N}$ and $-17 \mathrm{~kg} \mathrm{~K} \mathrm{ha}^{-1}$ year $^{-1}$ and had $155 \% \mathrm{~N}$ and $>100 \% \mathrm{~K}$ use efficiency. There was little exchange of manure and crop residue between LS, FC and VC systems. To use the potential role of UPA in nutrient recycling, a directive that imposes LS systems to distribute their surplus manure resources to proximate $\mathrm{FC}$ and $\mathrm{VC}$ systems and improve their nutrient use efficiency should be put in place.
\end{abstract}

Key words: Urbanization; agriculture; farm management; soil fertility; farm income 


\subsection{Introduction}

Urbanization is one of the major social changes sweeping the globe (Akhmat and Bochun, 2010) and currently, over half of the world's population lives in urban areas (Floater et al., 2014). Much of the current urbanization takes place in Africa and Asia, where urbanization started later compared to Europe and America (David et al., 2010). It leads to conversion of natural landscape into urban area, intensifies competition between land users and withdraws soil resources needed for food production (Blum, 1997). The situation is particularly pervasive in some developing countries in Sub Saharan Africa (SSA) (FAO, 2011; Makita et al., 2010), because most urban centers expand over their nations' most productive land (David et al., 2010). According to several projections, half of the population of Africa and Asia will live in urban areas by 2030 (Chen, 2007). Among the rapidly developing countries, Ethiopia is the second populous country in Africa after Nigeria (UN, 2015). In 2015, 20\% of its population was living in urban areas. Its urban population growth is estimated at $6 \%$ a year (Haregewoin, 2005), much higher than most African countries. Consequently, there is an increase in urban food demand that opened a door for farming in and around cities often called urban and periurban agriculture (UPA) (De Bon et al., 2010). Farmers use the advantages of available open spaces and market proximity (Zezza and Tasciotti, 2010). UPA usually focuses on high value and perishable produce (Makita et al., 2010). It contributes to the livelihood of urban dwellers, providing jobs, food and income (Pearson et al., 2010). In Addis Ababa alone it supports the lives of over 51,000 families directly (Firdissa et al., 2007).

The sustainability of the UPA systems depends on their ability of producing healthy and safe food at affordable price while minimally affecting the environment (Nugent, 2001). Currently, it is difficult to articulate strategies for UPA systems improvement because of its diversity and largely unknown socioeconomic and environmental performances (Chatterjee et al., 2015). Thus, data is needed on farm types and nutrient balances of UPA systems (Pacini et al., 2014). Here, we report on farm types and nutrient balances of UPA systems in three main cities of Ethiopia.

\subsection{Materials and methods}

\subsubsection{Study sites}

Three main cities in Ethiopia, Addis Ababa, Adama and Jimma were selected for this study (Figure 2.1). They have a total population of 3.1, 0.3 and 0.2 million, and a population growth rate of 3.8, 4.5 and 3.0\% per year, respectively (Haile Mariam and Adugna, 2011). Addis Ababa $\left(9^{\circ} 1^{\prime} 48^{\prime \prime} \mathrm{N}, 38^{\circ} 44^{\prime} 24^{\prime \prime} \mathrm{E}\right)$ is the capital city of the country. It is situated at an altitude of 2,300 3,000 m.a.s.1. Minimum and maximum daily temperatures are 10.7 and $23{ }^{\circ} \mathrm{C}$, respectively, and mean annual rain fall is $1165 \mathrm{~mm}$. Barley, wheat and pulses are the staple crops. Adama $\left(8.54^{\circ} \mathrm{N}, 39.27^{\circ} \mathrm{E}\right)$ is the commercial centre near the main port. It is situated at an altitude of 1700 m.a.s.1. Minimum and maximum daily temperatures are 13.3 and $27.8^{\circ} \mathrm{C}$, respectively, and mean annual rainfall is $809 \mathrm{~mm}$. Wheat, barley, teff and pulses are the common crops. 


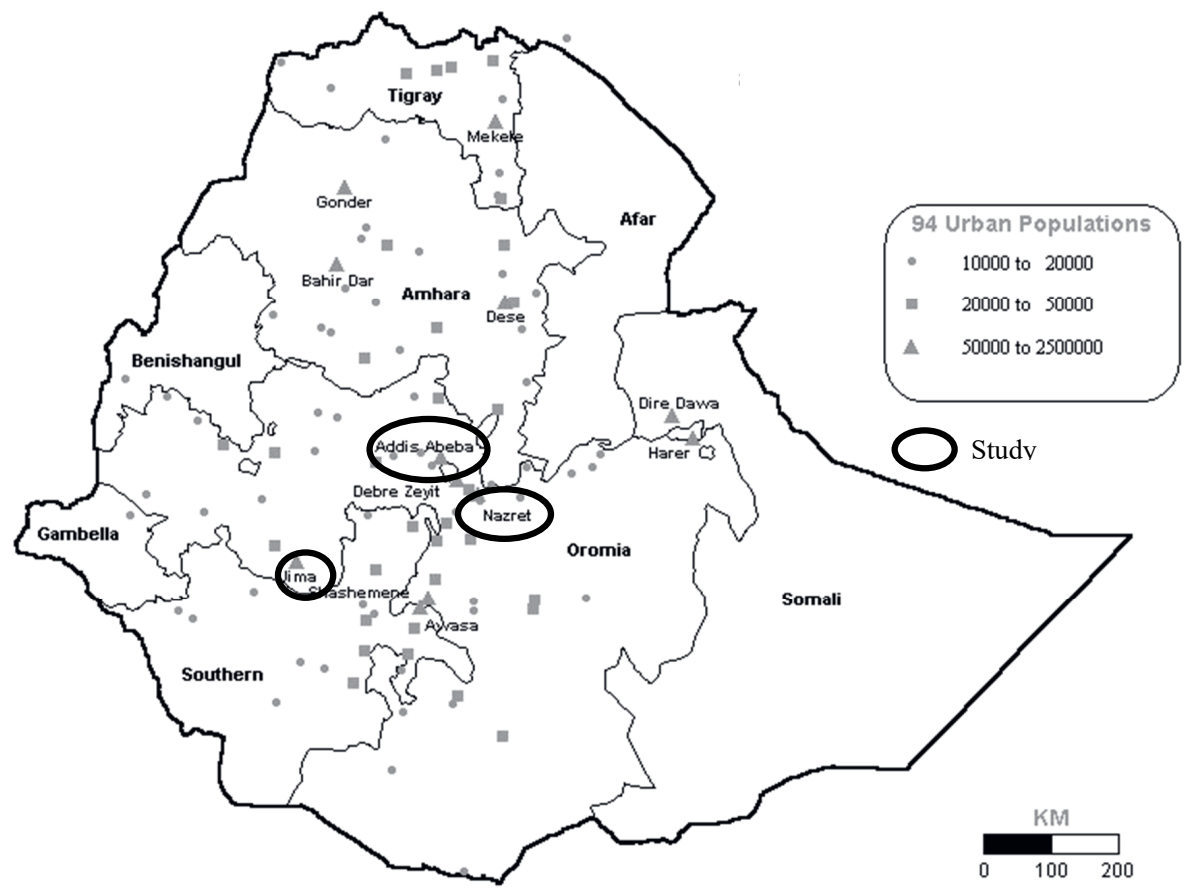

Figure 2.1 Map of major urban areas in Ethiopia, including the study areas Addis Ababa (Finfinne), Nazret (Adama) and Jimma with high population (50,000 to 2,500,000).

Jimma $\left(7^{\circ} 40^{\prime} \mathrm{N}, 36^{\circ} 50^{\prime} \mathrm{E}\right)$ is the commercial centre of Southwestern Ethiopia. It is situated at an altitude of 1780 m.a.s.l. Minimum and maximum daily temperatures are 12 and $27{ }^{\circ} \mathrm{C}$, respectively, and mean annual rainfall is $1510 \mathrm{~mm}$. Coffee, tea, spices, teff and maize are the main crops. According to the information of the city administration, Addis Ababa has ten subcities. The majority of UPA farms are found in five sub-cities: Akaki-Kaliti, Bole, Kirkos, Kolfe-Keranio and Nifasilk-Lafto and were selected for this study. In Adama and Jimma all the districts were selected.

\subsubsection{Data collection}

UPA households were selected through the snowball sampling technique (Dossa et al., 2011). According to Israel (1992), a sample size of 200 is appropriate for farmers' population between 5,000 and 10,000 at 95\% confidence level and 7\% precision level. The current UPA farmers' populations of Addis Ababa, Adama and Jimma are estimated between 1000 and 9000 according to the information obtained from the cities urban agriculture offices. Thus, to get representative data of the main agricultural activities, 175 households in Addis Ababa (64 livestock oriented, 61 vegetable oriented and 50 field crop oriented farmers), 126 in Adama 
(56 livestock, 36 vegetable and 34 field crop farmers) and 124 in Jimma (53 livestock, 34 vegetable and 37 field crop farmers) were interviewed using a structured questionnaire. Prior to the actual survey, a draft version was tested on 15 households and revised subsequently. The questionnaire contained questions such as the socioeconomic characteristics; agricultural practices; resource endowment; use of own agricultural waste, types and quantities of inputs and outputs flows and finally constraints of UPA farms (see supplementary information). The interviews were conducted by four $\mathrm{PhD}$ students of Addis Ababa University and four MSc students of Jimma University between March and August 2014. The students are native to the area and spoke the local language. They were trained by the first author for one week.

\subsubsection{Quantification of partial nutrient balances and nutrient use efficiencies}

Partial nutrient balances of farms result from processes and flows managed by the farmer and are calculated as the net differences of the main easily manageable nutrient inputs (fertilizers and feed) and outputs (farm products) flows (Abdulkadir et al., 2013; van Beek et al., 2016). For increasing the precision in the quantification of the partial nutrient balances, data was collected in two rounds. In round one, input flows (mineral fertilizers, organic fertilizers, purchased seeds, organic feed and concentrates) were quantified by asking the farmer about the use of these inputs at the begining of the season. In the second round, output flows (crop products, residues and animal products) leaving the farm were quantified by asking the farmer after harvest, at the end of the growing season. Estimates of animal manure production were based on information provided by the farmer and additional literature data (Jackson and Mtengeti 2005). The quantity of manure produced by each livestock species (cattle, sheep and goat) was estimated using daily dry matter and nitrogen, phosphorus and potassium production rates per tropical livestock unit, for each of the species. For commercial livestock farms we assumed $100 \%$ recovery of the total manure produced, since the animals are entirely kept in the stable, but for subsistance livestock we assumed $43 \%$ of the manure is recovered in the stable and 57\% was lost outside the farm during grazing. For grazing animals, the feed intake during grazing was considered to balance the loss of manure and urine outside the farm during grazing (Abdulkadir et al. 2013). Data on the nutrient (N, P, K) contents of harvested crop products, crop residues, milk and manure were obtained from literature (Alvarez et al., 2014; Wang et al., 2016). For quantification of nitrogen (N), phosphorus (P) and potassium (K) input and output flows, the mass of inputs and outputs were multiplied by their dry matter contents and N, P, K contents (Bekunda and Manzi, 2003), (Eq. 2.1).

$$
F=\sum_{i=1}^{n} Q i D i C i
$$

Where, $\mathrm{F}$ is the quantity of input or output flows of $\mathrm{N}$ or $\mathrm{P}$ or $\mathrm{K}$ for one year; $\mathrm{n}$ is the number of nutrient inputs and outputs in a year; $\mathrm{Q}$ is the quantity of inputs (organic and inorganic) or outputs, obtained from household survey; D is the dry matter content of inputs or outputs; $\mathrm{C}$ is content of $\mathrm{N}$ or $\mathrm{P}$ or $\mathrm{K}$ in inputs or outputs obtained from literature review. Then, partial nutrient balances were calculated as the difference between input and output flows (Eq. 2.2). 


$$
P N B_{F}=\left[\left(I 1_{F}+I 2_{F}\right)-\left(O 1_{F}+O 2_{F}\right)\right]
$$

Where, $\mathrm{PNB}$ is the partial nutrient balance; $\mathrm{F}$ is the nutrient ( $\mathrm{N}$ or $\mathrm{P}$ or $\mathrm{K})$; $\mathrm{I} 1_{\mathrm{F}}$ and $\mathrm{I} 2_{\mathrm{F}}$ are inputs of inorganic (I1) and organic (I2) nutrients (inorganic fertilizer, compost, concentrate, organic feed) and $\mathrm{O}_{\mathrm{F}}$ and $\mathrm{O} 2 \mathrm{~F}$ are nutrients outputs in harvested crop, residue, milk and manure. Finally, nutrient (N, P and K) use efficiencies of farms were calculated according to Wang et al. (2008) by dividing the quantity of nutrient output by input and multplying by 100 (Eq. 2.3).

$$
N U E=\frac{\text { Nutrient output }\left(O 1_{F}+O 2_{F}\right)}{\text { Nutrient input }\left(I 1_{F}+I 2_{F}\right)} * 100
$$

Where, NUE is the nutrient ( $\mathrm{N}, \mathrm{P}$ and $\mathrm{K})$ use efficiency, in \%.

\subsubsection{Data analysis}

Data was checked, cleaned and subjected to Categorical Principal Component Analysis (CATPCA) as the dataset contained mixed variables (nominal, ordinal and metric). CATPCA was used to explore the relationships between variables and reduce large number of variables into smaller number of principal components (Pacini et al., 2014). CATPCA was done using the 23 variables derived from the surveys (Table 2.1). A component is considered reliable, if it contains a minimum of four variables with component loading score $>0.6$, because a variable with the higher loading score on a given component is the most influential variable, and contributing most to the variation accounted for that component (Abdulkadir et al., 2012; Dossa et al., 2011). Using this criterion, two principal components with loading score $>0.6$ were found per city (Table 2.2). Two-step cluster analysis (CA) was used to classify the households into clusters. Before running $\mathrm{CA}$, visual binning procedure was performed to convert continuous variables into nominal variables and reduce the weight of categorical variables which could be higher at the expense of continuous variables (Dossa et al., 2011). Then, two-step cluster analysis was performed using component scores extracted from CATPCA and the variables with component loading score $>0.6$. The number of UPA clusters was fixed for each city using the Bayesian Information Criterion (BIC). A silhouette measure of cluster cohesion and separation, used for measuring the quality of clustering was between 0.6 and 0.7 and showed a good clustering quality (Dossa et al., 2011). Cluster numbers generated from CA were used to identify which household belongs to which cluster, and a cluster name was assigned to each. ANOVA was performed to test the significant differences in resources endowment, income and nutrient balances between UPA clusters per city. Multiple linear regression was conducted using socioeconomic variables versus nutrient balances of main UPA farm types. We used SPSS statistics version 22 for all types of data analysis. 
Table 2.1 Description of farm management and socio-economic variables used in the CATPCA of 175, 126 and 124 UPA households in Addis Ababa, Adama and Jimma, respectively

\begin{tabular}{|c|c|}
\hline Variables & Description and units \\
\hline A_HH & Age of UPA of $\mathrm{HH}^{\mathrm{a}}$ (years) \\
\hline $\mathrm{S}-\mathrm{HH}$ & Sex of HH (female, male) \\
\hline$\overline{\mathrm{ACT}} \mathrm{F}_{-}$ & Active labor force between 15 and 65 (years) \\
\hline F_EXPP & Farming experience of HH in UPA (years) \\
\hline NP_FCVC & $\begin{array}{l}\text { Field crop (FC) and vegetable crop (VC) plots owned by a } \\
\mathrm{HH} \text { (number) }\end{array}$ \\
\hline TLD_SZ & Total land size owned by the $\mathrm{HH}$ (ha) \\
\hline N_DRC & Number of dairy cows (number) \\
\hline TLES_TLU & Total number of livestock production (TLU) ${ }^{\mathrm{b}}$ \\
\hline $\mathrm{INC}_{-}^{-} \mathrm{FC}$ & Income from $\mathrm{FC}(\mathrm{ETB})^{\mathrm{c}}$ \\
\hline $\mathrm{INC}_{-}^{-} \mathrm{VC}$ & Income from VC (ETB) \\
\hline INC_MK & Income from milk (ETB) \\
\hline $\mathrm{INC}_{-}^{-} \mathrm{LS}$ & Income from livestock (LS) (ETB) \\
\hline INC_UPA & Income from urban and peri urban agriculture (ETB) \\
\hline PROB_F & HH primary farming objective (consumption, sales) \\
\hline INV_LS_P & $\mathrm{HH}$ involvement in (peri) urban LS production (yes, no) \\
\hline INV_DR_F & $\mathrm{HH}$ involvement in (peri) urban dairy farming (yes, no) \\
\hline INV_VC_P & $\mathrm{HH}$ involvement in (peri) urban VC production (yes, no) \\
\hline INV_FC_P & $\mathrm{HH}$ involvement in (peri) urban FC production (yes, no) \\
\hline OW_SFM & Use of own waste for soil fertility management (yes, no) \\
\hline VC_SR_INC & Sales of VC as source of income of HH (yes, no) \\
\hline MK_SR_INC & Sale of milk as source of income of HH (yes, no) \\
\hline HCT_IN_FCP & Cost of inputs for FC production (high, medium, low) \\
\hline HCT_FE_LSP & Cost of feed for LS production (high, medium, low) \\
\hline \multicolumn{2}{|c|}{$\begin{array}{l}\text { a } \mathrm{HH}=\text { household head; } \\
{ }^{\mathrm{b}} \mathrm{TLU} \text { : Tropical livestock unit, a hypothetical animal of } 250 \mathrm{~kg} \text { live weight; TLU } \\
\quad \text { conversion factors used: cattle }=0.8 \text {, sheep and goats }=0.1 \text {, donkey }=0.5 \text {, and } \\
\text { poultry }=0.01 \text {, } \\
\text { c Ethiopian Birr }(1000 \mathrm{ETB}=43 \mathrm{US} \$)\end{array}$} \\
\hline
\end{tabular}

\subsection{Results}

\subsubsection{Categorical principal component analysis (CATPCA)}

Two reliable principal components representing the information in the original variables were obtained for each city. The first component accounted for $31 \%$ of variance in Addis Ababa, $34 \%$ in Adama and $40 \%$ in Jimma UPA systems. The second component accounted for $22 \%$, $15 \%$ and $11 \%$ of variances in the UPA systems of the three cities, respectively. The most influential variables with high component loading scores were related to the main UPA activities: livestock (LS), vegetable crops (VC) and field crops (FC) production. For instance, for Addis Ababa UPA, income from VC was strongly related with principal component one, while income from FC and LS was strongly related with principal component two. For Adama, income from $\mathrm{VC}$ was also strongly related with principal component one. In contrast, number 
of LS (TLU) and income from LS was strongly related with principal component one for Jimma. These variables with high loading score $(>0.6)$ on either of the principal components contributed greatly to the variation explained by the component, and they are influencial variables for the classification of the UPA households into clusters. Cronbach's alpha values for both components were high per city (Table 2.2); values above 0.7 indicate high internal consistency of variables and homogeneity of UPA systems per cluster.

Table 2.2 Component loadings of socioeconomic variables used for CATPCA in Addis Ababa, Adama and Jimma cities (Variables are explained in Table 1)

\begin{tabular}{|c|c|c|c|c|c|c|}
\hline \multirow[t]{2}{*}{ Variables } & \multicolumn{2}{|c|}{ Addis Ababa $(\mathrm{n}=175)$} & \multicolumn{2}{|c|}{ Adama $(n=126)$} & \multicolumn{2}{|c|}{$\operatorname{Jimma}(\mathrm{n}=124)$} \\
\hline & 1 & 2 & 1 & 2 & 1 & 2 \\
\hline A_HH ${ }^{a}$ & .328 & .119 & -.388 & .094 & -.203 & .292 \\
\hline $\mathrm{S} \_-\mathrm{HH}$ & .017 & .035 & .296 & -.069 & -.038 & .182 \\
\hline ACT_F & .334 & .087 & -.092 & .034 & -.144 & .286 \\
\hline F_EXP & .162 & -.274 & -.664 & -.199 & 281 & .455 \\
\hline PROB_F & -.148 & .655 & .317 & .458 & -.521 & -.466 \\
\hline INV_LS_P & -.608 & -.481 & -.578 & .111 & .704 & .256 \\
\hline INV_DR_F & -.497 & -.498 & -.296 & .046 & 697 & .230 \\
\hline INV_VC_P & .915 & -.300 & .836 & -.383 & -.664 & .490 \\
\hline INV_FC_P & -.221 & .735 & .783 & .404 & -.737 & -.059 \\
\hline NP_FCVC & -.798 & .302 & -.812 & -.046 & .866 & .076 \\
\hline TLD_SZ & -.082 & -.551 & -.649 & -.361 & .556 & .069 \\
\hline N_DRC & .496 & .575 & .274 & -.035 & -.709 & -.350 \\
\hline TLS_TLU & .511 & .556 & .277 & .237 & -.606 & -.389 \\
\hline OW_SFM & .605 & -.121 & .357 & .289 & -.607 & .026 \\
\hline $\mathrm{INC} F \mathrm{FC}$ & .141 & -.654 & -.326 & -.457 & .471 & -.292 \\
\hline VC_SR_INC & .892 & -.310 & .843 & -.411 & -.648 & .549 \\
\hline INC $V \bar{C}$ & -.684 & .204 & -.719 & .467 & .520 & -.226 \\
\hline MK_SR_INC & -.453 & -.603 & -.428 & -.245 & .813 & .299 \\
\hline INC_MK & .463 & .593 & .395 & .322 & -.646 & -.195 \\
\hline $\mathrm{INC}^{-} \mathrm{LS}$ & .490 & .685 & .426 & .398 & -.685 & -.188 \\
\hline INC_UPA & .437 & .582 & .202 & .501 & -.685 & -.188 \\
\hline HCT_IN_FCP & .293 & .345 & .558 & .380 & -.710 & .081 \\
\hline HCT_FE_LSP & -.426 & -.389 & -.323 & .220 & 692 & .172 \\
\hline Cronbach's Alpha & 0.93 & 0.88 & 0.94 & 0.81 & 0.95 & 0.72 \\
\hline Total Eigenvalue & 9.76 & 6.74 & 10.60 & 4.55 & 12.67 & 3.29 \\
\hline Total $\%$ of variance & 31.49 & 21.74 & 34.21 & 14.68 & 40.86 & 10.61 \\
\hline
\end{tabular}

${ }^{\mathrm{a} H H}=$ Household head

Vectors pointing in the same direction in Figure 2.2 were correlated and their length indicated that they are the most influential variables. High Eigenvalues of component one and two in Table 2.2 indicated, large percentage of variance was explained by the components. 

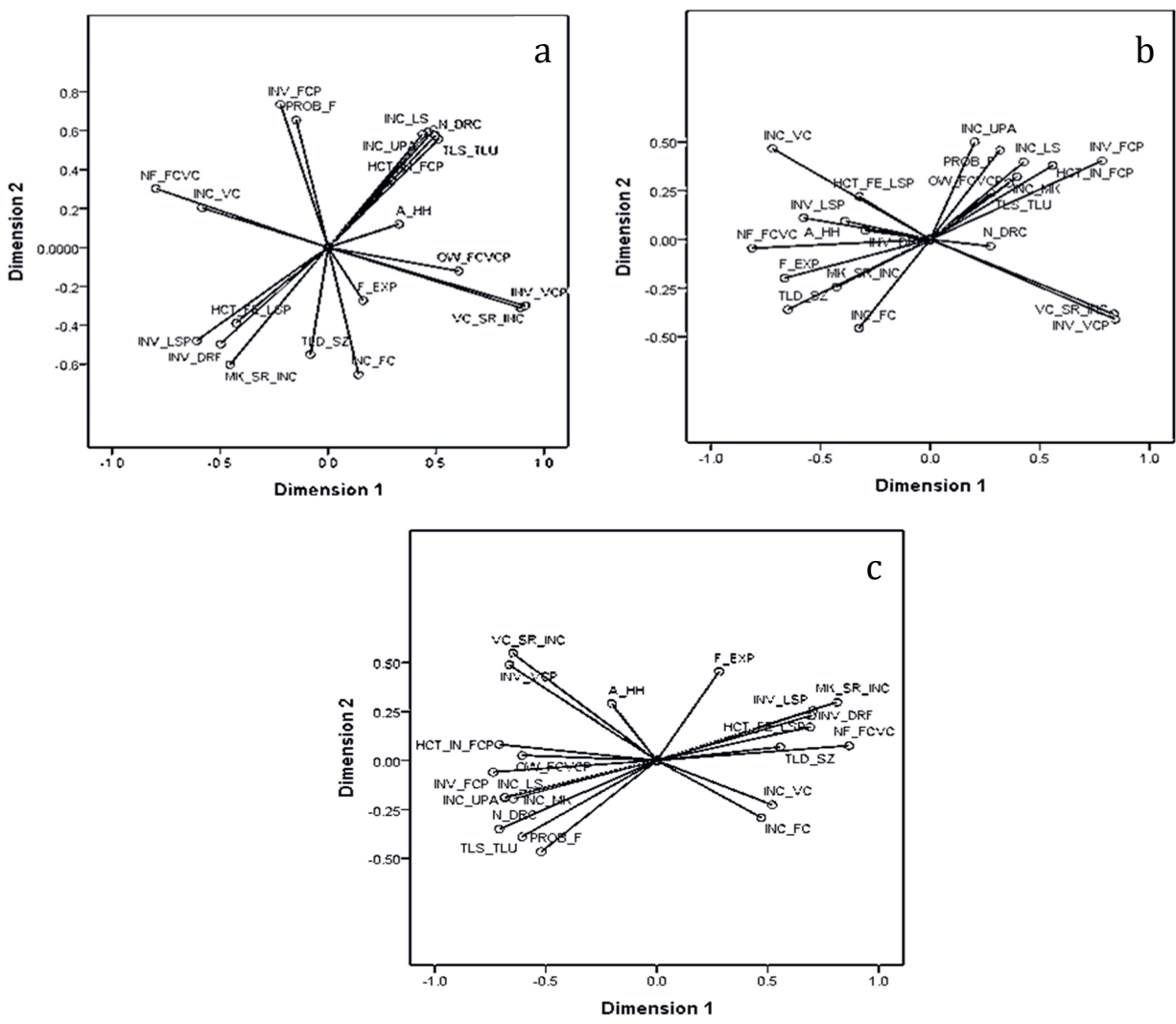

Figure 2.2 Plots of component loadings for (a) Addis Ababa $(n=175)$, (b) Adama $(n=126)$ and (c) Jimma $(n=124)$ UPA depicting the relationship among most influential variables described in Table 1 and 2.

\subsubsection{Classification of UPA households}

Two-step cluster analysis yielded four distinct farm types per each city. Due to similarities of some farm types between the cities, six different farm types were distinguished across the cities of Addis Ababa, Adama and Jimma in Ethiopia (Table 2.3). Among these, subsistence field crop farm ( $\mathrm{sFC}$ ) was common to Addis Ababa and Adama, and mixed commercial livestock and vegetable crop and subsistence field crop (cLScVCsFC) was common to Adama and Jimma. Two farm types, commercial livestock (cLS) and commercial livestock and vegetable crop (cLScVC) were common to the three cities but commercial vegetable crop farm (cVC) was unique to Addis Ababa while subsistence vegetable crop and field crop (sVCsFC) was unique to Jimma. Farms are categorized as commercial or subsistence based on their primary farming objective (Table 2.4). 
Table 2.3 Classification of UPA farms and the distribution of households $(\mathrm{HH})$ across the four clusters at Addis Ababa, Adama and Jimma

\begin{tabular}{|c|c|c|c|c|c|c|}
\hline \multirow[t]{2}{*}{ Clusters of UPA } & \multicolumn{2}{|c|}{ Addis Ababa $(\mathrm{n}=175)$} & \multicolumn{2}{|c|}{ Adama $(n=126)$} & \multicolumn{2}{|c|}{ Jimma $(n=124)$} \\
\hline & Cluster Name & $\% \mathrm{HH}$ & Cluster Name & $\% \mathrm{HH}$ & Cluster Name & $\% \mathrm{HH}$ \\
\hline Cluster 1 (one) & cLS & 36 & cLS & 28 & $\mathrm{sVCsFC}$ & 28 \\
\hline Cluster 2 (two) & sFCsLS & 22 & cLScVC & 22 & cLScVCsFC & 22 \\
\hline Cluster 3 (three) & cLScVCsFC & 15 & sFCsLS & 26 & cLScVC & 10 \\
\hline Cluster 4 (four) & $\mathrm{cVCsFC}$ & 27 & cLScVCsFC & 24 & cLS & 40 \\
\hline
\end{tabular}

cLS = commercial livestock farms; sFCsLS = subsistence field crop and subsistence livestock farms; $\mathrm{cVCsFC}=$ commercial vegetable and subsistence field crop farms; $\mathrm{cLScVC}=$ commercial livestock and commercial vegetable crop farms; $\mathrm{sVCsFC}=$ subsistence vegetable crop and subsistence field crop farms; cLScVCsFC = commercial livestock, commercial vegetable crop and subsistence field crop farms

\subsubsection{1 cLS: Cluster one at Addis Ababa and Adama and cluster four at Jimma UPA}

This farm type is categorized as commercial livestock (cLS), because the primary farming objective was marketing for $100 \%$ farms in cluster 1 at Addis Ababa, $86 \%$ in cluster 1 at Adama and $100 \%$ in cluster 4 at Jimma (Table 2.4). Farms in this cluster are located in urban residential areas. cLS is done by $36 \%$ of farmers interviewed at Addis Ababa, $28 \%$ at Adama and $40 \%$ at Jimma (Table 2.3). It is the most important economic activity with the highest income across the cities (Table 2.5).

\subsubsection{2 cLScVC: Cluster two at Adama and cluster three at Jimma UPA}

This farm type is categorized as commercial livestock and vegetable crop (cLScVC), as the primary farming objective was marketing for $100 \%$ of the farms in cluster 3 at Addis Ababa and Jimma and for $79 \%$ farms in cluster 2 at Adama. At Addis Ababa 100\% of cLScVC farms were involved in LS and $96 \%$ in VC production (Table 2.4). cLS farms were located in the urban areas and $\mathrm{cVC}$ farms were located in urban and peri-urban areas near rivers. cLScVC farming is done by $15 \%$ of households interviewed at Addis Ababa, 22\% at Adama and 10\% at Jimma (Table 2.3).

\subsubsection{3 cLScVCsFC: Cluster three at Addis Ababa, four at Adama and two at Jimma UPA}

Marketing was the primary farming objective for 63 and $67 \%$ of the farmers in cluster 4 at Adama and cluster 2 at Jimma. It is located in urban and per-urban areas and done by $24 \%$ of the farmers at Adama and 22\% at Jimma (Table 2.3). At Adama, $57 \%$ of the cLScVCsFC farms were involved in both LS and VC and 91\% in FC production in cluster 4 (Table 2.4).

\subsubsection{4 cVC: Cluster four at Addis Ababa UPA}

This farm type is categorized as commercial vegetable crop farm (cVC), and uniquely identified at Addis Ababa UPA. It is practiced in peri-urban areas by $27 \%$ of the households 
interviewed at Addis Ababa (Table 2.3). Here, 100\% of the cVC farms produce VC for the market (Table 2.4).

\subsubsection{5 sFC: Cluster two at Addis Ababa and cluster three at Adama UPA}

This farm type is categorized as subsistence FC ( $\mathrm{sFC}$ ) farming, as the primary farming objective was consumption for $93 \%$ of the farms in cluster 2 at Addis Ababa and for $65 \%$ of the farms in cluster 3 at Adama. At Addis Ababa 100\% of the sFC farms and at Adama $97 \%$ of the sFC farms produced FC for own consumption (Table 2.4). It is done in peri-urban areas by $22 \%$ of the farmers interviewed at Addis Ababa and by $26 \%$ at Adama (Table 2.3).

\subsubsection{6 sVCsFC: Cluster one at Jimma UPA}

This farm type is identified only at Jimma and categorized as subsistence VC and FC (sVCsFC) farming; home consumption was the primary farming objective for $80 \%$ of the farmers in this cluster. Here, $100 \%$ of the farmers produce FC and $92 \%$ also produce VC (Table 2.4). This farm type is done in peri-urban areas by $28 \%$ of the farmers interviewed at Jimma (Table 2.3).

\subsubsection{Main farm characteristics of UPA clusters across the cities}

UPA clusters had different agricultural waste and fertility management (Table 2.4). At Addis Ababa $100 \%$, at Adama $86 \%$ and at Jimma $92 \%$ of the cLS farmers didn't use their manure for soil fertility management because they didn't produce feed on farm due to shortage of land (Table 2.5). High cost of feed was a constraint for $67 \%$ of the cLS farmers at Addis Ababa, for $62 \%$ at Adama and for $88 \%$ of the cLS farmers at Jimma. Similarly, many sFC farmers (28 to $79 \%$ ) didn't use their crop residues and LS manure for soil fertility management due to competing demand on biomass for feed and fuel. High cost of nutrient inputs was a constraint for 62 to $77 \%$ of the sFC farmers. 
Table 2.4 Distribution of households in percent across the four UPA clusters listed in Table 3 , in terms of the main farm characteristics, at Addis Ababa, Adama and Jimma

\begin{tabular}{|c|c|c|c|c|c|}
\hline \multirow{3}{*}{$\begin{array}{l}\text { Main } \\
\text { farm characteristics }\end{array}$} & \multicolumn{4}{|c|}{ Percentage of households involved } & \multirow[b]{2}{*}{$\chi^{2}$} \\
\hline & $\begin{array}{c}\mathrm{cLS} \\
(\mathrm{n}=63)\end{array}$ & $\begin{array}{r}\text { sFCsLS } \\
(\mathrm{n}=39)\end{array}$ & $\begin{array}{c}\text { cLScVCsFC } \\
(\mathrm{n}=25)\end{array}$ & $\begin{array}{r}\mathrm{cVCsFC} \\
(\mathrm{n}=48)\end{array}$ & \\
\hline & 100 & 7 & 100 & 92 & $* * *$ \\
\hline FC production & 0 & 100 & 20 & 6 & $* * *$ \\
\hline VC production & 0 & 0 & 96 & 100 & $* * *$ \\
\hline LS production & 100 & 36 & 100 & 2 & $* * *$ \\
\hline Use of waste \& residue for SFM, Yes & 0 & 21 & 81 & 56 & $* * *$ \\
\hline No & 100 & 79 & 19 & 44 & $* * *$ \\
\hline High cost of inputs for FC & 0 & 62 & 44 & 42 & $* * *$ \\
\hline High cost of feed for LS & $\begin{array}{c}67 \\
c L S \\
(n=35)\end{array}$ & $\begin{array}{c}10 \\
\mathrm{cLScVC} \\
(\mathrm{n}=28)\end{array}$ & $\begin{array}{c}54 \\
\mathrm{sFCsLS} \\
(\mathrm{n}=33)\end{array}$ & $\begin{array}{c}0 \\
\operatorname{cLScVCsFC} \\
(\mathrm{n}=30)\end{array}$ & $* * *$ \\
\hline Marketing as primary farm objective & 86 & 79 & 35 & 63 & $* * *$ \\
\hline FC production & 0 & 0 & 97 & 91 & **** \\
\hline VC production & 0 & 50 & 0 & 57 & $* * *$ \\
\hline LS production & 100 & 89 & 37 & 57 & $* * *$ \\
\hline Use of waste \& residue for SFM, Yes & 14 & 28 & 43 & 47 & $* * *$ \\
\hline No & 86 & 72 & 57 & 53 & *** \\
\hline High cost of inputs for FC & 0 & 0 & 67 & 60 & $* * *$ \\
\hline High cost of feed for LS & $\begin{array}{c}62 \\
\mathrm{sVCsFC} \\
(\mathrm{n}=35)\end{array}$ & $\begin{array}{c}26 \\
\mathrm{cLScVCsFC} \\
(\mathrm{n}=27)\end{array}$ & $\begin{array}{c}12 \\
\mathrm{cLScVC} \\
(\mathrm{n}=13)\end{array}$ & $\begin{array}{c}23 \\
\mathrm{cLS} \\
(\mathrm{n}=49)\end{array}$ & $* * *$ \\
\hline Marketing as primary farm objective & 20 & 67 & 100 & 100 & $* * *$ \\
\hline FC production & 100 & 77 & 0 & 0 & **** \\
\hline VC production & 92 & 100 & 62 & 0 & $* * *$ \\
\hline LS production & 6 & 52 & 100 & 100 & $* * *$ \\
\hline Use of waste \& residue for SFM, Yes & 72 & 74 & 33 & 8 & *** \\
\hline No & 28 & 26 & 67 & 92 & $* * *$ \\
\hline High cost of inputs for FC & 77 & 67 & 54 & 0 & $* * *$ \\
\hline High cost of feed for LS & 0 & 22 & 69 & 88 & $* * *$ \\
\hline
\end{tabular}

*** Significant at $\mathrm{P}<0.01 ; \chi^{2}$ represents the chi-square values, $\mathrm{SFM}=$ Soil fertility management

There were significant differences among the UPA clusters per city in households' resource endowment and income (Table 2.5). 
Table 2.5 Resource endowment and income of households across the four UPA clusters in Addis Ababa, Adama and Jimma

\begin{tabular}{|c|c|c|c|c|c|}
\hline Addis Ababa & cLS & sFCsLS & cLScVCsFC & $\mathrm{cVCsFC}$ & $\mathrm{P}$ \\
\hline № of UPA farms & 63 & 39 & 25 & 48 & value \\
\hline № of FC and VC fields & $0.38^{\mathrm{c}}$ & $1.13^{\mathrm{b}}$ & $2.04^{\mathrm{a}}$ & $1.71^{\mathrm{a}}$ & $* * *$ \\
\hline Land size (ha) & $0.11^{\mathrm{c}}$ & $1.71^{\mathrm{a}}$ & $0.98^{\mathrm{b}}$ & $0.76^{\mathrm{b}}$ & $* * *$ \\
\hline Livestock (TLU) & $10.4^{\mathrm{a}}$ & $1.74^{\mathrm{c}}$ & $6^{\mathrm{b}}$ & $0.04^{\mathrm{c}}$ & $* * *$ \\
\hline Income from FC (ETB) & 0 & 11951 & 98 & 408 & NS \\
\hline Income from VC (ETB) & 0 & $256^{\mathrm{b}}$ & $23578^{\mathrm{a}}$ & $24856^{\mathrm{a}}$ & $* * *$ \\
\hline Income from LS (ETB) & $172368^{\mathrm{a}}$ & $4779^{c}$ & $74791^{b}$ & 0 & $* * *$ \\
\hline Adama & $\mathrm{cLS}$ & cLScVC & sFCsLS & cLScVCsFC & \\
\hline № of UPA farms & 35 & 28 & 33 & 30 & \\
\hline № of FC and $\mathrm{VC}$ fields & $0.06^{\mathrm{b}}$ & $3.1^{\mathrm{a}}$ & $3.2^{\mathrm{a}}$ & $3.2^{\mathrm{a}}$ & $* * *$ \\
\hline Land size (ha) & $0.03^{\mathrm{c}}$ & $0.9^{\mathrm{b}}$ & $1.5^{\mathrm{a}}$ & $1.1^{\mathrm{b}}$ & $* * *$ \\
\hline Livestock (TLU) & $7.4^{\mathrm{a}}$ & $2^{\mathrm{b}}$ & $3.4^{\mathrm{b}}$ & $3.1^{\mathrm{b}}$ & $* * *$ \\
\hline Income from FC (ETB) & 0 & 0 & $13445^{\mathrm{a}}$ & $5595^{\mathrm{b}}$ & $* * *$ \\
\hline Income from VC (ETB) & 0 & $11744^{\mathrm{b}}$ & $303^{\mathrm{b}}$ & $29522^{\mathrm{a}}$ & $* * *$ \\
\hline \multirow[t]{2}{*}{ Income from LS (ETB) } & $162378^{a}$ & $18037^{\mathrm{b}}$ & $13810^{\mathrm{b}}$ & $16942^{\mathrm{b}}$ & $* *$ \\
\hline & sVCsFC & cLScVCsFC & $\mathrm{cLScVC}$ & cLS & \\
\hline № of UPA farms & 35 & 27 & 13 & 49 & \\
\hline No of FC and $\mathrm{VC}$ fields & $3.8^{\mathrm{a}}$ & $3.1^{\mathrm{a}}$ & $1.9^{\mathrm{b}}$ & $2^{b}$ & $* * *$ \\
\hline Land size (ha) & 1.6 & 1.96 & 0.8 & 0.5 & NS \\
\hline Livestock (TLU) & $0.8^{\mathrm{c}}$ & $3.2^{\mathrm{b}}$ & $3.7^{\mathrm{b}}$ & $8.2^{\mathrm{a}}$ & $* * *$ \\
\hline Income from FC (ETB) & 1420 & 3038 & 0 & 0 & NS \\
\hline Income from VC (ETB) & $4457^{\mathrm{a}}$ & $5371^{\mathrm{a}}$ & $6031^{\mathrm{a}}$ & $0^{\mathrm{b}}$ & $* * *$ \\
\hline Income from LS (ETB) & $94^{\mathrm{b}}$ & $11050^{\mathrm{b}}$ & $29573^{\mathrm{b}}$ & $206588^{\mathrm{a}}$ & $* * *$ \\
\hline
\end{tabular}

Means with different letters within rows are statistically different; ANOVA was used to compare continuous variables; $\mathrm{NS}=$ not significant $(\mathrm{P}>0.05) ; * *$ Denote significant difference at $\mathrm{P}<0.05$ and $* * *$ Denote significant differences at $\mathrm{P}<0.01$ respectively. $\mathrm{ETB}=$ Ethiopian Birr.

In Addis Ababa, farm area and number of fields per farm were small. Highest income per household was obtained from cLS. Vegetable crop (VC) and field crop (FC) gave relatively low income. Farms with relatively large area but no marketable produce (cluster 2, sFC) had also low income. In Jimma, farm area and number of fields per farm were larger than Addis Ababa and Adama. Interestingly, cLS farms in Jimma had a lower number of LS compared to cLS farms in Addis Ababa, but income from LS was higher at Jimma than Addis Ababa. cLS farms at Jimma had higher income than cLS farms at Addis Ababa and Adama because they owned relatively large size of land for LS farming and so had lower cost of animal feed input.

\subsubsection{Partial nutrient balances and nutrient use efficiencies}

Partial N, P and K balances differed significantly $(P<0.001)$ between the four farm types per each city (Tables 2.6). At Addis Ababa, Adama and Jimma the mean $\mathrm{N}$ balance was negative for FC farms (-30 kg ha ${ }^{-1}$ year $\left.^{-1}\right)$, but positive for VC (19 kg ha $\left.\mathrm{year}^{-1}\right)$ and LS (453 kg ha year $^{-1}$ ) farms. The mean $\mathrm{P}$ balance was positive in all farm types across the cities. The mean $\mathrm{K}$ balance was also positive for LS farms (264 kg ha-1 $\left.\mathrm{yr}^{-1}\right)$, but negative for FC (-17 kg ha $\mathrm{kear}^{-1}$ $\left.{ }^{1}\right)$ and $\mathrm{VC}\left(-70 \mathrm{~kg} \mathrm{ha}^{-1} \mathrm{yr}^{-1}\right)$ farms across the cities (Table 2.6). The variability of nutrient balances was high within a farm type (Figure 2.3-2.5). The nutrient use efficiency (NUE) also differed across the three cities. The mean $\mathrm{N}$ use efficiency ranged from 26 to $155 \%$ across the 
farm types of the three cities with the minimum in LS farms and the maximum in FC farms. Similarly the mean P use efficiency ranged from $26 \%$ to $55 \%$ with the minimum in LS farms and the maximum in $\mathrm{FC}$ farms. The mean $\mathrm{K}$ use efficiency ranged from 15 to more than $100 \%$ (Table 2.6).

Table 2.6 Mean partial balances $\left(\mathrm{kg} \mathrm{ha}^{-1}\right.$ year $\left.^{-1}\right)$ and use efficiencies $(\%)$ of nitrogen $(\mathrm{N})$, phosphorus $(\mathrm{P})$ and potassium $(\mathrm{K})$ at farm level for three main farm types in Addis Ababa, Adama and Jimma

\begin{tabular}{|c|c|c|c|c|c|c|c|c|c|c|c|c|c|}
\hline \multirow[b]{2}{*}{ Cities } & \multicolumn{2}{|l|}{ Flow } & \multicolumn{3}{|c|}{$\mathrm{N}$} & \multicolumn{4}{|c|}{$\mathrm{P}$} & \multicolumn{4}{|c|}{$\mathrm{K}$} \\
\hline & 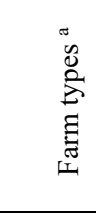 & $\begin{array}{l}\Xi \\
\Xi \\
\Xi\end{array}$ & $\begin{array}{l}\bar{\Xi} \\
\bar{z} \\
\overline{0} \\
0\end{array}$ & 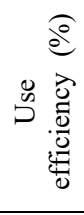 & 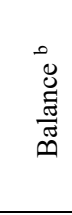 & $\begin{array}{l}\Xi \\
\Xi \\
\Xi\end{array}$ & $\begin{array}{l}\bar{E} \\
\bar{z} \\
\overline{0} \\
0\end{array}$ & 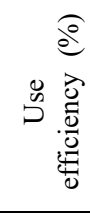 & $\begin{array}{l}0 \\
\ddot{U} \\
\text { ज्ञ } \\
\text { Фొ }\end{array}$ & $\begin{array}{l}\Xi \\
\Xi \\
\Xi\end{array}$ & $\begin{array}{l}\bar{E} \\
\bar{z} \\
\bar{E}\end{array}$ & 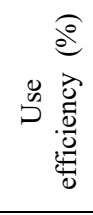 & 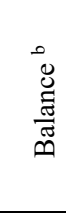 \\
\hline Addis & FC & 62 & 87 & 140 & $-25^{\mathrm{c}}$ & 30 & 13 & 43 & $17^{\mathrm{c}}$ & 1 & 16 & 1600 & $-15^{b}$ \\
\hline \multirow[t]{2}{*}{ Ababa } & $\mathrm{VC}$ & 106 & 87 & 82 & $19^{\mathrm{b}}$ & 38 & 10 & 26 & $28^{\mathrm{b}}$ & 11 & 80 & 727 & $-69^{c}$ \\
\hline & LS & 581 & 155 & 27 & $426^{\mathrm{a}}$ & 113 & 29 & 26 & $84^{\mathrm{a}}$ & 234 & 44 & 19 & $190^{\mathrm{a}}$ \\
\hline \multirow[t]{3}{*}{ Adama } & $\mathrm{FC}$ & 34 & 64 & 180 & $-30^{c}$ & 18 & 10 & 56 & $8^{c}$ & 1 & 13 & 1300 & $-12^{b}$ \\
\hline & $\mathrm{VC}$ & 93 & 79 & 85 & $14^{\mathrm{b}}$ & 30 & 9 & 30 & $21^{\mathrm{b}}$ & 1 & 78 & 7800 & $-77^{\mathrm{c}}$ \\
\hline & LS & 582 & 112 & 19 & $470^{\mathrm{a}}$ & 107 & 25 & 23 & $82^{\mathrm{a}}$ & 373 & 38 & 10 & $335^{\mathrm{a}}$ \\
\hline \multirow[t]{3}{*}{ Jimma } & FC & 78 & 113 & 145 & $-35^{\mathrm{c}}$ & 34 & 22 & 65 & $12^{\mathrm{c}}$ & 2 & 27 & 1350 & $-25^{b}$ \\
\hline & $\mathrm{VC}$ & 104 & 80 & 77 & $24^{\mathrm{b}}$ & 35 & 9 & 26 & $26^{\mathrm{b}}$ & 6 & 70 & 1167 & $-64^{c}$ \\
\hline & LS & 669 & 206 & 31 & $463^{\mathrm{a}}$ & 125 & 37 & 30 & $88^{\mathrm{a}}$ & 324 & 56 & 17 & $268^{\mathrm{a}}$ \\
\hline$P$ alue & & & & & $* * *$ & & & & $* * *$ & & & & $* * *$ \\
\hline
\end{tabular}

${ }^{\mathrm{a}} \mathrm{FC}=$ Field crop farms; $\mathrm{VC}=$ vegetable crop farms; $\mathrm{LS}=$ Livestock farms

${ }^{\mathrm{b}}$ Partial balance $=\sum$ Farmer managed IN flows $-\sum$ Farmer managed OUT flows. Field level flows were aggregated at farm level and then averaged per farm type

Means of nutrient balances with different letters within columns per city are statistically different;

ANOVA was used to compare means for partial nutrient balances of the farm types per city; *** Denote significant differences at $\mathrm{P}<0.01$ respectively 


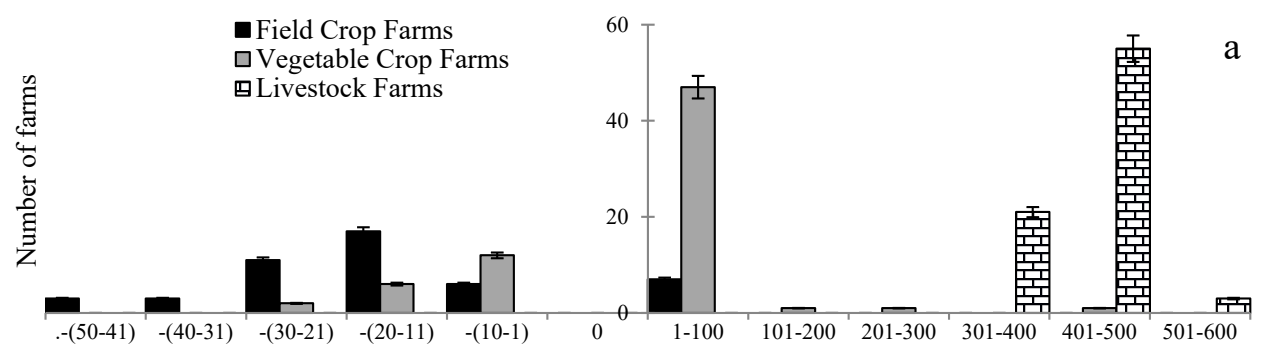

Partial nitrogen balance $\left(\mathrm{kg} \mathrm{ha}^{-1}\right.$ year $\left.^{-1}\right)$

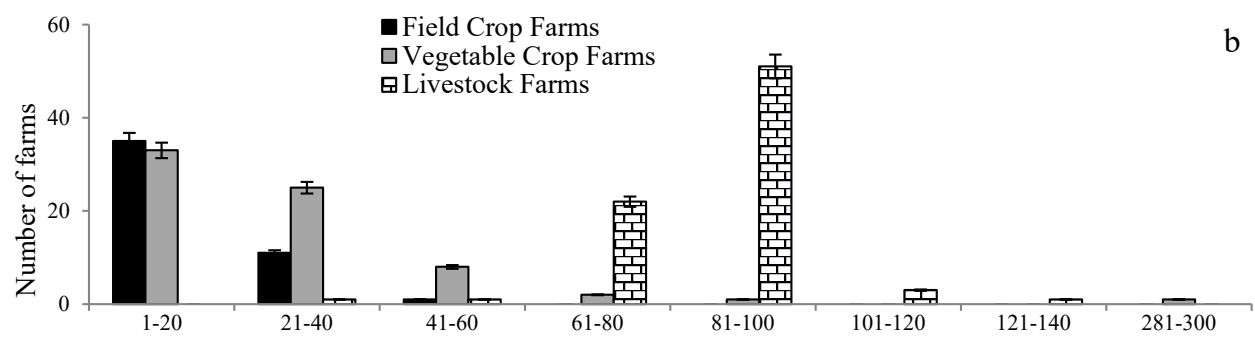

Partial phosphrous balance $\left(\mathrm{kg} \mathrm{ha}^{-1}\right.$ year $\left.^{-1}\right)$

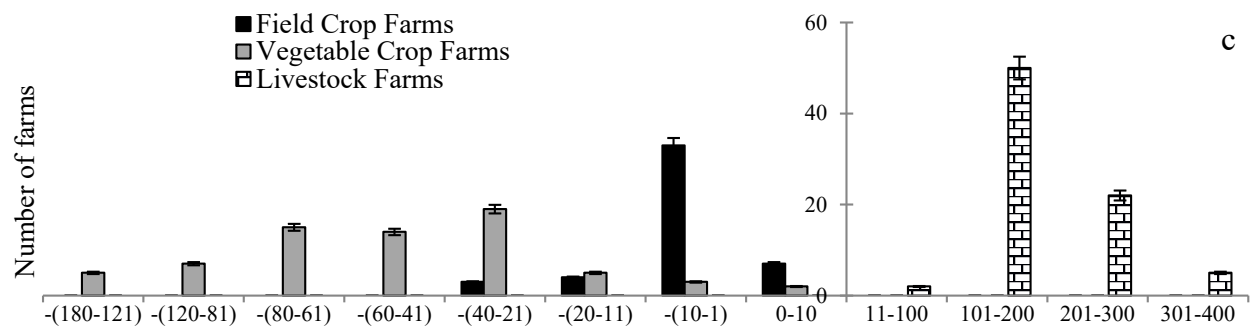

Partial potassium balance $\left(\mathrm{kg} \mathrm{ha}^{-1}\right.$ year $\left.^{-1}\right)$

Figure 2.3 Frequency distribution of partial (a) nitrogen, (b) phosphorus and (c) potassium balances for the different farm types at Addis Ababa city. 


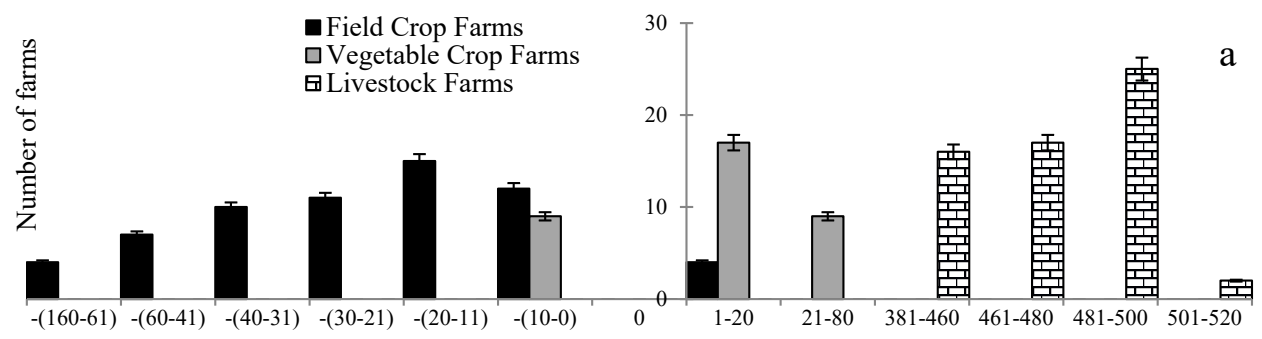

Partial nitrogen balance $\left(\mathrm{kg} \mathrm{ha}^{-1}\right.$ year $\left.{ }^{-1}\right)$

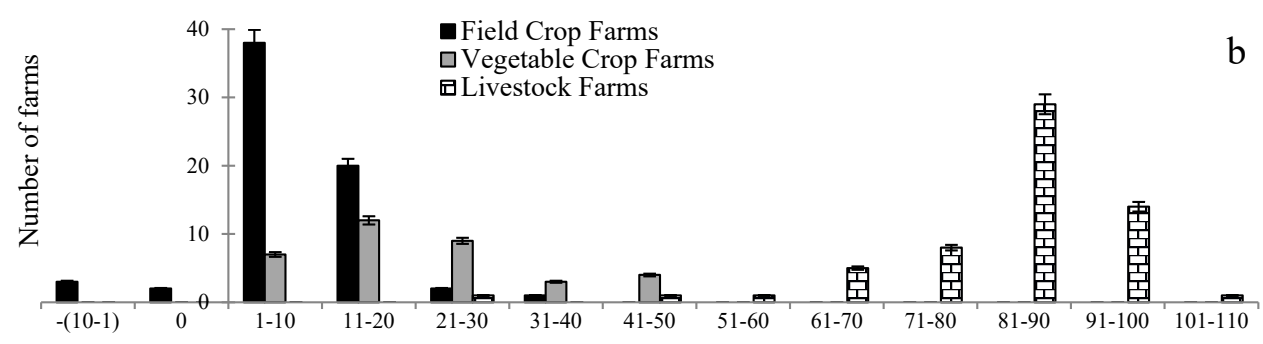

Partial phosphrous balance $\left(\mathrm{kg} \mathrm{ha}^{-1}\right.$ year-1 $\left.^{-1}\right)$

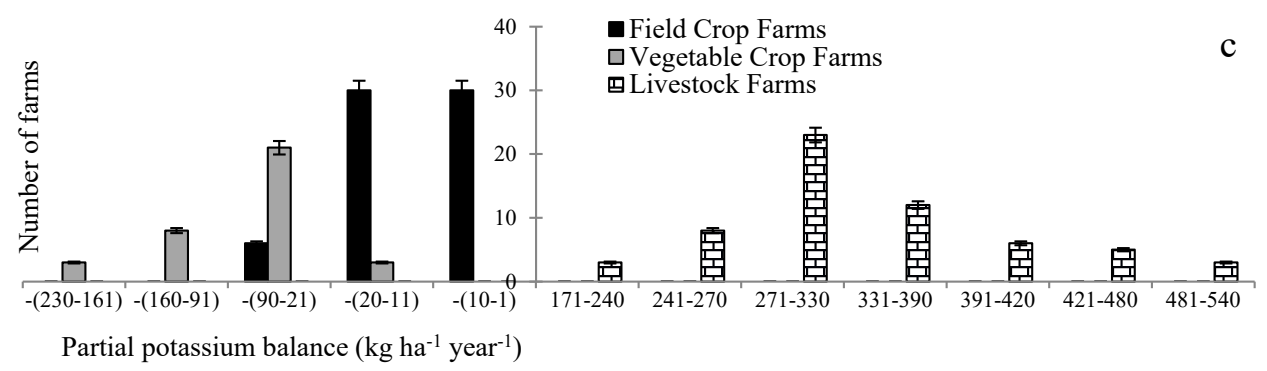

Figure 2.4 Frequency distribution of partial (a) nitrogen, (b) phosphorus and (c) potassium balances for the different farm types at Adama city. 


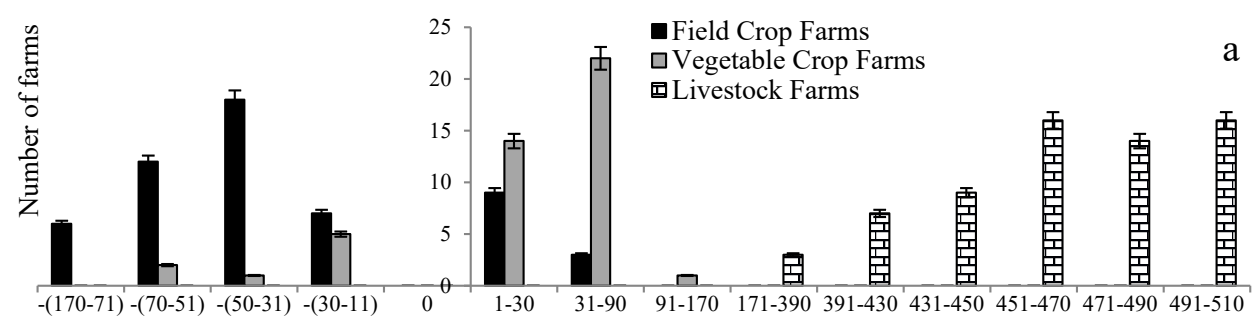

Partial nitrogen balance $\left(\mathrm{kg} \mathrm{ha}^{-1}\right.$ year $\left.{ }^{-1}\right)$

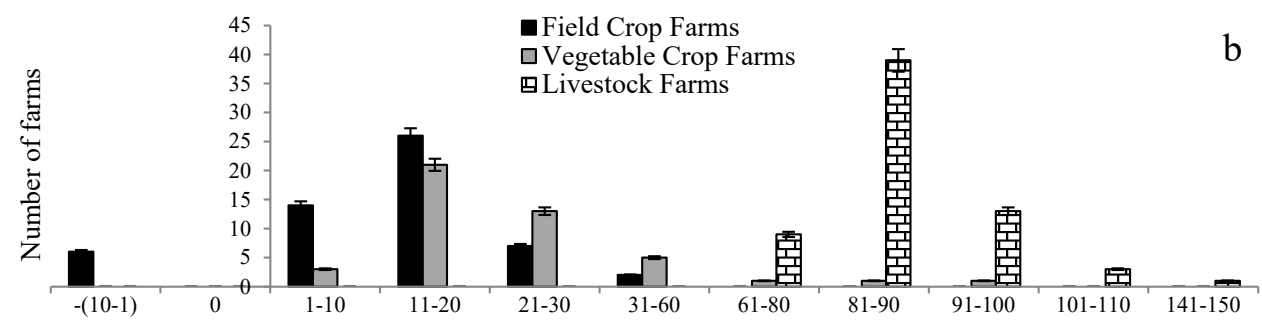

Partial phosphrous balance $\left(\mathrm{kg} \mathrm{ha}^{-1}\right.$ year $\left.^{-1}\right)$

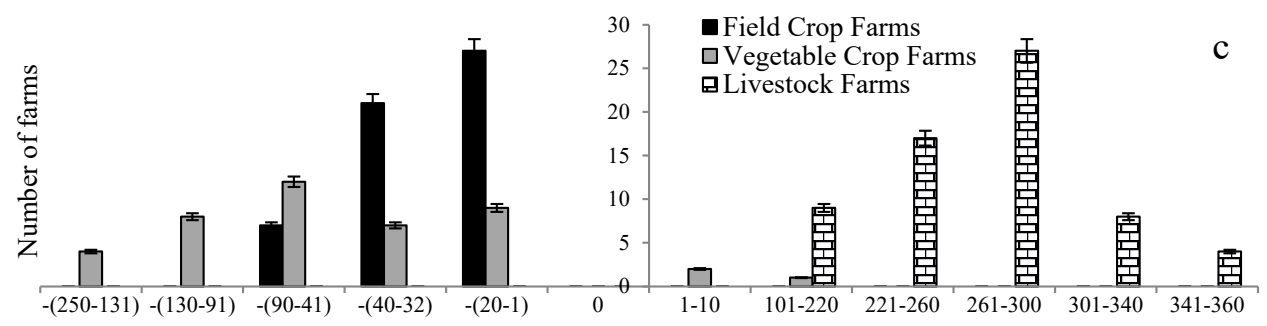

Partial potassium balance $\left(\mathrm{kg} \mathrm{ha}^{-1}\right.$ year $\left.^{-1}\right)$

Figure 2.5 Frequency distribution of partial (a) nitrogen, (b) phosphorus and (c) potassium balances for the different farm types at Jimma city. 


\subsubsection{Relationships between farm characteristics and nutrient balances}

The results of multiple regression analysis are summarized in Table 2.7. Socioeconomic variables explained $28 \%$ of the variances in $\mathrm{N}$ balance and only $10 \%$ of the variances in $\mathrm{P}$ balance for the main farm types of Addis Ababa. Similarly, 13\% of the variances in $\mathrm{N}$ balances and $10 \%$ of the variances in $\mathrm{P}$ balances were explained for Adama, and $33 \%$ of the variances in both $\mathrm{N}$ and $\mathrm{P}$ balances were explained for Jimma UPA.

Table 2.7 Summary of multiple regression analyses of the relationships between socioeconomic variables and partial $\mathrm{N}$ and $\mathrm{P}$ balances $\left(\mathrm{kg} \mathrm{ha}^{-1} \mathrm{year}^{-1}\right)$ of UPA systems in Addis Ababa $(\mathrm{N}=175)$, Adama $(\mathrm{N}=126)$ and Jimma $(\mathrm{N}=124)$

\begin{tabular}{lllllll}
\hline & \multicolumn{2}{l}{ Addis Ababa } & Adama & \multicolumn{3}{l}{ Jimma } \\
\cline { 2 - 7 } Variables & N balance & $\mathrm{P}$ balance & $\mathrm{N}$ balance & $\mathrm{P}$ balance & $\mathrm{N}$ balance & $\mathrm{P}$ balance \\
\cline { 2 - 7 } & $\beta$ & $\beta$ & $\mathrm{B}$ & $\beta$ & $\beta$ \\
\hline Family size & $.25^{* *}$ & $.2^{*}$ & .03 & .01 & -.05 & $-.04^{* *}$ \\
HH AGE & $.27^{* *}$ & .12 & .15 & .18 & $.38^{* *}$ & .32 \\
HH EDU & .14 & .11 & .01 & -.01 & $.17^{*}$ & .12 \\
UPA EXP & -.10 & .01 & $-.4^{* *}$ & $-.4^{* *}$ & $-.3^{* *}$ & $-.28^{* *}$ \\
HH INC & $.24^{* *}$ & $.2^{*}$ & -.13 & -.16 & $.33^{* *}$ & $.39^{* *}$ \\
$R^{2}$ & .28 & .10 & .13 & .10 & .33 & .33 \\
$F$ & $10.48^{* *}$ & $3.83^{* *}$ & $3.62^{* *}$ & $2.79^{* *}$ & $11.46^{* *}$ & $11.5^{* *}$ \\
\hline HH=household head; $\beta=$ Beta & & & & \\
$*=P<0.05$ and $* *=P<0.01$ & & & & &
\end{tabular}

\subsection{Discussion}

\subsubsection{Characterstics of urban and peri-urban farms}

Four UPA farm types were identified per city and six in total across the three cities (Table 2.3). The farm types identified include a wide diversity of the UPA activities, since they are based on multiple variables. Dossa et al. (2011), also reported that typology classification based on multiple variables performs better than classification based on a single criterion. Farms grouped in one typology are similar to each other in multiple variables than a sigle variable.

The UPA farm types were different notably in primary farming objectives, income, resource endowment, use of agricultural waste for soil fertility management and nutrient balances. The primary objective of farming was marketing for $75 \%$ of the UPA clusters per city (Table 2.4). Dossa et al. (2011) also found that the majority of the UPA farms in their study were market oriented. Yet, for $25 \%$ of the UPA farmers the primary objective of farming was home consumption and marketing was the second objective. These UPA farmers are resource-poor smallholder farmers with lack of capital and knowledge and therefore, produce FC with minimum inputs.

Livestock, vegetable and field crop production are common UPA activities in many developing countries (Abdulkadir et al., 2012; Pasquini et al., 2010). Among the six farm types identified, 
LS farms were economically the most important as they generate the highest income. Comparing LS with FC, Castel et al. (2010) reported also higher income for LS farms. The majority of LS farms in this study were land-less, and almost all feeds were scavenged and/or purchased from other regions. Condon et al. (2010) and Nigussie et al. (2015) also reported shortage of land as the main constraint for urban farmers. Land is very expensive in urban areas, and priority is given to residential areas and commercial centers demanded by the rapidly growing urban population at the rate of 3.8, 4.5 and 3.0\% per year in Addis Ababa, Adama and Jimma, respectively (Haile Mariam and Adugna, 2011). The remaining five farm types were mixed LS, VC and FC farming systems with relatively larger land holding (1.2 ha on average; Table 2.5). The mixed systems identified in our study disproved the traditional perception that LS, VC and FC productions are carried out by separate households (Veenhuizen and Danso, 2007). Instead, we found that most farmers were involved in mixed UPA activities with different levels of intensification. Graefe et al. (2008) and Dossa et al. (2011) also reported mixed UPA activities with diversified income sources.

\subsubsection{Agricultural waste and soil fertility management}

Use of agricultural wastes, crop residues and manure for soil fertility management was limited and different between the UPA clusters (Table 2.4). The inorganic fertilizers di-ammonium phosphate (DAP) and urea were the main external sources of plant nutrients because these are available on the market. This is in agreement with Baudron et al. (2014) and Nigussie et al. (2015). More than $50 \%$ of the UPA farmers didn't use agricultural waste for soil fertility management at least for the following reasons. First, close to the urban centers, where cLS farms were the dominant farming system, the farmers have no land. Therefore, they simply dumped animal manure in ditches and surroundings or left it unmanaged on the ground, while some dung was used as biofuel. Nigussie et al. (2015) also reported that a large quantity of waste was dumped in landfills in urban areas. Second, in subsistence field crop (sFC) and subsistence vegetable crop (sVC) farms, the options to use agricultural waste for soil fertility management were limited due to low levels of crop production and high biomass demand for feed and fuel. This maintains a vicious circle of low inputs of organic amendments and low outputs of crop residue. Competition between uses (feed, energy, soil fertility) for crop residues and manure has been reported also for other countries (Baudron et al., 2014; Jaleta et al., 2014; Valbuena et al., 2015). Most sFC farms had relatively large farm size (Table 2.5) but the crop fields are located far away from the homestead. This is one of the barriers for using external nutrient sources; the cost of transporting manure from landless cLS farms in urban areas to crop fields in peri-urban areas is high. The costs of inorganic fertilizers for use in crop fields is also relatively high. Consistent with this, Nigussie et al. (2015) reported FC farmers used over $75 \%$ manure for fuel and $80 \%$ crop residues for feed at Addis Ababa UPA. 


\subsubsection{Implications for intensification and improving NUE}

Partial N, P and K balances were significantly different between the farm types per city (Table 2.6). Abdulkadir et al. (2013) also reported positive NPK balances for LS farms in the UPA systems of Kano in Nigeria from their partial nutrient balance analysis fairly comparable to ours. Their method of input and output quantification was monitoring. Our estimations were based on surveys in short recall time of the farmers, immediately following the seasons of agricultural activities. The $\mathrm{cVC}$ farms had positive $\mathrm{N}$ and $\mathrm{P}$ balances but negative $\mathrm{K}$ balances. sFC farms had negative $\mathrm{N}$ and $\mathrm{K}$ balances but positive $\mathrm{P}$ balance. The positive $\mathrm{N}$ and $\mathrm{P}$ balances were related to the availability of NP fertilizers (DAP) on the market, which were affordable to $\mathrm{cVC}$ farmers but only marginally to $\mathrm{sFC}$ farmers. Potassium fertilizers were not available to farmers and hence negative $\mathrm{K}$ balances for the sFC and cVC farms. Nigussie et al. (2015) also found positive $\mathrm{N}$ and $\mathrm{P}$ balances in $\mathrm{cVC}$ farms but a negative $\mathrm{N}$ balance in $\mathrm{SFC}$ farms. Another reason for the negative $\mathrm{N}$ balance in $\mathrm{SFC}$ farms is the use of crop residues for feed and fuel. Valbuena et al. (2015) also reported strong competition on crop residues for feed, fuel and soil amendment even under low levels of cereal production systems in SSA and South Asian countries. Regression analysis showed strong association of farm income and nutrient balances across the cities, income was positively related to $\mathrm{N}$ and $\mathrm{P}$ balances. Age of the household head was positively but UPA experience of the head was negatively related to $\mathrm{N}$ and $\mathrm{P}$ balances; these correlations are not easy to explain. The relation between farm income and $\mathrm{N}$ and $\mathrm{P}$ balance was stronger for cLS farms than $\mathrm{cVC}$ and $\mathrm{sFC}$ farms across the three cities (Figure 2.6). The negative $\mathrm{N}$ balance in $\mathrm{sFC}$ farms were related to both the low income of these farms (Table 2.5) and to the relatively high price of fertilizers (Kassie et al., 2009). Abdulkadir et al. (2013) also found positive correlations between income and NP inputs in cLS farms. The high income of cLS farms was at the expense of nutrient accumulation in the urban environment (Table 2.6). In contrast, $\mathrm{sFC}$ and $\mathrm{sVC}$ farms generated low income and had negative nutrient balances, as crop residue and animal manure were used for feed and fuel, while inorganic fertilizers were little used.
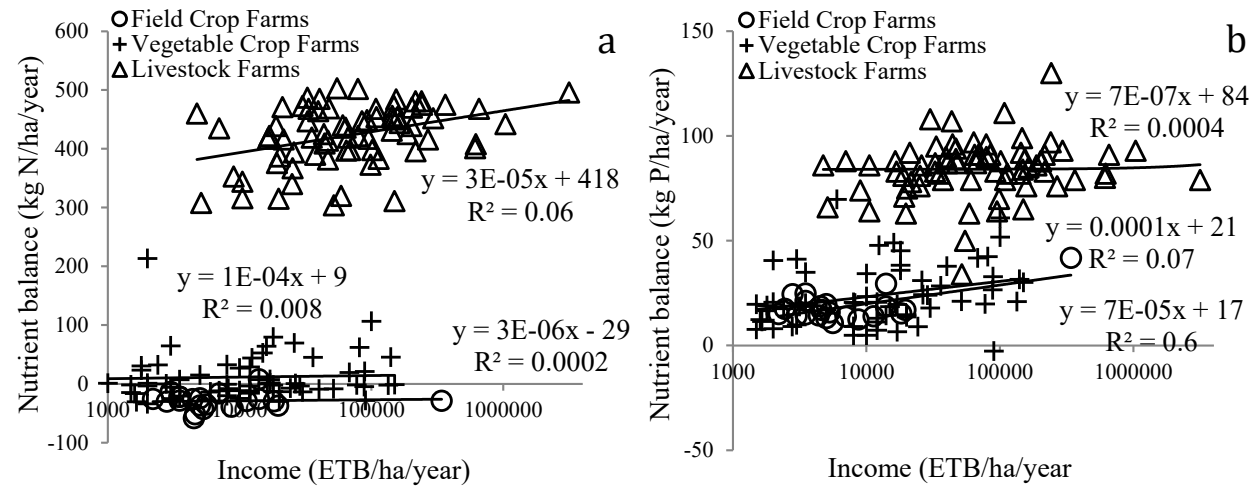

Figure 2.6 The relation between income and balances of (a) nitrogen and (b) phosphorus for field crop, vegetable crop and livestock farms at Addis Ababa city. Solid lines show linear regression. 
Abdulkadir et al. (2013), Diogo et al. (2010) and Wang et al. (2008) reported positive N balances for various UPA systems. The difference in the $\mathrm{N}$ balances of UPA systems between our study and these three other studies under relatively similar production systems could be due to the differences in farm types, the level of farm intensification, and livelihood assets and strategies. Therefore, farm-specific nutrient balance analyses are required, since farmers with similar production systems could have different soil fertility management strategies. The $\mathrm{K}$ balance was negative for both VC and FC farms since they have been using DAP and urea as the only inorganic fertilizers available on the market. In agreement with this, different researchers (Abdulkadir et al., 2013; Diogo et al., 2010; Wang et al., 2008) also found negative $\mathrm{K}$ balances in urban and peri-urban farming systems. These negative nutrient balances in our study indicate soil fertility depletion. Firdissa et al. (2007) also found declining soil fertility in FC systems. Van Beek et al. (2016) reported soil fertility decline in Ethiopian highlands. The results of our study suggest that the soil fertility decline in FC in UPA systems across the three cities is relatively similar to that of the small holder farmers in Ethiopian highlands. Following the differences in the nutrient balances, the nutrient use efficency (NUE) of the farms also differed greatly. The sFC had the highest NUE (N, P and K) and the cLS farms had the lowest (Table 2.6). The high NUE of the sFC farms indicate low nutrient input relative to nutrient output with the harvested crops. In contrast, the low NUE of the cLS farms indicate these farms had low nutrient output relative to nutrient input via animal feed, while the animal manure was not used for crop or feed production, due to shortage of land. Ideally, the animal maures of cLS farms were transported to FC and VC farms, where there is high demand of biomass. This would improve the nutrient balances of both LS farms (surpluses will decrease) and VC and FC farms (soil mining may be reversed). Thus, linking the specialized systems, FC and VC farms with high demand of organic ammendment and LS farms with surplus manure will increase the amount of manure utilized on farmlands and at the same time decrease the burden of the manure discharges into the environment. Njenga et al. (2010) and Nigussie et al. (2015) also recommend urban waste compost in FC and $\mathrm{VC}$ farms to enhance the agronomic and environmental sustainability of UPA. The linkage of FC and LS systems can improve the NUE of the systems. Lassaletta et al. (2014) suggested that integration of FC and LS farming systems can increase the NUE of the systems.

Farm characteristics and socioeconomic conditions hinder sustainable intensification of agricultural production (Baudron et al. 2014). We found that high cost of inputs for crop production and high cost of feed for livestock production were the major constraints of UPA across the three Ethiopian cities, in agreement with the findings of Kassie et al. (2009) and Dercon and Christiaensen (2011). Therefore, improving the access of FC and VC farmers to inorganic fertilizers, and of LS farmers to feeds must have a high priority. This may be achieved through better linkages between the different farming systems. Governmental policies aimed at sustainable intensification of UPA should focus on the exchange of manure and feeds between LS, VC and FC farms. Organic waste from urban households could also play a role. 


\subsection{Conclusions}

This study provides insights in the farm types, socioeconomic conditions and nutrient balances and constraints of UPA systems across three main cities in Ethiopia. Accordingly:

$>$ Six distinct UPA farm types with different resource endowments, level of household income and constraints were identified.

$>$ Among these, cLS production was the most important economic activity, followed by farm types integrating LS, VC and FC producton. sFC farming was mainly done by resource poor farmers for own consumption.

$>$ The land-less cLS farmers didn't use the manure for soil fertility management, because of lack of land. The manure was also not collected by other farmers; instead the manure nutrients accumulated in the farmstead and/or neglected and dissipated into the wider environment. These farms had positive $\mathrm{N}, \mathrm{P}$ and $\mathrm{K}$ balances.

$>\mathrm{sFC}$ farmers used crop residue mainly for fuel and not for soil fertility management. These farms had negative N, P and K balances.

$>$ High costs of feed for LS farms and high cost of inputs for FC and VC farms were the most important constraints for further development of UPA in the cities.

Therefore, improving access of farmers to agricultural inputs and putting in place a policy linking the farm systems can stimulate sustainable intensification of UPA. But still, the farm types greatly differed in nutrient management, nutrient balances and losses. Mechanistic and comprehensive analysis of nutrient flows and balances is required for better understanding and further improvement of the farm systems productive and environmental performances. 


\section{Chapter 2}

\section{References:}

Abdulkadir A., Dossa L.H., Lompo D.J.P., Abdu N., van Keulen H. (2012) Characterization of urban and peri-urban agro ecosystems in three West African cities. Int. J. Agric. Sustain. 4: 289-314.

Abdulkadir A., Leffelaar P.A., Agbenin J.O., Giller K.E. (2013) Nutrient flows and balances in urban and peri-urban agroecosystems of Kano, Nigeria. Nutrient Cycling in Agroecosystems 95:231-254.

Akhmat G., Bochun Y. (2010) Rapidly Changing Dynamics of Urbanization in China; Escalating Regional Inequalities and Urban Management Problems. J. Sustain. Dev 3: 153-158.

Alvarez S., Rufino M.C., Vayssières J., Salgado P., Tittonell P., Tillard E., Bocquier F. (2014) Whole-farm nitrogen cycling and intensification of crop-livestock systems in the highlands of Madagascar: An application of network analysis. Agricultural Systems 126: 25-37.

Baudron F., Jaleta M., Okitoi O., Tegegn A. (2014) Conservation agriculture in African mixed crop-livestock systems: expanding the niche. Agric. Ecosyst. Environ 187, 171-182.

Bekunda M., Manzi G. (2003) Use of the partial nutrient budget as an indicator of nutrient depletion in the highlands of southwestern Uganda. Nutr. Cycl. Agroecosyst 67: 187195.

Blum W.E.H. (1997) Soil degradation caused by industrialization and urbanization. Proceedings of the International Conference on Problems of Anthropogenic Soil Formation. Moscow, Russia pp. 3-5.

Castel J.M., Madry W., Gozdowski D., Roszkowska-Madra B., Dabrowski M., Lupa W., Mena Y. (2010) Family dairy farms in the Podlasie province, Poland: farm typology according to farming system. Span J Agric Res 8: 946-961.

Chatterjee S., Goswami R., Bandopadhyay P. (2015) Methodology of identification and characterization of farming systems in irrigated agriculture: Case Study in west Bengal state of India. J. Agric. Sci. Technol 17: 1127-1140.

Chen J. (2007) Rapid urbanization in China: A real challenge to soil protection and food security. Catena 69:1-15.

Condon P.M., Mullinix K., Fallick A., Harcourt M. (2010) Agriculture on the edge: strategies to abate urban encroachment onto agricultural lands by promoting viable human-scale agriculture as an integral element of urbanization. In: Pearson C.J., Pilgrim S., Pretty J., (Eds.), Urban agriculture: Diverse activities and benefits for city society. Int. J. Agric. Sustain vol. 8 (162), pp. 104-115.

David S., Gordon M., Cecilia T. (2010) Urbanization and its implications for food and farming. Phil. Trans. R. Soc. B 365: 2809-2820.

De Bon H., Parrot L., Moustier P. (2010) Sustainable urban agriculture in developing countries. A Review Agron. Sustain. Dev 30: 21-32. 
Dercon S., Christiaensen L. (2011) Consumption risk, technology adoption and poverty traps: evidence from Ethiopia. J. Dev. Econ 96, 159-173.

Diogo R.V.C., Buerkert A., Schlecht E. (2010) Horizontal nutrient fluxes and food safety in urban and peri-urban vegetable and millet cultivation of Niamey, Niger. Nutr Cycl Agroecosyst 87: 81-102.

Dossa L.H., Abdulkadir A., Amadou H., Sangare S., Schlecht E. (2011) Exploring the diversity of urban and peri-urban agricultural systems in Sudano-Sahelian West Africa: An attempt towards a regional typology. Landscape and Urban Planning 102: 197-206.

FAO (2011) The Place of Urban and Peri-urban Agriculture in National Food Security Programs. Rome, Italy

Firdisa T., Sjaastad E., Worku T. (2007) Livelihood dependence on urban agriculture in Addis Ababa, Ethiopia. M.Sc. Dissertation. Norwegian University of Life Sciences

Floater G., Rode P., Robert A., Kennedy C., Hoornweg D., Slavcheva R., Godfrey N. (2014) Cities and the New Climate Economy: the transformative role of global urban growth. New Climate Economy Cities Paper 01. LSE Cities. London School of Economics and Political Science

Graefe S., Schlecht E., Buerkert A. (2008) Opportunities and Challenges of Urban and PeriUrban Agriculture in Niamey, Niger. Outlook on Agriculture 37: 47-56.

Haile Mariam A., Adugna A. (2011) Migration and urbanization in Ethiopia: Addressing the spatial imbalance. In: Teller C. and Haile Mariam A. (eds.). The demographic transition and development in Africa: The unique case of Ethiopia. New York: Springer: 145165. doi:10.1007/978-90-481-8918-2-8

Haregewoin B. (2005) Urbanization and Urban Sprawl. Unpublished Master of science thesis No. 294, Department of Infrastructure Section of Building and Real Estate Economics, Kungliga Tekniska Högskolan, Stockholm

Israel G.D. (1992) Determining Sample Size. University of Florida, USA

Jackson H.L., Mtengeti E.J. (2005) Assessment of animal manure production, management and utilization in Southern Highlands of Tanzania. Livestock Research for Rural Development. Volume 17, Article \#110. http://www.lrrd.org/lrrd17/10/jack17110.htm Retrieved November 5, 2017

Jaleta M., Kassie M., Erenstein O. (2014) Determinants of maize stover utilization as feed, fuel and soil amendment in mixed crop-livestock systems, Ethiopia. Agric. Syst 134, 17-23.

Kassie M., Zikhali P., Manjur K., Edwards S. (2009) Adoption of organic farming techniques: evidence from semi-arid region of Ethiopia. Environment for Development: Discussion Paper Series 09-01, Resources for the Future, Washington DC, January 2009

Lassaletta L., Billen G., Grizzetti B., Anglade J., Garnier J. (2014) 50 years trends in nitrogen use efficiency of world cropping systems: the relationship between yield and nitrogen input to crop land. Environ. Res. Lett. 9: 105011. doi:10.1088/1748-9326/9/10/105011

Makita K., Fever E.M., Waiswa C., Bronsvoort M.D.C., Eisler M.C., Welburn S.C. (2010) Population-dynamics focused rapid rural mapping and characterization of the periurban interface of Kampala, Uganda. Land Use Policy 27: 888-897.

Nigussie A., Kuyper T., de Neergaard A. (2015) Agricultural waste utilization strategies and demand for urban waste compost: evidence from smallholder farmers in Ethiopia. Waste Manag 44:82-93. 
Njenga M., Romney D., Karanja N., Gathuru K., Kimani S., Carsan S., Frost W. (2010) Recycling nutrients from organic wastes in Kenya's Capital City. In: Prain G, LeeSmith D, Karanja N (Eds.) African Urban Harvest. Springer, New York, NY pp. 193212.

Nugent R. (2001) The impact of urban agriculture on household and local economies. Thematic Paper 3 in Bakker et al. (Eds.), Growing Cities, Growing Food: Urban Agriculture on the Policy Agenda, Fefdafing. DSE, Fefdafing

Pacini G.C., Colucci D., Baudron F., Righi Corbeels E.M., Tittonell P., Stefanini F.M. (2014) Combining Multi-Dimensional Scaling And Cluster Analysis To Describe The Diversity of Rural Households. Expl Agric 50: 376-397.

Pasquini M.W., Weinberger K., Assogba-Komlan F., Kouame C., Akpologan F., Djidji H. (2010) Characterizing urban and peri-urban production systems for African indigenous vegetables in four cities in Benin and Cote d'Ivoire. In: Paper Presented at International Symposium on Urban and Peri-urban Horticulture in the Century of Cities, 5-9 December, 2010, Dakar, Senegal

Pearson L.J., Pearson L., Pearson C.J. (2010) Sustainable urban agriculture: stock take and opportunities. Int. J. Agric. Sustain 8: 7-19.

UN (2015) World Population Prospects: The 2015 Revision, Key Findings and Advance Tables. Working Paper No. ESA/P/WP.241

Valbuena D., Tui S.H., Erenstein O., Teufel N., Duncan A., Abdoulaye T., Swain B., Mekonen K., Germaine I., Gerard B. (2015) Identifying determinants, pressures and tradeoffs of crop residue use in mixed smallholder farms in Sub-Saharan Africa and South Asia. Agric. Syst 134, 107-118.

van Beek C.L., Elias E., Yihenew G.S., Heesmans H., Tsegaye A., Feyisa H., Tolla M., Mamuye M., Gebremeskel Y., Mengist S. (2016) Soil nutrient balances under diverse agro-ecological settings in Ethiopia. Nutr Cycl Agroecosyst 106:257-274.

van Veenhuizen R., Danso G. (2007) Profitability and sustainability of urban and peri-urban agriculture. Agricultural Management, Marketing and Finance Occasional Paper 19, FAO Rome, Italy

Wang F., Wang Z., Kou C., Ma Z., Zhao D. (2016) Responses of Wheat Yield, Macro- and Micro-Nutrients, and Heavy Metals in Soil and Wheat following the Application of Manure Compost on the North China Plain. PLoS ONE, 11(1), e0146453. http://doi.org/10.1371/journal.pone.0146453

Wang H.J., Huang B., Shi X.Z., Darilek J.L., Yu D.S., Sun W.X., Zhao Y.C., Chang Q., Öborn I. (2008) Major nutrient balances in small-scale vegetable farming systems in periurban areas in China. Nutr Cycl Agroecosyst 81: 203-218.

Zezza A., Tasciotti L. (2010) urban agriculture, poverty and food security: Empirical evidence from a sample of developing countries. Food Policy 35: 265-273. 



\section{CHAPTER 3}

\section{Nitrogen allocation and recycling in peri-urban mixed crop-livestock farms in Ethiopia}

This chapter is published as:

Tadesse ST, Oenema O, Van Beek C, Ocho FL (2019) Nitrogen allocation and recycling in peri-urban mixed crop-livestock farms in Ethiopia. Nutr Cycl Agroecosyst 115: 281-294. doi.org/10.1007/s10705018-9957-z. 


\begin{abstract}
Mixed crop-livestock (MC-LS) farms are assumed to be more environmental-friendly than specialized livestock systems, due to their better options for internal nutrient recycling. However, there are large differences among MC-LS farms in nutrient allocation and recycling. Here, we posit that the relative allocation of nitrogen to crop and livestock compartments, expressed as crop-livestock ratio (CLS), determines the performance of MC-LS farms. Among 300 urban and peri-urban farms studied in 2014, 42 MC-LS farms (Addis Ababa: 20; Jimma: 22) were re-interviewed in 2016, using MonQIt (monitoring tool) questionnaire. The performances of these farms were evaluated using partial nitrogen balance (PNB), $\mathrm{N}$ use efficiency (NUE), N recycling index (NRI) and net farm income (NFI). CLS was negatively related to N input, PNB and NFI. Livestock-oriented MC-LS farms had 4-5 times higher N input and 7 times higher PNB than crop-oriented MC-LS farms, because they had 2-4 times higher NFI and purchased more external $\mathrm{N}$ input. This indicated that $\mathrm{N}$ allocation has significant environmental and economic implications. Sensitivity analyses suggested that NUE at farm system level can be improved by $20-25 \%$ and $\mathrm{N}$ recycling (NR) by $10-20 \%$ over the current condition. In conclusion, MC-LS farms are diverse, and much of the diversity can be captured by the CLS indicator. NUE and NR of peri-urban MC-LS farms in Ethiopia can be significantly improved through NUE enhancing measures: targeted exchange of crop residues and manure between crop and livestock activities within and between farms and improving animal NUE through breeding and precision feeding.
\end{abstract}

Key words: Crop-livestock ratio (CLS); smallholder; NUE; food security; circular economy 


\subsection{Introduction}

Urban and peri urban agriculture (UPA) provides significant contributions to the food security of most low income countries (Satterthwaite et al., 2010). Currently, millions of urban residents depend on UPA for food consumption and income. For instance, in urban and peri-urban areas of East Africa, 17-36\% of the population grow crops (C) and/or keep livestock (LS) (Satterthwaite et al., 2010). Large share of UPA farms are mixed crop-livestock (MC-LS) systems, i.e., produce both crops and animals in variable proportions. These MC-LS systems produce half of the current world's food (Duncan et al., 2013). For instance, these systems produce $50 \%$ of world cereals, $34 \%$ of global beef and $30 \%$ of global milk. MC-LS systems also produce $65 \%$ beef, $75 \%$ milk and $55 \%$ lamb in the developing world (Tarawali et al., 2011) and support the livelihood of more than $80 \%$ of the population living in the developing part of the world (Blummel, 2013). These MC-LS systems are also the backbone of African agriculture, ensuring hundreds of millions of people are food secure (Tarawali et al., 2011).

Globalization, urbanization and income growth are fueling substantial increases in the demand for animal derived food, especially in rapidly developing countries (Thornton, 2010). In response to the increasing food demand of the urban population, MC-LS peri-urban farms are recognized as multifunctional systems that provide a significant fraction of the necessary food, through both crop and livestock production activities (Zasada, 2011). Due to the multifunctionality of these systems, the crop (C) and livestock (LS) compartments within MC-LS farms can be either complementary or competitive. Complementarity occurs when one farm compartment provides inputs to the other. A trade off (or competition) occurs when a resource is allocated to one compartment at the expense of another; for example, the available cash money may be used to buy fertilizer instead of animal feed, and crop residues may be used for animal feed instead of soil fertility amendment (Valbuena et al., 2015). The trade-off will be small in the second case if the resulting animal manures are returned to the cropland. Complementarity between farm compartments is efficiently employed when the cropland provides the feed for the animals and all manures are returned to the cropland. In such mixed systems nutrients are efficiently recycled between crop and livestock compartments, which may strengthen environmental sustainability (Gupta et al., 2012). When household wastes are also returned to livestock and/or crop land, smallholder mixed farming systems can be considered a circular economy (Cassidy et al., 2013). Consequently, MC-LS systems are assumed to be more environment friendly and sustainable than specialized crop production and animal production systems (Marton et al., 2016; Sneessens et al., 2016). In UPA, specialized crop production systems often rely on the import of fertilizer nutrients, while specialized animal production rely on the import of animal feed and have great difficulties with appropriate manure disposal, for example, Strokal et al. (2016) and Liu et al. (2017b). However, MC-LS systems are under pressure of the market regime, as specialized crop production and animal production systems often produce at lower costs than mixed systems. This could be due to the higher resource constraints leading to competition between crop and livestock compartments in MC-LS systems and relatively the small size of MC-LS systems and the related economy of scale. Large specialized and intensive systems can often comply also much easier with the 
requirements of the food processing industries and suppliers, and thereby get more easy access to new information and technologies. A practical challenge facing MC-LS farms is therefore to achieve a sustainable increase in crop and livestock production within emerging resource constraints, especially in peri-urban areas (Cassidy et al., 2013; Goulding et al., 2008), and thereby to remain economically competitive. Thus, in resource constrained peri-urban areas, intensification of production may lead to competition between soil/crop and livestock compartments in MC-LS farms for land, crop residues and investments (Valbuena et al., 2015). The choice of investment and $\mathrm{N}$ allocation either to crop or livestock compartments may have implications for the environmental and economic performances of MC-LS farms (Tittonell et al., 2007). Thus, $\mathrm{N}$ allocation to either the soil/crop or the livestock compartments may differ considerably, also because MC-LS farms are heterogeneous with respect to the use of inputs (Ryschawy et al., 2012). Thus, understanding $\mathrm{N}$ allocation effects on the economic and environmental performances of MC-LS systems is vital to suggest $\mathrm{N}$ management options for enhancing NUE and N recycling (NR) in peri-urban MC-LS farms. Yet, there is no practical method to characterize nutrient allocation to soil/crop and livestock compartments in MC-LS farm systems, and there are no systematic analyses. This may hamper a proper assessment of environmental and economic performances of the MC-LS farms. Here, we report on a method for examining the impacts of $\mathrm{N}$ allocation in mixed farming systems. A set of five indicators was used to evaluate the environmental and economic performances of peri-urban MC-LS farms in Ethiopia.

\subsection{Materials and methods}

\subsubsection{Concept; $\mathbf{N}$ allocation and indicators}

Mixed crop-livestock (MC-LS) farms are composed of three compartments, i.e., soil/crop, livestock and household. The soil/crop and livestock compartments directly or indirectly provide food and income to the farm household, and the relative importance has impact on the nutrient flows (Rufino et al., 2009a). MC-LS farms may differ in the relative allocation of external nutrient inputs to the soil/crop and livestock compartments. Accordingly, nutrient allocation indicates the relative quantity of nutrient flows either to the crop or livestock compartment depending on the relative importance of the crop or livestock compartment within a farm. In crop-oriented MC-LS farms more investment is on external $\mathrm{N}$ input to the crop compartment than the livestock to get higher crop yield and residue to feed their livestock. In livestock-oriented MC-LS farms more investment is on external $\mathrm{N}$ input to the livestock compartment than the crop to get higher milk yield and manure to fertilize their crop lands (Figure 3.1). These differences in nutrient allocation in MC-LS farms may relate to economic opportunities, cultural preferences and availability of capital to purchase crop and livestock inputs (Kindu et al., 2014). MC-LS farms may allocate external nutrient inputs to the soil/crop or the livestock compartments, or both. The crop-livestock ratio (CLS) indicates the proportion of external nutrient inputs allocated to the crop compartment. Here, we express CLS in terms of $\mathrm{N}$, because $\mathrm{N}$ is often the most limiting nutrient and a key factor in the intensification of agricultural production systems (Rufino et al., 2006). 

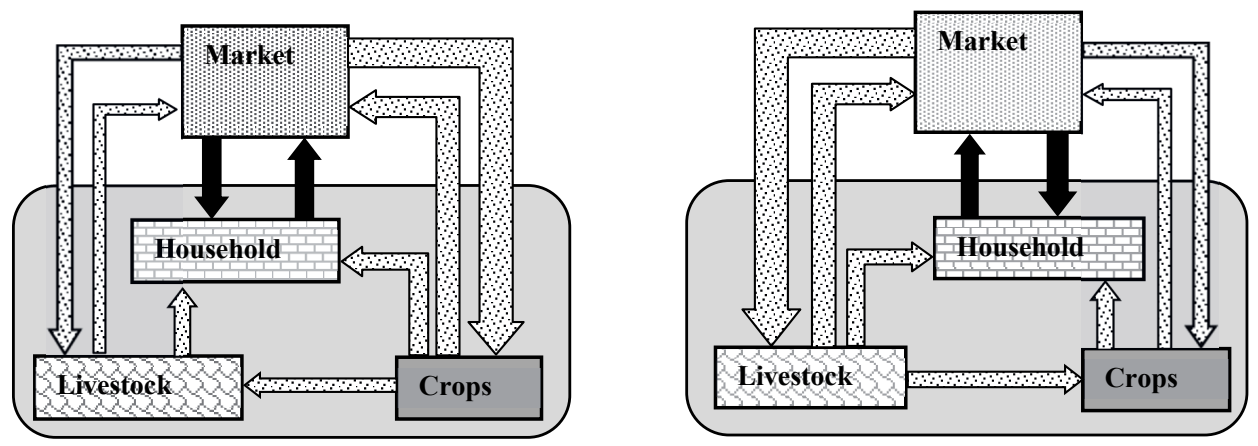

Figure 3.1 Nutrient allocation in a MC-LS farm and direction of net flows between crop and livestock compartments of a farm and the market. The solid black arrows indicate the cash flows. The spotted white arrows indicate the direction of nutrient flows and their size indicates the quantity of nutrient flows depending on the relative importance of crop or livestock compartment within a farm. Accordingly, on the left: soil/crop oriented nutrient allocation (CLS > 0.5); the big arrow from market to crops indicates more nutrients flow to the soil/crop compartment than to the livestock. Right: livestock oriented nutrient allocation (CLS $<0.5)$; the big arrow from market to livestock indicate more nutrients flow to the livestock compartment than to the soil/crop compartment.

To evaluate the impacts of $\mathrm{N}$ allocation in MC-LS farms, we used $\mathrm{N}$ input, $\mathrm{N}$ output, partial $\mathrm{N}$ balance (PNB), $\mathrm{N}$ use efficiency (NUE) and $\mathrm{N}$ recycling index (NRI) as $\mathrm{N}$ flow indicators and gross margins (GM) and net farm income (NFI) as farm profitability indicators. The indicators were calculated as follows.

CLS is the ratio between $\mathrm{N}$ input (IN) to the soil/crop compartment and the sum of $\mathrm{N}$ inputs to both soil/crop and livestock compartments (Eq. 3.1) as explained in van Beek et al. (2009).

$$
C L S=\frac{I N_{\text {crop }}}{I N_{\text {crop }}+I N_{\text {livestock }}}
$$

$\mathrm{N}$ input $(\mathrm{IN})$ is the sum of inorganic $(\mathrm{I} 1 \mathrm{~N})$ and organic $(\mathrm{I} 2 \mathrm{~N}) \mathrm{N}$ inputs (Eq. 3.2). Inorganic and organic N inputs are imported for crop and livestock activities of MC-LS farms and obtained from the MonQIt (Monitoring for Quality Improvement tool) questionnaire (Section 3.2.3).

$$
I N=I 1_{N}+I 2_{N}
$$

$\mathrm{N}$ output $(\mathrm{ON})$ is the sum of $\mathrm{N}$ outputs in harvested crop, livestock and milk $\left(\mathrm{O} 1_{\mathrm{N}}\right)$ and crop residue and manure $(\mathrm{O} 2 \mathrm{~N})($ Eq. 3.3).

$$
O N=O 1_{N}+O 2_{N}
$$

Partial $\mathrm{N}$ balance (PNB) is the difference in farmer managed $\mathrm{N}$ inputs and $\mathrm{N}$ outputs (Eq. 3.4).

$$
P N B=I N-O N
$$


$\mathrm{N}$ use efficiency (NUE) is the ratio between the harvested $\mathrm{N}$ output and managed $\mathrm{N}$ inputs (Eq. $3.5)$ according to Wang et al. (2008).

$$
N U E=\frac{O N}{I N} * 100
$$

Total $\mathrm{N}(\mathrm{TN})$ use of the farm is the sum of $\mathrm{N}$ recycled (NR) in the farm and $\mathrm{N}$ input imported from external sources (IN) (Eq. 3.6) as indicated in Rufino et al. (2009a).

$$
T N=N R+I N
$$

$\mathrm{N}$ recycling index (NRI) is the proportion of TN that is recycled (NR) (Eq. 3.7) as expressed by Rufino et al. (2009a) and Banerjee et al. (2017).

$$
N R I=\frac{N R}{T N(N R+I N)}
$$

Gross Margin (GM) is calculated at the farm level (Eq. 3.8).

$$
G M=G V-V C
$$

Where, GV (gross value) is the value of the total output and VC (variable costs) is the costs of all inputs, over some accounting period (e.g., a year).

The net farm income (NFI) is derived from GM and the total fixed costs of the farm (Eq. 3.9).

$$
\mathrm{NFI}=\mathrm{GM}-\mathrm{FIXCOST}
$$

Where, FIXCOST is the total fixed costs of the farm (e.g., costs of dairy barn and etc.).

\subsubsection{Study sites}

Two contrasting cities in Ethiopia (Addis Ababa and Jimma) were selected as study area. The cities have a total population of 3.1 and 0.2 million and a population growth rate of 3.8 and $3 \%$ per year, respectively (Haile Mariam and Adugna, 2011). Addis Ababa is the political and economic capital of the country. Jimma is the commercial hub of the Southwestern part of the country and known as the origin of Coffee (Coffea arabica L.). The cities differ in their biophysical characteristics and agro-ecology (Table 3.1). Addis Ababa has ten sub-cities and the majority of UPA farms are found in five sub-cities (Akaki-Kaliti, Bole, Kirkos, Kolfe-Keranio and Nifasilk-Lafto), and these were selected for this study. In Jimma all the eight districts within the city were selected. The UPA in Addis Ababa and Jimma are variable mixtures of dairy farms, vegetables farms, subsistence field crops farms and mixed crop-livestock (MCLS) farms (Tadesse et al., 2018). 
Table 3.1 Agro-ecology and bio-physical features of Addis Ababa and Jimma urban and periurban areas

\begin{tabular}{lll}
\hline Cities & Addis Ababa & Jimma \\
\hline Location & $9^{\circ} 1^{\prime} \mathrm{N}$ and $38^{\circ} 44^{\prime} \mathrm{E}$ & $7^{\circ} 40^{\prime} \mathrm{N}$ and $36^{\circ} 50^{\prime} \mathrm{E}$ \\
Rainfall (mm/year) & 1165 & 1510 \\
Altitude $(\mathrm{m})$ & $2,300-3,000$ & 1780 \\
Mean low and high temperature $\left({ }^{\circ} \mathrm{C}\right)$ & 11 and 23 & 12 and 27 \\
Major soil types & Chromic and Pellic & Chromic Nitisol and \\
& Vertisol & Cambisol \\
Agro-ecological zoning & Moderately warm to & Sub humid, moderately \\
& cool moist mid & warm to cool mid \\
highlands & highlands \\
Main crops & Barley, beans, wheat, & Coffee, tea, spices, wheat, \\
& teff, potato, highland & teff, barley, maize, \\
& oilseeds, highland & sorghum, beans \\
& pulses & \\
Main livestock categories & Cattle mainly exotic & Cattle mainly exotic dairy \\
& dairy cows, local breed & cows, local breed cows \\
& cows and oxen, sheep & and oxen, sheep and goat \\
& and goat & \\
Herd size (TLU/farm) & 9 & 6 \\
Mean farm size (ha) & 1.5 & 1.4 \\
\hline
\end{tabular}

\subsubsection{Data collection}

Among 300 UPA farms interviewed in 2014, 42 farms (Addis Ababa: 20, Jimma: 22) were categorized as MC-LS farm types (Tadesse et al., 2018). These farms were selected and reinterviewed in 2016 using the standardized questionnaire of MonQIt (Monitoring for Quality Improvement tool) (van Beek et al., 2010). Farm management data on household composition, fields and farm characteristics and nutrient management data including use of inputs for the different crops and livestock activities, flows between activities, crop yields, animal production, sales, input and output prices were collected using the MonQIt model questionnaire. MonQIt is a tool for monitoring the management and performance of smallholder farming systems to understand and pave the ways for improvement in social, economic, agricultural and environmental conditions of farming systems (www.monqi.org; Vlaming et al. 2012). Data was entered into the MonQIt model, which combines the farm data with the background data on e.g., nutrient contents of products, conversion factors from farmer used units (e.g., head loads) to SI units, etc. Data on nutrient (e.g. N, P and K) contents of crops, crop residues, milk and manure were obtained from literature (Alvarez et al., 2014; Wang et al., 2016) and included in the background database of the model. Combination of farm surveys, field observations and modelling provided the basis for computing CLS, N flows and farm income indicators (Section 3.2.1). 


\subsubsection{Data analysis}

An independent-samples $t$-test was conducted to test for significant differences in $\mathrm{N}$ flows and income between MC-LS farms with crop-oriented N allocation and MC-LS farms with livestock-oriented $\mathrm{N}$ allocation using an alpha level of 0.05 . Linear regression of $\mathrm{N}$ allocation (CLS) versus $\mathrm{N}$ flows and NFI was done. Correlation analysis was done among $\mathrm{N}$ flows and farm income indicators. For all analysis, SPSS statistical software version 23 was used.

In addition, a range of sensitivity analyses were made to explore the possible range of values for NUE of MC-LS farms, as function of CLS, NRI and various additional measures for enhancing NUE and N recycling (NR) in MC-LS farms. NUE of livestock production systems depends on the NUE at animal level, the $\mathrm{N}$ losses from animal manure, the amounts and recoveries of applied manure $\mathrm{N}$ and fertilizers $\mathrm{N}$ in the harvested feed and the relative proportion of purchased feed versus farm grown feed (Liu et al., 2017b). In MC-LS systems, NUE at system level depends on the NUE at animal level, amounts of sold crops and the amounts and recoveries of applied manure $\mathrm{N}$ and fertilizers $\mathrm{N}$ to the harvested crops. We extended the simple model of Liu et al. (2017b) to analyze the effects of changes in the NUE at animal level, CLS, manure $\mathrm{N}$ recycling, emissions (e.g. $\mathrm{CH}_{4}, \mathrm{~N}_{2} \mathrm{O}$ and $\mathrm{NH}_{3}$ ) and their mitigation measures (appropriate manure handling, storage and application to reduce manure $\mathrm{N}$ losses), and of manure and fertilizer $\mathrm{N}$ recovery enhancing measures on the NUE of MC-LS farms. NUE values ranging from 5 to $35 \%$ at animal level were combined with five $\mathrm{N}$ management options (Table 3.2), and with different CLS values.

Table 3.2 Assumptions of $\mathrm{N}$ management options for the sensitivity analyses to explore the possible range of NUE at farm level of MC-LS farms in peri-urban areas of Addis Ababa and Jimma

\begin{tabular}{lccc}
\hline \multirow{2}{*}{$\begin{array}{l}\text { Options } \\
\text { (OPT) }\end{array}$} & Manure N loss & Manure N recovery & Fertilizer N recovery \\
\cline { 2 - 4 } 1 & & 30 & $\%$ \\
2 & 70 & 60 & 40 \\
3 & 30 & 30 & 40 \\
4 & 70 & 60 & 70 \\
5 & 70 & 60 & 70 \\
\hline
\end{tabular}




\subsection{Results}

\subsubsection{General characteristics of the farms}

The peri-urban MC-LS farms of the two cities differed in farm land size and number of plots, management, market orientation and income (Table 3.3). Jimma farms were smaller but had more plots compared to Addis Ababa farms. Female headed farms are more in Addis Ababa $(1: 6)$ than in Jimma (1:10). Farms in Addis Ababa were more market oriented $(66 \%$ market share) and had higher gross margin (GM) in both crop and livestock compartments than the farms in Jimma. Mean CLS ratios were rather similar in the two study sites, but the variation between farms was large. A total of 12 farms in both Addis Ababa and Jimma had allocated more $\mathrm{N}$ to the crop compartment and are hereafter categorized as MC-LS farms with croporiented $\mathrm{N}$ allocation (CLS > 0.5). The remaining 8 farms in Addis Ababa and 10 farms in Jimma had allocated more $\mathrm{N}$ to the livestock compartment and are categorized as MC-LS farms with livestock-oriented $\mathrm{N}$ allocation (CLS $<0.5$ ) (Table 3.4 and Figure 3.2).

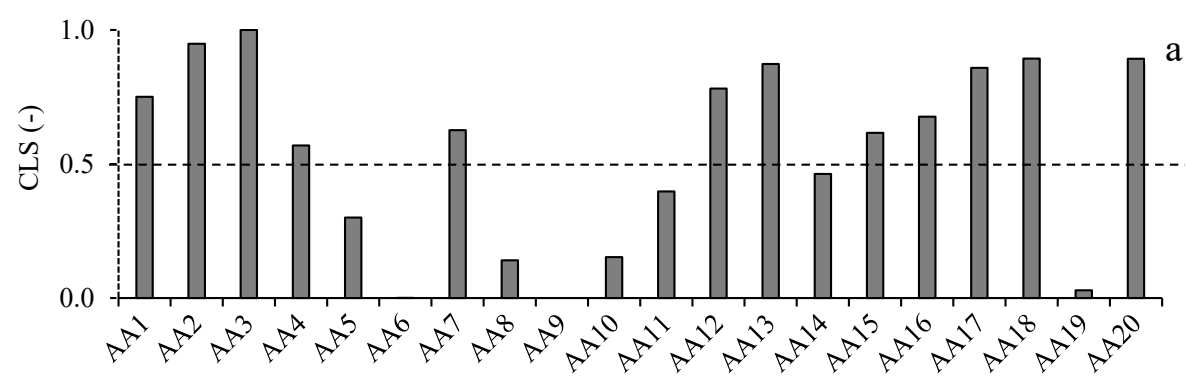

Mixed crop-livestock (MC-LS) farms at Addis Ababa (AA1-20)

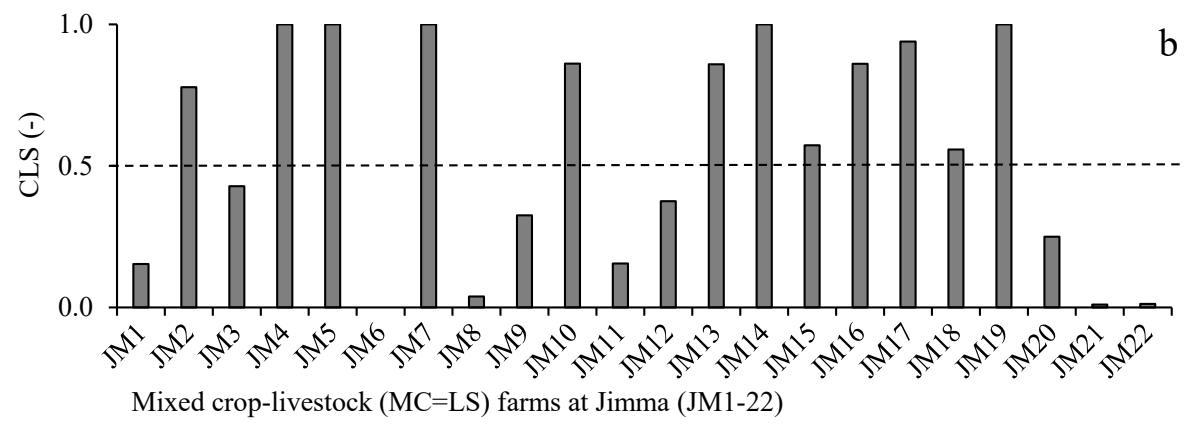

Figure 3.2 Crop-livestock ratio (CLS) of mixed crop-livestock (MC-LS) farms: (a) indicating 12 farms with crop-oriented $\mathrm{N}$ allocation (CLS > 0.5) above the broken line at CLS of 0.5 and 8 farms with livestock-oriented $\mathrm{N}$ allocation $(\mathrm{CLS}<0.5)$ below the broken line at CLS of 0.5 at Addis Ababa and (b) similarly showing 12 crop-oriented and 10 livestock-oriented MC-LS farms at Jimma. 
Table 3.3 Characteristics (means \pm standard deviations) of MC-LS farms in Addis Ababa and Jimma

\begin{tabular}{|c|c|c|}
\hline Characteristics & Addis Ababa $(\mathrm{n}=20)$ & Jimma $(n=22)$ \\
\hline Average number of household members & $7 \pm 3$ & $6 \pm 2$ \\
\hline Average age of household head (HH) (years) & $43 \pm 15$ & $47 \pm 10$ \\
\hline Ratio of female to male headed household (F:M) & $1: 6$ & $1: 10$ \\
\hline Education level of HH (years) & $6 \pm 5$ & $6 \pm 4$ \\
\hline Farm size (ha) & $1.5 \pm 1$ & $1.4 \pm 1$ \\
\hline Partial $\mathrm{N}$ balance $\left(\mathrm{kg} \mathrm{N} \mathrm{ha}^{-1}\right.$ year $\left.^{-1}\right)$ & $138 \pm 219^{b}$ & $89 \pm 198$ \\
\hline Net farm income (NFI) (1000 ETB/ha/year) ${ }^{c}$ & $149 \pm 248$ & $119 \pm 211$ \\
\hline Average plot size (ha) & $0.3 \pm 0.16$ & $0.2 \pm 0.12$ \\
\hline Number of different crops per farm & $5 \pm 2$ & $6 \pm 3$ \\
\hline Average number of plots & $5 \pm 2$ & $7 \pm 4$ \\
\hline Livestock number in TLU & $9 \pm 9$ & $6 \pm 4$ \\
\hline Gross margin crops (1000 ETB/ha/year) ${ }^{a}$ & $57 \pm 72$ & $36 \pm 67$ \\
\hline Gross margin livestock (1000 ETB/ha/year) & $92 \pm 241$ & $83 \pm 213$ \\
\hline Distance from market (walking hours) & $0.7 \pm 0.5$ & $1.2 \pm 0.8$ \\
\hline Market share (\%) & $66 \pm 24$ & $8 \pm 121$ \\
\hline Crop-livestock ratio (CLS) (-) & $0.5 \pm 0.3$ & $0.6 \pm 0.4$ \\
\hline
\end{tabular}

${ }^{\mathrm{a}} 1000$ ETB (Ethiopian Birr) $=43$ USD (January 2018)

${ }^{\mathrm{b}}$ Large standard deviation reflects large variation in characteristics among the farms.

${ }^{\mathrm{c}}$ NFI seems the sum of GMs, because some farms have no fixed costs and others have very small fixed costs and these made the average NFI almost equal to sum of the average GMs.

\subsubsection{N allocation impacts}

Mean CLS significantly differed between MC-LS farms with crop-oriented $\mathrm{N}$ allocation $(\mathrm{M}=0.79, \mathrm{SD}=0.20, \mathrm{n}=12)$ and $\mathrm{MC}-\mathrm{LS}$ farms with livestock-oriented $\mathrm{N}$ allocation $(\mathrm{M}=0.19$, $\mathrm{SD}=0.23, \mathrm{n}=8)$ at 0.05 level of significance $(\mathrm{t}=6.13, \mathrm{df}=18, \mathrm{p}<0.05)$ in Addis Ababa. Similarly, mean CLS significantly differed between MC-LS farms with crop-oriented $\mathrm{N}$ allocation $(\mathrm{M}=0.88, \mathrm{SD}=0.15, \mathrm{n}=12)$ and farms with livestock-oriented $\mathrm{N}$ allocation $(\mathrm{M}=0.17, \mathrm{SD}=0.16$, $\mathrm{n}=10)$ at 0.05 level of significance $(\mathrm{t}=10.67, \mathrm{df}=18, \mathrm{p}<0.05)$ in Jimma (Table 3.4). Marketed $\mathrm{N}$ inputs were much higher in Addis Ababa than in Jimma, and $\mathrm{N}$ inputs were much higher in farms with livestock-oriented $\mathrm{N}$ allocation than in farms with crop-oriented $\mathrm{N}$ allocation (Table 3.4). MC-LS farms with livestock-oriented $\mathrm{N}$ allocation had four to five times more $\mathrm{N}$ input than MC-LS farms with crop-oriented N allocation. In Addis Ababa, PNB was 38 and $288 \mathrm{~kg}$ $\mathrm{N}^{-1}$ year $^{-1}$ for farms with crop-oriented $\mathrm{N}$ allocation and livestock-oriented $\mathrm{N}$ allocation, respectively. In Jimma, PNB was 3 and $191 \mathrm{~kg} \mathrm{~N} \mathrm{ha}^{-1}$ year $^{-1}$ for MC-LS farms with croporiented $\mathrm{N}$ allocation and livestock-oriented $\mathrm{N}$ allocation (Table 3.4).

Mean NUE both at system level and animal level was higher in farms with crop-oriented N allocation than in farms with livestock-oriented $\mathrm{N}$ allocation in both study areas (Table 3.4). Mean NRI was relatively low in Addis Ababa; $11 \%$ in farms with crop-oriented $\mathrm{N}$ allocation and $9 \%$ in farms with livestock-oriented $\mathrm{N}$ allocation. In Jimma, NRI was $43 \%$ in farms with crop-oriented $\mathrm{N}$ allocation and $26 \%$ in farms with livestock-oriented $\mathrm{N}$ allocation (Table 3.4). 
Table 3.4 Mean N flows and income variables and standard deviation for MC-LS farms with crop (C) oriented and livestock (LS) oriented $\mathrm{N}$ allocation in Addis Ababa and Jimma

\begin{tabular}{|c|c|c|c|c|}
\hline \multirow{3}{*}{$\mathrm{N}$ flows and income variables } & \multicolumn{4}{|c|}{$\mathrm{N}$ allocation } \\
\hline & \multicolumn{2}{|c|}{ Addis Ababa $(\mathrm{n}=20)$} & \multicolumn{2}{|c|}{ Jimma $(n=22)$} \\
\hline & $\begin{array}{l}\text { C oriented } \\
(\mathrm{n}=12)\end{array}$ & $\begin{array}{l}\text { LS oriented } \\
(\mathrm{n}=8)\end{array}$ & $\begin{array}{l}\text { C oriented } \\
(\mathrm{n}=12)\end{array}$ & $\begin{array}{l}\text { LS oriented } \\
(\mathrm{n}=10)\end{array}$ \\
\hline Crop-livestock ratio $(\mathrm{kg} \mathrm{N} / \mathrm{kg} \mathrm{N})$ & $0.79 \pm 0.20$ & $0.19 \pm 0.23$ & $0.88 \pm 0.15$ & $0.17 \pm 0.16$ \\
\hline $\mathrm{N}$ inputs $\left(\mathrm{kg} \mathrm{N} \mathrm{ha}^{-1}\right.$ year $\left.^{-1}\right)$ & $106 \pm 38$ & $436 \pm 434^{\mathrm{a}}$ & $43 \pm 57$ & $232 \pm 272$ \\
\hline $\mathrm{N}$ outputs $\left(\mathrm{kg} \mathrm{N} \mathrm{ha}^{-1}\right.$ year $\left.^{-1}\right)$ & $68 \pm 62$ & $148 \pm 158$ & $40 \pm 73$ & $41 \pm 37$ \\
\hline Partial $\mathrm{N}$ balance $\left(\mathrm{kg} \mathrm{ha}^{-1}\right.$ year $\left.^{-1}\right)$ & $38 \pm 67$ & $288 \pm 283$ & $3 \pm 99$ & $191 \pm 242$ \\
\hline $\mathrm{N}$ use efficiency farm level (\%) & $64 \pm 51$ & $34 \pm 58$ & $93 \pm 389$ & $18 \pm 91$ \\
\hline $\mathrm{N}$ use efficiency animal level (\%) & $29 \pm 19$ & $24 \pm 17$ & $19 \pm 17$ & $11 \pm 9$ \\
\hline $\mathrm{N}$ recycling index $(\%)$ & $11 \pm 19$ & $9 \pm 22$ & $43 \pm 32$ & $26 \pm 27$ \\
\hline Net farm income (1000 ETB/ha/year) & $105 \pm 125$ & $214 \pm 366$ & $52 \pm 91$ & $199 \pm 284$ \\
\hline
\end{tabular}

${ }^{\mathrm{a}}$ Large standard deviation in rows reflect large variation in $\mathrm{N}$ flows and income variables within the MC-LS farms of Addis Ababa and Jimma.

CLS ratio was significantly related to $\mathrm{N}$ flows in MC-LS farms and explained 40 to $43 \%$ variance in $\mathrm{N}$ input, $0-30 \%$ variance in $\mathrm{N}$ output and $42-43 \%$ variance in PNB (Table 3.5 ). The NFI of MC-LS farms was also significantly related to CLS ratio in both study areas (Table 3.5). Farms with livestock-oriented $\mathrm{N}$ allocation had on average two to four times higher NFI than farms with crop-oriented $\mathrm{N}$ allocation (Table 3.4). However, the variation in NFI among farms within both cities was enormous (Figure 3.3).

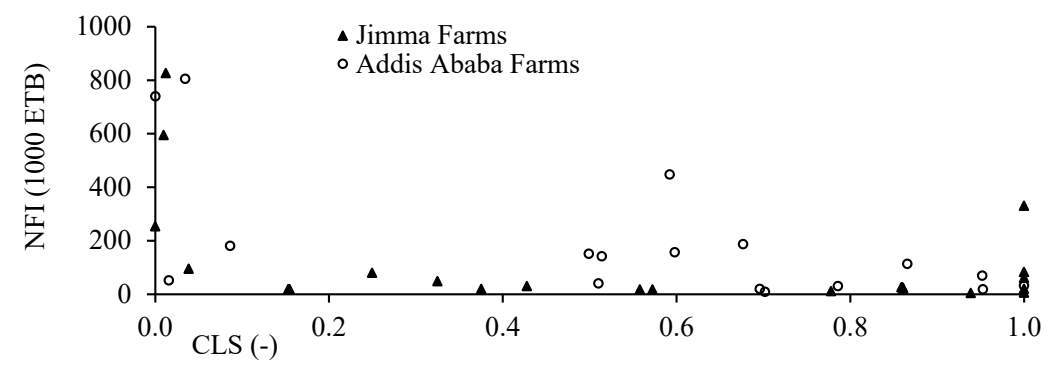

Figure 3.3 Net farm income (NFI) variations and relations with CLS (N allocation) in MC-LS farms of Addis Ababa and Jimma.

Table 3.5 Summary of Linear Regression Analyses for relations between $\mathrm{N}$ allocation (CLS) and

$\mathrm{N}$ flows and net farm income (NFI) of peri-urban MC-LS farms in Addis Ababa $(\mathrm{N}=20)$ and Jimma $(\mathrm{N}=22)$

\begin{tabular}{|c|c|c|c|c|c|c|c|c|c|}
\hline \multirow[t]{2}{*}{ Variable } & & \multicolumn{4}{|c|}{ Addis Ababa } & \multicolumn{4}{|l|}{ Jimma } \\
\hline & & IN & ON & PNB & NFI & IN & $\mathrm{ON}$ & PNB & NFI \\
\hline \multirow[t]{3}{*}{ CLS } & $\beta$ & $-0.66^{* *}$ & $-0.55^{*}$ & $-0.65^{* *}$ & $-0.72^{* *}$ & $-0.63^{* *}$ & $-0.01^{\mathrm{ns}}$ & $-0.65^{* *}$ & $-0.46^{*}$ \\
\hline & $R^{2}$ & 0.43 & 0.30 & 0.43 & 0.52 & 0.40 & 0 & 0.42 & 0.21 \\
\hline & $F$ & $13.73^{* *}$ & $7.6^{*}$ & $13.06^{* *}$ & $19.87^{* *}$ & $12.83^{* *}$ & $0.003^{\mathrm{ns}}$ & $14.39^{* *}$ & $5.38^{*}$ \\
\hline
\end{tabular}

$\beta=$ Beta; ${ }^{\text {ns }}=$ non significant difference $(P>0.05) ;{ }^{*}=$ significant difference at $P<0.05$ and $^{* *}=$ significant difference at $P<0.01, \mathrm{IN}=\mathrm{N}$ input, $\mathrm{ON}=\mathrm{N}$ output, $\mathrm{PNB}=$ Partial $\mathrm{N}$ balance 


\subsubsection{Correlation analysis among $\mathbf{N}$ flows and farm income indicators}

In Addis Ababa, $\mathrm{N}$ output, partial $\mathrm{N}$ balance (PNB), gross margin of livestock (GML) and net farm income (NFI) were positively correlated to total $\mathrm{N}$ input (Table 3.6). PNB was positively correlated to GML and NFI. In Jimma, NFI was positively related to GML, N input, and PNB. $\mathrm{N}$ recycling index (NRI) was negatively correlated to $\mathrm{N}$ input, $\mathrm{N}$ output, $\mathrm{PNB}, \mathrm{GML}$ and NFI (Table 3.7).

Table 3.6 Pearson correlations among N flows and income indicators for MC-LS farms in Addis Ababa peri-urban areas

\begin{tabular}{llllllll}
\hline & IN & ON & PNB & NRI & GMC & GML & NFI \\
\cline { 2 - 7 } N input (IN) (kg/ha/year) & 1.00 & $.88^{* *}$ & $.97^{* *}$ & -.28 & -.13 & $.97^{* *}$ & $.94^{* *}$ \\
N output (ON) (kg/ha/year) & & 1.00 & $.73^{* *}$ & -.35 & .19 & $.84^{* *}$ & $.89^{* *}$ \\
Partial N balance (PNB) (kg N/ha/year) & & & 1.00 & -.21 & -.39 & $.87^{* *}$ & $.77^{* *}$ \\
N recycling index (NRI) (\%) & & & & 1.00 & -.20 & -.18 & -.23 \\
Gross margin of crops (GMC) (ETB) & & & & & 1.00 & -.05 & .24 \\
Gross margin of livestock (GML) (ETB) & & & & & & 1.00 & $.96^{* *}$ \\
Net farm income (NFI) (ETB) & & & & & & 1.00 \\
\hline
\end{tabular}

$*=$ Correlation is significant at the 0.05 level of significance

$* *=$ Correlation is significant at the 0.01 level of significance

Table 3.7 Pearson correlations among $\mathrm{N}$ flows and income indicators for MC-LS farms in Jimma peri-urban areas

\begin{tabular}{llllllll}
\hline & IN & ON & PNB & NRI & GMC & GML & NFI \\
\cline { 2 - 7 } N input (IN) (kg/ha/year) & 1.00 & .28 & $.96^{* *}$ & $-.56^{* *}$ & -.21 & $.86^{* *}$ & $.80^{* *}$ \\
N output (ON) (kg/ha/year) & & 1.00 & -.00 & $-.50^{*}$ & $.80^{* *}$ & .35 & $.61^{* *}$ \\
Partial N balance (PNB) (kg N/ha/year) & & & 1.00 & $-.43^{*}$ & $-.46^{*}$ & $.79^{* *}$ & $.66^{* *}$ \\
N recycling index (NRI) (\%) & & & & 1.00 & -.24 & $-.46^{*}$ & $-.54^{* *}$ \\
Gross margin of crops (GMC) (ETB) & & & & & 1.00 & -.19 & .13 \\
Gross margin of livestock (GML) (ETB) & & & & & & 1.00 & $.95^{* *}$ \\
Net farm income (NFI) (ETB) & & & & & & & 1.00 \\
\hline
\end{tabular}

$*=$ Correlation is significant at the 0.05 level of significance

$* *=$ Correlation is significant at the 0.01 level of significance

\subsubsection{Sensitivity analysis of NUE and N recycling at farm system level}

At a low NUE (5\%) at animal level, system level NUE of MC-LS farms will likely range between 13 and 17\%, while at high NUE (35\%) at animal level, it may range between 37 and $51 \%$, depending also on the CLS ratio (Figure 3.4). Farm system NUE is much higher in MCLS farms with crop-oriented $\mathrm{N}$ allocation; for example, at CLS ratio $=0.8$, system level NUE will range between 31 to $56 \%$ at a low NUE (5\%) at animal level, while it may range between 38 and $65 \%$ at a high NUE (35\%) at animal level (Figure 3.4b). The estimated mean NUE at animal level was $29 \%$ for crop oriented and $24 \%$ for livestock-oriented MC-LS farms in Addis Ababa and 19\% for crop oriented and 11\% for livestock-oriented MC-LS farms in Jimma (Table 3.4). The relatively high NUE at animal level in Addis Ababa reflects probably that farmers may tend to overestimate the milk yield per cow per year compared to literature data. This could be attributed to the absence of proper monitoring and farm record keeping as 
observed in field data collection. Further, the estimated NUE at system level for livestockoriented farms were 34 and 18\%, respectively (Table 3.4). These values match with a relatively low recovery of manure $\mathrm{N}$ and a low utilization of manure and fertilizer $\mathrm{N}$, i.e., similar to option 1 in Table 3.2 .

Improvements in system level NUE will differ with N allocation (CLS) (Figure 3.4). MC-LS farms with livestock-oriented $\mathrm{N}$ allocation $(\mathrm{CLS}=0.2)$ and a modest NUE $(20 \%)$ at animal level may improve the current system level NUE up to about $35 \%$ and to about $50 \%$ when NUE at animal level is $35 \%$ (Figure $4 \mathrm{a}$ ). MC-LS farms with crop-oriented $\mathrm{N}$ allocation (CLS=0.8), may improve the system level NUE up to 50 to $65 \%$ (Figure 3.4b). In MC-LS farms with livestock-oriented $\mathrm{N}$ allocation, OPT2 and OPT5 will equally give a high system level NUE as fertilizer $\mathrm{N}$ use is negligible (Figure 3.4a).
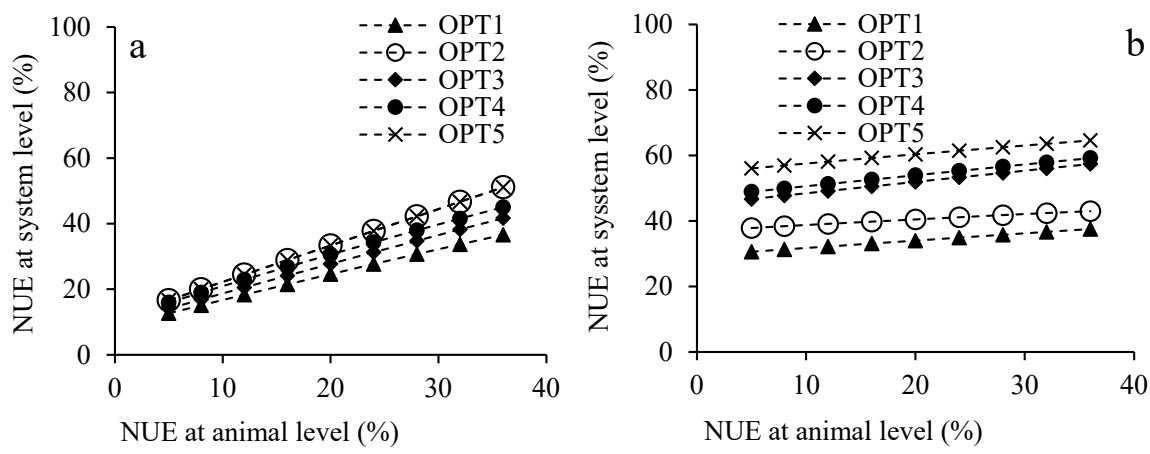

Figure 3.4 Relations between NUE at animal level and NUE at system level, calculated using various $\mathrm{N}$ management options related to internal $\mathrm{N}$ recycling and $\mathrm{N}$ recovery applied in crop and livestock production (a) for MC-LS farms with livestock-oriented N allocation at CLS: 0.2 and (b) for farms with crop-oriented $\mathrm{N}$ allocation at CLS: 0.8. Options (OPT) are explained in Table 3.2.

The improvement in system level NUE of MC-LS farms is reflected in N recycling index (NRI). Evidently, increasing NUE at animal level from 5 to $35 \%$ will decrease NRI because manure $\mathrm{N}$ production decreases with an increase in NUE at animal level, depending also on the CLS ratio (Figure 3.5). For livestock-oriented $\mathrm{N}$ allocation, there is a relatively large difference in NRI between options 1, 3 and 4 and options 2 and 5 (Figure 3.5a). This is mainly related to the differences in manure $\mathrm{N}$ recovery, and subsequent manure $\mathrm{N}$ utilization. In options 2 and 5 , it is assumed that all urine and faeces are collected, and that only $30 \%$ of the excreted $\mathrm{N}$ will be lost before application of manure to crop land. In contrast, urine collection is negligible and hence $\mathrm{N}$ losses are high (70\%) in options 1,3 , and 4 . The differences in urine (and faeces) collection have a large effect on NRI when CLS ratio is low (Figure 3.5a).

The mean NRI was much higher in Jimma than in Addis Ababa (Table 3.4). The mean NRI of Jimma is somewhat at the upper range of values presented in Figure 3.5, while the mean NRI value of Addis Ababa is at the lower range of values in Figure 3.5. The relatively high NRI 
values in Jimma are also the result of the low $\mathrm{N}$ input; conversely, the relatively low NRI in Addis Ababa reflects a relatively high $\mathrm{N}$ input (Table 3.4).
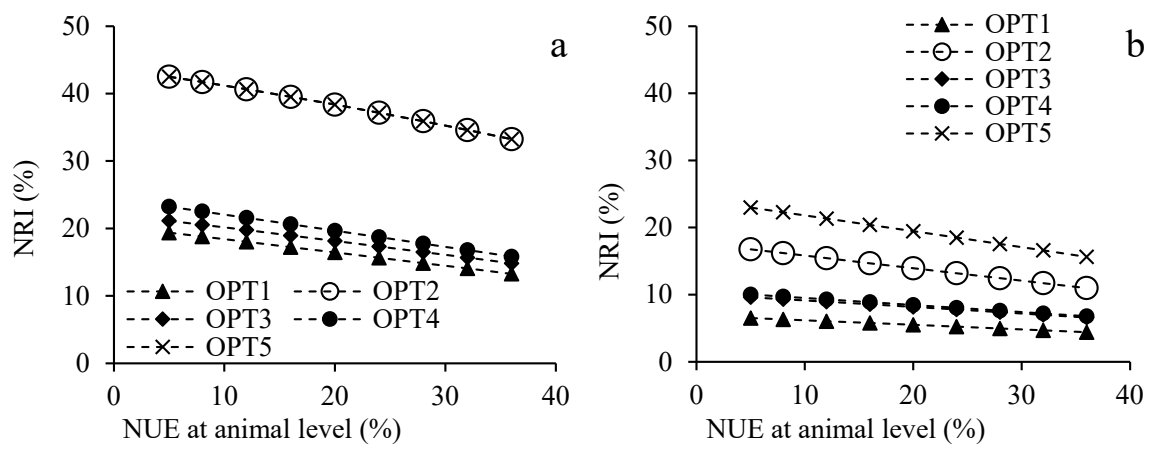

Figure 3.5 Relations between N recycling index (NRI) and NUE at animal level, calculated using N management options related to $\mathrm{N}$ recovery applied in crop and livestock production (a) for MC-LS farms with livestock-oriented $\mathrm{N}$ allocation at CLS: 0.2 and (b) for MC-LS farms with crop-oriented N allocation at CLS: 0.8. Options (OPT) are explained in Table 2.

\subsection{Discussion}

\subsubsection{Effects of $\mathbf{N}$ allocation}

The crop-livestock ratio (CLS) differed greatly between MC-LS farms in both study areas (Table 3. 4), and enabled us to differentiate MC-LS peri-urban farms into MC-LS farms with crop-oriented $\mathrm{N}$ allocation and MC-LS farms with livestock-oriented $\mathrm{N}$ allocation. MC-LS farms with livestock-oriented $\mathrm{N}$ allocation had higher $\mathrm{N}$ inputs, PNB, and NFI than croporiented MC-LS farms. Livestock oriented farms mostly used confinement-based feeding and purchased a significant fraction of the feed. Clearly, the CLS indicator has a large diagnostic value for characterizing MC-LS farms.

The differences observed in $\mathrm{N}$ allocation in MC-LS farms are related in part to resource constraints such as shortage of land, crop residue and capital (Tadesse et al., 2018), which creates internal competition within a farm. With an increase in animal output, crop residues are becoming limited resources in MC-LS farms, which creates pressure and trade-offs (Valbuena et al., 2015). The system configuration with the highest purchasing power ensues from this competition, and decisions about investments in $\mathrm{N}$ inputs for either crop or livestock compartments within a farm is dictated accordingly. Homann-Kee Tui et al. (2015), reported that nutrient resources in crop production and livestock husbandry are often limited, and create short and long-term trade-offs in nutrient allocation.

Mean CLS was negatively related to NFI, because livestock-oriented MC-LS farms (CLS < 0.5 ) allocated more external $\mathrm{N}$ input to their livestock compartment and had increased their 
productivity and hence increased their NFI. Conversely, livestock-oriented MC-LS farms had higher NFI and imported more external N input that resulted in lower CLS (Table 3.4 and 3.5). Accordingly, MC-LS farms with a low CLS (0.2) had two to four times more NFI than farms with high CLS (0.8) (Table 3.4). Hence, the economic performance of the livestock oriented MC-LS farms was rather similar to the specialized livestock farms in the urban and peri-urban environments of Addis Ababa and Jimma (Tadesse et al., 2018). Conversely, the performance of the crop-oriented MC-LS farms was rather similar to the specialized crop farms. Crop oriented MC-LS farms still keep livestock, because animals perform important non-market roles. Tarawali et al. (2011), indicated that up to $40 \%$ of the benefits from livestock, especially cattle keeping came from non-market, intangible benefits, mostly insurance, financing and draught power.

MC-LS farms with crop-oriented $\mathrm{N}$ allocation had relatively low PNB, for two reasons. First, the available crop residues were mainly used as biofuel and feed, animal manures were used as biofuel and not for soil fertility amendment. As a result, crop yields were relatively low. Second, because of the low crop yields farmers had low income and were unable to purchase fertilizers. According to Homann-Kee Tui et al. (2015), feeding crop residues to livestock is often accompanied with using manure as fuel, at the expense of soil fertility amendment. Hence, the need for energy by households is at the cost of soil fertility management (Alvarez et al., 2014), also because ashes are not well utilized. Negash et al. (2017), reported that application of crop residues and manure for soil fertility management is limited because of competitive use for household energy.

MC-LS farms with crop-oriented $\mathrm{N}$ allocation had higher $\mathrm{N}$ use efficiency than MC-LS farms with livestock-oriented $\mathrm{N}$ allocation (Table 3.4). This finding is in agreement with the general observation that manure $\mathrm{N}$ is vulnerable to various loss processes and hence that system level NUE is usually much less in livestock production than in crop production systems (Goulding et al., 2008). The internal nutrient recycling is considered one of the most beneficial features of MC-LS farming systems (Rufino et al., 2009a; Rufino et al., 2006). However, N recycling was relatively low (9-43\%) in the MC-LS farms across the study areas (Table 3.4) and did not differ much between crop oriented and livestock-oriented MC-LS farms. This low N recycling could be due to the challenge that animal manure and crop residues are contested for fuel in peri-urban areas of Addis Ababa and Jimma. Negash et al. (2017), reported that the use of manure for fuel instead of soil fertility amendment has reduced agricultural gross domestic production (GDP) of Ethiopia by $\sim 7 \%$, via soil degradation and low crop yields. Correlation analyses revealed negative correlations between NRI and $\mathrm{N}$ input, $\mathrm{N}$ output, PNB and NFI (Table 3.7). This suggests that farms with relatively high external $\mathrm{N}$ imports had low $\mathrm{N}$ recycling; crop residues and manures were used for fuel or were wasted, and not used for soil fertility management. About $85 \%$ of the crop residues are used for either livestock feed or energy in Ethiopia (Agegnehu and Amede, 2017), while manures including urine and ashes are not effectively collected, stored and reutilized (Negash et al., 2017).

Available labor and lack of regulations are also major barriers for the effective collection and recycling of animal manures. Use of inorganic $\mathrm{N}$ fertilizers requires much less labor than 
careful manure management. Yu et al. (2017), reported that farmers became more willing to use inorganic fertilizers than the labor-intensive crop residues and manures, the latter often requires composting before application. Clearly, the cost of labor for manure management is one of the barriers for $\mathrm{N}$ recycling. On the other hand, there is lack of formal requirements to collect and store manures properly prior to application to land. Many livestock farms have no leak-tight stables and manure storage systems, and much of the liquid fraction thus simply disappears and not actively applied to crop lands.

Interestingly, $\mathrm{N}$ output and NFI are negatively related to NRI (Table 3.7). This suggests that the effects of external $\mathrm{N}$ inputs are much greater than the effects of recycled N. Further, it indicates that the costs of external inputs are relatively low relative to the gain in output. The purchase of concentrate feed and fertilizers adds also to the status of the farmers; the use of inorganic fertilizers instead of organic amendments is considered an indication for the wealth of the household, and the best way to increase agricultural productivity. Besides, government policies are encouraging the use of inorganic fertilizers as reported in Howard et al. (2003).

\subsubsection{Sensitivity analyses of NUE at farm system level}

System level NUE greatly depends on NUE at animal level, manure N loss, and manure and fertilizer $\mathrm{N}$ recovery in harvested plant biomass (Liu et al., 2017b). Our analyses indicate that the farm system level NUE also depends on the CLS ratio (Figure 3.4). System level NUE of livestock-oriented MC-LS farms are likely in the range of 10 to $40 \%$, depending on the NUE at animal level and the utilization of manure and fertilizers (if any). System level NUE of crop oriented MC-LS farms are likely in the range of 30 to 60\% (Figure 3.4). de Klein et al. (2017) reported a whole-farm NUE of grassland-based dairy farms in the range of 10 to $65 \%$, and Liu et al. (2017b) arrived at a maximum possible system level NUE of MC-LS farms of $70 \%$. Alvarez et al. (2014), reported system level NUE of 2 to $50 \%$ depending on manure management and concentrate supply in MC-LS systems in Madagascar.

Improvements in system level NUE depend in part on N allocation within MC-LS farms (Figure 3.4). In MC-LS farms with livestock oriented N allocation (CLS: 0.2) improvements in system level NUE are firstly related to improvements in NUE at animal level and secondly through the improved recovery and utilization of manure N. MC-LS farms with crop oriented $\mathrm{N}$ allocation (CLS: 0.8 ) gain more from the improvements in the recovery of fertilizer and manure $\mathrm{N}$ than from improvements in NUE at animal level (Figure 3.4b). Powell and Rotz (2015), indicated that reductions in dietary crude protein to reduce $\mathrm{N}$ losses from dairy farms, may decrease the fertilizer $\mathrm{N}$ value of manure and manure $\mathrm{N}$ use efficiency. Similar to the improvement in NUE at animal level, a shift in dairy cow diets from alfalfa silage to lowprotein corn silage significantly reduced concentrations of inorganic $\mathrm{N}$ in the manure, which have profound impacts on the $\mathrm{N}$ recycling and manure $\mathrm{N}$ availability to crops (Powell and Rotz, 2015). The relatively high mean NUE at animal level in Addis Ababa; 29\% in crop oriented and $24 \%$ in livestock-oriented MC-LS farms (Table 3.4), is likely the result of high-yielding dairy cows and modest levels of crude protein in the ration (13-15\%), but overestimating milk 
yields by farmers cannot be excluded. The relatively low mean NUE at animal level in Jimma; $19 \%$ in crop oriented and $11 \%$ in livestock-oriented MC-LS farms (Table 3.4), is likely the result of a genetically low yielding cows and low-quality feed. In agreement, Rufino et al. (2006) reported that for high yielding dairy cows, increasing the dietary $\mathrm{N}$ increases the milk yield only when $\mathrm{N}$ is more limiting than the energy requirements of the cow and provided that the amino acid composition of the diet meets the requirements for milk production. But for poor quality feed that doesn't provide the amino acid composition required for milk production, greater dietary $\mathrm{N}$ intake simply results in a greater excretion of $\mathrm{N}$ and reduces NUE. The large difference in mean NUE at animal level in Addis Ababa and Jimma indicate that different strategies: the genetic improvement of livestock breeds; feed quality improvement and precision feeding; NUE and N recycling enhancing measures (exchange of crop residues and manure between crop and livestock activities within and between farms), and provision of alternative and low cost energy sources for satisfaying the fuel demand of the farming families will be needed to improve the performance of livestock oriented MC-LS farms. Similarly, Shikuku et al. (2017) suggested promotion of improved feeding strategies and introduction of more efficient breeds of livestock to achieve increased productivity of MC-LS systems. Therefore, both feed quality and the genetic basis of the herd will have to be improved first in livestock-oriented MC-LS farms in Jimma.

\subsection{Conclusions}

We introduced a quantitative indicator (CLS ratio) as a first attempt to characterize the relative allocation of external $\mathrm{N}$ inputs to the soil/crop and livestock compartments in MC-LS farms, and to relate CLS ratio to NUE, PNB and farm income. Accordingly, our results have the following important insights and policy implications.

$>$ CLS ratio is proved to be a key indicator for the characterization of MC-LS farms; as farm income (NFI), PNB and NUE at farm level are all related to CLS ratio.

$>$ Lower CLS ratio was associated with large external $\mathrm{N}$ input allocation to the livestock than the crop compartment and thus MC-LS farms with livestock oriented $\mathrm{N}$ allocation had four to five times higher $\mathrm{N}$ input, more than seven times higher PNB and two to four times higher NFI than farms with crop oriented $\mathrm{N}$ allocation.

$>\mathrm{N}$ allocation significantly varied between MC-LS farms in both study areas, indicating that MC-LS farms are diverse and that competetion occurs between crop and livestock compartments within a farm.

$>$ Sensitivity analyses suggests that through promotion of improved manure management and introduction of more efficient livestock breeds, the NUE of MC-LS farms can be improved by 20 to $25 \%$ and $\mathrm{N}$ recycling by 10 to $20 \%$ over the current condition.

Therefore, to improve the environmental and economic performance of MC-LS peri-urban farms in Ethiopia, (1) NUE and N recycling enhancing measures including livestock feed quality improvement, exchange of crop residues and manure between crop and livestock compartments within and between farms, and provision of alternative and low cost energy sources for satisfying the fuel demand of the farming families; in combination with (2) improving the NUE at animal level through animal breeding for the genetic improvement of 
livestock breeds and precision animal feeding; should be put in practice. Due to the extreme shortage of land in urban and peri-urban areas, future research should incorporate the effects of changing land allocation as a key aspect in the sensitivity analysis of the impacts of improved livestock breeding and feeding strategies of MC-LS farms.

\section{Chapter 3}

\section{References:}

Agegnehu G., and Amede T. (2017) Integrated Soil Fertility and Plant Nutrient Management in Tropical Agro-Ecosystems: A Review. Pedosphere 27: 662-680.

Alvarez S., Rufino M.C., Vayssières J., Salgado P., Tittonell P., Tillard E., Bocquier F. (2014) Whole-farm nitrogen cycling and intensification of crop-livestock systems in the highlands of Madagascar: An application of network analysis. Agric Syst 26: 25-37.

Banerjee A., Chakrabarty M., Rakshit N., Mukherjee J., Ray S. (2017) Indicators and assessment of ecosystem health of Bakreswar reservoir, India: An approach through network analysis. Ecological Indicators 80: 163-173.

Blömmel M., Homann-Kee Tui S., Valbuena D., Duncan A.J., Herrero M. (2013) Biomass in crop-livestock systems in the context of the livestock revolution. Secheresse 24: 330339. doi: $10.1684 / \mathrm{sec} .2013 .0403$

Cassidy E.S., West P.C., Gerber J.S., Foley J.A. (2013) Redefining agricultural yields: from tones to people nourished per hectare. Environ Res Lett 8. doi:10.1088/17489326/8/3/034015

de Klein C.A.M., Monaghan R.M., Alfaro M., Gourley C.J.P., Oenema O., Powell J.M. (2017) Nitrogen performance indicators for dairy production systems. Soil Research 55: 479488.

Duncan A.J., Tarawali1 S.A., Thorne P.J., Valbuena D., Descheemaeker K., Homann-Kee Tui S. (2013) Integrated crop-livestock systems-a key to sustainable intensification in Africa. Tropical Grasslands-Forrajes Tropicales 1: 202-206.

Goulding K., Jarvis S., Whitmore A. (2008) Optimizing nutrient management for farm systems. Philos Trans R Soc Lond B Biol Sci 363: 667-680.

Gupta V., Rai P.K., Risam K.S. (2012) Integrated Crop-Livestock Farming Systems: A Strategy for Resource Conservation and Environmental Sustainability. Indian Research Journal of Extension Education, Special Issue 2: 49-54.

Haile Mariam A., Adugna A. (2011) Migration and urbanization in Ethiopia: Addressing the spatial imbalance. In: Teller C. and Haile Mariam A. (eds.). The demographic transition and development in Africa: The unique case of Ethiopia. New York: Springer: 145165. doi:10.1007/978-90-481-8918-2-8.

Homann-kee Tui S., Valbuena D., Masikati P., Descheemaeker K., Nyamangara J., Claessens L., Erenstein O., van Rooyen A., Nkomboni D. (2015) Economic trade-offs of biomass use in crop-livestock systems: Exploring more sustainable options in semi-arid Zimbabwe. Agric Syst 134: 48-60. 
Howard J., Crawford E., Kelly V., Demeke M., Jeje J.J. (2003) Promoting high-input maize technologies in Africa: the Sasakawa-Global 2000 experience in Ethiopia and Mozambique. Food Policy 28: 335-348.

Kindu M., Duncan A.J., Valbuena D., Gérard B., Dagnachew L., Mesfin B., Gedion J. (2014) Intensification of Crop-Livestock Farming Systems in East Africa: A Comparison of Selected Sites in the Highlands of Ethiopia and Kenya. In: Vanlauwe B., van Asten P., Blomme G. (eds) Challenges and Opportunities for Agricultural Intensification of the Humid Highland Systems of SSA. Springer, Cham p. 19-28. doi.org/10.1007/978-3319-07662-1-2.

Liu Q., Wang J., Bai Z., Ma L., Oenema O. (2017) Global animal production and nitrogen and phosphorus flows. Soil Research 55: 451-462.

Marton S., Zimmermann A., Kreuzer M., Gaillard G. (2016) Comparing the environmental performance of mixed and specialised dairy farms: the role of the system level analysed. Journal of Cleaner Production 124: 73-83.

Negash D., Abegaz A., Smith J.U., Araya H., Gelana B. (2017) Household energy and recycling of nutrients and carbon to the soil in integrated crop-livestock farming systems: a case study in Kumbursa village, Central Highlands of Ethiopia. GCB Bioenergy 9: 1588-1601.

Powell J.M., Rotz C.A. (2015) Measures of nitrogen use efficiency and nitrogen loss from dairy production systems. J Environ Qual 44: 336-344.

Rufino M.C., Hengsdijk H., Verhagen A. (2009) Analysing integration and diversity in agroecosystems by using indicators of network analysis. Nutr Cycl in Agroecosyst 84: 229247.

Rufino M.C., Rowe E.C., Delve R.J., Giller K.E. (2006) Nitrogen cycling efficiencies through resource-poor African crop-livestock systems. Agriculture, Ecosystems and Environment 112: 261-282.

Ryschawy J., Choisis N., Choisis.J.P., Joannon A., Gibon A. (2012) Mixed crop-livestock systems: an economic and environmental-friendly way of farming? Animal 6: 17221730.

Satterthwaite D., Mcgranahan G., Tacoli C. (2010) Urbanization and its implications for food and farming. Philos Trans R Soc Lond B Biol Sci 365: 2809-2820.

Shikuku K.M., Valdivia R.O., Paul B.K., Mwongera C., Winowiecki L., Läderach P., Herrero M., Silvestri S. (2017) Prioritizing climate-smart livestock technologies in rural Tanzania: A minimum data approach. Agricultural Systems 151: 204-216.

Sneessens I., Veysset P., Benoit M., Lamadon A., Brunschwig G. (2016) Direct and indirect impacts of crop-livestock organization on mixed crop-livestock systems sustainability: a model-based study. Animal 10: 1911-1922.

Strokal M., Ma L., Bai Z., Luan S., Kroeze C., Oenema O., Velthof G., Zhang F. (2016) Alarming nutrient pollution of Chinese rivers as a result of agricultural transitions. Environ Res Lett 11. doi:10.1088/1748-9326/11/2/024014.

Tadesse S.T., Oenema O., van Beek C., Ocho F.L. (2018) Diversity and nutrient balances of urban and peri-urban farms in Ethiopia. Nutrient Cycling in Agroecosystems 111: 118. 
Tarawali S., Herrero M., Descheemaeker K., Grings E., Blümmel M. (2011) Pathways for sustainable development of mixed crop livestock systems: Taking a livestock and propoor approach. Livestock Science 139: 11-21.

Thornton P.K. (2010) A Review: Livestock production: recent trends, future prospects. Phil Trans R Soc 365: 2853-2867.

Tittonell P., van Wijk M.T., Rufino M.C., Vrugt J.A., Giller K.E. (2007) Analyzing trade-offs in resource and labor allocation by smallholder farmers using inverse modelling techniques: A case-study from Kakamega district, western Kenya. Agric Syst 95: 7695.

Valbuena D., Tui S.H., Erenstein O., Teufel N., Duncan A., Abdoulaye T., Swain B., Mekonen K., Germaine I., Gerard B. (2015) Identifying determinants, pressures and trade-offs of crop residue use in mixed smallholder farms in Sub-Saharan Africa and South Asia. Agric Syst 134: 107-118.

van Beek C.L., Meerburg B.G., Schils R.L.M., Verhagen J., Kuikman P.J. (2010) Feeding the world's increasing population while limiting climate change impacts: linking N2O and $\mathrm{CH} 4$ emissions from agriculture to population growth. Environ science and policy 13: 89-96.

van Beek C.L., Onduru D.D., Gachimbi L.N., de Jager A. (2009) Farm nutrient flows of four farmer field schools in Kenya. Nutr Cycl in Agroecosyst 83: 63-72.

Vlaming J., van Beek C.L., Heinen M., van Duivenbooden N. (2012) MonQIt monitoring for quality improvement MonQIt basic user manual. www.monqi.org.

Wang H.J., Huang B., Shi X.Z., Darilek J.L., Yu D.S., Sun W.X., Zhao Y.C., Chang Q., Öborn I. (2008) Major nutrient balances in small-scale vegetable farming systems in periurban areas in China. Nutr Cycl Agroecosyst 81: 203-218.

Wang F., Wang Z., Kou C., Ma Z., Zhao D. (2016) Responses of Wheat Yield, Macro- and Micro-Nutrients, and Heavy Metals in Soil and Wheat following the Application of Manure Compost on the North China Plain. PloS one 11: 1-18.

Yu C., Xiao Y., Ni S. (2017) Changing patterns of urban-rural nutrient flows in China: driving forces and options. Science Bulletin 62: 83-91.

Zasada I. (2011) Multifunctional peri-urban agriculture-A review of societal demands and the provision of goods and services by farming. Land Use Policy 28: 639-648. 


\section{CHAPTER 4}

\section{Manure recycling from urban livestock farms for closing the urban-rural nutrient loops}

This chapter is published as:

Tadesse ST, Oenema O, Van Beek C, Ocho FL (2021a) Manure recycling from urban livestock farms for closing the urban-rural nutrient loops. Nutr Cycl Agroecosyst 119:51-67. doi.org/10.1007/s10705020-10103-8. Supplementary information, figure S1 and table S1 can be found in the link https://staticcontent.springer.com/esm/art\%3A10.1007\%2Fs10705-020-101038/MediaObjects/10705_2020_10103_MOESM1_ESM.docx. 


\begin{abstract}
Rapid urbanization in developing countries is attracting urban livestock farming, which is associated with feed nutrient imports and manure nutrient accumulations. Here, we report on manure nutrients (N, P and K) production on urban livestock farms in Addis Ababa and Jimma in Ethiopia, and estimate manure recovery on these farms and its recycling in urban, peri-urban and rural crop farms. Estimates were based on data from farm surveys, statistics, literature and model calculations. Urban livestock farms had on average 13 tropical livestock units and positive $\mathrm{N}, \mathrm{P}$ and $\mathrm{K}$ balances. Urban crop farms had negative $\mathrm{N}$ and $\mathrm{K}$ balances, and did not use manure from urban livestock farms. We estimated that $0.5-2.6 \mathrm{Gg} \mathrm{N}, 0.2-0.8 \mathrm{Gg} \mathrm{P}$ and 0.93.7 Gg K can be collected in manure from the 5,200 urban livestock farms in Addis Ababa year $^{-1}$, and can be recycled in crop land. Two manure allocation strategies were explored: balanced $\mathrm{P}$ fertilization and balanced $\mathrm{N}$ fertilization. The former allowed greater precision in matching nutrient supply to demand, and was associated with greater manure transport and distribution, up to rural areas. Manure recycling has several benefits: synthetic fertilizer savings (75-300 million Ethiopian Birr year ${ }^{-1}$ for Addis Ababa), soil fertility replenishment, and reductions in water pollution. However, there are various cultural, educational and institutional barriers for manure recycling. We argue that more quantitative data and scenario analyses are needed for deliberative decision making and for exploring more sustainable development pathways of urban livestock farms, re-connected to crop farms via manure recycling.
\end{abstract}

Key words: Balanced fertilization; fertilizer saving; manure management; nutrition security; pollution 


\subsection{Introduction}

Global population is projected to reach 9-10 billion by 2050 (FAO, 2017) and 68\% of the population is projected to be urban (UN, 2019). These changes are accompanied by fast growing food demand and dietary transitions in urban areas (Satterthwaite, 2017). Most of the food for urban people is imported from rural areas (Jones et al., 2013), but significant amounts are provided also by urban and peri-urban farms (Roessler et al., 2016b). Urban and peri-urban agriculture (UPA) contributes to the livelihood of urban dwellers, providing jobs, income and food security, especially in developing countries (Chihambakwe et al., 2018; Khumalo and Sibanda, 2019; Mugisa et al., 2017). Thebo et al. (2014) reported that $11 \%$ of the global area of irrigated cropland was urban irrigated cropland, and $4.7 \%$ of global rain-fed cropland was urban. UPA farms mainly supply perishable vegetables and animal products to urban areas, due to the proximity to and high prices in urban markets (Djurfeldt, 2015; Mugisa et al., 2017).

Significant amounts of nutrients are embedded in agricultural products that are transported from rural and peri-urban areas to urban areas (Lin et al., 2014; Zhu et al., 2017). This transfer contributes to nutrient accumulation in urban areas (Yu et al., 2017; Zhu et al., 2017) and to nutrient depletion in rural areas, especially when animal manure and human wastes from urban and peri-urban areas are not recycled back to rural areas (Goulding et al., 2008; Jones et al., 2013). The accumulation of manure and human waste in urban and peri-urban areas contributes to a range of unwanted human health and environmental effects (Herrero et al., 2018).

The 'circular economy' is a response to the inefficient use and management of resources in our current linear socio-economic systems (Michelini et al., 2017). It aims at more sustainable development through increased recycling. Alike, nutrient recovery from animal manure and human waste in urban and peri-urban areas and recycling in rural areas has direct environmental benefits (Neo, 2010; Rao et al., 2017), and may replace synthetic fertilizers and thus reduce the costs, emissions and pollutions associated with the production and use of synthetic fertilizers (Buckwell and Nadeu, 2016; Yu and Wu, 2018). Also, recycled nutrients may reduce the dependency of countries on imports of fertilizers (Smits and Woltjer, 2018), and are thought to have a vital role in achieving Sustainable Development Goals on food and nutrition security, clean water and sanitation, sustainable cities and life below water and on land (Zhu et al., 2017).

Although recycling of animal manures and household wastes has several advantages, the willingness and incentives for recycling manures and wastes back to crop land are still limited in developing countries (van Beek et al., 2016). For instance, less than $10 \%$ of the animal manures and crop residues available to smallholder farmers in Ethiopia were applied to soils (Nigussie et al., 2015), despite net nutrient depletion due to nutrient withdrawal with harvested crops, erosion and leaching, and limited applications of inorganic and organic fertilizers (van Beek et al., 2016). Some dung cakes are collected and used for building and cooking purposes, and some excrements deposited in animal confinements are partially recovered and applied to cropland, but most of the animal depositions are not recovered and recycled. There is lack of 
knowledge and information, and there are cultural barriers for recycling wastes. Moreover, governmental policies and regulations for manure collection and recycling are lacking (Komakech, 2014; Tadesse et al., 2018) or incipient (Herrero et al., 2018) in developing countries. This leads to accumulation of nutrients in urban and peri-urban areas, and to pollution and eutrophication of rivers and lakes (Yu et al., 2017).

Tackling nutrient accumulation in urban livestock farms and nutrient depletion in rural crop farms simultaneously, through recycling of manures from urban areas in rural areas, is an opportunity and a necessity (Goulding et al., 2008). Recycling of agricultural wastes is in line with the FAO model for sustainable intensification of crop production "Save and grow" (Pergola et al., 2017), and represents an important contribution to the circular economy at regional level (Pergola et al., 2017). However, the amounts of nutrients in manure that can be recycled from urban farms to rural farms, and the associated fertilizer savings are currently not well known. The purpose of this study was threefold: (i) to estimate the amounts of manure nutrients that can be recycled from urban livestock farms to crop farms in urban, peri-urban and rural areas, (ii) to explore strategies for increased manure recycling, and (iii) to estimate fertilizer saving and reductions in nutrient pollutions in urban, peri-urban and rural areas, in Addis Ababa and Jimma in Ethiopia.

\subsection{Materials and methods}

\subsubsection{Study site and farm characteristics}

Addis Ababa (Finfinnee) is the capital city of Ethiopia (Figure S1); it had a total population of 3.4 million in 2015 and an annual population growth rate of $3.8 \%$ (Feyisa et al., 2016). Jimma is one of the secondary cities in Ethiopia and the commercial center of the Southwestern part of the country. It had a total population of 0.2 million in 2014 and an annual population growth rate of 3\% (Abrha et al., 2015). The two cities differ in their bio-physical characteristics and agro-ecology. Addis Ababa has ten sub-cities; most of the UPA farms are found in five sub cities (Abdalla et al., 2011; Tadesse et al., 2019) and these were selected for this study. In Jimma, all eight urban woredas (districts) within the city were selected (Table S1). Rural woredas near the two cities were included (Table S1). Although the selected rural woredas are situated in the highlands and designated as models for the Agricultural Growth Program (AGP) woredas by the Ethiopian government, due to their potential for agricultural production (Eyasu and van Beek 2015, Tefera et al. 2012), the smallholder farms are not as productive as claimed (van Beek et al., 2016). Most UPA farms are mixed crop-livestock farms, but the relative contributions of crops, vegetables and livestock to farm income differs greatly. Farm income is much higher on farms with focus on livestock production and vegetables, than on farms with focus on crops (Tadesse et al., 2018). Most farms in the rural areas are also mixed croplivestock farms (Table S1), but crop production is here the most important activity; livestock are kept for draught power supporting crop production and for family milk production (Mukai, 2018). 


\subsubsection{Concept of nutrient cycling between UPA farms and rural farms}

Urban, peri-urban and rural areas differ in population density, built-up areas, infrastructures and key economic activities (Allen, 2003; Opitz et al., 2015). Makita et al. (2010) distinguished a city center with urban, peri-urban and rural areas around the center (Figure 4.1). The city center is dominated by business buildings, high income residential areas and houses with high fences, and basically has no agriculture. Urban areas are densely populated built-up areas, with locally intensive farming activities. Peri-urban areas are urban-rural transition areas, with a high population increase, mainly through migration, and with space for agriculture. Rural areas have low population increase and often little economic activities; most people depend on agriculture, especially in developing countries. The width of the city center and urban and periurban areas greatly differ between cities and tend to increase over time when cities grow. Large cities have diameters of 30-50 km, and often exploit peri-urban and rural resources for urban uses (Simon, 2008). However, the ecological, economic and social functions of rural areas are of mutual importance for urban, peri-urban and rural areas (Allen, 2003).

City centers and urban, peri-urban and rural areas are often an asymmetrical, uneven and multidimensional continuum. There are no distinct lines separating the center from peri-urban, urban and rural settings, but often a slow zone of change exists (Lupindu, 2017). For the purpose of our study, we distinguished three zones around the city centers of Addis Ababa and Jimma (Figure 4.1). Addis Ababa had a city center of $527 \mathrm{~km}^{2}$ with a diameter of roughly $26 \mathrm{~km}$ in 2017 (Terfa et al., 2019), and Jimma a city center of $100 \mathrm{~km}^{2}$ with a diameter of roughly 11 $\mathrm{km}$ in 2017 (Abebe et al., 2019). Following the concept of Zhu et al. (2017) and the approaches of Makita et al. (2010) and Opitz et al. (2015), we assigned three zones (A, B and C) around the city centers; $10 \mathrm{~km}$ wide zones around the city center of Addis Ababa, and $5 \mathrm{~km}$ wide zones around the city center of Jimma. Zone A is considered the 'urban periphery' (intra-urban). Zone $\mathrm{B}$ is the peri-urban area (urban-rural interface), and zone $\mathrm{C}$ is the rural area.

In each zone we identified the type, number and size of the farms on the basis of data statistics, literature and farms survey. In total, there were 5200 UPA livestock farms in Addis Ababa (Tamiru and Amza, 2017) and 500 in Jimma (according to the agriculture office of the city). Tabor (2013) studied the land use of Addis Ababa and its fringes using Landsat images of 1973, 1986, 2000 and 2011 and collected land use data in 2011 for ground truthing (Table 4.1). Zewdie et al. (2018) also assessed the land use of Addis Ababa in 2015 using Landsat images of 1984, 1995, 2003 and 2014. The images were acquired during the dry seasons to better differentiate agricultural cropland from natural vegetation, and attained an accuracy level of $87 \%$ for land use classification (Zewdie et al., 2018). They estimated that the studied districts in Addis Ababa had an area of 122,100 ha, including 55,400 ha agricultural land (Admasu and Runnström, 2017). Abrha et al. (2015) studied the land use of Jimma city using remote sensing and attained $84 \%$ accuracy level of land use classification. The studied districts in Jimma had an area of 12,000 ha, including 7,908 ha agricultural land.

We assumed that manure transport and recycling will occur in the following sequence. (i) Manure disposal is based on the N, P and K demand of the crops; the nutrient element that 
meets the demand per crop/field first, determines the manure application rate (see also section 4.2.5). (ii) The demand is satisfied (saturated) first in the zone where the manure has been produced, to minimize transport distances (Rodionov and Nakata, 2011). (iii) Excess manure from zone $\mathrm{A}$ is transported to peri-urban crop farms in zone $\mathrm{B}$, until also here all remaining demand has been satisfied. (iv) Remaining surpluses from zone A (and possibly from zone B) are then transported to rural crop farms in zone $\mathrm{C}$.

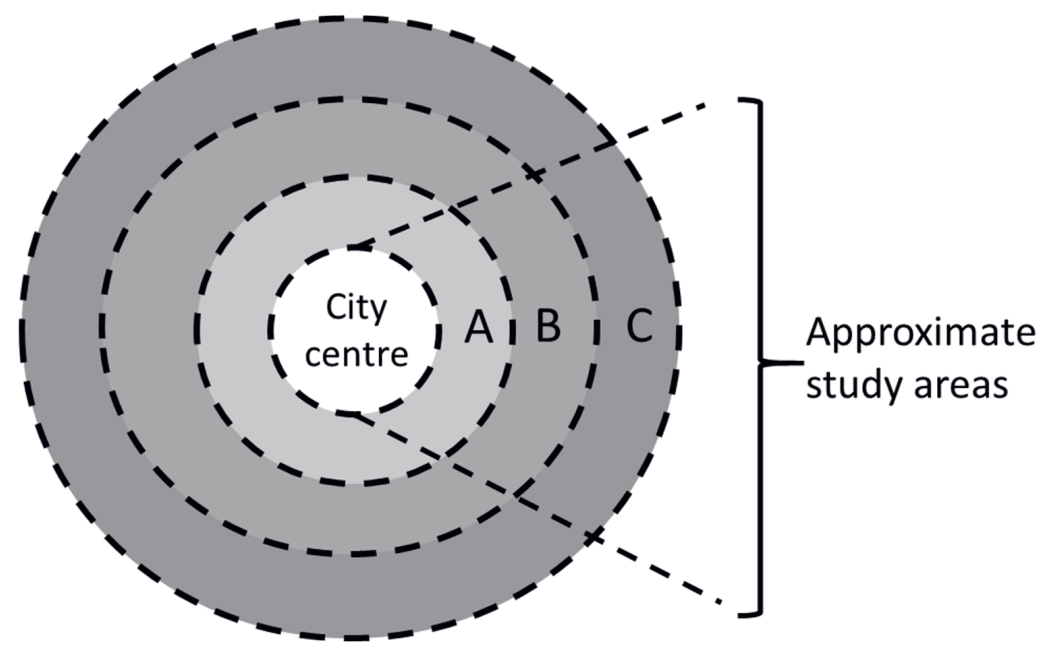

Figure 4.1 Conceptual configuration of the studied cities, with a city center, and an urban zone (A), a peri-urban zone (B) and a rural zone (C) around the city center. The radius of the city center was estimated at $13 \mathrm{~km}$ and the width of each zone at $10 \mathrm{~km}$ for Addis Ababa, and at 6 and $5 \mathrm{~km}$ for Jimma, respectively. After Mohamed and Worku (2019) and Abrha et al. (2015). 
Table 4.1 Land use and main crops in the studied districts of urban (A), peri-urban (B) and rural (C) areas of Addis Ababa and Jimma. For comparison, also data for a further rural area zone is presented. Note that total areas do match with areas of full circles

\begin{tabular}{|c|c|c|c|c|c|c|}
\hline \multirow{7}{*}{$\begin{array}{l}\text { Addis } \\
\text { Ababa }\end{array}$} & \multirow{2}{*}{$\begin{array}{l}\text { Land use } \\
\text { types (ha) }\end{array}$} & \multicolumn{4}{|c|}{ Distances of zones from city centers $(\mathrm{km})$} & \multirow[t]{2}{*}{ Total } \\
\hline & & $A(0-10)$ & $B(10-20)$ & $C(20-30)$ & $30-40$ & \\
\hline & Built-up & 32,462 & 16,632 & 3,368 & 2,738 & 55,200 \\
\hline & Agriculture & 658 & 24,539 & 24,398 & 5,805 & \multirow[t]{2}{*}{55,400} \\
\hline & $\begin{array}{l}\text { Main crops } \\
\text { cultivated }\end{array}$ & $\begin{array}{l}\text { Vegetables } \\
\text { (e.g., tomato, } \\
\text { potato), beans }\end{array}$ & $\begin{array}{l}\text { Vegetables, } \\
\text { beans, barley, } \\
\text { wheat, pulses }\end{array}$ & $\begin{array}{l}\text { Barley, teff, } \\
\text { wheat, } \\
\text { pulses }\end{array}$ & $\begin{array}{l}\text { Barley, teff, } \\
\text { wheat, high land } \\
\text { oilseeds, pulses }\end{array}$ & \\
\hline & Vegetation & 3,688 & $5,681.3$ & $1,738.4$ & 392.3 & \multirow{2}{*}{$\begin{array}{l}11,500 \\
122,100\end{array}$} \\
\hline & Total & 36,808 & $46,852.3$ & $29,504.4$ & $8,935.3$ & \\
\hline \multirow{7}{*}{ Jimma } & \multirow{2}{*}{$\begin{array}{l}\text { Land use } \\
\text { types (ha) }\end{array}$} & \multicolumn{4}{|c|}{ Distances of zones from city centers $(\mathrm{km})$} & \multirow[t]{2}{*}{ Total } \\
\hline & & $A(0-5)$ & $B(5-10)$ & $C(10-15)$ & $15-20$ & \\
\hline & Built-up & 632 & 628 & 0 & 0 & 1,260 \\
\hline & Agriculture & 992 & 2,478 & 2,544 & 1,894 & \multirow{2}{*}{7,908} \\
\hline & $\begin{array}{l}\text { Main crops } \\
\text { cultivated }\end{array}$ & $\begin{array}{l}\text { Vegetables } \\
\text { (e.g., tomato, } \\
\text { potato), beans }\end{array}$ & $\begin{array}{l}\text { Vegetables, } \\
\text { beans, maize, } \\
\text { barley, wheat }\end{array}$ & $\begin{array}{l}\text { Barley, teff, } \\
\text { wheat, } \\
\text { coffee }\end{array}$ & $\begin{array}{l}\text { Teff, sorghum } \\
\text { maize, wheat, } \\
\text { coffee, spices }\end{array}$ & \\
\hline & Vegetation & 908 & 1399 & 428 & 97 & 2,832 \\
\hline & Total & 2,532 & 4,505 & 2,972 & 1,991 & 12,000 \\
\hline
\end{tabular}

Sources: (Abrha et al., 2015; Tadesse et al., 2018, 2019; Zewdie et al., 2018)

Note that the three zones defined for the envisaged recycling are indicated in italic.

\subsubsection{Data collection}

In 2014, a total of 299 UPA farms (Addis Ababa:175, Jimma:124) were visited and examined; the diversity among the farms and the N, P and $\mathrm{K}$ balances have been reported by Tadesse et al. (2018). In 2016, a random selection of 40 livestock farms (Addis Ababa: 20, Jimma: 20) and 38 crop farms (Addis Ababa: 19, Jimma: 19) out of the 299 UPA farms were revisited and examined in more detail. In 2016 we also visited 164 farms in rural areas: 72 from five rural woredas (districts) linked to Addis Ababa, and 92 from five rural woredas linked to Jimma. Farmers were interviewed face-to-face and data was collected using the standardized questionnaire of MonQIt (Monitoring for Quality Improvement toolbox) (van Beek et al., 2016; van Beek et al., 2010).

MonQIt is a toolbox for monitoring and evaluating the management and performance of smallholder farms (www.monqit.com; Smaling et al. 2013; Vlaming 2012). The information about farm management and farm activities is obtained from the farmer using the MonQIt questionnaire (see the supplementary information). The following data were collected: farm characteristics, crop and animal husbandry practices, nutrient management (inputs via fertilizer, manure, crop residues; outputs via harvested crops and animal products), sales, and input and output prices. The data were entered into the MonQIt model, which also contains a data base with information on nutrient contents of products, soil data and conversion factors. The MonQIt model produces the following performance indicators: NPK balances at plot, activity and farm levels, and gross margin and net farm income (van Beek et al., 2016). 
The 78 UPA farms and 164 farms in the rural area were visited twice in 2016. In the first round, farm characteristics and nutrient input flows (purchased mineral fertilizers, organic fertilizers, seeds, feed and concentrates) were quantified at the beginning of the cropping season. In the second round, output flows (harvested crop products, residues and animal products, and sales) leaving the farm were quantified after harvest. Data on nutrient $(\mathrm{N}, \mathrm{P}$ and $\mathrm{K})$ contents of harvested crop products, crop residues, milk and manure were obtained from literature (Alvarez et al., 2014; Negash et al., 2017; Wang et al., 2016) and included in the MonQIt database.

\subsubsection{Quantification of farm level nutrient balances}

The N, P and K input and output flows were estimated as follows (Bekunda and Manzi, 2003; Nigussie et al., 2015):

$$
F=\sum_{i=1}^{n} Q i D i C i
$$

Where, $\mathrm{F}$ is the flow of $\mathrm{N}, \mathrm{P}$ or $\mathrm{K}\left(\mathrm{kg} \mathrm{ha}^{-1} \mathrm{yr}^{-1}\right)$; $\mathrm{n}$ is the number of nutrient inputs and outputs in a year; $\mathrm{Q}$ is the quantity of inputs or outputs $\left(\mathrm{kg} \mathrm{ha}^{-1} \mathrm{yr}^{-1}\right)$; D is the dry matter content of inputs or outputs (\%); C is N, P or K content of inputs or outputs (\%).

Nutrient (N, P and K) balances were calculated per farm as the difference between total input and total output flows of $\mathrm{N}, \mathrm{P}$ and $\mathrm{K}$, annually (Eq. 4.2; unit: $\mathrm{kg} \mathrm{ha}^{-1} \mathrm{yr}^{-1}$ ):

$$
N B=[(I N 1+\cdots+I N 4)-(O U T 1+\cdots+\text { OUT5 })]
$$

Where, NB is nutrient balance $\left(\mathrm{kg} \mathrm{ha}^{-1} \mathrm{yr}^{-1}\right)$; IN1 and IN2 are farmer managed inputs (fertilizer, compost, concentrate, organic feed), IN3 and IN4 are atmospheric deposition and biological N fixation, respectively, and OUT1 and OUT2 are outputs in harvested crop, residue, milk and manure and OUT3, OUT4 and OUT5 are losses via leaching, gaseous emissions and erosion, respectively (van Beek et al., 2016).

Net farm income (NFI) was derived from gross margin (GM) and the total fixed costs (FIXCOST) of the farm (Eq. 4.3; unit: Ethiopian Birr $\mathrm{yr}^{-1}$ ).

$$
\mathrm{NFI}=\mathrm{GM}-\mathrm{FIXCOST}
$$

Where, GM is calculated as the difference between the gross value of all outputs and the variable costs of all inputs of the farm, over a year. FIXCOST is the total fixed costs of the farm (e.g. depreciation costs of barns, tools, and rent of the land). 


\subsubsection{Assessment of manure recycling}

In total, there were about 5200 urban livestock farms in Addis Ababa (Tamiru and Amza 2017) and 500 LS farms in Jimma (according to the information obtained from the urban agriculture office of the city) in 2016. In general, these farms had dairy cattle, on average 13.5 tropical livestock units (TLU) in Addis Ababa and 11.5 TLU in Jimma (Table 4.2). Manure production was calculated according to equation 4.4.

\section{Manure $N, P$ and $K$ production per zone $(\mathrm{kg})$ $=$ Number of farms per zone $*$ average TLU per farm$$
\text { * average manure } N, P, K \text { per } T L U
$$

Estimates of manure production per animal, in $\mathrm{kg} \mathrm{N}, \mathrm{P}$ and $\mathrm{K}$ per tropical livestock unit (TLU; 1 TLU has a live weight of $250 \mathrm{~kg}$ ), were based on literature data and farm surveys. Snijders et al. (2009) arrived at average manure production of $9.43 \mathrm{~kg} \mathrm{TLU}^{-1}$ day $^{-1}$ (fresh weight), with a dry matter content of $35 \%$. This translates to an annual manure production of $25 \mathrm{~kg} \mathrm{~N}, 6.7 \mathrm{~kg}$ $\mathrm{P}$, and $33 \mathrm{~kg} \mathrm{~K}$ per TLU, when assuming mean contents of $2.1 \% \mathrm{~N}, 0.56 \% \mathrm{P}$, and $2.75 \% \mathrm{~K}$ (Negash et al., 2017). Sheldrick et al. (2003) estimated the global manure N, P and K production based on linear relationships between slaughtered weight and $\mathrm{N}, \mathrm{P}$ and $\mathrm{K}$ production. Using their model, we arrive at an annual manure production of $28 \mathrm{~kg} \mathrm{~N}, 5.6 \mathrm{~kg} \mathrm{P}$ and $25 \mathrm{~kg} \mathrm{~K}$ per TLU (with a slaughtered weight for cattle of $140 \mathrm{~kg} \mathrm{TLU}^{-1}$ ). Snijders et al. (2009) reviewed variations in cattle manure composition and management practices in East Africa. Variations in nutrient content of manures were large and associated with differences in (i) feed rations, (ii) collection, storage and processing of excreta, and (iii) additions of bedding materials. Further, excretion rates were related to milk production; they indicated that milk production ranged from $<500 \mathrm{~kg}$ to more than $4500 \mathrm{~kg} \mathrm{cow}^{-1} \mathrm{year}^{-1}$, and that manure $\mathrm{N}$ production ranged from 30 to $90 \mathrm{~kg} \mathrm{cow}^{-1}$ year $^{-1}$. Our survey data also revealed large variability in cattle productivity and management between livestock farms; based on these observations we decided to use three sets of manure $\mathrm{N}, \mathrm{P}$, and $\mathrm{K}$ production coefficients: 25,5 and $25 \mathrm{~kg}$ $\mathrm{cow}^{-1}$ year $^{-1}$ for cows producing $<500 \mathrm{~kg}$ milk year ${ }^{-1} ; 50,10$ and $50 \mathrm{~kg} \mathrm{cow}^{-1}$ year $^{-1}$ for cows producing 500 to $3000 \mathrm{~kg}$ milk year ${ }^{-1}$, and 75,15 and $75 \mathrm{~kg} \mathrm{cow}^{-1}$ year $^{-1}$ for cows producing $>3000 \mathrm{~kg}$ milk year ${ }^{-1}$, respectively. Hence, N: P: K ratios (5:1:5) in excreta were kept constant. Further, we assumed that young stock (calves and heifers) produced on average $25 \%$ of the amounts of adult cows.

Manure recovery fractions (RF) are defined as the fractions of $\mathrm{N}, \mathrm{P}$ and $\mathrm{K}$ excreted in manures that are recovered for recycling. These fractions mainly depend on the manure collection efficiency and nutrient losses during storage. Snijders et al. (2009) estimated nutrient losses for different manure collection and storage systems for East African conditions. Losses were highest for open kraal/boma (30-100\% for urine N; 10-50\% for faeces N, 20-30\% for faeces $\mathrm{P}$ and $10-80 \%$ for $\mathrm{K}$ ) and least for leak tight and covered slurry pits (20-40\% for urine $\mathrm{N} ; 5-10 \%$ for faeces N, 3-10\% for faeces P and 5-15\% for K). Liu et al. (2017a) estimated recovery fractions of $0.3-0.7$ for $\mathrm{N}$ and 0.5 to $0.95 \%$ for $\mathrm{P}$ as function of housing systems and manure 
management. A recovery fraction of 0.3 indicates poor manure management whereas 0.95 indicates best manure management (Liu et al., 2017a). Rufino et al. (2007) reported a recovery of 0.4 for $\mathrm{N}$ in manure stored in open piles in Kenya. Bicudo (2009) and Sutton (1994) reported recovery fractions of 0.4 to 0.6 for $\mathrm{N}, 0.6$ to 0.8 for $\mathrm{P}$ and 0.5 to 0.7 for $\mathrm{K}$ in manures from open manure storages. Most livestock farms in Addis Ababa and Jimma have no leak-tight stables and manure storage systems (Tadesse et al., 2019), but recovery fractions have not been quantified. Based on this data, we used two sets of recovery fractions for $\mathrm{N}, \mathrm{P}$ and $\mathrm{K}$ in manure: 0.3 and 0.5 for $\mathrm{N}, 0.6$ and 0.8 for $\mathrm{P}$, and 0.5 and 0.7 for $\mathrm{K}$. The recyclable amounts of $\mathrm{N}, \mathrm{P}$ and $\mathrm{K}$ in manure were estimated from the manure $\mathrm{N}, \mathrm{P}$ and $\mathrm{K}$ production per zone and the recovery fractions.

Total N, P and K demands were estimated from crop-specific N, P and K demands ( $\mathrm{kg} \mathrm{ha}^{-1}$ year $^{-1}$ ) per zone, crop type-specific nutrient losses (van Beek et al., 2016), and surface areas of the crops per zone, using MonQIt (van Beek et al., 2016). The fraction of the N, P and K demand covered through recycling per zone depended on the specific crop demands, the manure composition and manure application strategy. Two variants of manure application strategies were explored: (i) balanced $\mathrm{P}$ application, i.e., manure application defined by $\mathrm{P}$ demand (and assuming top-up $\mathrm{N}$ and/or $\mathrm{K}$ fertilization through other nutrient sources), and (ii) balanced $\mathrm{N}$ fertilization, i.e., manure application defined by $\mathrm{N}$ demand (and thus accepting over fertilization of $\mathrm{P}$ and/or $\mathrm{K}$ ).

\subsubsection{Data analysis}

Data obtained from MonQIt model on nutrient flows, balances, farm characteristics (e.g., TLU and farm size) and economic performance indicators (e.g., net farm income) per farm were subjected to ANOVA to test for significant differences in nutrient flows and balances, net farm income and farm characteristics among urban, peri-urban and rural farms. Mean values of nutrient flows and balances were compared using LSD value at 5\%. For all data analysis, we used SPSS statistical software version 23.

\subsection{Results}

\subsubsection{Farm characteristics}

Farms were relatively small, with on average 0.6 to 2.6 ha of land per household (Table 4.2). Households had on average 7 family members, both in the urban and rural areas. Urban livestock farms had on average 11.5 to 13.5 tropical livestock units (TLU) per farm, peri-urban farms 5 to 6 and rural farms 6 to 7 TLU. Urban crop farms also had 4 to 7 TLU per farm; basically, these were mixed crop-livestock farms. Livestock density was high; in Addis Ababa urban livestock farms had $>22$ TLU per ha of land and in Jimma 16 TLU per ha. Even the rural farms in both Addis Ababa and Jimma had a livestock density of 2 to 3 TLU per ha. 
Farm characteristics were slightly different between the farms in Addis Ababa and Jimma regions (Table 4.2). UPA farms in Addis Ababa had more livestock, less crop area and less crops per farm than the UPA farms in Jimma. As a result, UPA farms in Addis Ababa had on average a higher net farm income than the UPA farms in Jimma (Table 4.2).

Table 4.2 Characteristics (means \pm standard deviations) of urban livestock (LS) and crop farms, and of peri-urban and rural farms in Addis Ababa and Jimma (2016 monitoring year)

\begin{tabular}{|c|c|c|c|c|c|c|c|c|}
\hline \multirow{3}{*}{ Characteristics } & \multicolumn{4}{|c|}{ Addis Ababa } & \multicolumn{4}{|l|}{ Jimma } \\
\hline & \multicolumn{2}{|l|}{ Urban } & \multirow{2}{*}{$\begin{array}{l}\text { Peri- } \\
\text { urban } \\
(\mathrm{n}=11)\end{array}$} & \multirow{2}{*}{$\begin{array}{l}\text { Rural } \\
(n=72)\end{array}$} & \multicolumn{2}{|l|}{ Urban } & \multirow{2}{*}{$\begin{array}{l}\text { Peri- } \\
\text { urban } \\
(\mathrm{n}=9)\end{array}$} & \multirow{2}{*}{$\begin{array}{l}\text { Rural } \\
(\mathrm{n}=92)\end{array}$} \\
\hline & $\begin{array}{l}\mathrm{LS} \\
(\mathrm{n}=20)\end{array}$ & $\begin{array}{l}\text { Crop } \\
(\mathrm{n}=8)\end{array}$ & & & $\begin{array}{l}\mathrm{LS} \\
(\mathrm{n}=20)\end{array}$ & $\begin{array}{l}\text { Crop } \\
(n=10)\end{array}$ & & \\
\hline $\begin{array}{c}\text { Number of HH } \\
\text { (household) } \\
\text { members }\end{array}$ & $7 \pm 3$ & $6 \pm 4$ & $6 \pm 3$ & $7 \pm 2$ & $5 \pm 2$ & $7 \pm 2$ & $7 \pm 2$ & $7 \pm 2$ \\
\hline $\begin{array}{c}\text { Ratio of female } \\
\text { to male } \mathrm{HH} \\
\text { head }(\mathrm{F}: \mathrm{M})\end{array}$ & $1: 6$ & $1: 3$ & $1: 4.5$ & $1: 6$ & $1: 4$ & $0: 10$ & $0: 9$ & $1: 12$ \\
\hline $\begin{array}{l}\text { Land size per } \\
\text { farm HH (ha) }\end{array}$ & $\begin{array}{l}0.6 \\
\pm 0.4\end{array}$ & $\begin{array}{l}1.7 \\
\pm 0.9\end{array}$ & $\begin{array}{l}1.7 \\
\pm 0.8 \\
\end{array}$ & $\begin{array}{l}2.0 \\
\pm 1.5\end{array}$ & $\begin{array}{l}0.7 \\
\pm 0.4 \\
\end{array}$ & $\begin{array}{l}1.5 \\
\pm 0.8\end{array}$ & $\begin{array}{l}1.4 \\
\pm 0.7\end{array}$ & $\begin{array}{l}2.6 \\
\pm 1.4\end{array}$ \\
\hline $\begin{array}{l}\text { Number of crops } \\
\text { per farm }\end{array}$ & $1 \pm 1$ & $6 \pm 1$ & $5 \pm 2$ & $3 \pm 1$ & $2 \pm 3$ & $7 \pm 2$ & $5 \pm 2$ & $6 \pm 2$ \\
\hline $\begin{array}{l}\text { Number of } \\
\text { livestock per } \\
\text { farm (TLU) }\end{array}$ & $\begin{array}{l}13.5 \\
\pm 9\end{array}$ & $\begin{array}{l}4 \\
\pm 7\end{array}$ & $\begin{array}{l}6 \\
\pm 3\end{array}$ & $\begin{array}{l}7 \\
\pm 4\end{array}$ & $\begin{array}{l}11.5 \\
\pm 7\end{array}$ & $\begin{array}{l}7 \\
\pm 5\end{array}$ & $\begin{array}{l}5 \\
\pm 2\end{array}$ & $\begin{array}{l}6 \\
\pm 3\end{array}$ \\
\hline 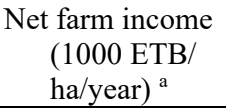 & $\begin{array}{l}527 \\
\pm 258\end{array}$ & $\begin{array}{l}117 \\
\pm 93\end{array}$ & $\begin{array}{l}84 \\
\pm 62\end{array}$ & $\begin{array}{l}20 \\
\pm 18\end{array}$ & $\begin{array}{l}474 \\
\pm 295\end{array}$ & $\begin{array}{l}35 \\
\pm 32\end{array}$ & $\begin{array}{l}60 \\
\pm 103\end{array}$ & $\begin{array}{l}11 \\
\pm 8\end{array}$ \\
\hline
\end{tabular}

\subsubsection{Farm level nutrient flows and balances}

Nutrient balances were significantly different $(P<0.05)$ among urban livestock farms and crop farms in urban, peri-urban and rural areas (Table 4.3). Crop farms had negative $\mathrm{N}$ and $\mathrm{K}$ balances, and positive $\mathrm{P}$ balances, in all three zones. This indicates soil $\mathrm{N}$ and $\mathrm{K}$ depletion and soil $\mathrm{P}$ accumulation. Positive $\mathrm{P}$ balances on crop were related to the use of subsidized diammonium phosphate (DAP) fertilizers. Note that the N, P and K outputs of crop farms include losses via leaching, erosion and denitrification. As a result, the estimated N/P ratios of the output ranged from 10 to as high as 40, and K/P ratios of the output ranged from 2 to 6 .

Positive N, P and K balances of livestock farms were related to the import of animal feed to the farm, and to the fact that only a small fraction ( 5 to $20 \%$ ) of the ingested feed N, P and K is exported in milk and meat. The remainder of the ingested feed $\mathrm{N}, \mathrm{P}$ and $\mathrm{K}$ is excreted in urine and faeces. Note that the output of N, P and K of livestock farms were not corrected for losses from manure storage systems in Table 4.3. The N, P and $\mathrm{K}$ output of urban livestock farms were higher in Addis Ababa than in Jimma, mainly because of the higher animal productivity and higher crop yields in Addis Ababa. We infer that significant amounts of surplus manures from urban livestock farms can be recycled to nearby crop farms. 
Table 4.3 Mean nutrient inputs, outputs and balances $\left(\mathrm{kg} \mathrm{ha}^{-1}\right.$ year $\left.{ }^{-1}\right)$ of urban livestock (LS) and crop farms, and peri-urban and rural crop farms in Addis Ababa and Jimma

\begin{tabular}{|c|c|c|c|c|c|c|c|c|}
\hline \multirow{3}{*}{ Variables } & \multicolumn{4}{|c|}{ Addis Ababa Farms } & \multicolumn{4}{|c|}{ Jimma Farms } \\
\hline & \multicolumn{2}{|l|}{ Urban } & \multirow{2}{*}{$\begin{array}{l}\text { Peri- } \\
\text { urban } \\
(\mathrm{n}=11)\end{array}$} & \multirow{2}{*}{$\begin{array}{l}\text { Rural } \\
(\mathrm{n}=72)\end{array}$} & \multicolumn{2}{|l|}{ Urban } & \multirow{2}{*}{$\begin{array}{l}\text { Peri- } \\
\text { urban } \\
(\mathrm{n}=9)\end{array}$} & \multirow{2}{*}{$\begin{array}{l}\text { Rural } \\
(\mathrm{n}=92\end{array}$} \\
\hline & $\begin{array}{l}\begin{array}{l}\text { LS } \\
(\mathrm{n}=20)\end{array}\end{array}$ & $\begin{array}{l}\text { Crop } \\
(n=8)\end{array}$ & & & $\begin{array}{l}\text { LS } \\
(\mathrm{n}=20)\end{array}$ & $\begin{array}{l}\text { Crop } \\
(n=10)\end{array}$ & & \\
\hline Nitrogen $(\mathrm{N})$ balance & $343^{\mathrm{a}}$ & $-81^{b}$ & $-43^{b}$ & $-49^{b}$ & $314^{\mathrm{a}}$ & $-41^{\mathrm{b}}$ & $-73^{b}$ & $-28^{\mathrm{b}}$ \\
\hline $\mathrm{N}$ input & $534^{\mathrm{a}}$ & $87^{\mathrm{b}}$ & $105^{\mathrm{b}}$ & $80^{\mathrm{b}}$ & $424^{\mathrm{a}}$ & $69^{\mathrm{b}}$ & $37^{\mathrm{b}}$ & $39^{c}$ \\
\hline $\mathrm{N}$ output & $191^{\mathrm{a}}$ & $168^{\mathrm{a}}$ & $148^{\mathrm{a}}$ & $129^{\mathrm{a}}$ & $110^{\mathrm{a}}$ & $110^{\mathrm{a}}$ & $110^{\mathrm{a}}$ & $67^{\mathrm{b}}$ \\
\hline Phosprous (P) balance & $53^{\mathrm{a}}$ & $6^{\mathrm{b}}$ & $24^{\mathrm{b}}$ & $14^{\mathrm{b}}$ & $54^{\mathrm{a}}$ & $14^{\mathrm{b}}$ & $3^{\mathrm{b}}$ & $10^{\mathrm{b}}$ \\
\hline $\mathrm{P}$ input & $82^{\mathrm{a}}$ & $23^{\mathrm{b}}$ & $30^{\mathrm{b}}$ & $17^{\mathrm{b}}$ & $57^{\mathrm{a}}$ & $18^{\mathrm{b}}$ & $12^{\mathrm{b}}$ & $13^{\mathrm{b}}$ \\
\hline P output & $29^{\mathrm{a}}$ & $17^{\mathrm{a}}$ & $6^{\mathrm{b}}$ & $3^{\mathrm{b}}$ & $3^{\mathrm{a}}$ & $4^{\mathrm{a}}$ & $9^{\mathrm{a}}$ & $3^{\mathrm{a}}$ \\
\hline Potassium (K) balance & $187^{\mathrm{a}}$ & $-79^{\mathrm{b}}$ & $-9^{\mathrm{b}}$ & $-11^{b}$ & $189^{\mathrm{a}}$ & $1^{\mathrm{b}}$ & $-8^{b}$ & $-1^{\mathrm{b}}$ \\
\hline $\mathrm{K}$ input & $280^{\mathrm{a}}$ & $24^{\mathrm{b}}$ & $22^{\mathrm{b}}$ & $6^{\mathrm{b}}$ & $194^{\mathrm{a}}$ & $17^{\mathrm{b}}$ & $12^{\mathrm{b}}$ & $5^{\mathrm{b}}$ \\
\hline K output & $93^{\mathrm{a}}$ & $103^{\mathrm{a}}$ & $31^{\mathrm{b}}$ & $17^{\mathrm{b}}$ & $5^{\mathrm{b}}$ & $16^{\mathrm{a}}$ & $20^{\mathrm{a}}$ & $6^{\mathrm{b}}$ \\
\hline
\end{tabular}

ANOVA was used to compare continuous variables and means were compared using LSD test.

Means with different letters within rows per city are significantly different.

Balances of $\mathrm{N}\left(F_{3,117}=65.2\right), \mathrm{P}\left(F_{3,117}=10.9\right)$ and $\mathrm{K}\left(F_{3,117}=14.7\right)$ at Addis Ababa and $\mathrm{N}\left(F_{3,127}=\right.$ 38.6), $\mathrm{P}\left(F_{3,127}=25.6\right)$ and $\mathrm{K}\left(F_{3,127}=41.8\right)$ at Jimma, all significantly differed at $p<0.05$ among 4 farm groups: urban livestock farms, urban, peri-urban and rural crop farms (2016 monitoring year).

\subsubsection{Potentials of manure nutrient recycling}

We estimated that $0.5-2.6 \mathrm{Gg} \mathrm{N}, 0.2-0.8 \mathrm{Gg} \mathrm{P}$ and $0.9-3.7 \mathrm{Gg} \mathrm{K}$ may be collected in manure from urban livestock farms in Addis Ababa and recycled to crop land per year (Table 4.4). The ranges reflect the uncertainty (roughly a factor 3 ) in the estimates due to the variation in $\mathrm{N}, \mathrm{P}$ and $\mathrm{K}$ excretion coefficients, and in $\mathrm{N}, \mathrm{P}$ and $\mathrm{K}$ recovery fractions (variants 1 to 6). The estimated quantities were more than one order of magnitude lower for Jimma: 0.04-0.22 Gg N, 0.02-0.07 Gg P and 0.07-0.30 Gg K (Table 4.4), because the size and the number of urban livestock farms were less in Jimma than in Addis Ababa.

Table 4.4 Amounts of recyclable N, P, and K in manure in Addis Ababa and Jimma urban regions, as function of variants (combinations of 3 sets of excretion coefficients and 2 sets of recovery fractions; see text)

\begin{tabular}{|c|c|c|c|c|c|c|c|c|c|c|}
\hline \multirow[t]{2}{*}{ Cities } & \multirow[t]{2}{*}{ Variant } & \multicolumn{3}{|c|}{$\begin{array}{l}\text { Excretion rates, } \\
\mathrm{kg} \mathrm{cow}^{-1} \mathrm{yr}^{-1}\end{array}$} & \multicolumn{3}{|c|}{$\begin{array}{c}\text { Recovery fraction, } \\
\% \\
\end{array}$} & \multicolumn{3}{|c|}{$\begin{array}{l}\text { Recyclable nutrients, } \\
\qquad \mathrm{Gg} \mathrm{yr}^{-1}\end{array}$} \\
\hline & & $\mathrm{N}$ & $\mathrm{P}$ & $\mathrm{K}$ & $\mathrm{N}$ & $\mathrm{P}$ & $\mathrm{K}$ & $\mathrm{N}$ & $\mathrm{P}$ & $\mathrm{K}$ \\
\hline \multirow[t]{6}{*}{ Addis Ababa } & 1 & 25 & 5 & 25 & 0.3 & 0.6 & 0.5 & 0.5 & 0.2 & 0.9 \\
\hline & 2 & 25 & 5 & 25 & 0.5 & 0.8 & 0.7 & 0.9 & 0.3 & 1.2 \\
\hline & 3 & 50 & 10 & 50 & 0.3 & 0.6 & 0.5 & 1.1 & 0.4 & 1.8 \\
\hline & 4 & 50 & 10 & 50 & 0.5 & 0.8 & 0.7 & 1.8 & 0.6 & 2.5 \\
\hline & 5 & 75 & 15 & 75 & 0.3 & 0.6 & 0.5 & 1.6 & 0.6 & 2.6 \\
\hline & 6 & 75 & 15 & 75 & 0.5 & 0.8 & 0.7 & 2.6 & 0.8 & 3.7 \\
\hline \multirow[t]{6}{*}{ Jimma } & 1 & 25 & 5 & 25 & 0.3 & 0.6 & 0.5 & 0.04 & 0.02 & 0.07 \\
\hline & 2 & 25 & 5 & 25 & 0.5 & 0.8 & 0.7 & 0.07 & 0.02 & 0.10 \\
\hline & 3 & 50 & 10 & 50 & 0.3 & 0.6 & 0.5 & 0.09 & 0.03 & 0.14 \\
\hline & 4 & 50 & 10 & 50 & 0.5 & 0.8 & 0.7 & 0.14 & 0.05 & 0.20 \\
\hline & 5 & 75 & 15 & 75 & 0.3 & 0.6 & 0.5 & 0.13 & 0.05 & 0.22 \\
\hline & 6 & 75 & 15 & 75 & 0.5 & 0.8 & 0.7 & 0.22 & 0.07 & 0.30 \\
\hline
\end{tabular}

$\mathrm{Gg}=$ gigagram $=1$ million $\mathrm{kg}$ 
Total N, P and K demands by crop-based farms were much smaller in the urban area than in the peri-urban and rural areas (Table 4.5). The mean N/P ratio of the demand was 7 and the mean $\mathrm{K} / \mathrm{P}$ ratio was 6 , with little differences between Addis Ababa and Jimma, and between zones A, B and C. Figure 4.2 presents the supply of manure N, P, and K from urban livestock farms relative to the demand of $\mathrm{N}, \mathrm{P}$ and $\mathrm{K}$ by crop-based farms in the three zones A, B and C, for six variants and two application strategies. The N/P ratios in the available manure ranged from 2.5 to 3.1, and the K/P ratio from 4.2 to 4.4 (Table 4.4), and were much lower than the $\mathrm{N} / \mathrm{P}$ and K/P ratios of the demand by the crop farms. As a result, the $\mathrm{N}$ and $\mathrm{K}$ demand by the crop was not matched by $\mathrm{N}$ and $\mathrm{K}$ supply by manure in the urban area, if manure application rates were determined by balanced $\mathrm{P}$ fertilization (Figure 4.2a). The same applies for the periurban and rural areas; in Addis Ababa there were three variants (4, 5 and 6) that supplied sufficient manure $\mathrm{P}$ from urban livestock farms to match the $\mathrm{P}$ demand in the peri-urban area. Conversely, there is a large oversupply of $\mathrm{P}$ and $\mathrm{K}$, if the $\mathrm{N}$ demand by the crop determines the manure application rates (Figure 4.2b). Note, there is also oversupply of $\mathrm{P}$ and $\mathrm{K}$ in the periurban area in variant 6 (and partly in variant 5), and there is no manure transport to the rural areas in the balanced $\mathrm{N}$ fertilization strategy.

Rather similar results were obtained for Jimma. For balanced $P$ fertilization, 5 of the 6 variants supplied sufficient manure $\mathrm{P}$ to meet the demand for $\mathrm{P}$ in the urban area (not shown). Variant 6 supplied also sufficient manure $\mathrm{P}$ to meet the demand for $\mathrm{P}$ in the peri-urban area, and also $40 \%$ of the $\mathrm{P}$ demand in the rural area, but demands for $\mathrm{N}$ and $\mathrm{K}$ were not matched in urban, peri-urban and rural areas. For balanced $N$ fertilization, 3 of the 6 variants (4, 5 and 6$)$ supplied sufficient manure $\mathrm{N}$ to meet the demand for $\mathrm{N}$ in the urban area (and up to $50 \%$ in the periurban area), but at the cost of a large oversupply of $\mathrm{P}$ and $\mathrm{K}$ in the urban area (up to $220 \%$ ). 
Table 4.5 Number of crop farms and estimated total N, P and K demands of crops grown in urban (zone A), peri-urban (zone B) and rural areas (zone C) of Addis Ababa and Jimma

\begin{tabular}{|c|c|c|c|c|c|c|c|c|}
\hline \multirow{3}{*}{ Area (Zone) } & \multicolumn{4}{|c|}{ Addis Ababa } & \multicolumn{4}{|c|}{ Jimma } \\
\hline & \multirow{2}{*}{$\begin{array}{l}\text { Number } \\
\text { of farms }\end{array}$} & \multicolumn{3}{|c|}{ Total demand, Gg year-1 } & \multirow{2}{*}{$\begin{array}{l}\text { Number } \\
\text { of farms }\end{array}$} & \multicolumn{3}{|c|}{ Total demand, Gg year-1 } \\
\hline & & $\mathrm{N}$ & $\mathrm{P}$ & $\mathrm{K}$ & & $\mathrm{N}$ & $\mathrm{P}$ & $\mathrm{K}$ \\
\hline Urban (A) & 1,097 & 0.11 & 0.02 & 0.10 & 1417 & 0.11 & 0.02 & 0.09 \\
\hline Peri-urban (B) & 14,435 & 3.63 & 0.52 & 3.11 & 1770 & 0.27 & 0.04 & 0.23 \\
\hline Rural (C) & 12,199 & 3.15 & 0.45 & 2.70 & 1018 & 0.18 & 0.03 & 0.15 \\
\hline Total & 27,731 & 6.89 & 0.99 & 5.91 & 4,205 & 0.56 & 0.08 & 0.48 \\
\hline
\end{tabular}

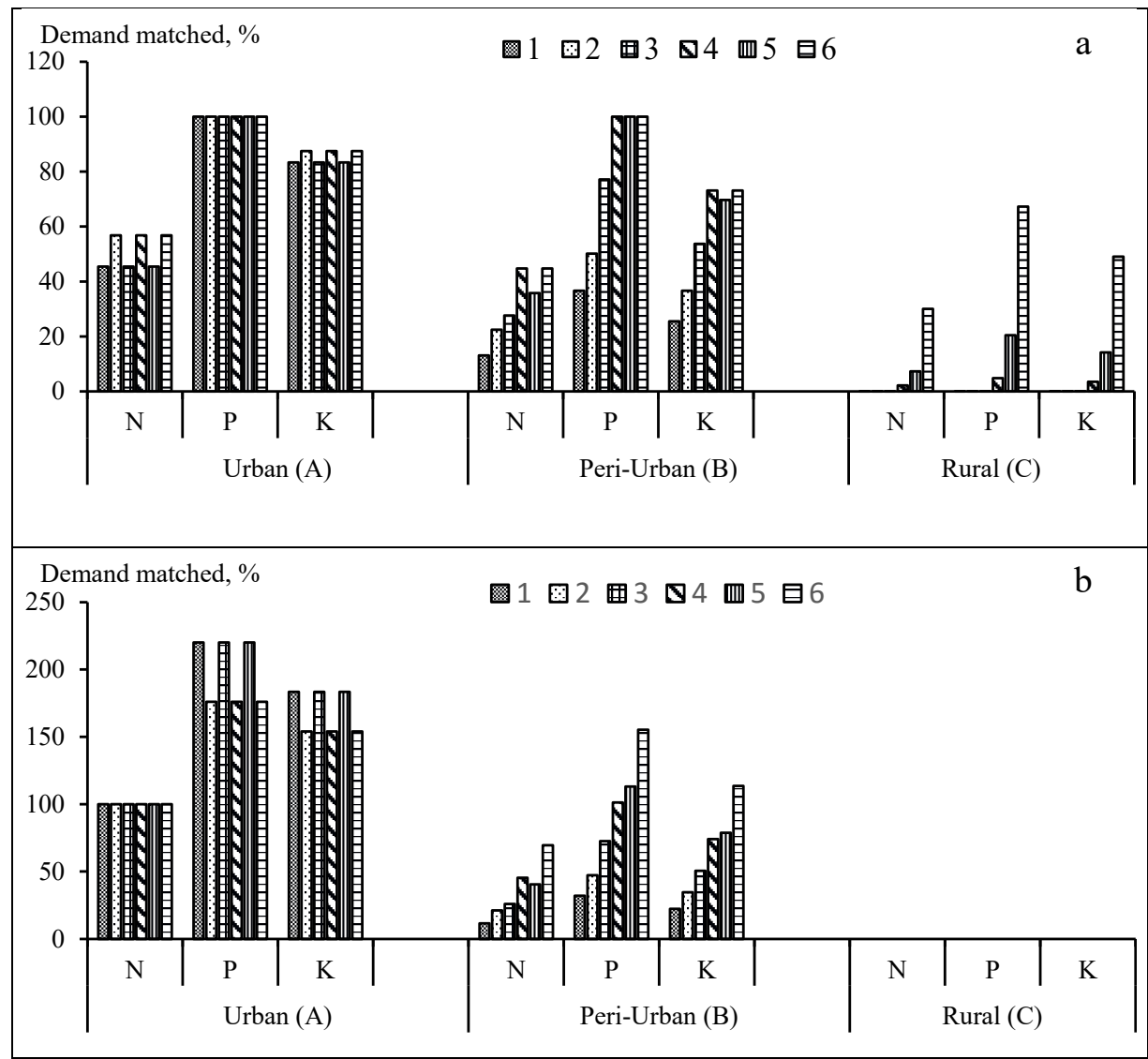

Figure 4.2 Supply of N, P and K from urban livestock manure relative to demand of N, P and $\mathrm{K}$ by crops in urban farms (zone A), peri-urban farms (zone B) and rural farms (zone C), as function of 6 variants (combinations of excretion coefficients and recovery fraction; see Table 4) in Addis Ababa. Upper graph (a): demand for phosphorus determines manure application rates (balanced $\mathrm{P}$ fertilization), first in urban areas, then peri-urban and finally rural areas. Lower graph (b): demand for nitrogen determines manure application rates (balanced $\mathrm{N}$ fertilization). 


\subsubsection{Recycling benefits}

Through the envisaged recycling, the total amounts of $\mathrm{N}, \mathrm{P}$ and $\mathrm{K}$ recovered in manure from urban livestock farms in Addis Ababa is equivalent to 1 to $4 \mathrm{Gg}$ di-ammonium phosphate (DAP), 0.7-3.9 Gg urea, and 2.3-9.6 Gg potassium chloride $(\mathrm{KCl})$ fertilizers. Similarly, the recycling of manure from urban livestock farms in Jimma may save 0.1-0.3 Gg DAP, 0.1-0.4 $\mathrm{Gg}$ urea and $0.2-0.8 \mathrm{Gg} \mathrm{KCl}$ fertilizers per year. These amounts are equivalent to savings of 75-300 and 6-24 million Ethiopian Birr (ETB), respectively (Table 4.6).

Table 4.6 Amounts of N, P and $\mathrm{K}$ recycled, and cost of synthetic fertilizers saved through recycling of manure from urban livestock farms to crop farms in urban, peri-urban and rural areas of Addis Ababa and Jimma. Ranges reflect the uncertainties in the amounts of manure recycled (Table 4.4).

\begin{tabular}{llllllll}
\hline City & \multicolumn{2}{l}{$\begin{array}{l}\text { Manure nutrients recycled, } \\
\mathrm{Gg} \mathrm{yr}^{-1}\end{array}$} & & \multicolumn{2}{l}{$\begin{array}{l}\text { Fertilizer equivalents } \\
\text { saved, } \mathrm{Gg} \mathrm{yr}^{-1}\end{array}$} & \multicolumn{2}{l}{$\begin{array}{l}\text { Savings, } \\
\text { million }\end{array}$} \\
\cline { 2 - 7 } & $\mathrm{N}$ & $\mathrm{P}$ & $\mathrm{K}$ & Urea & $\mathrm{DAP}$ & $\mathrm{KCl}$ & ETB yr $^{-1}$ \\
\hline Addis Ababa & $0.5-2.6$ & $0.2-0.8$ & $0.9-3.7$ & $0.7-3.9$ & $1-4$ & $2.3-9.6$ & $75-300$ \\
Jimma & $0.04-0.22$ & $0.02-0.07$ & $0.07-0.30$ & $0.1-0.3$ & $0.1-0.4$ & $0.2-0.8$ & $6-24$ \\
\hline
\end{tabular}

Note: 1000 Ethiopian Birr (ETB) $=30$ US\$

In addition, some 5 to $50 \mathrm{Gg}$ organic carbon in Addis Ababa and 0.6 to $6 \mathrm{Gg}$ organic $\mathrm{C}$ in Jimma will be returned with the manure to soil, which is equivalent to roughly 1 to $2 \mathrm{Mg} \mathrm{ha}^{-1}$ (assuming $\mathrm{C} / \mathrm{N}$ ratios that range from 10 to 20; Snijders et al. (2009). Further, an unknown amount of basic cations and secondary nutrients $(\mathrm{Ca}, \mathrm{Mg}, \mathrm{S})$ and micro nutrients (e.g. $\mathrm{Zn}, \mathrm{Cu}$ ) will be returned with the manure to cropland, which are essential for growth and development of crops, animals and humans (Berkhout et al., 2017). There are additional environmental benefits, because much less manure nutrients (e.g., 0.5 to $2.6 \mathrm{Gg} \mathrm{N}$ and 0.2 to $0.8 \mathrm{Gg} \mathrm{P}$ in Addis Ababa) from urban livestock farms pollute the urban environments.

\subsection{Discussion}

\subsubsection{Urban agriculture and nutrient balances}

Urban livestock farms are important for providing nutritious food, jobs and income, but the environmental costs of manure nutrient accumulation and soil and water pollution, and the risks of pathogen transfer and zoonosis are relatively high (Herrero et al., 2018; Khumalo and Sibanda, 2019; Steinfield et al., 2010). Both, its importance and the concerns are increasing, because urbanization is increasing, and associated with changes toward more animal-sourced diets. Traditionally, animals are and have been kept for different reasons and animals often have multiple functions. As a consequence, there is a huge diversity in urban livestock farming, which roughly falls in three main categories, i.e. (i) back yard/subsistence/small mixed farms, (ii) intensive/industrial/large animal feeding operations, and (iii) company /leisure/care pets and horses (Robinson et al., 2011a). Urban livestock farms in Ethiopia mainly fall in the first category, but the livestock sector is rapidly changing and in transition. 
There were about 5200 livestock farms with on average 0.6 ha of land and 13.5 TLU per farm in the urban zone of Addis Ababa. These farms produced 560-1690 kg N, 113-338 kg P and $560-1690 \mathrm{~kg} \mathrm{~K} \mathrm{ha}^{-1} \mathrm{yr}^{-1}$ in manure, which is much more than can be taken up by most crops, as follows also from the relatively large $\mathrm{N}, \mathrm{P}$ and $\mathrm{K}$ surpluses of urban livestock farms (Table 4.3). Even when the recovery fractions of $30-50 \%$ for $\mathrm{N}, 60-80 \%$ for $\mathrm{P}$ and $50-70 \%$ for $\mathrm{K}$ were taken into account, amounts of manure nutrients available for the limited area of crop land on the farm remain much higher than what can be taken up by most crops.

Though the urban livestock farms were much wealthier than other farms in the urban, periurban and rural areas (Table 4.2), these farms were still small compared to many urban and peri-urban livestock farms in emerging markets economies such as China (Steinfield et al., 2010; Wei et al., 2015). These factory farms or confined animal feeding operations often have thousands of pigs or hundreds of dairy cows, and also have little or no land for manure disposal, and thereby create serious air, water and soil pollution (Bai et al., 2018a). However, our data suggest that 5200 small livestock farms together may create rather similar manure nutrient surpluses in Addis Ababa as the few hundred large pig farms around Beijing do (Wei et al., 2015). The difference is that the small livestock farms in Addis Ababa are diffusively spread and perhaps less visible.

There were nearly 5 times less crop farms (1100) than livestock farms in the urban zone (Table 4.5). These crop farms had on average 1.7 ha of land and 4 TLU per farm (Table 4.2), and had negative $\mathrm{N}$ and $\mathrm{K}$ balances and slightly positive P balances (Table 4.3), despite 2 TLU ha- ${ }^{-1}$. Likely, most feed was produced on-farm and little imported, because mixed farms with relatively large area of crop land invest relatively little in animal production (Tadesse et al., 2019); the N, P and K excretion coefficients applicable for the livestock in these mixed crop farms were likely at the lower end of the range used in our calculations (Table 4.4). The negative $\mathrm{N}$ and $\mathrm{K}$ balances indicate that there was little exchange of manure between livestock farms and crop farms in the urban zone; crop farms with nutrient depletion co-existed next to livestock farms with large manure nutrient surpluses. Though crop farmers know the value of manure for crop production, there is need for education and extension services that encourage exchange and interaction between farmers for increasing adoption of good manure management practices (Ndambi et al., 2019). Lack of knowledge and clear guidelines were also identified as main reasons for poor nutrient management practices of urban gardeners in The Netherlands (Wielemaker et al., 2019).

\subsubsection{Manure recycling between urban livestock farms and crop farms}

Manure is a heterogeneous product and the composition is not known in practice, generally. The heterogeneity of cattle manure is related to variations in the composition of the diet, in nutrient retention in animal production, and in losses during storage. Snijders et al. (2009) reviewed literature on the composition of cattle manure in east Africa, and based on their review we derived at the following composition (mean \pm standard deviation; $\mathrm{n}>20$ ): $1.7 \pm 0.7 \%$ $\mathrm{N} ; 0.5 \pm 0.3 \% \mathrm{P}$ and $1.8 \pm 1.3 \% \mathrm{~K}$, with a $\mathrm{N} / \mathrm{P}$ ratio of $4.1 \pm 1.7$ and a $\mathrm{K} / \mathrm{P}$ ratio of $4.6 \pm 2.7$ 
(medians were 3.8 and 3.6, respectively). The ratios of the manure in our estimates $(\mathrm{N} / \mathrm{P}=2.5$ 3.1 and $\mathrm{K} / \mathrm{P}=4.2-4.4$; derived from Table 4.4) fall in the lower half of the indicated ranges, suggesting that our manures were relatively $\mathrm{N}$ and $\mathrm{K}$ poor and/or P rich (Rufino et al., 2014).

In total 0.5-2.6 Gg N, 0.2-0.8 Gg P and 0.9-3.7 Gg K can be recovered in manure from urban livestock farms in Addis Ababa (Table 4.4), and utilized in crop farms in urban and peri-urban zones, following the 'balanced $\mathrm{P}$ fertilization' or 'balanced $\mathrm{N}$ fertilization' strategies (Figure 4.2). Balanced $P$ fertilization assumes that the crop $P$ demand is met through manure, and that synthetic $\mathrm{N}$ and $\mathrm{K}$ fertilizers (or other nutrient sources) should be used to top up, to match the remaining $\mathrm{N}$ and $\mathrm{K}$ demands. Balanced $\mathrm{N}$ fertilization assumes that the crop $\mathrm{N}$ demand is met through manure and that $\mathrm{P}$ and $\mathrm{K}$ demands are also met. Balanced $\mathrm{N}$ fertilization led to a relative oversupply of $\mathrm{P}$ and $\mathrm{K}$ (Figure 4.2), and to less manure transport and distribution than balanced $\mathrm{P}$ fertilization. Balanced $\mathrm{P}$ fertilization is a better strategy from nutrient management perspective, as it allows for greater precision through matching supply and demand for all three nutrients.

We made no corrections for the fertilizer $\mathrm{N}$ effectiveness value of the manure (defined as the fraction of manure $\mathrm{N}$ that has similar effect as common synthetic $\mathrm{N}$ fertilizer). This value may range from 0.3 to 1.0 depending on the composition and application rate of the manure, and the duration of manure use and accounting for period (Schröder et al., 2007; Zhang et al., 2020b). Correcting for the fertilizer $\mathrm{N}$ effectiveness value of the manure would thus have increased the manure application rate in the balanced $\mathrm{N}$ fertilization strategy, and would have led to larger $\mathrm{P}$ and $\mathrm{K}$ over fertilization. The $\mathrm{P}$ and $\mathrm{K}$ effectiveness values of manure are generally set at 1 (equal to high-grade synthetic P and K fertilizers; Oenema et al. (2012)).

We made no corrections for manure application on crop land of livestock farms, and for manure production by livestock on crop farms. In the urban area the demand for P by the crop in livestock farms was similar to the supply of $\mathrm{P}$ in manure from the livestock in crop farms, and thus cancel each other more or less out. However, by neglecting the nutrient demand by the crop of livestock farms, and the nutrient supply in the manure produced in crop farms, we overestimated the need for manure transport and redistribution. Hence, such corrections should be made in future studies.

The estimated amounts of manure that may be recovered on urban livestock farms in Addis Ababa are rather similar to the amounts that may be recovered from urban livestock farms in other large cities in East Africa. De Zeeuw et al. (2011) reported that 2.2 Gg N, 2.2 Gg P and 3.7 Gg K could be recovered from manure and waste in Nairobi. Komakech (2014) reported rather similar numbers for urban cattle manure in Kampala, and estimated also significant synthetic fertilizer savings. Though significant, the amounts of $\mathrm{N}$ and $\mathrm{P}$ produced in cattle manure in urban farms are about one order of magnitude lower than the total $\mathrm{N}$ and $\mathrm{P}$ excretion by the human population in Addis Ababa. When assuming a mean protein $\mathrm{N}$ intake of $3 \mathrm{~kg}$ and a $\mathrm{P}$ intake of $0.6 \mathrm{~kg}_{\text {capita }}{ }^{-1}$, the annual total $\mathrm{N}$ and $\mathrm{P}$ in human waste production will be about $10 \mathrm{Gg} \mathrm{N}$ and $2 \mathrm{Gg}$ P. However, the recovery and recycling of N, P and $\mathrm{K}$ from human wastes 
are complicated, although there is an increasing need to do so (Guerrero et al., 2013; Hodson et al., 2012).

\subsubsection{Recycling benefits and barriers}

Urban manure recovery and recycling may have energy, economic and environmental benefits, the 3Es aspects (Rodionov and Nakata (2011). Estimated fertilizer saving for Addis Ababa were in the range of 75 to 300 Ethiopian Birr (Table 4.6). Additional benefits relate to replenishing nutrients in crop land and to improving soil quality and nutrient balances (McConville et al., 2017; Szogi et al., 2015). More difficult to-account-for benefits include reductions in the pollution of soil, surface waters and groundwater, and in the threat of food safety, human health and biodiversity loss (Wen et al., 2017).

Though beneficial, manure recycling is not practiced in the study urban regions at present as shown by Tadesse et al. (2018) who reported that landless cLS (commercial livestock) farms with surplus LSM (livestock manure), simply dumped large quantity of LSM into ditches and farm surroundings or left it unmanaged on the ground. Similarly, in Kampala city, many livestock farms discard and dumped LSM into drainage channels, where it is carried off by running water, because there is no comprehensive national urban policy and institutional framework to regulate the use of solid waste (Komakech, 2014). In addition to losses of nutrient resources, unmanaged wastes may contribute to pollution of the urban environment (Wen et al., 2017). Where waste is managed, Nigussie et al. (2015) reported that large quantity of waste was dumped in landfills in these urban areas. Landfilling of organic wastes contribute to pollution issues related to landfill leachate and gas as well as the loss of valuable nutrients and organic matter. There are many factors leading to these outcomes as Marshall and Farahbakhsh (2013) citing cultural, socioeconomic, governance and institutional aspects limiting solid waste management in many developing countries. There are currently no incentives or policies to encourage the recycling of LSM from urban farms to crop farms in the study urban regions. Guerrero et al. (2013) and Komakech (2014) reported the absence of satisfactory policies or mere presence of weak policies and regulations as the critical causes for the failed solid waste management systems in low-income countries. Shortage of land and lack of tenure rights in urban LS farms (Table 4.2) for manure use or disposal, lack of appropriate institutions and poor infrastructures in the study urban regions are also barriers for LSM recycling. Guerrero et al. (2013) stated as success of recycling depends on the efficiency of infrastructures. Improving animal housing and LSM storage conditions, may reduce nutrient losses and increase the nutrient recovery and thus can maximize the potential of recycling LSM nutrients.

Further, the possible presence of pathogens, pharmaceutical compounds and veterinary products such as hormones and antibiotics in manure are sometimes seen as additional barriers for recycling (Hou et al., 2017; Manyi-Loh et al., 2016; Martens and Bohm, 2009). These barriers could be addressed through anaerobic digestion and/or composting (Cliver, 2009; Manyi-Loh et al., 2016). Evidently, recycling manure from urban to peri-urban and rural areas requires awareness raising, guidelines and protocols, and appropriate institutions, incentives 
and advisory services (Mulugeta, 2013). In the end, it requires also careful monitoring and control. Thus, policymakers and stakeholders should promote manure reuse through incentives, technologies and appropriate strategies and policies, to improve nutrient use and reduce the pollution of the environment (Herrero et al., 2018).

\subsubsection{Limitations and uncertainties of our study}

Coupling livestock production to crop production via direct exchanges of animal feed and animal manure is key for increasing the sustainability of food production systems. In our study, we focused on the recycling of manure from urban livestock farms to crop farms only. Though livestock farms and crop farms were visited twice, there is as yet little accurate quantitative information about animal feed origin and rations and animal productivity. Hence, we have no accurate information about $\mathrm{N}, \mathrm{P}$ and $\mathrm{K}$ excretion rates and $\mathrm{N}, \mathrm{P}$ and $\mathrm{K}$ contents of recovered manures. We addressed this uncertainty through using ranges (Table 4.4). Uncertainties arise also from the uncertainties in crop areas and number of farms and animals. Further, the N, P and $\mathrm{K}$ demand of crops were derived from MonQIt, which is a static model and does not account for seasonal variations in N, P and $\mathrm{K}$ demand and supply, (e.g., Krause and Rotter (2018)).

The livestock sector responds to changes in markets and the availability of new technology, which are influenced subsequently by urbanization and globalization. Though livestock farms in the urban zones of Addis Ababa and Jimma are still relatively small compared to farms in for example east Asia, it cannot be excluded that rapid changes may occur. This calls for more dynamic approaches including considerations of long-term effects of manure and fertilizer applications on soil fertility level and the response of crops to these changes (Zoboli et al., 2016). Further insights may be accomplished through scenario analyses and measurements of feed, manures and soil.

\subsection{Conclusions}

The $>5000$ livestock farms in the urban zones of Addis Ababa and the 500 livestock farms in Jimma produce more $\mathrm{N}, \mathrm{P}$ and $\mathrm{K}$ in manure than the $>1000$ crop farms in the urban zones of these cities demand for. Yet, crop farms in the urban area have negative $\mathrm{N}$ and $\mathrm{K}$ balances (but positive $\mathrm{P}$ balances because of subsidized fertilizers) and use little or no manure from livestock farms. We estimated how much $\mathrm{N}, \mathrm{P}$ and $\mathrm{K}$ in manure may be recovered in urban livestock farms, and how much may be used in urban, peri-urban and rural crop farms.

A balanced $\mathrm{P}$ fertilization strategy was preferred to a balanced $\mathrm{N}$ fertilization strategy for estimating the allocation of manure in crop farms. The former will require a top-up with $\mathrm{N}$ and $\mathrm{K}$ from other nutrient sources, while the latter will lead to over fertilization with $\mathrm{P}$ and $\mathrm{K}$, especially on the long term. 
Recycling manure from urban livestock farms to crop farms has several benefits, including fertilizer savings, nutrient replenishment in crop land, restoring nutrient balances, and minimizing soil, air and water pollution. However, lack of knowledge, advisory services, and policy incentives, and cultural and institutional barriers appear to prevent cashing in these benefits. There is also a significant uncertainty in the estimated benefits, due to lack of accurate data. Our study may help policy makers to prioritize and define research and policies related to re-connecting animal production and crop production systems through manure recycling in the urban environment. Further studies should focus on collecting quantitative data related to improving the performances of animal and crop production systems in the urban area, and should explore more sustainable development pathways. 


\section{Chapter 4}

\section{References:}

Abdalla S.B., Predotova M., Gebauer J., Buerkert A. (2011) Horizontal nutrient flows and balances in irrigated urban gardens of Khartoum, Sudan. Nutr Cycl Agroecosyst 92: 119-132.

Abebe M.S., Derebew K.T., Gemeda D.O. (2019) Exploiting temporal-spatial patterns of informal settlements using GIS and remote sensing technique: a case study of Jimma city, Southwestern Ethiopia. Environmental Systems Research 8.

Abrha C., Feyisa G.L., Feyssa D.H. (2015) Analysis of land use/cover dynamics in Jimma city, Southwest Ethiopia: an application of satellite remote sensing. EJAST 6: 24-34.

Admasu T.G., Runnstrom M. (2017) Monitoring trends of greenness and LULC (land use/land cover) change in Addis Ababa and its surrounding using MODIS time-series and LANDSAT Data. MSc Thesis, Department of Physical Geography and Ecosystem Science Lund University: pp 60.

Allen A. (2003) Environmental planning and management of peri-urban interface: perspectives on an emerging field. Environment and Urbanization 15: 135-147.

Alvarez S., Rufino M.C., Vayssières J., Salgado P., Tittonell P., Tillard E., Bocquier F. (2014) Whole-farm nitrogen cycling and intensification of crop-livestock systems in the highlands of Madagascar: An application of network analysis. Agricultural Systems 126: $25-37$.

Bai Z., Ma W., Ma L., Velthof G.L., Wei Z., Havlík P., Oenema O., Lee M.R.F., Zhang F. (2018) China's livestock transition: Driving forces, impacts, and consequences. Science Advances 4(7): 1-11.

Bekunda M., Manzi G. (2003) Use of the partial nutrient budget as an indicator of nutrient depletion in the highlands of southwestern Uganda. Nutr Cycl Agroecosyst 67: 187195.

Berkhout E., Malan M., Kram T. (2017) Micronutrients for agricultural intensification - Is SubSaharan Africa at risk? PBL publication 1946. Netherlands Environmental Assessment Agency, The Hague.

Bicudo J.R. (2009) Animal Solid Manure: Storage, Handling and Disposal. In: Mcnulty, P and Parick MG (Eds.) Agricultural Mechanization And Automation, Oxford, United Kingdom: Encyclopedia of life support systems (EOLSS) publisher co.ltd, p. 263-291.

Buckwell A., Nadeu E. (2016) Nutrient Recovery and Reuse (NRR) in European agriculture. A review of the issues, opportunities, and actions. RISE Foundation, Brussels.

Chihambakwe M., Mafongoya P., Jiri O. (2018) Urban and Peri-Urban Agriculture as A Pathway to Food Security: A Review Mapping the Use of Food Sovereignty. Challenges 10 .

Cliver D.O. (2009) Disinfection of animal manures, food safety and policy. Bioresour Technol 100: $5392-5394$. 
De Zeeuw H, van Veenhuizen R, Dubbeling M (2011) The role of urban agriculture in building resilient cities in developing countries. The Journal of Agricultural Science 149: 153163

Djurfeldt A.A. (2015) Urbanization and linkages to smallholder farming in sub-Saharan Africa: Implications for food security. Global Food Security 4: 1-7.

Eyasu E., van Beek C.L. (2015) Scaling Innovations and Agricultural Best Practices in Ethiopia: Experiences and Challenges..Proceedings of the CASCAPE National Stakeholder Conference, 23-24 April 2014. Addis Ababa. Ethiopia. CASCAPE Project, Wageningen University and Research Centre (WUR), Wageningen, The Netherlands.

FAO (2017) The future of food and agriculture-Trends and challenges. Rome

Feyisa G.L., Meilby H., Darrel Jenerette G., Pauliet S. (2016) Locally optimized separability enhancement indices for urban land cover mapping: Exploring thermal environmental consequences of rapid urbanization in Addis Ababa, Ethiopia. Remote Sensing of Environment 175: 14-31.

Goulding K., Jarvis S., Whitmore A. (2008) Optimizing nutrient management for farm systems. Philos Trans R Soc Lond B Biol Sci 363: 667-680.

Guerrero L.A., Maas G., Hogland W. (2013) Solid waste management challenges for cities in developing countries. Waste management 33: 220-232.

Herrero M.A. et al (2018) Dairy manure management perceptions and needs in South American countries. Frontiers in sustainable food systems 2.

Hodson M., Marvin S., Robinson B., Swilling M. (2012) Reshaping Urban Infrastructure. Journal of Industrial Ecology, 16: 789-800.

Hou Y., Velthof G.L., Lesschen J.P., Staritsky I.G., Oenema O. (2017) Nutrient Recovery and Emissions of Ammonia, Nitrous Oxide, and Methane from Animal Manure in Europe: Effects of Manure Treatment Technologies. Environmental science and technology 51: 375-383.

Jones D.L., Cross P., Withers P.J.A., Deluca T.H., Robinson D.A., Quilliam R.S., Harris I.M., Chadwick D.R., Edwards-Jones G., Kardol P. (2013) REVIEW: Nutrient stripping: the global disparity between food security and soil nutrient stocks. Journal of Applied Ecology 50: 851-862.

Khumalo N., Sibanda M. (2019) Does Urban and Peri-Urban Agriculture Contribute to Household Food Security? An Assessment of the Food Security Status of Households in Tongaat, eThekwini Municipality. Sustainability 11.

Komakech A.J. (2014) Urban waste management and the environmental impact of organic waste treatment systems in Kampala, Uganda PhD, Swedish University of Agricultural Sciences, Uppsala and Makerere University, Kampala.

Krause A., Rotter V. (2018) Recycling Improves Soil Fertility Management in Smallholdings in Tanzania. Agriculture 8.

Lin T., Gibson V., Cui S., Yu C.P., Chen S., Ye Z., Zhu Y.G. (2014) Managing urban nutrient biogeochemistry for sustainable urbanization. Environ Pollut 192: 244-250.

Liu Q., Wang J., Bai Z., Ma L., Oenema O. (2017) Global animal production and nitrogen and phosphorus flows. Soil Research 55: 451.

Lupindu A.M. (2017) Public Health Aspect of Manure Management in Urban and Peri-Urban Livestock Farming in Developing Countries. Livestock Science. 
Makita K., Fevre E.M., Waiswa C., Bronsvoort M.D., Eisler M.C., Welburn S.C. (2010) Population-dynamics focussed rapid rural mapping and characterisation of the periurban interface of Kampala, Uganda. Land use policy 27: 888-897.

Manyi-Loh C.E., Mamphweli S.N., Meyer E.L., Makaka G., Simon M., Okoh A.I. (2016) An Overview of the Control of Bacterial Pathogens in Cattle Manure. Int J Environ Res Public Health 13.

Marshall R.E., Farahbakhsh K. (2013) Systems approaches to integrated solid waste management in developing countries. Waste management 33: 988-1003.

Martens W., Bohm R. (2009) Overview of the ability of different treatment methods for liquid and solid manure to inactivate pathogens. Bioresour Technol 100: 5374-5378.

McConville J., Drangert J.-O., Tidaker P., Neset T.-S., Rauch S., Strid I., Tonderski K. (2017) Closing the food loops: guidelines and criteria for improving nutrient management. Sustainability: Science, Practice, and Policy 11: 33-43.

Michelini G., Moraes R.N., Cunha R.N., Costa J.M.H., Ometto A.R. (2017) From Linear to Circular Economy: PSS Conducting the Transition. Procedia CIRP 64: 2-6.

Mohamed A., Worku H. (2019) Quantification of the land use/land cover dynamics and the degree of urban growth goodness for sustainable urban land use planning in Addis Ababa and the surrounding Oromia special zone. Journal of Urban Management $8(1): 145-158$.

Mugisa I.O. et al (2017) Urban and peri-urban crop farming in Central Uganda: Characteristics, constraints and opportunities for household food security and income. African Journal of Plant Science 11: 264-275.

Mukai S. (2018) Historical role of manure application and its influence on soil nutrients and maize productivity in the semi-arid Ethiopian Rift Valley. Nutr Cycl Agroecosyst.

Mulugeta M. (2013) The Need for Policy Framework for Urban/Peri-Urban Agriculture in Ethiopia: A Reflection. EJOSSAH 9: 79-109.

Ndambi O.A., Pelster D.E., Owino J.O., de Buisonjé F., Vellinga T. (2019) Manure Management Practices and Policies in Sub-Saharan Africa: Implications on Manure Quality as a Fertilizer. Front. Sustain. Food Syst. 3: 29.

Negash D., Abegaz A., Smith J.U., Araya H., Gelana B. (2017) Household energy and recycling of nutrients and carbon to the soil in integrated crop-livestock farming systems: a case study in Kumbursa village, Central Highlands of Ethiopia. GCB Bioenergy 9: 1588-1601.

Neo H. (2010) The potential of large-scale urban waste recycling: A case study of the national recycling programme in Singapore. Society \& Natural Resources 23: 872-887.

Nigussie A., kuyper T.W., de Neergaard A. (2015) Agricultural waste utilisation strategies and demand for urban waste compost: Evidence from smallholder farmers in Ethiopia. Waste Manag 44: 82-93.

Oenema O., Chardon W.J., Ehlert P.A.I., van Dijk K.C., Schoumans O.F., Rulkens W.H. (2012) Phosphorus fertilisers from by-products and wastes. Proceeding 717. International Fertiliser Society, Leek, p. 1-55. Research output: Contribution to conference $>$ Conference paper $>$ Academic. 
Opitz I., Berges R., Piorr A., Krikser T. (2015) Contributing to food security in urban areas: differences between urban agriculture and peri-urban agriculture in the Global North. Agriculture and Human Values 33: 341-358.

Pergola M., Persiani A., Palese A.M., Di Meo V., Pastore V., D’adamo C., Celano G. (2017) Composting: The way for a sustainable agriculture. Applied Soil Ecology.

Rao K., Otoo M., Drechsel P., Hanjra M. (2017) Resource Recovery and Reuse as an Incentive for a More Viable Sanitation Service Chain. Water Alternatives 10: 493-512.

Robinson T.P., Thornton P.K., Franceschini G., Kruska R.L., Chiozza F., Notenbaert A., Cecchi G., Herrero M., Epprecht M., Fritz S., You L., Conchedda G., See.L. (2011). Global livestock production systems. Food and Agriculture Organization of the United Nations (FAO) and International Livestock Research Institute (ILRI), 152 pp.

Rodionov M., Nakata T. (2011) Design of an Optimal Waste Utilization System: A Case Study in St. Petersburg, Russia. Sustainability 3: 1486-1509.

Roessler R., Mpouam S., Muchemwa T., Schlecht E. (2016) Emerging development pathways of urban livestock production in rapidly growing West Africa cities. Sustainability 8.

Rufino M.C., Brandt P., Herrero M., Butterbach-Bahl K. (2014) Reducing uncertainty in nitrogen budgets for African livestock systems. Environmental Research Letters 9.

Rufino M.C., Tittonell P., van Wijk M.T., Castellanos-Navarrete A., Delve R.J., de Ridder N., Giller K.E. (2007) Manure as a key resource within smallholder farming systems: Analyzing farm-scale nutrient cycling efficiencies with the NUANCES framework. Livestock Science 112: 273-287.

Satterthwaite D. (2017) The impact of urban development on risk in sub-Saharan Africa's cities with a focus on small and intermediate urban centres. International Journal of Disaster Risk Reduction 26: 16-23.

Schröder J.J., Uenk D., Hilhorst G.J. (2007) Long-term nitrogen fertilizer replacement value of cattle manures applied to cut grassland. Plant and Soil 299: 83-99.

Sheldrick, Syers J.K., Lingard J. (2003) Contribution of livestock excreta to nutrient balances. Nutr Cycl Agroecosyst 66: 119-131.

Simon D. (2008) Urban Environments: Issues on the Peri-Urban Fringe. Annu Rev Environ Resour 33: 167-185.

Smaling E.M.A., Lesschen J.P., van Beek C.L., De Jager A., Stoorvogel J.J., Batjes N.H., Fresco L.O. (2013) Where do we stand 20 years after the assessment of soil nutrient balances in sub-Saharan Africa? In: Lal R, Steart BA (eds) World soil resources and food security. CRC press, Taylor \& Francis Group, Boca Raton.

Smits M.-J., Woltjer G. (2018) Phosphorus Recycling from Manure: A Case Study on the Circular Economy. Deliverable 4: 61.

Snijders P., Onduru D., Wouters B., Gachimbi L., Zake J., Ebanyat P., Ergano K., Abduke M., van Keulen M. (2009) Cattle manure management in East Africa: Review of manure quality and nutrient losses and scenarios for cattle and manure management. Report 258, Wageningen Livestock Research. ISSN 1570-8616.

Steinfeld H., Mooney H.A., Schneider F., Neville L.E. (Eds) (2010) Livestock in a Changing Landscape-Drivers, Consequences, and Responses. Island Press, London. 396 pp.

Sutton A.L. (1994) Proper animal manure utilization 39, pp. Journal of Soil and Water Conservation 39: 65-70. 
Szogi A.A., Vanotti M.B., Ro K.S. (2015) Methods for treatment of animal manures to reduce nutrient pollution prior to soil application. Current Pollution Reports 1: 47-56.

Tabor K.W. (2013) Land use and land cover dynamic, socio-economic and environmental transformations and implications: A geographical study of the fringe of Finfinnee (Addis Ababa) city, Ethiopia. PhD Thesis at Department of geography, Osmania University Hyderabad - 500007, India: 422.

Tadesse S.T., Oenema O., van Beek C.L., Ocho F.L. (2018) Diversity and nutrient balances of urban and peri-urban farms in Ethiopia. Nutr Cycl Agroecosyst 111: 1-18.

Tadesse S.T., Oenema O., van Beek C., Ocho .FL. (2019) Nitrogen allocation and recycling in peri-urban mixed crop-livestock farms in Ethiopia. Nutr Cycl Agroecosyst 115(2):145158.

Tamiru M., Amza N. (2017) Review on the status of dairy cattle production in Ethiopia. Journal of Genetic and Environmental Resources Conservation 5: 84-95.

Tefera T.L., Azage T., Hoekstra D. (2012) Capacity for knowledge based smallholder agriculture in Ethiopia: Linking graduate programs to market-oriented agricultural development: Challenges, opportunities and IPMS experience. IPMS (Improving Productivity and Market Success) of Ethiopian Farmers Project Working Paper 29. Nairobi, Kenya, ILRI. www.ilri.org.

Terfa B.K., Chen N., Liu D., Zhang X., Niyogi D. (2019) Urban Expansion in Ethiopia from 1987 to 2017: Characteristics, Spatial Patterns, and Driving Forces. Sustainability 11

Thebo AL, Drechsel P, Lambin E F (2014) Global assessment of urban and peri-urban agriculture: irrigated and rainfed croplands. Environmental Research Letters 9.

UN-DESA (2019) World Urbanization Prospects: The 2018 Revision. 420. United Nations.

van Beek C.L., Elias E., Yihenew G.S., Heesmans H., Tsegaye A., Feyisa H., Tolla M., Mamuye M., Gebremeskel Y., Mengist S. (2016) Soil nutrient balances under diverse agro-ecological settings in Ethiopia. Nutr Cycl Agroecosyst 106: 257-274.

van Beek C.L., Meerburg BG, Schils RLM, Verhagen J, Kuikman PJ (2010) Feeding the world's increasing population while limiting climate change impacts: linking $\mathrm{N}_{2} \mathrm{O}$ and $\mathrm{CH}_{4}$ emissions from agriculture to population growth. Environ Science and Policy 13: 89-96.

Vlaming J., van Beek C.L., Heinen M., van Duivenbooden N. (2012) MonQIt monitoring for quality improvement MonQIt basic user manual. www.monqi.org.

Wang F., Wang Z., Kou C., Ma Z., Zhao D. (2016) Responses of Wheat Yield, Macro- and Micro-Nutrients, and Heavy Metals in Soil and Wheat following the Application of Manure Compost on the North China Plain. PloS one 11: 1-18.

Wei S., Bai Z.H., Qin W., Xia L.J., Oenema O., Jiang R.F., Ma L. (2016) Environmental, economic and social analysis of peri-urban pig production, Journal of Cleaner Production. doi: 10.1016/j.jclepro.2016.03.133.

Wen Y., Schoups G., van De Giesen N. (2017) Organic pollution of rivers: Combined threats of urbanization, livestock farming and global climate change. Scientific reports 7 : 43289.

Wielemaker R., Oenema O., Zeeman G., Weijma J. (2019) Fertile cities: Nutrient management practices in urban agriculture. Science of the Total Environment 668: 1277-1288. 
Yu C., Xiao Y., Ni S. (2017) Changing patterns of urban-rural nutrient flows in China: driving forces and options. Science Bulletin 62: 83-91.

Yu J., Wu J. (2018) The Sustainability of Agricultural Development in China: The AgricultureEnvironment Nexus. Sustainability 10.

Zewdie M., Worku H., Bantider A. (2018) Temporal Dynamics of the Driving Factors of Urban Landscape Change of Addis Ababa During the Past Three Decades. Environ Manage 61: 132-146.

Zhang X., Fang Q., Zhang T., Ma W., Velthof G.L., Hou Y., Oenema O., Zhang F. (2020) Benefits and trade-offs of replacing synthetic fertilizers by animal manures in crop production in China: A meta-analysis. Global Change Biology 26: 888-900.

Zhu Y.G., Reid B.J., Meharg A.A., Banwart S.A., Fu B.J. ( 2017) Optimizing Peri-URban Ecosystems (PURE) to re-couple urban-rural symbiosis. Sci Total Environ 586: 10851090.

Zoboli O., Zessner M., Rechberger H. (2016) Supporting phosphorus management in Austria: Potential, priorities and limitations. Sci Total Environ 565: 313-323. 


\section{CHAPTER 5}

\section{Exploring the recycling of manure from urban livestock farms: a case study in Ethiopia}

This chapter is published as:

Solomon Tulu TADESSE, Oene OENEMA, Christy van BEEK, Fikre Lemessa OCHO (2021b) Exploring the recycling of manure from urban livestock farms: a case study in Ethiopia. Front. Agr. Sci. Eng. 8(1): 159-174. doi.org/10.15302/J-FASE-2020375. 


\begin{abstract}
Urban population growth is driving the expansion of urban and peri-urban agriculture (UPA) in developing countries. UPA is providing nutritious food to residents but the manures produced by UPA livestock farms and other wastes are not properly recycled. This paper explores the effects of four scenarios: (1) a reference scenario (business as usual), (2) increased urbanization, (3) UPA intensification, and (4) improved technology, on food-protein selfsufficiency, manure nitrogen $(\mathrm{N})$ recycling and balances for four different zones in a small city (Jimma) in Ethiopia during the period 2015-2050. An N mass flow model was used with data from farm surveys, field experiments and literature. A field experiment was conducted and $\mathrm{N}$ use efficiency and $\mathrm{N}$ fertilizer replacement values differed among the five types of composts derived from urban livestock manures and kitchen wastes. The $\mathrm{N}$ use efficiency and $\mathrm{N}$ fertilizer replacement values were used in the $\mathrm{N}$ mass flow model. Livestock manures were the main organic wastes in urban areas, although only 20 to $40 \%$ of animal-sourced food consumed was produced in UPA, and only 14 to $19 \%$ of protein intake by residents was animal-based. Scenarios indicate that manure production in UPA will increase 3 to 10 times between 2015 and 2050, depending on urbanization and UPA intensification. Only 13 to $38 \%$ of manure N will be recycled in croplands. Farm-gate $\mathrm{N}$ balances of UPA livestock farms will increase to $>$ $1 \mathrm{t} \mathrm{ha}^{-1}$ in 2050 . Doubling livestock productivity and feed protein conversion to animal-sourced food will roughly halve manure $\mathrm{N}$ production. Costs of waste recycling were high and indicate the need for government incentives. Results of these senarios are wake-up calls for all stakeholders and indicate alternative pathways.
\end{abstract}

Keywords: compost, food self-sufficiency, livestock production, nitrogen balance, nitrogen use efficiency, scenario analysis 


\section{$5.1 \quad$ Introduction}

The urban population of Africa has increased > 16 times between 1950 and 2018, from 33 to 548 million. During the same period the African component of the global urban population has increased from 4 to $13 \%$. In 2050, Africa will have $22 \%$ of the global urban population with about 1.5 billion urban dwellers (UN, 2019). This growing urban population is increasing urban food demand (Swain and Teufel, 2017) and is drawing food and nutrients from the proximate rural and peri-urban areas (Yu et al., 2017). Thereby, urbanization is aggravating soil nutrient depletion in rural areas, and this is a major constraint to agricultural production in many subSaharan African countries (Agegnehu and Amede, 2017; van Beek et al., 2016). Soil nutrient depletion is mainly due to nutrient removal through crop harvests and to limited nutrient replenishment via residues, manures and fertilizers (Teshome, 2014). Thus, the increase in average yield of major cereal crops has been stagnating in this region; for example, it is $\sim 2 \mathrm{t}$ $\mathrm{ha}^{-1}$ in Ethiopia, while the global average is $>3.5 \mathrm{tha}^{-1}$ (Agegnehu and Amede, 2017).

Ethiopia has a surface area of 1.1 million square kilometers $\left(\mathrm{km}^{2}\right)$ and had 109 million people in 2019 with a mean population density of $100 \mathrm{~km}^{-2}$. Most people work in agriculture $(>80 \%)$ and live in the highlands in the center of the country on $<$ half of the total area, where rainfall ranges from 1000 to $2000 \mathrm{~mm} \mathrm{yr}^{-1}$. Ethiopian agriculture has a relatively high potential but would be considered to be largely undeveloped; as a consequence, Ethiopia has a precarious food security situation, also because of climate variability (Di Falco et al., 2011; Tesfaye K et al., 2018).

In the process of urbanization, urban and peri-urban agriculture (UPA) is becoming more important in providing food mainly to urban people because increasing numbers of urban poor are engaged in diverse types of UPA systems as poverty alleviation strategies (Kwasi, 2010; Mulugeta, 2013). Urbanization and income growth are also deriving substantial increases in the demand for animal-sourced food and vegetables (Tadesse et al., 2018; Thornton, 2010). Livestock farms are important among UPA farms in Ethiopia; these farms largely depend on animal feed scavenged from neighborhoods and feed imported from rural areas, as they have little or no land (Tadesse et al., 2018). The manure of the livestock, which contains 60 to $95 \%$ of the nutrients contained in the animal feed, are not used for manuring croplands, but are dumped into the urban environment, disregarded or used partly as biofuels (Nigussie et al., 2015; Tadesse et al., 2018). These manure disposal practices may create serious environmental (Horrocks et al., 2016; Tadesse et al., 2018) and human health problems (Jara-Samaniego et al., 2017) and are not sustainable because they waste non-renewable resources (e.g., phosphorus extracted from finite mineral deposits) (Withers et al., 2015). Thus, urban livestock manures and household wastes have to be seen as resources for enhancing crop yields and soil health (Jagisso et al., 2019; Nigussie et al., 2015; Wolka and Melaku, 2015), and for realizing a circular economy (Tadesse et al., 2019).

There are several reasons for not collecting and recycling urban livestock manures and household wastes, even though there is a large need for essential plant nutrients in the rural 
areas (Satterthwaite, 2017; Tadesse et al., 2018, 2019). First, there are cultural barriers and a poor infrastructure. Second, there is lack of data, knowledge and urgency at the policy level, and thus absence of effective policies and incentives for facilitating urban manure and waste recycling. In particular, there is lack of knowledge in urban communities and urban waste management agencies about the quantity and quality of urban livestock manures and household wastes that may be collected and recycled.

The main objective of the current study was to increase the understanding of possible development pathways for urban livestock farming and the recycling of urban livestock manures and household wastes. We selected a small city (Jimma) in Ethiopia for a case study and used survey data and a simple mass flow model to explore possible development pathways toward 2050. Our research questions were (1) how much nitrogen $(\mathrm{N})$ in urban livestock manures will be excreted and household wastes produced in 2050 and how much may be collected and recycled in cropland, (2) what are the expected economic and environmental benefits of the urban manure and household waste collection and recycling, and (3) what is the fertilizer $\mathrm{N}$ replacement value of composts made from animal manures and kitchen wastes. Addressing this last question was based in part on a field experiment in which the effectiveness of urban livestock manures and kitchen waste composts was tested. We focused on $\mathrm{N}$ as key nutrient, although we acknowledge that manures and wastes contain all essential plant nutrients in various proportions as well as organic matter, which are all useful for soil fertility.

\subsection{Materials and methods}

\subsubsection{Study site}

In 2018 , about $20 \%$ of the population in Ethiopia were living in cities, which is less than the African average. Projections indicate that the proportion of urban people will increase to $40 \%$ in 2050. The number of people in cities is expected to increase by on average 3 to $4 \%$ per year (UN, 2019). The capital, Addis Ababa, is the largest city with 3.4 million people in 2018, and there are about 20 cities with 0.1 to 0.4 million people. One of these is Jimma with 0.2 million in the southwest of Ethiopia. It is situated at an altitude of 1780 m.a.s.l. and has a mean rainfall of $1500 \mathrm{~mm} \mathrm{yr}^{-1}$. Wheat, barley, teff, maize, pulses and coffee are the commonest crops, and dairy cattle, goats and poultry the main farmed animal species in urban and peri-urban areas of Jimma city and the surrounding rural areas.

Urban, peri-urban and rural areas differ in population density, built-up areas, infrastructures and key economic activities (Allen, 2003; Opitz et al., 2015). A city center with urban, periurban and rural areas were distinguished around the center (Makita et al., 2010). City centers and urban, peri-urban and rural areas are often an asymmetrical, uneven and multi-dimensional continuum. There are no distinct lines separating the center from peri-urban, urban and rural settings, but often a slow zone of change exists (Lupindu, 2017). For the purpose of our study, we distinguished three zones around the city center of Jimma. Accordingly, Jimma consists of a circular city center surrounded by 5 -km-wide urban and peri-urban zones and a 10-km-wide 
rural zone (Table 5.1), following the concepts and approaches of other researchers (Makita et al., 2010; Opitz et al., 2015; Zhu et al., 2017). We assumed that there was no agriculture in the city center (Abebe et al., 2019).

Table 5.1 Characteristics of the four circular zones of Jimma, Ethiopia in 2015 (after (Tadesse et al., 2019))

\begin{tabular}{lccccc}
\hline Zone & $\begin{array}{c}\text { Total area, } \\
\mathrm{km}^{2}\end{array}$ & $\begin{array}{c}\text { Population, } \\
\text { million }\end{array}$ & $\begin{array}{c}\text { Population } \\
\text { density, } \mathrm{km}^{-2}\end{array}$ & $\begin{array}{c}\text { Agricultural } \\
\text { area, } \%\end{array}$ & $\begin{array}{c}\text { Protein-N yield, } \\
\mathrm{kg} \mathrm{ha}^{-1} \mathrm{yr}^{-1}\end{array}$ \\
\hline City center & 78 & 0.02 & 255 & 0 & Not applicable \\
Urban zone & 235 & 0.10 & 425 & 5 & 75 \\
Peri-urban & 392 & 0.15 & 382 & 20 & 60 \\
Rural & 1256 & 0.12 & 96 & 60 & 40 \\
\hline
\end{tabular}

In 2015 there were about 500 urban and peri-urban livestock farms with, on average, 11.5 tropical livestock units per farm and little or no land and a few hundred crop farms with, on average, 1.5 ha (mainly vegetables, often with some animals) (Tadesse et al., 2019). Three types of livestock production were considered, namely milk (dairy cattle), meat (cattle, goats and poultry) and eggs (poultry); the relative proportions were based on farm surveys (Tadesse et al., 2019). Crop and livestock production was considered to be demand-driven; for 2015 we assumed a mean net protein intake of $17.6 \mathrm{~kg}_{\text {person }}{ }^{-1} \mathrm{yr}^{-1}$ (gross intake $22 \mathrm{~kg}$ person ${ }^{-1} \mathrm{yr}^{-1}$ (Schonfeldt and Hall, 2012); 20\% food losses (Alexander et al., 2017; Ayele and Peacock, 2003; Ghosh et al., 2016)), and that 14\% (Ayele and Peacock, 2003; Enahoro et al., 2018) of the protein intake is animal-derived. Mean net protein intake is below the recommended level but reflects the situation in Africa including Ethiopia (Schonfeldt and Hall, 2012).

\subsubsection{Scenario design}

We designed exploratory scenarios (van Vuuren et al., 2015) and developed a simple N mass flow model (see supplementary information in Appendix 5S) to estimate the effects of possible future developments on the amounts of $\mathrm{N}$ in urban livestock manures and household wastes that may be collected and recycled in cropland between 2015 and 2050, as well as the expected economic costs and environmental benefits of this recycling. Four possible development scenarios were explored: (1) a reference scenario (business as usual; BAU), (2) increased urbanization (URBAN), (3) intensification of UPA, especially livestock production (UPALP), and (4) increased technological development (TECH). The latter three scenarios (variants) were explored separately and combined (Table 5.2).

In BAU the population growth was set at $3 \% \mathrm{yr}^{-1}$ in all four zones and it was assumed that protein consumption capita ${ }^{-1}$, agricultural area, and crop and livestock productivity ha $^{-1}$ will remain constant. In URBAN the population growth in the urban and peri-urban areas was set at $5 \% \mathrm{yr}^{-1}$ and in rural areas at $1 \% \mathrm{yr}^{-1}$ (Table 5.2). Urbanization was associated with a decrease in agricultural land in urban and peri-urban areas, which had implications for manure and waste disposal on agricultural land. UPALP was projected to be implemented through an increase in self-sufficiency in consumption of animal-sourced products in urban and peri-urban areas, from 
20 to $40 \%$ (Ayele and Peacock, 2003; de Bruyn et al., 2016; Workicho et al., 2016). We assumed that $20 \%$ of the required animal feed was scavenged from the neighborhood (roadsides and open markets) and that the other $80 \%$ would come from cropland, based on data from farm surveys (Tadesse et al., 2019). The TECH scenario assumed that the productivity and efficiency of crop and livestock production had doubled and that emission abatement measures were implemented to reduce $\mathrm{N}$ losses from manures and household wastes (Table 5.2).

Table 5.2 Summary overview of the main variables of the scenarios (variants) explored in this study. Urban zones include city center, urban and peri-urban zones (Table 1). UPA refers to urban and peri-urban agriculture. See text and supplementary information for underpinning of the variables

\begin{tabular}{|c|c|c|c|c|c|}
\hline \multirow[b]{4}{*}{ Variable } & \multirow[b]{4}{*}{ Zones } & \multicolumn{4}{|c|}{ Scenarios (variants) } \\
\hline & & \multirow[b]{3}{*}{$\begin{array}{l}\text { Reference } \\
\text { (BAU) }\end{array}$} & \multicolumn{3}{|c|}{$\begin{array}{c}\text { Increased Urbanization } \\
\text { (URBAN) }\end{array}$} \\
\hline & & & & \multicolumn{2}{|c|}{ 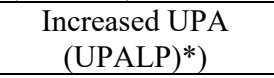 } \\
\hline & & & & & $\begin{array}{l}\text { Enhanced } \\
\text { Technology } \\
\text { (TECH) }\end{array}$ \\
\hline \multirow[t]{2}{*}{ Population growth, $\% \mathrm{yr}^{-1}$} & Urban & 3 & 5 & 5 & 2.5 \\
\hline & Rural & 3 & 1 & 1 & 1 \\
\hline \multirow{2}{*}{$\begin{array}{l}\text { Change in protein consumption, \% } \\
\mathrm{yr}^{-1}\end{array}$} & Urban & 0 & 1 & 1 & 1 \\
\hline & Rural & 0 & 1 & 1 & 1 \\
\hline \multirow{2}{*}{$\begin{array}{l}\text { Change in animal-sourced food } \\
\text { consumption, } \% \mathrm{yr}^{-1}\end{array}$} & Urban & 0 & 1 & 2 & 2 \\
\hline & Rural & 0 & 1 & 1 & 1 \\
\hline \multirow{2}{*}{$\begin{array}{l}\text { Self-sufficiency animal-sourced } \\
\text { food, } \% * *)\end{array}$} & Urban & 20 & 20 & 40 & 40 \\
\hline & Rural & $100+$ & $100+$ & $100+$ & $100+$ \\
\hline \multirow{2}{*}{ Decrease in cropland area, $\% \mathrm{yr}^{-1}$} & Urban & 0 & 2 & 2 & 2 \\
\hline & Rural & 0 & 0 & 0 & 0 \\
\hline Increase in crop yield, $\% \mathrm{yr}^{-1}$ & All & 0 & 3 & 3 & 3 \\
\hline Food waste losses, $\%$ & All & 20 & 20 & 20 & 10 \\
\hline $\begin{array}{l}\text { Feed scavenged from } \\
\text { neighborhood, \% }\end{array}$ & All & 20 & 10 & 10 & 10 \\
\hline Feed $\mathrm{N}$ conversion dairy cattle, $\%$ & All & 10 & 10 & 10 & 20 \\
\hline Feed $\mathrm{N}$ conversion beef cattle, $\%$ & All & 5 & 5 & 5 & 10 \\
\hline Feed $\mathrm{N}$ conversion poultry, $\%$ & All & 20 & 20 & 20 & 40 \\
\hline $\begin{array}{l}\text { Manure \& waste } \mathrm{N} \text { losses during } \\
\text { storage, } \%\end{array}$ & All & 50 & 50 & 50 & 25 \\
\hline $\begin{array}{l}\text { Manure and kitchen waste } \\
\text { collection, } \%\end{array}$ & All & 50 & 50 & 50 & 75 \\
\hline Sewage waste collection, \% & All & 0 & 0 & 0 & 0 \\
\hline Composting losses, \% & All & 30 & 30 & 30 & 30 \\
\hline $\mathrm{N}$ use efficiency of fertilizer $\mathrm{N}, \%$ & All & 40 & 40 & 40 & 60 \\
\hline $\begin{array}{l}\text { Fertilizer } \mathrm{N} \text { effectiveness of } \\
\text { compost, } \%\end{array}$ & All & 40 & 40 & 40 & 60 \\
\hline
\end{tabular}

These measures include doubling the conversion of feed protein into animal-sourced food protein (through breeding and improved feeding), increased manure and kitchen waste 
collection, leak-tight and covered manure storage, and improved agronomic practices, to enhance the $\mathrm{N}$ use efficiency of fertilizer and compost $\mathrm{N}$.

\subsubsection{Calculations}

A simple $\mathrm{N}$ mass flow model was developed in a Microsoft spreadsheet to explore the effects of the scenarios. Calculations were done for the four zones of Jimma (Table 5.1) on an annual basis (2015-2050). The model had four modules: (1) protein consumption and household waste production, (2) milk, meat and egg production and manure production, (3) crop production and $\mathrm{N}$ balances, and (4) economic cost of manure and waste collection, composting and transport. The first three modules were largely based on the NUFER model (Ma et al., 2010; Wang et al., 2018) and followed the principles of mass flow analysis, in this case, of $\mathrm{N}$. The fourth module was developed for the purpose of this study; it considered the costs of manure and waste collection, storage, composting, transport and compost delivery or marketing. Mean cost of compost production was estimated at 500 to $600 \mathrm{ETB} \mathrm{t}^{-1}$ of dry weight, currently equivalent to 15 to $20 \mathrm{USD} \mathrm{t}^{-1}$ of dry weight. This includes the costs for collection, transport, composting and delivery to the market. We assumed that a laborer can collect 2 to $4 \mathrm{t}$ waste or manure per day for free, based on information from locals, labor costs of 5 USD day $^{-1}$ (Caria, 2019), weight losses during composting of 30 to $50 \%$ (Snijders et al., 2009; Tiquia et al., 2002), and additional transport and infrastructural costs of 1 to $5 \mathrm{USD} \mathrm{t}^{-1}$, depending on the area. The cost estimates were derived from interviews with locals; these estimates are uncertain, also because there are no existing commercial services for manure and waste collection, storage, composting, transport and delivery/marketing.

The model accounts for additional $\mathrm{N}$ inputs (via biological $\mathrm{N}_{2}$ fixation and fertilizers), recycling of manure and waste $\mathrm{N}$ in cropland, and for $\mathrm{N}$ losses during manure and waste storage and composting and following application to cropland. One compound crop yield per zone was defined, which was either kept constant (in BAU) or increased over time (in the other scenarios; Table 5.2). The required additional $\mathrm{N}$ input via biological $\mathrm{N}_{2}$ fixation and mineral $\mathrm{N}$ fertilizers (N-inputN; $\mathrm{kg} \mathrm{ha}^{-1} \mathrm{yr}^{-1}$ ) was estimated from the following mass balance: $\mathrm{N}$-input $\mathrm{N}_{\mathrm{N}}=$ crop protein-N yield * $\mathrm{NUE}^{-1}-\left(\mathrm{N}\right.$-input $\left.{ }^{*} \mathrm{FRV}_{\mathrm{M}}\right)$, where $\mathrm{N}$-input $\mathrm{M}$ is the $\mathrm{N}$ input via manure and composts $\left(\mathrm{kg} \mathrm{ha}^{-1} \mathrm{yr}^{-1}\right), \mathrm{FRV}_{\mathrm{M}}$ is the fertilizer $\mathrm{N}$ replacement value of manures and composts ( $\%$, ranging from 40 to $60 \%$; Table 5.2), and NUE is the $\mathrm{N}$ use efficiency in crop production ( $\%$, ranging from 40 to $60 \%$; Table 5.2). Farm-gate balances were derived from the difference between the inputs via imported animal feed (in UPA) and additional $\mathrm{N}$ (via biological $\mathrm{N}_{2}$ fixation and mineral fertilizer), and the output of harvested crop and animal produce. A surplus on the farm-gate $\mathrm{N}$ balance reflects $\mathrm{N}$ losses via ammonia volatilization, nitrate leaching and denitrification. We assumed that the soil was not a (temporary) net source of $\mathrm{N}$ (there was no soil $\mathrm{N}$ mining), also not a net sink of $\mathrm{N}$ (there was no soil $\mathrm{N}$ sequestration). The Microsoft spreadsheet model is available as a supplementary material in Appendix 5S. 


\subsubsection{Field experiment}

Field experiments were conducted in 2015 and 2016 to estimate the fertilizer $\mathrm{N}$ replacement value of composts derived from cattle and poultry manure and kitchen waste. The study was conducted at Jimma University research station (see supplementary information in Appendix $5 \mathrm{~S}$ for research site description).

The field experiment was conducted as randomized complete block design with 13 treatments (Table 5.S3). Treatments included three references (i.e., T1, unfertilized control; T2, half the recommended $\mathrm{N}$ and $\mathrm{P}$ application; and T3, full recommended $\mathrm{N}$ and $\mathrm{P}$ application, that is 100 $\mathrm{kg} \mathrm{ha}^{-1}$ of diammonium phosphate (DAP) and $100 \mathrm{~kg} \mathrm{ha}^{-1}$ of urea (Elias et al., 2019; Tilahun and Tamado, 2019)), and five types of composts (prepared from chicken manure, cattle manure, pig manure, farm yard manure and kitchen waste) applied at two rates (Table 5.S3). Composts were collected at local farms. Each treatment was replicated four times. DAP contained 18\% $\mathrm{N}$ and $20 \% \mathrm{P}$ and urea contained $46 \% \mathrm{~N}$. In both years, the experimental field was plowed using oxen-drawn implements and manually prepared for sowing. Wheat cv. HAR 3116 was the test crop and planted with $0.3 \mathrm{~m}$ row spacing. Plot size was $4 \times 3=12 \mathrm{~m}^{2}$. Composts and fertilizers were applied in planting rows a day before sowing. In 2015, grain and straw yields were recorded at harvest, and in 2016, whole plant samples were collected at booting stage (stage 10 of the Feekes development scale) from 50 randomly selected plants per plot for plant analysis (see supplementary information in Appendix 5S).

Results of the field experiments were used to estimate: harvest index (\%), apparent agronomic efficiency $\left(\mathrm{kg} \mathrm{kg}^{-1}\right)$, apparent $\mathrm{N}, \mathrm{P}$ or K recovery efficiencies (\%), partial factor productivity $\left(\mathrm{kg} \mathrm{kg}^{-1}\right.$ ), and the fertilizer replacement value (FRV, \%) of composts (see supplementary information in Appendix 5S). 


\subsection{Results}

\subsubsection{Simulated changes in demography and food self-sufficiency}

With a net population growth rate of $3 \% \mathrm{yr}^{-1}$ in the BAU scenario, Jimma will have a total population of 1.1 million in 2050 of which $70 \%$ will be living in urban and $30 \%$ in rural areas. In the URBAN scenario, with a population growth of $5 \% \mathrm{yr}^{-1}$ in urban and $1 \% \mathrm{yr}^{-1}$ in rural areas (Table 5.2), Jimma will have 1.7 million people in 2050 , with $90 \%$ living in urban areas (Figure 5.1).
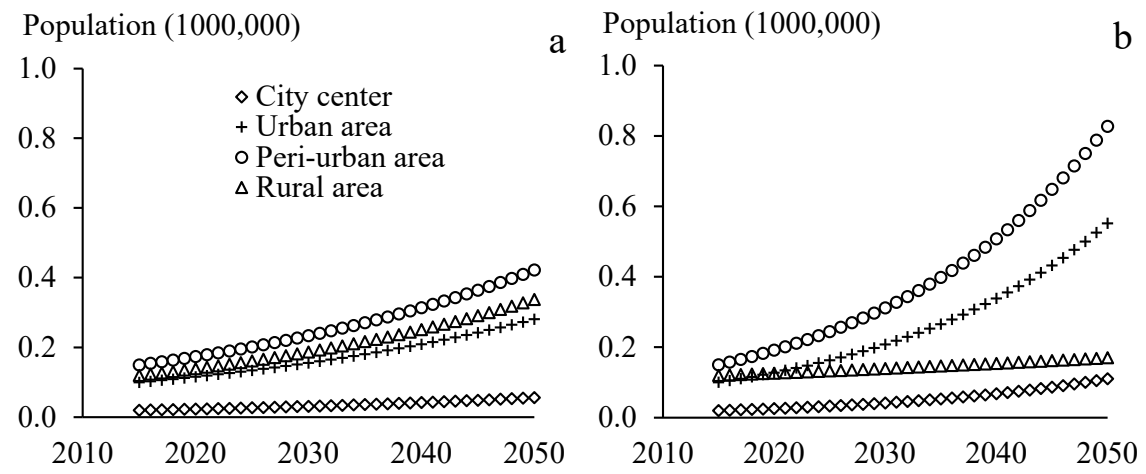

Figure 5.1 Simulated changes in the number of people in the various zones in Jimma between 2015 and 2050 for (a) Reference (BAU) scenario, and (b) Urbanization (URBAN) scenario (See Table 5.2 for assumptions).

The rural area produced a surplus of food in 2015 which also covered the demand by the urban dwellers. With rapid population growth and stagnant yields in the BAU scenario, food selfsufficiency of the whole city area will decrease to $35 \%$ in 2050 (Figure 5.2a). In the URBAN scenarios we assumed a steady crop yield increase of $3 \% \mathrm{yr}^{-1}$ (Cochrane and Bekele, 2018; Taffesse et al., 2011) (Table 5.2), but because of the increased population growth, food selfsufficiency will drop below $100 \%$ indicating the need to import food. To be able to remain food self-sufficient, population growth will have to be limited to $2.5 \% \mathrm{yr}^{-1}$, crop productivity will have to increase by $3 \% \mathrm{yr}^{-1}$ (Cochrane and Bekele, 2018; Taffesse et al., 2011), and animal (dairy and beef cattle and poultry) productivity in terms of feed protein-N conversion (Table 5.2) has to double, as indicated in the TECH scenario (Figure 5.2d; Table 5.2). Further, animalderived protein intake has to be limited to no more than $20 \%$. 

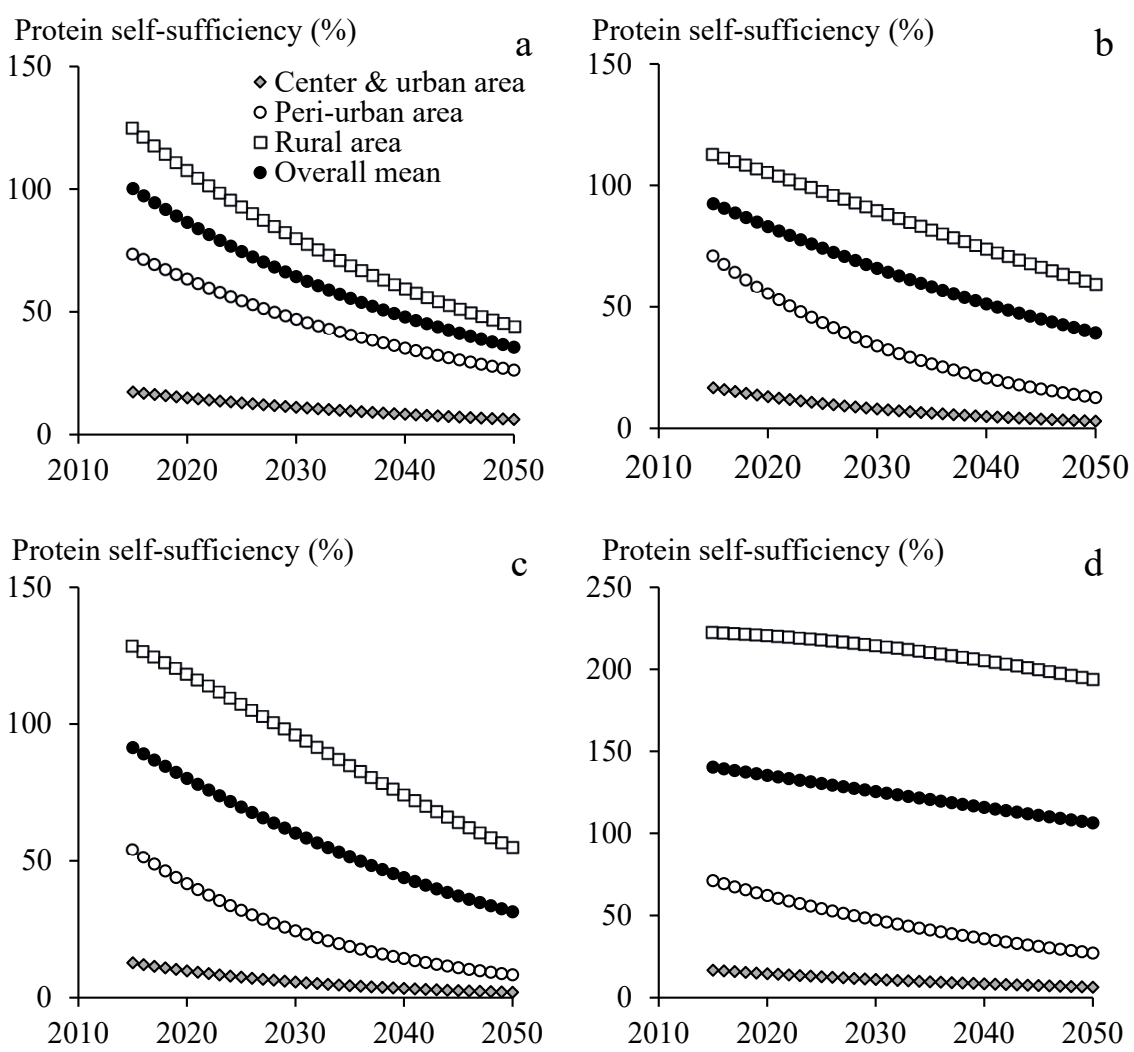

Figure 5.2 Simulated changes in the self-sufficiency of crop production, to cover the demands for plant food and animal feed in the various zones in Jimma between 2015 and 2050 for four scenarios: (a) BAU, (b) URBAN, (c) UPALP, and (d) TECH (see Table 5.2 for assumptions). Self-sufficiency is defined here as the ratio of domestic production to total consumption (or demand); the latter is assumed to be equal to domestic production plus net imports. Selfsufficiency was $100 \%$ for the whole area in 2015 , using the data presented in Table 5.1, and assuming a net protein intake of $17.6 \mathrm{~kg} \mathrm{cap}^{-1} \mathrm{yr}^{-1}$, with $14 \%$ animal-sourced food.

\subsubsection{Waste and manure production}

The modeled demographic changes had large impacts on the total mass of waste and manure $\mathrm{N}$ production. In the BAU scenario, total household waste $\mathrm{N}$ production and manure $\mathrm{N}$ excretion will almost triple between 2015 and 2050 (Figure 5.3a). Animal manure N (cattle, goats and poultry) contributed $67 \%$, kitchen waste $7 \%$ and sewage waste $26 \%$ to the total $\mathrm{N}$ production. Household waste production will be greatest in the urban and peri-urban zones, while manure $\mathrm{N}$ excretion will be the greatest in the rural area; $18 \%$ of the manure will be produced by UPA livestock farms.

Household waste and manure $\mathrm{N}$ production will increase much faster in the URBAN scenario than in the BAU scenario (Figure 5.3b). The projected increase was most notable in the urban 
and peri-urban areas of the UPALP scenario (Figure 5.3c), because $37 \%$ of the total manure production will occur in the urban area (and $63 \%$ in the rural area). Animal manure will contribute $73 \%$ to the total production of waste and manure $\mathrm{N}$, i.e., $6 \%$ more than in the BAU scenario because of the assumed increase in animal-sourced protein consumption (14 to 19\%). Total waste and manure $\mathrm{N}$ production will be lower in the TECH scenario than in the other scenarios (Figure 5.3d) due to reduced population growth, halving of food wastes, and doubling of animal productivity (Table 5.2).
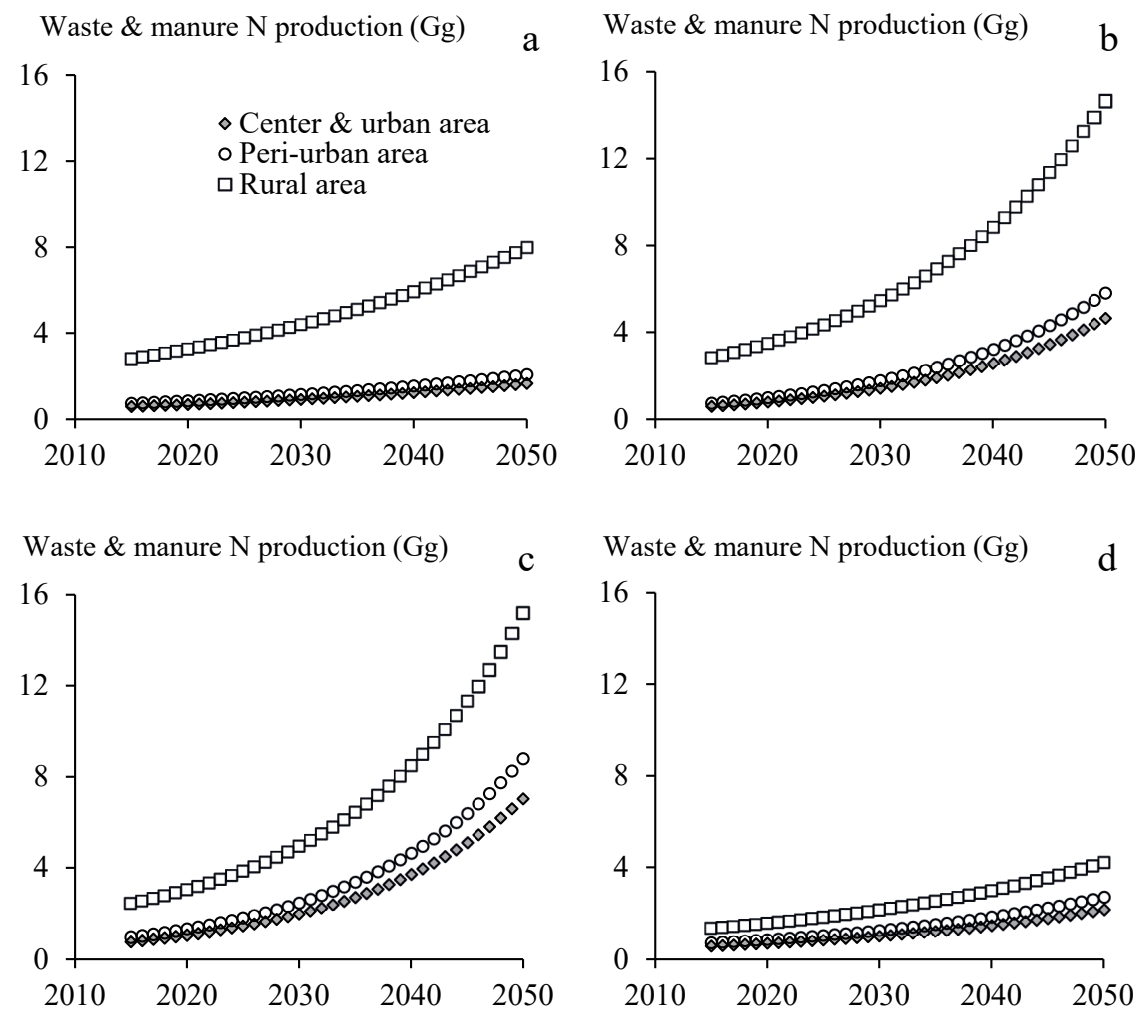

Figure 5.3 Simulated changes in the total production of household wastes (kitchen and sewage) and animal manures from livestock in different zones of Jimma, Ethiopia for 2015 to 2050 in four scenarios: (a) BAU, (b) URBAN, (c) UPALP and (d) TECH (see Table 5.2 for assumptions). Note, there was no livestock production in the city center.

\subsubsection{Waste and manure recycling}

Only $18 \%$ of the amount of $\mathrm{N}$ in manures and kitchen wastes will be recovered as compost for recycling to cropland in the BAU scenario (Figure 5.4a). The remainder will be lost during storage and composting or not collected; we assumed that $50 \%$ will be collected (Table 5.2). Similar losses were assumed in the URBAN and UPALP scenarios (Figure 5.4b, 5.4c). 

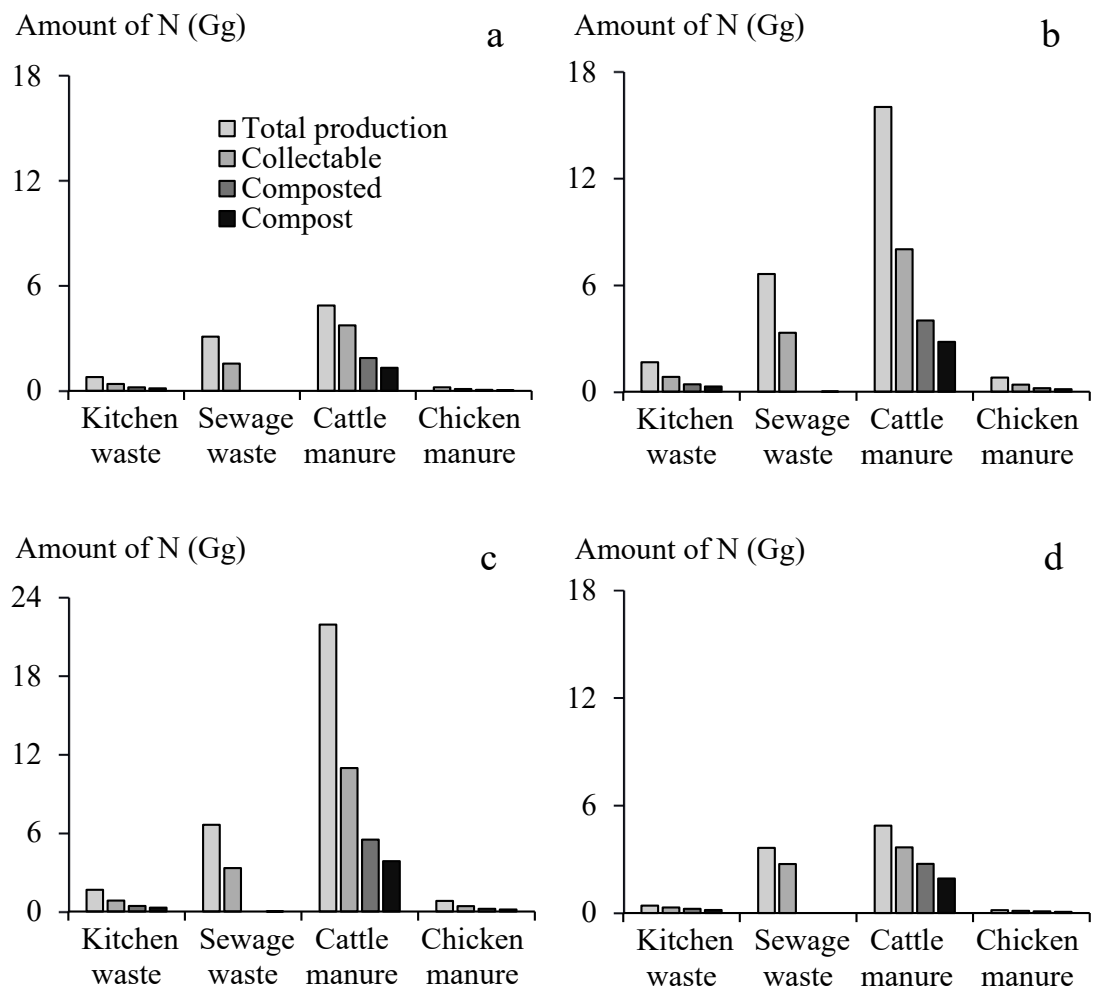

Figure 5.4 Calculated amounts of nitrogen $(\mathrm{Gg})$ in kitchen wastes, sewage wastes, cattle manures and chicken manures that will be produced, collected, composted, and recycled as compost in Jimma, Ethiopia in 2050 in four scenarios: (a) BAU, (b) URBAN, (c) UPALP and (d) TECH (see Table 2 for assumptions). Note the different $\mathrm{Y}$-axis of figure $\mathrm{C}$.

No $\mathrm{N}$ from sewage waste is likely to be recovered because of cultural barriers. Losses of $\mathrm{N}$ from wastes and manures will occur during storage (estimated at 50\%) (Snijders et al., 2009), during collection (estimated at 50\%), mainly through neglect and disregard, and during composting (estimated at 30\%), possibly through $\mathrm{NH} 3$ volatilization, denitrification, leaching and runoff. In the TECH scenario we estimated that $39 \%$ of the $\mathrm{N}$ from kitchen wastes and manures will be recovered (Figure 5.4d) because of improved collection and the use of emission mitigation techniques (Table 5.2).

The total amount of compost $\mathrm{N}$ available in 2050 is likely to range between $1.5 \mathrm{Gg}$ (in the $\mathrm{BAU}$ ) and $4 \mathrm{Gg}$ (URBAN and UPLP) (Figure 5.4). About $2 \mathrm{Gg} \mathrm{N}$ would be recovered as compost in the TECH scenario, indicating that the reduction in waste and manure production outweighed the effects of emission mitigation and improved collection. Manures will have a share of about $90 \%$ in compost production (Figure 5.4 ), with about $36 \%$ originating from UPA livestock farms. 
The total cost of compost production will increase (Figure 5.5) because the volume of compost increases but also because of assumed inflation $\left(1 \% \mathrm{yr}^{-1}\right)$. The costs of compost, estimated at 500 to $600 \mathrm{ETB} \mathrm{t}^{-1}$ of dry weight, currently equivalent to 15 to $20 \mathrm{USD} \mathrm{t}^{-1}$ of dry weight, would lead to a competitive price by when considering the amount of nutrients in the composts and the price of mineral NPK fertilizers without subsidies: 426 USD t $^{-1}$ of DAP and 355 USD t $^{-1}$ of urea. Costs of composting were expected to increase threefold in the TECH scenario because of the investments in sheltered barns with leak-tight floors, and leak-tight and covered manure stores. These investments increased the fraction of waste and manure $\mathrm{N}$ recovered in compost (Figure 5.5d), and the $\mathrm{N}$ content of the compost, but made the compost less competitive relative to mineral fertilizers.
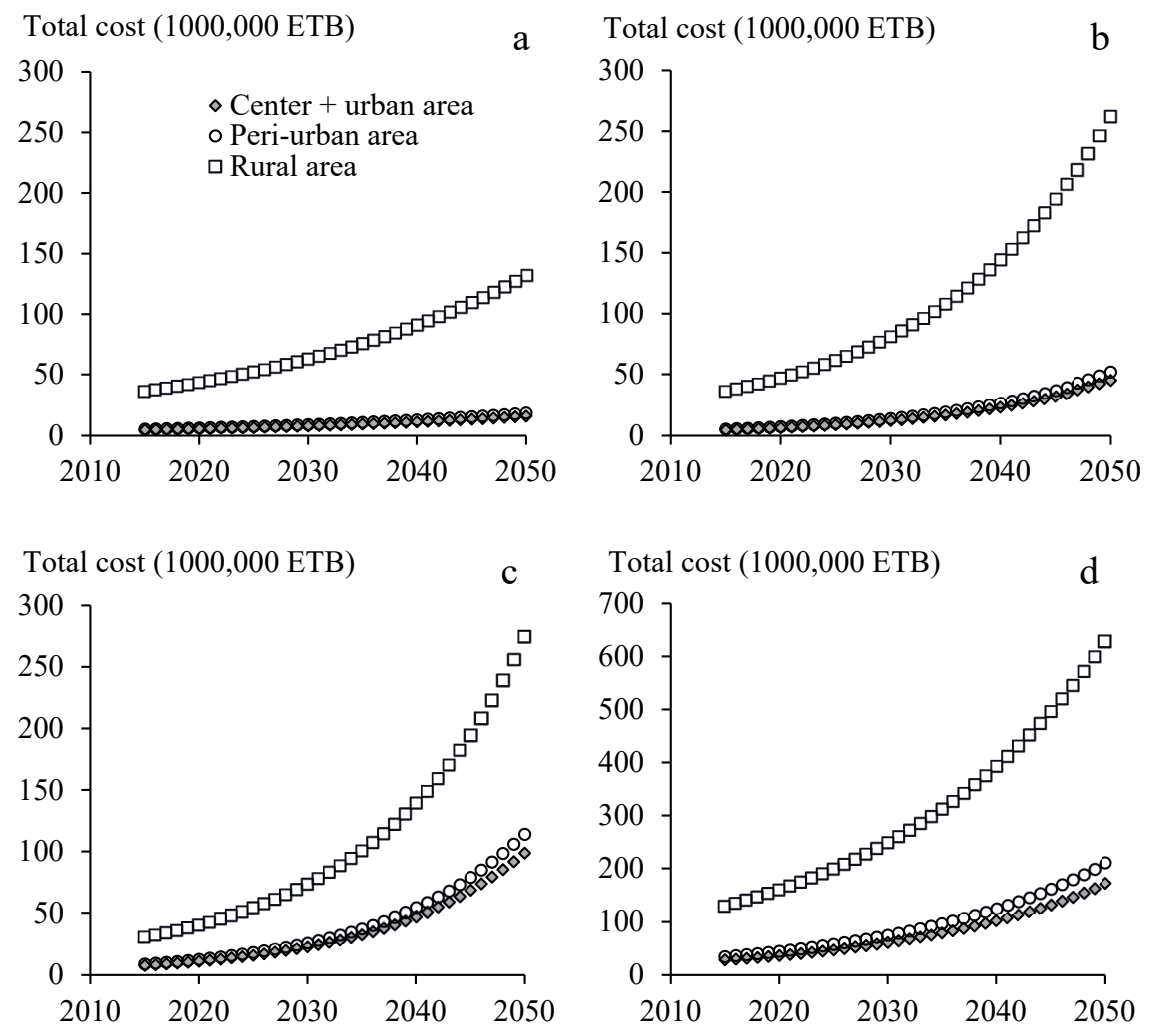

Figure 5.5 Simulated changes in the total cost of collection, composting and transport of kitchen wastes and animal manures in different recycling zones of Jimma, Ethiopia for 2015 to 2050 in four scenarios: (a) BAU, (b) URBAN, (c) UPALP, and (d) TECH (see Table 5.2 for assumptions). Note the different $\mathrm{Y}$-axis in D. 


\subsubsection{Fertilizer $\mathbf{N}$ replacement value of composted manures and wastes}

Results of the field experiments show that nutrient (N, P and K) contents of wheat plants at booting stage were significantly $(P<0.05)$ enhanced by most compost treatments (Table 5.S4). Chicken manure compost was most effective in enhancing the N, P and K contents at booting stage. The $\mathrm{N}$ contents of wheat plants at booting stage were close to the agronomic sufficiency range of 20 to $30 \mathrm{~g} \mathrm{~kg}-1$ for $\mathrm{N}, 2$ to $5 \mathrm{~g} \mathrm{~kg}-1$ for $\mathrm{P}$ and 15 to $30 \mathrm{~g} \mathrm{~kg}-1$ for $\mathrm{K}$ (Rodd et al., 2002). There was a relatively large within-treatment variation in $\mathrm{N}, \mathrm{P}$ and $\mathrm{K}$ contents and a significant block effect in $\mathrm{N}$ and $\mathrm{K}$ contents (Table 5.S5), which was likely the result of spatial variation in soil fertility. Most compost treatments increased grain and straw yields and $\mathrm{N}, \mathrm{P}$ and $\mathrm{K}$ uptake compared to the unfertilized control (Table 5.S6). The apparent agronomic efficiency and the apparent $\mathrm{N}$ recovery were on average lower in compost treatments than in the DAPurea reference treatments, for both $\mathrm{N}$ and $\mathrm{P}$, indicating that the composts were less effective per unit of applied nutrient in enhancing grain yield than the synthetic fertilizers (Table 5.S7).

The fertilizer $\mathrm{N}$ replacement value was about $30 \%$ for composts derived from cattle manures, farmyard manures and kitchen wastes, and about $60 \%$ for composts derived from poultry and pig manures (Figure 5.6). Based on these results, we assumed a compost $\mathrm{N}$ efficiency value of $40 \%$ in the BAU scenario and $60 \%$ in the TECH scenario.

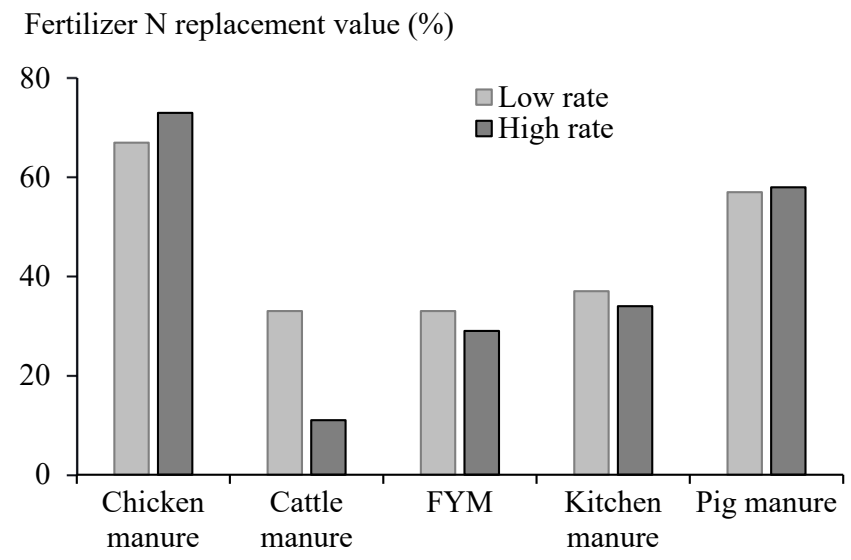

Figure 5.6 Fertilizer $\mathrm{N}$ replacement values of composts from different sources, as derived from the results of the field experiments in Jimma, Ethiopia, in which the composts were applied at low and high application rates.

\subsubsection{Nitrogen input-output balances}

Simulated farm-gate N input-output balances were much higher in the UPA than in the rural area (Figure 5.7). In the BAU scenario, $\mathrm{N}$ surplus in the UPA will increase from $240 \mathrm{~kg} \mathrm{ha}^{-1}$ in 2015 to $480 \mathrm{~kg} \mathrm{ha}^{-1}$ in 2050 , and in the rural area from 90 to $150 \mathrm{~kg} \mathrm{ha}^{-1}$. Farm-gate $\mathrm{N}$ surpluses in the UPA will increase rapidly in the URBAN and UPALP scenarios, especially in the urban 
areas (Figure 5.7b, 5.7c) because of the increasing urban food demand and the corresponding intensification of urban livestock production. Increases will be much less in the TECH scenario (Figure 5.7d) because of the assumed increase in food production efficiency and use of emission mitigation techniques. Calculated soil $\mathrm{N}$ balances (not shown) will be 1.5 to 5.5 times less than the farm-gate $\mathrm{N}$ balances in the UPA; this large difference reflects the loss of $\mathrm{N}$ from manures at the farmstead, i.e., from manure stores.
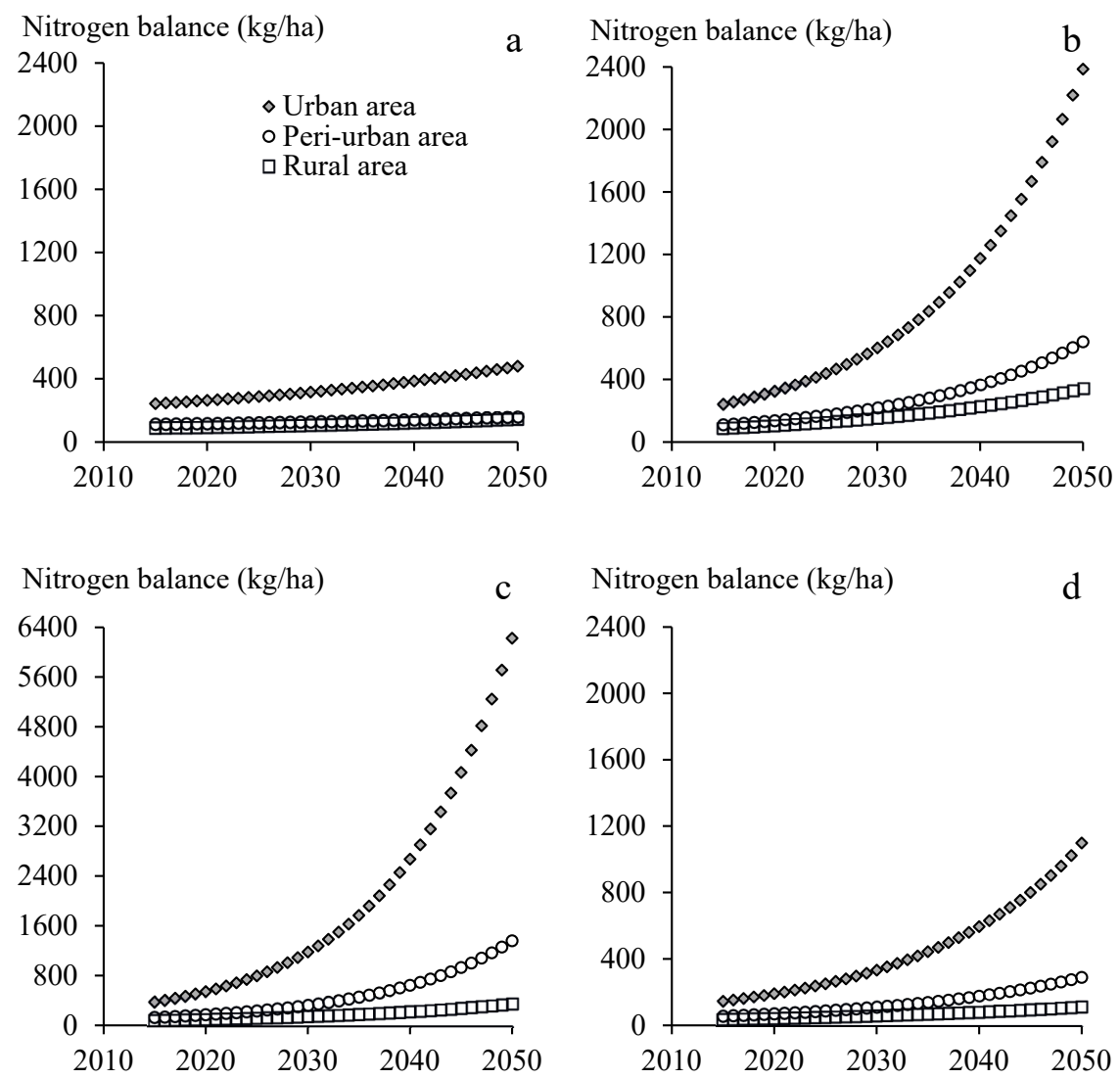

Figure 5.7 Simulated changes in the $\mathrm{N}$ input-output balance of agriculture in different zones of Jimma, Ethiopia for 2015 to 2050 in four scenarios: (a) BAU, (b) URBAN, (c) UPALP, and (d) TECH (see Table 5.2 for assumptions). Note the different Y-axis in C.

The $\mathrm{N}$ output/input ratio of the whole food production-consumption chain was 0.13 in BAU in 2015 (Figure 5.S2), indicating that an intake of $1 \mathrm{~kg}$ protein-N by Jimma residents required the input of $7.7 \mathrm{~kg}$ of additional $\mathrm{N}$ on average (Ma et al., 2010; Ma et al., 2013b). The ratio will increase to 0.37 in BAU in 2050, reflecting an increase in the import of food from elsewhere (and hence the neglect of the $\mathrm{N}$ cost of producing that food). The $\mathrm{N}$ output/input ratio of the whole food chain will be 0.22 to 0.26 in the TECH scenario because of the more effective recycling of manure and waste $\mathrm{N}$ in crop production. 


\subsection{Discussion}

\subsubsection{Importance of urban livestock farming}

UPA is important for nutritional security and poverty alleviation of urban households in Africa, and its importance is increasing over time (FAO, 2011). It has been suggested that the nutritional benefits of UPA livestock production outweigh the health risks involved (LeeSmith, 2010), though the latter cannot be ignored (Alarcon et al., 2017). Urban livestock farming in Africa is highly diverse in primary farming objectives including a survival strategy for poor urban residents and also increased income by established urban residents (Tadesse et al., 2018), but dominated by smallholders (Robinson et al., 2011b; Wilson, 2018). This contrasts with the increasing number of large specialized animal feeding operations in urban and peri-urban areas in countries with emerging economies such as China (Wei et al., 2015), where the specialized pig and poultry farmers often partner with animal breeding or feeding companies (contract farmers). Basically, most UPA livestock farms around the world have a relatively high farm income from a small farm area (Tadesse et al., 2018, 2021; Wei et al., 2015), and specialization and intensification are common trends (Bai et al., 2018b; Roessler et al., 2016a). Common features of UPA livestock farms are also the need to import a large fraction of the required feed from elsewhere and the shortage of land for rational manure disposal. As a consequence, UPA livestock farms often have large manure nutrient surpluses (Abdulkadir et al., 2013; Tadesse et al., 2018, 2021), as was the case in Jimma especially in the URBAN and UPALP scenarios (Figure 5.7).

Scenario analysis is an important tool in exploring the effects of possible alternative developments for waste management during urbanization and UPA intensification (Arushanyan et al., 2017). Increased recycling of organic wastes to supplement crop nutrient demand is an essential component of sustainable food systems (Akram et al., 2019) and entails the concept of the circular economy (Diacono et al., 2019). We built and used a simple N mass flow model for a circular city with four zones to explore possible development pathways of UPA and manure $\mathrm{N}$ recycling in Jimma, one of the many small but rapidly growing cities in Ethiopia (and other countries in Africa). The model was effective in examining the relationships between population growth, urbanization, UPA intensification, food production self-sufficiency and the recycling of $\mathrm{N}$ from manures and wastes during the next few decades. The size of the rural area around Jimma was chosen such that the overall mean population density in the four zones in 2015 was similar $\left(200 \mathrm{~km}^{-2}\right)$ to the mean population density in those areas of Ethiopia where most people live and where most of the food is produced. Thus, the cropland and rural areas may not be extended easily when population increases in Jimma; it would be at the expense of other people's needs.

Total manure $\mathrm{N}$ production in the urban and peri-urban areas will likely increase by 3 to 10 times over the next three decades. Increases were especially large in the URBAN and UPALP scenarios (Figure 5.3) as a result of the expected population growth, urbanization and UPA intensification. Manure N production had an estimated share of 56 to $73 \%$ in the total waste 
and manure production in Jimma, even though animal-sourced protein was only a small fraction ( $14 \%$ to $19 \%$ ) of the total protein intake of residents, which is below the world average but close to the animal-sourced protein intake recommended from environmental points of view (Clark and Tilman, 2017; Lonnie et al., 2018). Kitchen wastes had a share of 4 to $7 \%$ and sewage wastes of 21 to $40 \%$ in the total manure and waste N production. Manures from UPA livestock farms were the main source of organic wastes in the urban environment, and are the targeted resource for nutrient recycling. Though sewage waste was also a significant source of $\mathrm{N}$ (and other nutrients and organic carbon), we did not consider its recycling because of cultural barriers. Neglecting the recycling of human waste leads to a loss of plant nutrients (Spangberg et al., 2014).

Urbanization and UPA intensification strongly increased the farm-gate $\mathrm{N}$ balance of UPA (Figure 5.7). The farm-gate $\mathrm{N}$ balance is an indicator of the pressure of agriculture on the environment (Ma et al., 2013b; Sassenrath et al., 2013). Clearly, the pressure on the environment will greatly increase over time in the URBAN and UPALP scenarios to a level where the livestock farms will become major sources of environmental pollution unless drastic measures are adopted, as examined in the TECH scenario (Figure 5.3d).

Three main changes were incorporated in the TECH scenario, i.e., a halving of the urban population growth, a doubling of animal productivity (doubling of feed protein- $\mathrm{N}$ conversion) and $\mathrm{N}$ use efficiency in crop production, and a halving of food wastes and $\mathrm{N}$ losses from manure stores. Reducing the population growth in the urban area from $5 \%$ to $2.5 \%$ and doubling animal productivity will be needed to achieve self-sufficiency of crop protein production and to cover the demands for plant food and animal feed (Figure 5.2). Doubling animal productivity via doubling the feed protein- $\mathrm{N}$ conversion also halved manure $\mathrm{N}$ production, and combined with a 50\% reduction in manure $\mathrm{N}$ losses greatly contributed to a reduced growth of the $\mathrm{N}$ surpluses (Figure 5.7). Clearly, drastic improvements in productivity and $\mathrm{N}$ use efficiency of UPA livestock farming will greatly contribute to food self-sufficiency and environmental sustainability.

\subsubsection{Recycling manure $\mathrm{N}$ from urban livestock farms}

Many UPA livestock farms in Ethiopia do have some land for cropping, grazing and manure disposal (Tadesse et al., 2018, 2021), but the area is insufficient to provide the required feed and to dispose of all the manure in an agronomically and environmentally sound manner. Therefore, most of the feed is imported from the rural areas, but we assumed that $20 \%$ of the required feed of UPA livestock will be scavenged from the neighborhood, based on earlier surveys (Tadesse et al., 2019). Unexpectedly, the amount of manure $\mathrm{N}$ that may be recovered in compost in the urban area was insufficient to cover the total $\mathrm{N}$ demand by all cropland in the urban area according to our model calculations. The shortage of $\mathrm{N}$ is related to the relatively high $\mathrm{N}$ demand of the cropland and the poor manure $\mathrm{N}$ recycling efficiency; in BAU only $18 \%$ and in TECH $38 \%$ of the excreted $\mathrm{N}$ in manure is recovered as compost, and utilized with a fertilizer $\mathrm{N}$ replacement value of $40 \%$ (Table 5.2; Figure 5.6). This poor recycling efficiency 
is consistent with a literature review that indicates that $\mathrm{N}$ losses from manure stores in Africa range roughly from 40 to $70 \%$, depending on manure quality and storage conditions (Snijders et al., 2009). A large fraction is not collected and recycled because of various barriers (Marshall and Farahbakhsh, 2013). In BAU, a total of $0.34 \mathrm{Gg} \mathrm{N}$ will be recovered as compost $\mathrm{N}$ in the urban and peri-urban areas by 2050 . The amount of compost $\mathrm{N}$ will be $1.73 \mathrm{Gg} \mathrm{N}$ in the UPALP scenario, and $0.8 \mathrm{Gg} \mathrm{N}$ in the TECH scenario. These numbers compare fairly well with estimates of the manure recycling potential in other East African cities currently, e.g., Nairobi (De Zeeuw et al., 2011) and Kampala (Komakech, 2014).

In addition to the large losses and poor recycling efficiency of the wastes and animal manures (Figure 5.S2), the fertilizer $\mathrm{N}$ replacement value of the composts was relatively low. The nutrient supply from organic amendments to crops is usually expressed as a fertilizer replacement value. A proper comparison per nutrient element requires that other essential nutrients are not limiting crop yield and nutrient uptake, following the ceteris paribus principle (Hijbeek et al., 2018). However, we were interested in the overall fertilization effect of the compost; the apparent fertilizer $\mathrm{N}$ replacement value of the composts examined in the field experiment ranged from 11 to $73 \%$ (Figure 5.6). Compost type was more important than compost application rate according to our field experiment. Grain yield of the control treatment was low, indicating that the site had low inherent soil fertility (Table 5.S6) and thus we expected a high fertilizer $\mathrm{N}$ replacement value (close to $100 \%$ ) because of the multiple nutrients applied in compost (Chen et al., 2018; Zhang et al., 2020b). However, the fertilizer N replacement value was on average much less than $100 \%$, likely because a large fraction of the $\mathrm{N}$ was organically bound and had to be mineralized before becoming available to crops (Rufino et al., 2006; Webb et al., 2013). A strategy with integrated application of compost and mineral fertilizer would likely lead to a higher $\mathrm{N}$ use efficiency. Likely, the fertilizer $\mathrm{N}$ replacement values of the compost will increase over time, when applications will be continued (Komakech, 2014). Further, the response was variable, which was likely related to spatial variation in soil fertility and to the heterogeneity of the composts.

Compost applications did reverse the negative $\mathrm{N}, \mathrm{P}$ and $\mathrm{K}$ balances of the control treatment to positive balances (Table 5.S7), indicating that recycling of composts contributes to reversing soil mining, which is the current practice in rural areas (Krause and Rotter, 2018; Tadesse et al., 2018). The possible presence of plastics, pollutants, pharmaceutical compounds and veterinary products such as hormones and antibiotics in manures and wastes are sometimes challenges for environmentally sound recycling practices (Hou et al., 2017; Manyi-Loh et al., 2016; Martens and Bohm, 2009) and food safety (Bernal, 2017; Verma et al., 2016). The impact of plastic waste is currently increasing in urban areas (Comanita et al., 2016; Verma et al., 2016).

\subsubsection{Costs and benefits of recycling manures}

Recycling manures may have multiple benefits including soil fertility replenishment, increasing crop yields, fertilizer savings, and diminishing environmental pollution associated 
with dumping and/or disregarding manures. However, the manures have to be collected, stored properly and applied to cropland at the right place and time, and in the right amounts, to be able to provide these benefits. There is also competition from alternative uses in the rural areas (building materials and biofuel). Subsidizing mineral fertilizers in Ethiopia also does not facilitate manure recycling, although there are various constraints to transporting the fertilizers to the rural areas (Croppenstedt et al., 2003; Holden, 2019).

The calculated cost of recycling manures will increase over time because the amounts of manure will increase. Most costs are for the rural area because most manure is produced there, also in the UPALP scenarios (Figure 5.5). The introduction of covered and leak-tight manure stores and increased manure collection efficiency in the TECH scenario (Table 5.2; Figure 5.4d) will increase the cost of compost (Figure. 5.5d) threefold and make the compost less competitive relative to mineral fertilizers. The cost of covered and leak-tight manure stores was estimated to be relatively high per unit of composted manure because of the high number of smallholdings. The question is whether such investments can be made economically attractive for smallholders. Another question is whether the future is more in the direction of mixed croplivestock farms with sufficient land for manure disposal, or in the direction of large technicallyadvanced and confined animal feeding operations with high manure $\mathrm{N}$ recovery efficiency potential.

The results of the current scenario analyses are not free of uncertainties. We made several assumptions and gross simplifications for estimating possible future developments and pathways. Uncertainties arise from the assumptions of model parameters, population growth, crop yields, cropping areas, number of farms and animals, and the economic costs of manure and waste collection, composting and redistribution. The livestock sector responds to changes in local and global markets, availability of new technology, and government policies. Conflicts and migration may also play a role. Thus, more dynamic modeling approaches, more diverse scenarios and also consideration of long-term effects of manure and fertilizer applications on soil fertility will be needed (Zoboli et al., 2016) in future studies.

\subsection{Conclusions}

Urbanization and intensification of UPA livestock production are partly entwined in Africa. Both are driven by population growth and have large effects on regional food self-sufficiency and on the potential for recycling of manures and wastes over the next few decades as indicated by our scenario analyses for Jimma, a small city in Ethiopia. Livestock manure was by far the main organic waste in the urban and peri-urban areas, even though only 20 to $40 \%$ of animalsourced food consumed was produced in those areas and only 14 to $19 \%$ of the protein intake by the people was animal-sourced. Manure production in the urban and peri-urban areas is expected to increase by 3 to 10 times from 2015 to 2050 depending on scenario, but only about 13 to $38 \%$ of the manure $\mathrm{N}$ will be recycled in cropland according to our model calculations. 
The expected population growth of 3 to $5 \%$ per year is threatening the food self-sufficiency of Jimma over the next few decades, even under the assumption of an annual increase of $3 \%$ in compound crop yields. At the same time, mean farm-gate $\mathrm{N}$ balances of UPA farms will increase to over $1 \mathrm{t} \mathrm{ha}^{-1}$ in 2050 because of the enhanced import of animal feed, and thus are threatening the environmental sustainability of the food system.

The TECH scenario highlights three important messages for diminishing the pressures on food security and environmental sustainability: (1) the need for reduced population growth and urbanization (family planning policy and health extension to control unprecedented population growth, the related rural-urban migration and urban population growth in Ethiopia), (2) the need to substantially increase crop and livestock productivities (feed conversion efficiency and $\mathrm{N}$ use efficiency), and (3) the need to substantially improve manure and waste recycling through improved collection and reduced losses during storage. The first two have greater impacts on diminishing the identified pressures than the last one.

Although the costs of manure and waste recycling will increase greatly, our modeling indicates that the cost of the resulting composts will be comparable to the cost of mineral fertilizers, per unit of $\mathrm{N}$ and $\mathrm{P}$, which suggests that the composts would be economically compatible. However, it is possible that little waste and manure from the urban and peri-urban areas will be recycled because of informational, cultural and technical barriers, which highlights the need for incentives from government. There is a need for real-world validation and further exploration using more refined models and farm survey data. There is also a need for discussions with stakeholders and policymakers. 


\section{Chapter 5}

\section{References:}

Abdulkadir A., Leffelaar P.A., Agbenin J.O., Giller K. E. (2013) Nutrient flows and balances in urban and peri-urban agroecosystems of Kano, Nigeria. Nutrient Cycling in Agroecosystems 95: 231-254.

Abebe M.S., Derebew K.T., Gemeda D.O. (2019) Exploiting temporal-spatial patterns of informal settlements using GIS and remote sensing technique: a case study of Jimma city, Southwestern Ethiopia. Environmental Systems Research 8.

Agegnehu G., Amede T. (2017) Integrated Soil Fertility and Plant Nutrient Management in Tropical Agro-Ecosystems: A Review. Pedosphere 27: 662-680.

Akram U., Quttineh N.H., Wennergren U., Tonderski K., Metson G.S. (2019) Enhancing nutrient recycling from excreta to meet crop nutrient needs in Sweden-a spatial analysis. Sci Rep 9: 10264.

Alarcon P., Fevre E.M., Muinde P., Murungi M.K., Kiambi S., Akoko J., Rushton J. (2017) Urban Livestock Keeping in the City of Nairobi: Diversity of Production Systems, Supply Chains, and Their Disease Management and Risks. Front Vet Sci 4: 171.

Alexander P., Brown C., Arneth A., Finnigan J., Moran D., Rounsevell M.D.A. (2017) Losses, inefficiencies and waste in the global food system. Agric Syst 153: 190-200.

Allen A. (2003) Environmental planning and management of the peri-urban interface: perspectives on an emerging field. Environment\&Urbanization 15: 135-147.

Arushanyan Y., Björklund A., Eriksson O., Finnveden G., Ljunggren Söderman M., Sundqvist J.-O., Stenmarck Å. (2017) Environmental Assessment of Possible Future Waste Management Scenarios. Energies 10.

Ayele Z., Peacock C. (2003) Improving access to and consumption of animal source foods in rural households: the experiences of a women-focused goat development program in the highlands of Ethiopia. J Nutr 133: 3981S-3986S.

Bai Z., Lu J., Zhao H., Velthof G.L., Oenema O., Chadwick D., Williams J.R., Jin S., Liu H., Wang M., Strokal M., Kroeze C., Hu C., Ma L. (2018) Designing Vulnerable Zones of Nitrogen and Phosphorus Transfers To Control Water Pollution in China. Environ Sci Technol 52: 8987-8988.

Bernal M.P. (2017) Grand Challenges in Waste Management in Agroecosystems. Frontiers in Sustainable Food Systems 1.

Caria S. (2019) "Industrialization on a Knife's Edge Productivity, Labor Costs and the Rise of Manufacturing in Ethiopia. Policy Research Working Paper 8980, Worldbank.."

Chen Y., Camps-Arbestain M., Shen Q., Singh B., Cayuela M.L. (2018) The long-term role of organic amendments in building soil nutrient fertility: a meta-analysis and review. Nutrient Cycling in Agroecosystems 111: 103-125.

Clark M., Tilman D. (2017) Comparative analysis of environmental impacts of agricultural production systems, agricultural input efficiency, and food choice. Environmental Research Letters 12. 
Cochrane L., Bekele Y.W. (2018). Average crop yield (2001-2017) in Ethiopia: Trends at national, regional and zonal levels. Data Brief 16: 1025-1033.

Comanita E.-D., Hlihor R.M., Ghinea C., Gavrilescu M. (2016) Occurrence of Plastic Waste in the Environment: Ecological and Health Risks. Environmental Engineering and Management Journal 15: 675-685.

Croppenstedt A., Demeke M., Meschi M.M. (2003) Technology Adoption in the Presence of Constraints: the Case of Fertilizer Demand in Ethiopia. Review of Development Economics 7: 58-70.

de Bruyn J., Ferguson E., Allman-Farinelli M., Darnton-Hill I., Maulaga W., Msuya J., Alders R. (2016) Food composition tables in resource-poor settings: exploring current limitations and opportunities, with a focus on animal-source foods in sub-Saharan Africa. Br J Nutr, 1-11.

de Zeeuw H., van Veenhuizen R., Dubbeling M. (2011) The role of urban agriculture in building resilient cities in developing countries. The Journal of Agricultural Science 149: 153-163.

Di Falco S., Veronesi M., Yesuf M. (2011) Does Adaptation to Climate Change Provide Food Security? A Micro-Perspective from Ethiopia. American Journal of Agricultural Economics 93: 829-846.

Diacono M., Persiani A., Testani E., Montemurro F., Ciaccia C. (2019) Recycling agricultural wastes and by-products in Organic Farming: Biofertilizer production, yield performance and carbon footprint analysis. Sustainability 11.

Elias E., Okoth P. F., Smaling E.M.A. (2019) Explaining bread wheat (Triticum aestivum) yield differences by soil properties and fertilizer rates in the highlands of Ethiopia. Geoderma 339: 126-133.

Enahoro D., Lannerstad M., Pfeifer C., Dominguez-Salas P. (2018) Contributions of livestockderived foods to nutrient supply under changing demand in low- and middle-income countries. Global Food Security 19: 1-10.

FAO (2011). The place of urban and peri-urban agriculture (upa) in national food security programmes.

Ghosh P.R., Fawcett D., Sharma S.B., Poinern G.E. (2016) Progress towards sustainable utilization and management of food wastes in the Global Economy. Int J Food Sci 2016: 3563478.

Hijbeek R., ten Berge H.F.M., Whitmore A.P., Barkusky D., Schröder J.J., van Ittersum M.K. (2018) Nitrogen fertiliser replacement values for organic amendments appear to increase with $\mathrm{N}$ application rates. Nutr Cycl Agroecosyst 110: 105-115.

Holden S.T. (2019) Economics of Farm Input Subsidies in Africa. 11: 501-522.

Horrocks A., Curtin D., Tregurtha C., Meenken E. (2016) Municipal Compost as a Nutrient Source for Organic Crop Production in New Zealand. Agronomy 6.

Hou Y., Velthof G.L., Lesschen J. P., Staritsky I.G., Oenema O. (2017) Nutrient Recovery and Emissions of Ammonia, Nitrous Oxide, and Methane from Animal Manure in Europe: Effects of Manure Treatment Technologies. Environ Sci Technol 51: 375-383.

Jagisso Y., Aune J., Angassa A. (2019) Unlocking the agricultural potential of manure in agropastoral Systems: traditional beliefs hindering its use in southern Ethiopia. Agriculture 9. 
Jara-Samaniego J., Perez-Murcia M.D., Bustamante M.A., Paredes C., Perez-Espinosa A., Gavilanes-Teran I., Lopez M., Marhuenda-Egea F.C., Brito H., Moral R. (2017) Development of organic fertilizers from food market waste and urban gardening by composting in Ecuador. PLoS One 12: e0181621.

Komakech A. (2014) Urban waste management and the environmental impact of organic waste treatment systems in Kampala, Swedish University of Agricultural Sciences, Uppsala and Makerere University, Kampala.

Krause A., Rotter V. (2018) Recycling Improves Soil Fertility Management in Smallholdings in Tanzania. Agriculture 8.

Kwasi A.A. (2010). Urban and Peri-Urban Agriculture in Developing Countries Studied using Remote Sensing and In Situ Methods. Remote Sensing 2: 497-513.

Lee-Smith D. (2010). Cities feeding people: an update on urban agriculture in equatorial Africa. Environment and Urbanization 22: 483-499.

Lonnie M., Hooker E., Brunstrom J.M., Corfe B.M., Green M.A., Watson A.W., Williams E.A., Stevenson E.J., Penson S., Johnstone A.M. (2018) Protein for Life: Review of Optimal Protein Intake, Sustainable Dietary Sources and the Effect on Appetite in Ageing Adults. Nutrients 10.

Lupindu A.M. (2017) Public Health Aspect of Manure Management in Urban and Peri-Urban Livestock Farming in Developing Countries. In "Livestock Science".

Ma L., Ma W.Q., Velthof G.L., Wang F.H., Qin W., Zhang F.S., Oenema O. (2010) Modeling nutrient flows in the food chain of China. J Environ Qual 39: 1279-1289.

Ma L., Zhang W.F., Ma W.Q., Velthof G.L., Oenema O., Zhang F.S. (2013) An analysis of developments and challenges in nutrient management in china. J Environ Qual 42: 951961.

Makita K., Fevre E.M., Waiswa C., Bronsvoort M.D., Eisler M.C., Welburn S.C. (2010) Population-dynamics focussed rapid rural mapping and characterisation of the periurban interface of Kampala, Uganda. Land use policy 27: 888-897.

Manyi-Loh C.E., Mamphweli S.N., Meyer E.L., Makaka G., Simon M., Okoh A. I. (2016) An Overview of the Control of Bacterial Pathogens in Cattle Manure. Int J Environ Res Public Health 13.

Marshall R.E., Farahbakhsh K. (2013) Systems approaches to integrated solid waste management in developing countries. Waste Manag 33: 988-1003.

Martens W., Bohm R. (2009) Overview of the ability of different treatment methods for liquid and solid manure to inactivate pathogens. Bioresour Technol 100: 5374-5378.

Mulugeta M. (2013) The Need for Policy Framework for Urban/Peri-Urban Agriculture in Ethiopia: A Reflection. EJOSSAH 9: 79-109.

Nigussie A., Kuyper T., de Neergaard A. (2015) Agricultural waste utilisation strategies and demand for urban waste compost: Evidence from smallholder farmers in Ethiopia. Waste Manag 44: 82-93.

Opitz I., Berges R., Piorr A., Krikser T. (2015) Contributing to food security in urban areas: differences between urban agriculture and peri-urban agriculture in the Global North. Agriculture and Human Values 33: 341-358.

Robinson T.P., Thornton P.K., Franceschini G., Kruska R.L., Chiozza F., Notenbaert A., Cecchi G., Herrero M., Epprecht M., Fritz S., You L., Conchedda G., See L. (2011) 
Global livestock production systems. Rome, Food and Agriculture Organization of the United Nations (FAO) and International Livestock Research Institute(ILRI), 152 pp.

Rodd A.V., Warman P.R., Hicklenton P., Webb K. (2002) Comparison of N fertilizer, sourceseparated municipal solid waste compost and semi-solid beef manure on the nutrient concentration in boot-stage barley and wheat tissue. Can. J. Soil Sci. 82: 33-43.

Roessler R., Mpouam S., Muchemwa T., Schlecht E. (2016) Emerging Development Pathways of Urban Livestock Production in Rapidly Growing West Africa Cities. Sustainability 8.

Rufino M.C., Rowe E.C., Delve R.J., Giller K.E. (2006) Nitrogen cycling efficiencies through resource-poor African crop-livestock systems. Agriculture, Ecosystems \& Environment 112: 261-282.

Sassenrath G.F., Schneider J.M., Gaj R., Grzebisz W., Halloran J.M. (2013) Nitrogen balance as an indicator of environmental impact: Toward sustainable agricultural production. Renewable Agriculture and Food Systems 28: 276-289.

Satterthwaite D. (2017) The impact of urban development on risk in sub-Saharan Africa's cities with a focus on small and intermediate urban centres. International Journal of Disaster Risk Reduction 26: 16-23.

Schonfeldt H.C., Hall N.G. (2012) Dietary protein quality and malnutrition in Africa. Br J Nutr 108(2): S69-S76.

Snijders P., Davies O., Bram W., Louis G., Joshua Z., Peter E., Kebebe E., Muktar A., van Keulen H. (2009) "Cattle manure management in East Africa: Review of manure quality and nutrient losses and scenarios for cattle and manure management," Rep. No. 258.

Spangberg J., Tidaker P., Jonsson H. (2014) Environmental impact of recycling nutrients in human excreta to agriculture compared with enhanced wastewater treatment. Sci Total Environ 493: 209-219.

Swain B.B., Teufel N. (2017) The impact of urbanisation on crop-livestock farming system: a comparative case study of India and Bangladesh. Journal of Social and Economic Development 19: 161-180.

Tadesse S.T., Oenema O., van Beek C.,Ocho F. L. (2018) Diversity and nutrient balances of urban and peri-urban farms in Ethiopia. Nutrient Cycling in Agroecosystems 111: 118.

Tadesse S.T., Oenema O., van Beek C., Ocho F.L. (2019) Nitrogen allocation and recycling in peri-urban mixed crop-livestock farms in Ethiopia. Nutrient Cycling in Agroecosystems 115: 281-294.

Tadesse S.T., Oenema O., van Beek C., Ocho F.L. (2021) Manure recycling from urban livestock farms for closing the urban-rural nutrient loops. Nutrient Cycling in Agroecosystems 119: 51-67.

Taffesse A.S., Dorosh P., Asrat S. (2011) Crop Production in Ethiopia: Regional Patterns and Trends. In "Development Strategy and Governance Division, International Food Policy Research Institute, Ethiopia Strategy Support Program II, Ethiopia", Vol. ESSP II Working Paper No. 0016. IFPRI, Addis Ababa, Ethiopia.

Tesfaye K., van Ittersum M.K., Wiebe K., Boogaard H., Radeny M., Solomon D. (2018) Can Ethiopia feed itself by 2050? Estimating cereal self-sufficiency to 2050. CCAFS Policy 
Brief no. 12. Wageningen, the Netherlands: CGIAR Research Program on Climate Change, Agriculture and Food Security (CCAFS). Available online at: www.ccafs.cgiar.org.

Teshome M. (2014) Population Growth and Cultivated Land in Rural Ethiopia: Land Use Dynamics, Access, Farm Size, and Fragmentation. Resources and Environment 4: 148161.

Thornton P.K. (2010) Livestock production: recent trends, future prospects. Philos Trans R Soc Lond B Biol Sci 365: 2853-2867.

Tilahun A.I., Tamado T. (2019) Growth, yield component and yield response of durum wheat (Triticum turgidum L. var. Durum) to blended NPS fertilizer supplemented with N rates at Arsi Negelle, Central Ethiopia. African Journal of Plant Science 13: 9-20.

Tiquia S.M., Richard T.L., Honeyman M.S. (2002) Carbon, nutrient, and mass loss during composting. Nutrient Cycling in Agroecosystems 62: 15-24.

UN (2019) "World Urbanization Prospects: The 2018 Revision (ST/ESA/SER.A/420)," Rep. No. 420. United Nations, New York.

van Beek C.L., Elias E., Yihenew G.S., Heesmans H., Tsegaye A., Feyisa H., Tolla M., Melmuye M., Gebremeskel Y., Mengist S. (2016) Soil nutrient balances under diverse agro-ecological settings in Ethiopia. Nutrient Cycling in Agroecosystems 106: 257274.

van Vuuren D.P., Kok M., Lucas P.L., Prins A.G., Alkemade R., van den Berg M., Bouwman L., van der Esch S., Jeuken M., Kram T., Stehfest E. (2015) Pathways to achieve a set of ambitious global sustainability objectives by 2050: Explorations using the IMAGE integrated assessment model. Technological Forecasting \& Social Change 98: 303-323.

Verma R., Vinoda K.S., Papireddy M., Gowda A.N.S. (2016) Toxic Pollutants from Plastic Waste- A Review. Procedia Environmental Sciences 35: 701-708.

Wang M., Ma L., Strokal M., Chu Y., Kroeze C. (2018) Exploring nutrient management options to increase nitrogen and phosphorus use efficiencies in food production of China. Agricultural Systems 163: 58-72.

Webb J., Sørensen P., Velthof G., Amon B., Pinto M., Rodhe L., Salomon E., Hutchings N., Burczyk P., Reid J. (2013) An Assessment of the Variation of Manure Nitrogen Efficiency throughout Europe and an Appraisal of Means to Increase Manure-N Efficiency. pp. 371-442.

Wei Y., Zhao Y., Xi B., Wei Z., Li X., Cao Z. (2015) Changes in phosphorus fractions during organic wastes composting from different sources. Bioresour Technol 189: 349-356.

Wilson R.T. (2018). Domestic Livestock in African Cities: Production, Problems and Prospects. Open Urban Studies and Demography Journal 4: 1-14.

Withers P.J., van Dijk K.C., Neset T.S., Nesme T., Oenema O., Rubaek G.H., Schoumans O.F., Smit B., Pellerin S. (2015) Stewardship to tackle global phosphorus inefficiency: The case of Europe. Ambio 44 (2): S193-S206.

Wolka K., Melaku B. (2015) Exploring selected plant nutrient in compost prepared from food waste and cattle manure and its effect on soil properties and maize yield at Wondo Genet, Ethiopia. Environmental Systems Research 4. 
Workicho A., Belachew T., Feyissa G.T., Wondafrash B., Lachat C., Verstraeten R., Kolsteren P. (2016) Household dietary diversity and Animal Source food consumption in Ethiopia: evidence from the 2011 Welfare Monitoring Survey. BMC Public Health 16: 1192.

Yu C., Xiao Y., Ni S. (2017) Changing patterns of urban-rural nutrient flows in China: driving forces and options. Science Bulletin 62: 83-91.

Zhang X., Fang Q., Zhang T., Ma W., Velthof G.L., Hou Y., Oenema O., Zhang F. (2020) Benefits and trade-offs of replacing synthetic fertilizers by animal manures in crop production in China: A meta-analysis. Glob Chang Biol 26: 888-900.

Zhu Y.G., Reid B.J., Meharg A.A., Banwart S.A., Fu B.J. (2017) Optimizing Peri-URban Ecosystems (PURE) to re-couple urban-rural symbiosis. Sci Total Environ 586: 10851090.

Zoboli O., Zessner M., Rechberger H. (2016) Supporting phosphorus management in Austria: Potential, priorities and limitations. Sci Total Environ 565: 313-323. 
CHAPTER 6

General Discussion 


\subsection{Introduction}

Changes in population, urbanization, diets, agricultural practices and waste recycling are main drivers of nitrogen $(\mathrm{N})$ and phosphorus $(\mathrm{P})$ flows, and of their impacts on the environment. Urbanization is altering the ratio of food production to food demand in both urban and rural areas. With more people living in cities, more agricultural products and associated nutrients leave the countryside and flow to the urban environment. The net transport of nutrients in food and feed from areas of production to areas of consumption is aggravating the depletion of nutrients in areas of food production and contributes to accumulation of nutrient in urban areas, where increasing amounts of food are consumed. However, the regional diversity in urbanization and associated changes in nutrient flows is large.

Ethiopia is one of the rapidly growing economies, and the second most populous country next to Nigeria in Africa. The urban population increased by $8.9 \%$ between 1984 and 2007 (Dorosh and Schmidt, 2010). The increase in urban food demand paved a way for farming in and around cities called Urban and Peri-urban Agriculture (UPA) (Bon et al., 2010; Cofie et al., 2003; Thornton, 2010). UPA provides an opportunity for improving food supply and socioeconomic sustainability of urban areas (Orsini et al., 2013). It involves mixed and specialized livestock, vegetables and field crops production. UPA is important as it contributes to the livelihoods of urban dwellers and supplements the mainstream food production (Makita et al., 2010). The popularity of UPA also relates to its potential to adapt to local conditions, to increase its level of production and to provide targeted services to the urban residents, while its possible effects on the environment and human health are largely neglected or unknown (Nugent, 2001). The diversity and socioeconomic and environmental performances of UPA in Ethiopia are largely unknown, which make it difficult to articulate strategies for realizing its potentials (Chatterjee et al., 2015).

The general objective of my thesis research is to increase the insights in the diversity, characteristics and performances of UPA farms in Ethiopia, and to examine the potentials of increased recycling of urban livestock manure and waste nutrients, to close the urban-rural nutrient loops (Chapter 1).

The purpose of this general discussion chapter is to give an overview of the main findings of my research and to integrate these findings within the context of the global scientific UPA literature.

\subsection{Main findings}

Livestock manures and household wastes are little recycled and utilized in crop production in urban and peri-urban areas, as nutrient resource. This poor recycling is partly related to competing uses (manure is also used as biofuel and for construction of houses), partly to cultural barriers (in the case of household wastes), and partly also to lack of knowledge, technology and incentives. This was a main finding during my first survey of UPA farms in 
three cities in Ethiopia; there was essentially no exchange of manure and waste nutrients between farms with excess to farms with shortages of nutrients (Chapter 2).

Another main finding was the huge diversity in UPA, which disproved a traditional perception that livestock, vegetable and crop production are carried out by separate households. A systematic inventory and classification of UPA farms was made, and 6 UPA farm types were identified and characterized on the basis of their primary farming objectives, resource endowments, use of agricultural waste for soil fertility management, nutrient balances and income levels. This classification and characterization increased our understanding on agronomic, socioeconomic and environmental performances of UPA systems.

Commercial livestock farms in the urban and peri-urban areas had large nutrient surpluses

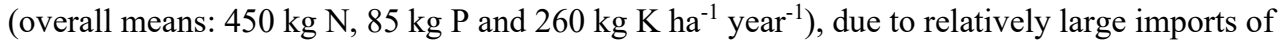
nutrients in animal feed and little export of nutrients in animal produce, including manure. In contrast, field crop farms in the same zone as the livestock farms had $\mathrm{N}$ and $\mathrm{K}$ deficits (overall means: $30 \mathrm{~kg} \mathrm{~N}$ and $17 \mathrm{~kg} \mathrm{~K} \mathrm{ha}^{-1}$ year $^{-1}$ ), but $\mathrm{P}$ surpluses (Chapter 2). Ideally, the untapped manures of commercial livestock farms should have been transported to the subsistence field crop farms, where there is high demand of nutrients, but this exchange did not happen.

The study of Finn (1980) was one of the first studies that developed the cycling index 'CI', defined as the fraction of total system throughflow that is cycled based on a quantitative nutrient input-output flow analysis. We introduced the crop-livestock ratio (CLS) as an indicator for the analysis of $\mathrm{N}$ flows and allocation to crop and livestock compartments within mixed crop-livestock farms, one of the six farm types identified in Chapter 2. The CLS indicator helped to understand the relative allocation of the external $\mathrm{N}$ inputs to the soil/crop and livestock compartments in mixed farms. Further, the CLS helped us to characterize mixed crop-livestock farms in crop-oriented mixed farms and livestock-oriented mixed farms. These two farm orientations differed not only in $\mathrm{N}$ allocation, but also in partial $\mathrm{N}$ balance, $\mathrm{N}$ use efficiency, and net farm income. Livestock-oriented mixed farms allocated 4-5 times higher $\mathrm{N}$ inputs to the livestock component, had 7 times higher $\mathrm{N}$ surpluses and 2-4 times higher net farm income than crop-oriented mixed farms (Chapter 3). This showed the economic importance of the livestock component relative to the crop component in mixed farms, which reflects the increasing demand of animal origin food in the rapidly growing cities of Ethiopia. Thornton (2010) reported that income growth and urbanization are main drivers of changes in the demand of animal products.

In Chapter 4, I estimated the potentials of recycling urban livestock manures based on data from farm surveys, statistics, literature data and model calculations. As much as $0.5-2.6 \mathrm{Gg} \mathrm{N}$, 0.2-0.8 Gg P and 0.9-3.7 Gg K could have been collected in manure from urban livestock farms in Addis Ababa, and recycled in cropland in 2015. This increased recycling may increase food production, save fertilizer costs, and reduce environmental pollution. 
I explored two manure allocation strategies and found that balanced $\mathrm{P}$ fertilization allowed greater precision in matching the nutrient supply to nutrient demand, and was associated with greater manure transport from urban areas to rural areas. Shrestha et al. (2020) also reported that application of compost based on crop $\mathrm{P}$ demand resulted in more precision of matching crop nutrient demand than application of compost based on crop $\mathrm{N}$ demand. Though the potential is large, we observed during the farm surveys a lack of knowledge, advisory services, and policy incentives to make the exchange of manure between livestock farms and crop farms happen easily. There are also weak institutional structures and cultural barriers preventing the maximization of the benefits of manure recycling (Chapter 4).

In Chapter 5, I explored the effects of possible future development scenarios (population growth, increased urbanization, UPA intensification, and improved technology) on foodprotein self-sufficiency, manure $\mathrm{N}$ recycling and $\mathrm{N}$ balances in Jimma for the period 20152050. This is the first scenario analysis at regional level in Ethiopia. The emphasis in recycling livestock manures and wastes was on $\mathrm{N}$, because the availability of $\mathrm{N}$ limits crop production in the rural areas most and the losses of $\mathrm{N}$ to the wider environment has significant human health and ecological impacts. I also included some cost benefit analysis of manure recycling.

In a scenario with increased urbanization and associated UPA developments, the amounts of manure and waste $\mathrm{N}$ produced in urban and peri-urban areas increased fast over time. In the business-as-usual scenario, the animal-sourced protein intake per capita was set at low level, concurrent with estimates for SSA. Small increases in the animal-sourced protein intake per capita had a huge effect on the amount of manure and waste nutrients produced in the urban and peri-urban environments. In all scenarios, crop-protein production has to increase by more than 3\% per year between 2015 and 2050 to satisfy the demand of crop protein for both people and livestock. Further, this scenario analysis indicated that manure from UPA livestock farming was the main source of organic waste in the urban environment, and is the targeted resource for nutrient recycling. Total manure $\mathrm{N}$ production in the urban and peri-urban areas will likely increase by a factor of 3 to 10 during the next three decades (Figure 5.1), as a result of population growth, urbanization and UPA intensification.

We found that reducing population growth in urban areas from $5 \%$ to $2.5 \%$ and doubling crop and animal productivity will contribute to achieve self-sufficiency of crop protein production in the area. Doubling animal productivity (doubling the feed protein-N conversion) will halve manure $\mathrm{N}$ production, and targeted technological measures may significantly reduce $\mathrm{N}$ losses from manure storages and save fertilizer costs. Increased productivity and technological measures combined may greatly contribute to a reduced growth of $\mathrm{N}$ surpluses over time (Figure 5.5). Improvements in productivity and $\mathrm{N}$ use efficiency of UPA livestock farming will also contribute to food self-sufficiency and environmental sustainability. Ma et al. (2013a) also reported that packages of integrated nutrient management measures reduced the losses of nutrients and greatly increased $\mathrm{N}$ and $\mathrm{P}$ use efficiencies. The poor recycling efficiency in scenarios without improved technology is consistent with the results of a literature review, which indicated that $\mathrm{N}$ losses from manure storages in Africa roughly range between 40 and $70 \%$ of the $\mathrm{N}$ contained in the manures, depending on manure quality and storage conditions 
(Snijders et al., 2009). Beside the poor manure quality and storage conditions, there are cultural, educational and institutional barriers for collecting and recycling manures and wastes from urban areas into rural areas of Ethiopia (Chapter 2; Marshall and Farahbakhsh (2013)).

Results of field experiments verified the benefits of recycling composted manures of urban livestock farms and kitchen wastes of urban households as soil amendments for crop production in peri-urban areas (Chapter 5). Composts derived from manures and kitchen wastes increased wheat grain and straw yields, the N, P and K contents in biomass and reversed the negative $\mathrm{N}$, $\mathrm{P}$ and $\mathrm{K}$ balances to positive balances.

\subsection{Assessing and improving the sustainability of UPA farms}

The role of UPA in restoring nutrient recycling into the food systems is receiving increased attention (Wielemaker et al., 2019). This role differs between the different UPA farm types and differently affects the economic, environmental and social sustainability goals.

\subsubsection{Economic sustainability}

Economic sustainability is a key component of agricultural sustainability, as the environmental and social sustainability are dependent on it (Savickiene and Miceikiene, 2018). For long term sustainability, farm systems should be economically viable. Economic sustainability is mainly measured through profitability via comparing revenue and cost, proxied by income variables such as farm income (Latruffe et al., 2016). In this regard, commercial livestock farms generated the highest net farm income (Figure 6.1) signifying their economic sustainability. Abdulkadir et al. (2013) also reported that commercial livestock keeping was economically more profitable than the other farm types. As a result, UPA farms are becoming more and more specialized in livestock production in Addis Ababa, Adama and Jimma urban areas (Chapter 2). Ryan et al. (2016) also reported that dairy farms are economically most sustainable across the Irish farm systems. In contrast, the subsistence field crop farms generated low farm income (Figure 6.1) and appeared economically unsustainable (Latruffe et al., 2016). The urban subsistence field crop farms are rather similar to the rural subsistence field crop farms (Nigussie et al., 2015; van Beek et al., 2016). 


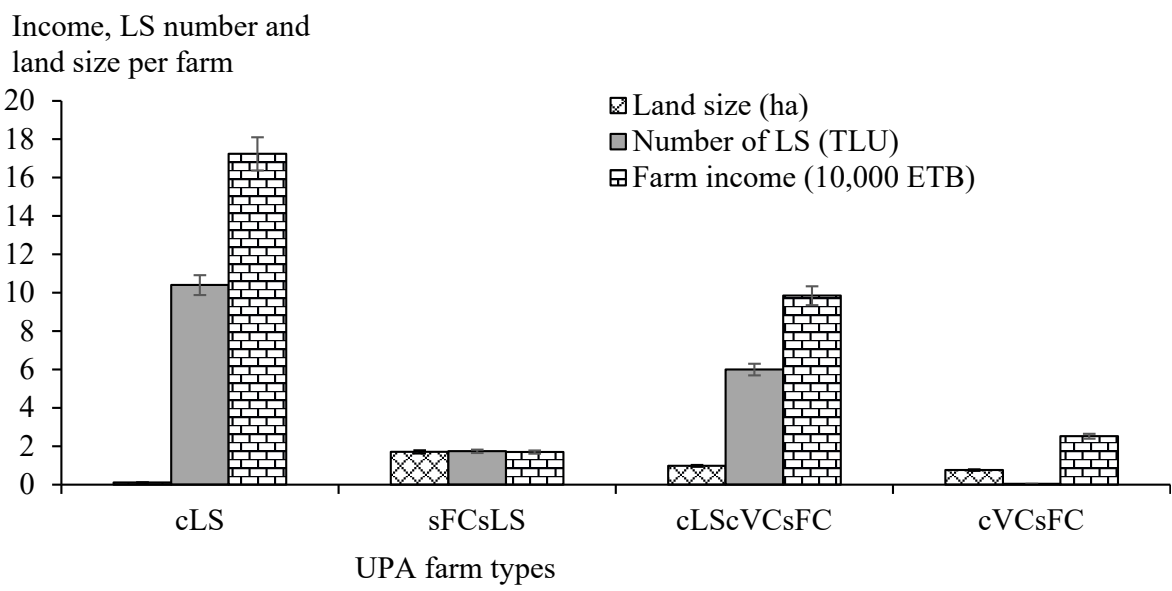

Figure 6.1 The relation between mean values of farm income (10,000 ETB), number of livestock (TLU) and land size (ha) per farm for four typologies of UPA farms: cLS $=$ commercial livestock, sFCsLS $=$ subsistence field crop and subsistence livestock, $\mathrm{cLScVCsFC}=$ commercial livestock, commercial vegetable crop and subsistence field crop and $\mathrm{cVCsFC}=$ commercial vegetable crop and subsistence field crop farms, identified at Addis Ababa (See Chapter 2, Table 2.5).

For improving the economic sustainability of subsistence field crop farms, farm productivity and product prices should be increased through improving the access of farmers to agricultural inputs, reducing the high cost of inputs through subsidies and linking the subsistence field crop farms with commercial livestock farms for efficient manure nutrient recycling (Tadesse et al., 2018). Through the envisaged recycling of manure from urban livestock farms to crop farms, 75-300 million ETB spent for purchase of inorganic fertilizers can be saved per year by Addis Ababa crop farms. This signifies the contribution of manure recycling to the economic sustainability of crop farming and in the realization of the circular economy in the food systems. The urban manure recycling will also create alternative job opportunities as off-farm activities in the urban areas or as middle men for transporting manures from livestock farms to crop farms.

\subsubsection{Environmental sustainability}

For assessing the environmental sustainability of farming systems, nutrient balances are considered useful indicators (Abdulkadir et al., 2013). Both, policy makers and farmers may use the nutrient balance as a tool to gain insight on the environmental impact of agricultural practices (van Leeuwen et al., 2019). As shown in Chapter 2, the differences between the UPA farm types in soil fertility management and nutrient balances highlighted the differences in environmental sustainability between the farm types. The mean positive balances of $450 \mathrm{~kg} \mathrm{~N}$, $85 \mathrm{~kg} \mathrm{P}$ and $260 \mathrm{~kg} \mathrm{~K} \mathrm{ha}^{-1}$ year $^{-1}$ in UPA livestock farms and the mean negative balances of $30 \mathrm{~kg} \mathrm{~N}$ and $-17 \mathrm{~kg} \mathrm{~K} \mathrm{ha}^{-1}$ year $^{-1}$ in UPA crop farms suggest that both farm systems are environmentally unsustainable. Similarly, Abdulkadir et al. (2013) reported positive balances of $563 \mathrm{~kg} \mathrm{~N}, 411 \mathrm{~kg} \mathrm{P}$ and $646 \mathrm{~kg} \mathrm{~K} \mathrm{ha}^{-1}$ year $^{-1}$ for UPA livestock farms. However, they 
reported also positive $\mathrm{N}$ and $\mathrm{P}$ balances in urban and peri-urban vegetable and crop production systems, which is in contrast to the negative $\mathrm{N}$ and $\mathrm{K}$ balances in the UPA crop farms we studied. This could be attributed to differences in the availability of subsidized fertilizers and other nutrient resources. Abdulkadir et al. (2013) reported that nutrient inputs to vegetables and crops were mainly through waste water sources; manure contributed $6 \% \mathrm{~N}, 18 \% \mathrm{P}$ and $5 \% \mathrm{~K}$, mineral fertilizer contributed $12 \% \mathrm{~N}, 14 \% \mathrm{P}$ and $7 \% \mathrm{~K}$, while irrigation water contributed $82 \%$ $\mathrm{N}, 68 \% \mathrm{P}$ and $88 \% \mathrm{~K}$ to the total nutrient inputs.

In my study area, manures were partly used for biofuel and construction, while crop residues were used as animal feed. Competing alternative uses is a major factor explaining the low use of crop residues and manures in soil fertility management of croplands. As shown in Chapter 2 , more than $50 \%$ of the UPA farms didn't use manures and household wastes for soil fertility management, for the following reasons. First, in subsistence crop and vegetable farms, the options to use manures and wastes for soil fertility management were limited due to low levels of crop production and high biomass demand for feed and fuel. Second, close to the urban centers, livestock farms have no land; therefore, they simply dumped animal manure in ditches and surroundings or left it unmanaged on the ground, while some dung was used as biofuel. Nigussie et al. (2015) also reported that a large quantity of waste was dumped in landfills in Ethiopia.

The competition between uses (feed, energy, soil fertility) for crop residues and manures has been reported also for other countries (Baudron et al., 2014; Jaleta et al., 2015; Valbuena et al., 2015). The challenges are how to fulfil the demand for both animal feed and household fuel on the one hand and soil on the other hand. Biomass fuel makes about $90 \%$ of the total energy demand, and $85 \%$ of cooking fuel consumed by urban households in Ethiopia (Negash et al., 2017). Yet, a large fraction of manures and household wastes in urban areas is simply disregarded, while there is a need for organic matter and nutrients input into cropland. It is essential that enabling policies and institutions are developed for increasing the exchange of manures and wastes between urban livestock farms and crop farms in urban, peri-urban and rural areas.

A high livestock density in livestock farms is associated with large nutrient surpluses and low nutrient use efficiencies, because the import of nutrients via animal feed was much larger than the export of nutrients via animal produce, including manure. Saam et al. (2005) also reported that imports of feed, fertilizer and other nutrient sources decreases the nutrient use efficiency of the farm. Actually, an increasing reliance of farms on imported feed is related to a small land base. On the other hand, negative $\mathrm{N}$ and $\mathrm{K}$ balances in crop farms are the result of a relatively large nutrient exports, because crop residues are also harvested, while nutrient inputs are very small. The high nutrient use efficiency in these crops farms is indicative for the low nutrient input relative to the nutrient output with the harvested crops. Actually, this goes with the 'law of diminishing returns' typical to all biological systems, where the highest nutrient use efficiency often is obtained at the lowest levels of nutrient inputs (Roberts, 2008). 
As indicated in Chapter 4, the coupling of crop farms with livestock farms is the way forward to utilize both manures and crop residues, and to increase the economic and environmental sustainability of the farms (Table 6.1). Through the envisaged improved manure recycling losses of 0.5-2.6 Gg N, 0.2-0.8 Gg P and 0.9-3.7 Gg K per year can be minimized and saved from polluting the urban environment of Addis Ababa (Chapter 4). Zhang et al. (2020a) stated that the balance between efficient resource uses and beneficial environmental consequences are vital for sustained agricultural development globally. Kumar et al. (2019) indicated that integrated crop and livestock systems positively affects crop production by improving soil health, increasing economic benefits, and reducing economic risks. Garrett et al. (2017a) reported that reintegrating crop and livestock systems has the potential to address several ecological and social objectives of agriculture: producing high yields, reducing pollution and external fertilizer use and biocide dependence, reducing climate vulnerability, promoting more diverse on-farm habitat, and reducing risk to market fluctuations. The 'global network of elements' highlighted the positive role that UPA may have in the local ecosystems of cities (Sanyé-Mengual et al., 2018). They consider the recycling of organic waste as one of the most relevant elements of UPA. This idyllic picture of UPA contrasts with the UPA farms studied in Ethiopia. Indeed, enabling policies and institutions are needed to fully cash the potentials of UPA and the coupling of crop and livestock production systems in enhancing resource use efficiency and nutrient recycling.

Table 6.1 Calculated changes in nutrient (N, P and K) flows, balances and use efficiencies of farms after manure recycling from urban livestock (LS) farms to the urban, peri-urban and rural crop farms of Addis Ababa city.

\begin{tabular}{|c|c|c|c|c|c|c|c|c|}
\hline \multirow{4}{*}{ Nutrient flows } & \multicolumn{8}{|c|}{ Recycling (from-to) } \\
\hline & \multirow{2}{*}{\multicolumn{2}{|c|}{$\begin{array}{l}\text { From LS farms } \\
\text { of urban areas }\end{array}$}} & \multicolumn{6}{|c|}{ To Crop farms of } \\
\hline & & & \multicolumn{2}{|c|}{ Urban areas } & \multicolumn{2}{|c|}{ Peri-urban areas } & \multicolumn{2}{|c|}{ Rural areas } \\
\hline & Before & After & Before & After & Before & After & Before & After \\
\hline Recycled N & 0 & 103 & 0 & 103 & 0 & 103 & 0 & 103 \\
\hline $\mathrm{N}$ input & 534 & 534 & 87 & 190 & 105 & 208 & 80 & 183 \\
\hline $\mathrm{N}$ output & 191 & 294 & 168 & 168 & 148 & 148 & 129 & 129 \\
\hline$N$ balance & 343 & 204 & -81 & 22 & -43 & 60 & -49 & 54 \\
\hline Nuse efficiency & 36 & 55 & 193 & 88 & 141 & 71 & 161 & 70 \\
\hline Recycled P & 0 & 32 & 0 & 32 & 0 & 32 & 0 & 32 \\
\hline$P$ input & 82 & 82 & 23 & 55 & 30 & 62 & 17 & 49 \\
\hline P output & 29 & 61 & 17 & 17 & 6 & 6 & 3 & 3 \\
\hline$P$ balance & 53 & 21 & 6 & 38 & 24 & 56 & 14 & 46 \\
\hline$P$ use efficiency & 35 & 74 & 74 & 31 & 20 & 10 & 18 & 6 \\
\hline Recycled K & 0 & 94 & 0 & 94 & 0 & 94 & 0 & 94 \\
\hline $\mathrm{K}$ input & 280 & 280 & 24 & 118 & 22 & 116 & 6 & 100 \\
\hline K output & 93 & 187 & 103 & 103 & 31 & 31 & 17 & 17 \\
\hline$K$ balance & 187 & 93 & -79 & 15 & -9 & 85 & -11 & 83 \\
\hline K use efficiency & 33 & 67 & 429 & 87 & 141 & 27 & 283 & 17 \\
\hline
\end{tabular}

Note: Changes in nutrient outputs of livestock farms, in inputs of crop farms, in balances and use efficiencies of both farm types indicated in italic are recalculated based on data presented in Chapter 4, Table 4.3 for 4 farm types: urban livestock farms, urban, peri-urban and rural crop farms for the 2016 monitoring year. For the recycling of surplus N, P and K of urban livestock farms the lowest recovery fraction of 0.3 for $\mathrm{N}, 0.6$ for $\mathrm{P}$ and 0.5 for $\mathrm{K}$ was assumed (See text in Chapter 4).

The results presented in Chapters 2, 3, 4 and 5 also highlighted the need for government policies and incentives aimed at sustainable intensification of UPA focusing on the exchange and recycling of manures and feeds between livestock farms and crop farms and within mixed crop 
livestock farms. Garrett et al. (2017a) also suggested policy incentives for integrating crop and livestock systems such as (i) strengthening environmental policies (and enforcement) that punish nutrient runoff and reward nutrient recycling; (ii) reducing food safety restrictions on the integration of animals and manure in cropland; and (iii) strengthening research and development for integrated crop livestock systems. Further, reintegrating crop and livestock systems at field and farm levels may contribute to improving soil quality, reducing water and air pollution, while maintaining high yields and reducing risk of crop failure (Garrett et al., 2017a; Garrett et al., 2017b). However, the challenge here is that some farms specialize in livestock production while others in crop production, as specialized animal production and crop production systems often produce at lower costs than mixed systems. Large specialized and intensive systems can often comply also much easier with the requirements of the food processing industries and suppliers, and thereby get more easy access to new information and technologies.

Junge et al. (2020) stated that UPA may contribute to creating more sustainable and climatefriendly cities as UPA has the capacity to integrate resource streams such as water, waste and energy and thereby may contribute to improving the quality of life in urban areas. However, the challenges facing urban farms are hindering them from providing the ecosystem services at their full potential. For instance, high cost of inputs in crop production and high cost of feed in livestock production are major constraints of UPA across the three Ethiopian cities (Tadesse et al., 2018).

\subsubsection{Social sustainability}

Social sustainability aspects of UPA (i.e., improved access to affordable food and increased farm income and employment) are among the most relevant benefits of UPA (Sanyé-Mengual et al., 2018). People with low incomes often rely on urban gardening, due to lack of access to food (Artmann and Sartison, 2018). However, the potential "health risks" associated with UPA (especially with livestock production) cannot be neglected (Sanyé-Mengual et al., 2018).

Subsistence field crop farms produced for own consumption, while surpluses were sold to urban inhabitants (Chapter 2). Commercial livestock and commercial vegetable farms produce primarily for the local markets, and thereby contribute to food and nutrition security of urban inhabitants.

\subsection{Benefits and barriers of manure nutrient recycling in UPA farms}

The recycling and use of livestock manures and household wastes for soil fertility management has been explored in Chapters 2 to 5 as the current linear food productions systems results in the net transport of nutrients from food production areas to the food consumption areas. Recycling of livestock manures and household wastes to cropland is a necessity and a crucial strategy for closing the rural-urban nutrient loop and for the evolving circular economy. 
There is a widespread claim that UPA has environmental benefits of reducing urban wastes, improving urban biodiversity and reducing environmental impacts (Orsini et al., 2013). However, the claim about the environmental benefits of UPA are not sustained in this study, as livestock manures were not recycled, left unmanaged and dissipated in the urban environments of Addis Ababa, Adama and Jimma (Chapter 2). Jagisso et al. (2019) also reported that large amounts of manure with substantial fertilizer value had accumulated over years in the pastoralist households of Borana in Ethiopia. This is due to lack of insight on the potentials of recycling livestock manures. As a consequence, nutrients from livestock manures in urban and peri-urban areas in Ethiopia accumulate in farms and/or dissipate into the groundwater, surface waters and air.

From nutrient recycling perspective, mixed crop-livestock farms are preferred to the specialized crop or livestock farms, as mixed farms have greater potentials to improve nutrient recycling within the system, and thereby reduce the demand for inorganic fertilizer inputs (Ryschawy et al., 2012). However, the comparative advantage of mixed farms over the specialized crop and specialized livestock farms in nutrient recycling was not maintained in this study; mixed farms had lower N recycling index (NRI) than expected (Table 3.4). The low NRI of mixed farms was related to the relatively large $\mathrm{N}$ imports (Figure 6.2). Rufino et al. (2009b) reported little $\mathrm{N}$ recycling in crop-livestock farms, as the poor farm households used small quantities of $\mathrm{N}$ per capita and had low recycling index, indicating that these farms were dependent on $\mathrm{N}$ import to sustain the system.

The claim about reduced use of inorganic fertilizer in mixed farms, due to the better options of internal nutrient recycling (Ryschawy et al., 2012) was also not maintained across the mixed farms in our study. A relatively low $\mathrm{N}$ recycling and relatively large $\mathrm{N}$ import were observed in livestock-oriented mixed farms compared to crop-oriented mixed farms. The relatively large $\mathrm{N}$ import in livestock-oriented mixed farms is attributed to their relatively high farm income compared to crop-oriented mixed farms (Figure 6.2). The large $\mathrm{N}$ import in livestock-oriented mixed farms put pressure on the opportunities to recycle manure in mixed farms effectively. Spiertz (2010) confirmed that a low internal $\mathrm{N}$ use efficiency is the major concern of intensive systems with high external $\mathrm{N}$ inputs. This demands for a transition of low efficiency systems into highly resource-use efficient systems that are profitable, and at the same time ecologically safe and socially acceptable (Spiertz, 2010).

The presence of contaminants (plastics, pollutants, hormones and antibiotics) in manures and household wastes induces also concerns related to the recycling of livestock manures and household wastes in cropland. Although the risks of these contaminants are not considered in my thesis research, they present potential concerns in the recycling of livestock manures and household wastes, which should not be neglected. The impact of plastic waste is currently increasing in urban areas (Comanita et al., 2016; Verma et al., 2016). 


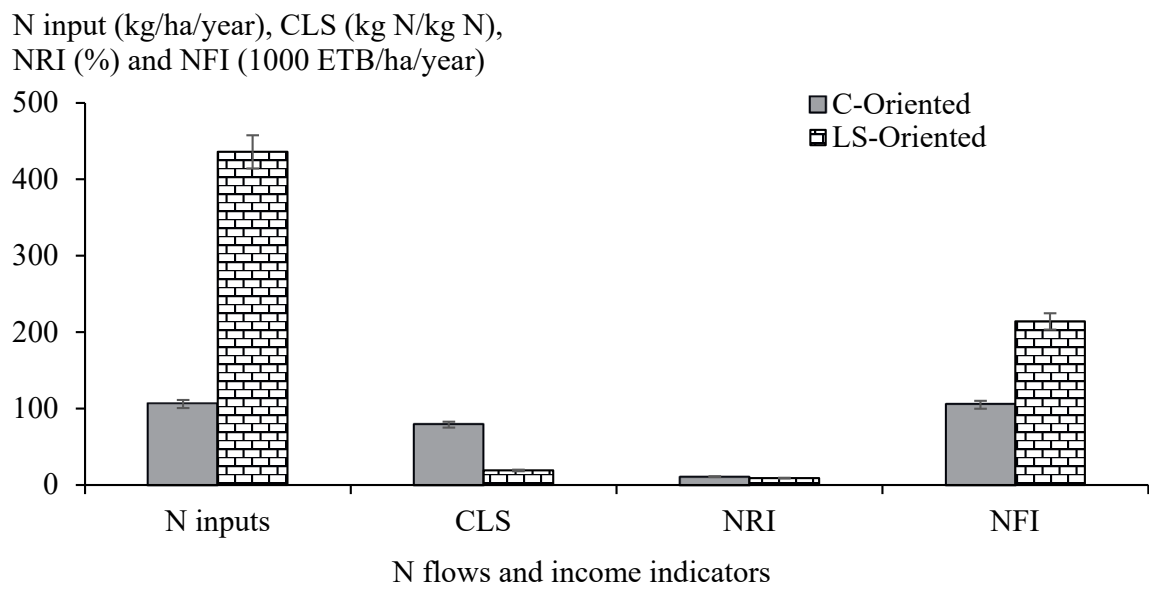

Figure 6.2 Mean N input, crop-livestock ratio (CLS), $\mathrm{N}$ recycling index (NRI) and net farm income (NFI) of mixed crop-livestock (MC-LS) farms with different $\mathrm{N}$ allocation strategies (i.e., crop-oriented and livestock-oriented) in Addis Ababa (See Chapter 3, Table 3.4).

\subsection{Options for improving nutrient use efficiency}

The rapidly growing human population and the increasing animal-source food consumption are fueling nutrient consumption in developing countries. These countries may account for $75 \%$ of the global nutrient consumption by 2050 (Sutton et al., 2013). Nutrient management options are required in the food production systems for increasing crop and livestock productivity and nutrient use efficiency (Pradhan et al., 2015). Recycling of organic wastes to supplement crop nutrient demands is a crucial element of sustainable food production systems (Akram et al., 2019) and entails the concept of the circular economy (Diacono et al., 2019; Tanzer et al., 2018).

The adoption of the 17 sustainable development goals (SDGs) by the United Nations (Dobermann, 2016), urge the scientific community to generate information for planning and monitoring socioeconomic developments and the underlying environmental components (Toth et al., 2018). Sutton et al. (2013) identified ten target areas for increasing nutrient use efficiency in their report 'Our nutrient world', namely (1) Improving nutrient use efficiency in crop production, (2) Improving nutrient use efficiency in animal production, (3) Increasing the fertilizer equivalence value of manure, (4) Low-emission combustion and energy-efficient systems, including renewable sources, (5) Development of NOx capture and utilization technology in energy combustion, (6) Improving nutrient efficiency through reducing food waste, (7) Recycling nitrogen and phosphorus from waste water systems, (8) Energy and transport saving, (9) Lowering personal consumption of animal protein among populations consuming high rates (avoiding excess and voluntary reduction), and (10) Spatial and temporal optimization of nutrient flows. Among the above ten targets, six (№. 1, 2, 3, 6, 7, 9 and 10) have been directly or indirectly addressed in my study. 
Among the five options considered for increasing manure $\mathrm{N}$ recycling (Table 3.2), option 2 $(30 \%$ manure $\mathrm{N}$ loss $+60 \%$ manure $\mathrm{N}$ recovery $+40 \%$ fertilizer $\mathrm{N}$ recovery) and option $5(30 \%$ manure $\mathrm{N}$ loss $+60 \%$ manure $\mathrm{N}$ recovery $+70 \%$ fertilizer $\mathrm{N}$ recovery) increased manure $\mathrm{N}$ recycling in livestock-oriented mixed farms. Similarly, option 5 increased manure $\mathrm{N}$ recycling in crop oriented mixed farms in urban regions of Addis Ababa and Jimma. It suggests that these two options may contribute to the first two targets identified by Sutton et al. (2013): 'improving nutrient use efficiency in crop production' and 'improving nutrient use efficiency in animal production', in mixed farms. In line with the results of our study, Reis et al. (2016) also reported that various $\mathrm{NH}_{3}$ emission mitigation options offer win-win results for the environment, human health and food security. Thus, these two nutrient management options are promising for mixed farms in Ethiopia and possibly elsewhere in Africa.

Ma et al. (2013a) suggested that improved nutrient management strategies must include (i) balanced fertilization in crop production, (ii) precision feeding and (iii) improved manure managements for increasing nutrient use efficiency in the food production systems. The balanced P fertilization strategy is important for manure allocation (Chapter 4), as it allowed greater precision in matching NP supply to NP demand, and was associated with more manure redistribution in crop production. This strategy of manure allocation partly addresses the $10^{\text {th }}$ target area identified by Sutton et al. (2013). This strategy of manure allocation should be implemented for efficient recycling of manure surpluses.

A combination of measures, including (i) reduced population growth and urbanization, (ii) improved livestock productivity (feed conversion efficiency and $\mathrm{N}$ use efficiency), and (iii) improved manure and waste recycling through reduced losses and improved collection, were considered in one of the scenarios (TECH scenario) in Chapter 5. The combination of these measures appeared most effective for matching regional food demand and food supply, and for drastically increasing manure recycling and nutrient use efficiency in UPA. These strategies can minimize the environmental effects of food systems. Springmann et al. (2018) reported that integrated use of different measures is needed to mitigate the anticipated increase in environmental effects, as a result of population and economic growth, as no single measure is enough to keep the environmental effects within the so-called 'planetary-boundaries'.

Increased population growth put large pressure on the food system of Ethiopia. To be able to maintain some degree of food self-sufficiency and minimize the need for large food import from other regions, population growth should be limited to $\leq 2.5 \% \mathrm{yr}^{-1}$. At the same time crop productivity will have to increase by $3 \% \mathrm{yr}^{-1}$, animal productivity has to double and animalderived protein intake should be limited to no more than $20 \%$ in Jimma (Chapter 5). The latter suggestion nicely goes with the $9^{\text {th }}$ target area identified by Sutton et al. (2013). Recent forecasts indicate that population growth in Ethiopia, especially in urban areas, will increase by on average $3 \%$ to $4 \%$ per year (UN, 2020), and that the demand for animal-derived food will increase in rapidly developing countries (Thornton, 2010), including Ethiopia. These forecasts must be seen as major wake-up calls for all stakeholders and actors. 


\subsection{Conclusions}

The general objective of my $\mathrm{PhD}$ thesis research is to increase the insights on the diversity, characteristics and performances of UPA farms and to analyze the potentials for recycling livestock manure and household waste nutrients for closing the urban-rural nutrient loops in Ethiopia. In this paragraph, I formulate the main conclusions of my research.

Six distinct UPA farm types with different resource endowments, level of household income and constraints were identified across the studied urban areas of Addis Ababa, Adama and Jimma. High costs of feed for livestock farms, high cost of nutrient and labor inputs for crop and vegetable farms, and land scarcity were the most important constraints for further UPA development. Therefore, to stimulate sustainable intensification of UPA, the access of farms to agricultural inputs should be improved and policies promoting the linking of crop and livestock farm systems should be put in place.

$>$ Mixed crop-livestock farms are dominant UPA systems. The diversity of mixed farms was captured by the crop-livestock ratio (CLS). Crop-oriented and livestock-oriented mixed farms were distinguished, which differed in farm income, $\mathrm{N}$ balances and nitrogen use efficiency.

$>$ Livestock farms in the urban zones of Addis Ababa and Jimma produce more manure $\mathrm{N}, \mathrm{P}$ and $\mathrm{K}$ than the demand of crop farms in the urban zones of these cities. A balanced $\mathrm{P}$ fertilization strategy was preferred to a balanced $\mathrm{N}$ fertilization strategy for estimating the allocation of manure in crop farms. Therefore, a balanced $P$ fertilization strategy should be used for the allocation of urban livestock manures and wastes and of their compost allocation to croplands.

$>$ Results of scenarios analyses indicated that animal-source food demand and thereby total manure $\mathrm{N}$ production in urban and peri-urban areas will likely increase by a factor of 3 to 10 in Jimma during the next three decades in response to population growth, urbanization and UPA intensification. This puts enormous pressure on agriculture and the environment. Three actions have been suggested to alleviate the pressures: (1) a slowdown in population growth and urbanization, (2) improvements in crop and animal productivity and (3) improved collection and utilization of manures and household.

\subsubsection{Recommendations for policy and industry}

Based on the results of my thesis research, the following main recommendations can be given.

1. Awareness should be created among farmers, agricultural experts and policy makers, about the importance of manures and wastes collection and recycling in urban areas for closing the urban-rural nutrient loops in Ethiopia. This requires the involvement of different stakeholders, incentives, investments, training and demonstration.

2. The exchange of high-quality feeds and manures between crop farms and livestock farms should be stimulated through governmental incentives and advisory services. 
3. There is large room for improving crop and livestock productivities and nutrient use efficiencies in agriculture in Ethiopia. This requires coordinated actions of many stakeholders, involving education, training, research and demonstration. The performances of mixed crop-livestock farms may be improved through genetic improvement in livestock breeds, feed quality improvement and precision feeding, improved crop husbandry practices, and improved nutrient management practices.

4. Financial incentives and regulations should be put in place to stimulate the use of urban manures and wastes in rural areas for crop production and improving soil fertility. Setting up commercial manure exchange services can facilitate manure recycling and at the same time create job opportunities for the young entrepreneurs and minimize urban and rural unemployment and food and nutrition insecurity.

5. Relatively large livestock farms need incentives to transfer manure surpluses to the nearby field and vegetable and crop farms, while the latter farmers need training to utilize the manure effectively. This may facilitate the re-coupling of animal and crop production systems and the implementation of the circular economy.

6. As a long-term intervention, slowing down population growth is required to reduce the pressure on the natural resources and the food production systems.

\subsubsection{Suggestions for future research}

Further research is needed to reap the potentials of UPA in enhancing urban nutrition security and increasing manure nutrients recycling and minimizing the pressure of UPA on the wider environment.

$>$ Collecting quantitative farm data and conducting scenario analyses to explore more sustainable development pathways for animal and crop production systems in urban areas.

$>$ Exploring options for improving land productivity and multifunctional land use, given the population pressure and scarcity of productive land in Ethiopia.

$>$ Improving NUE at animal level through animal breeding and precision animal feeding, for both commercial livestock farms and mixed crop-livestock in UPA systems of Ethiopia.

Answering the question whether the future is more in the direction of mixed crop-livestock farms with sufficient land for manure use/disposal or more in the direction of specialized and technically advanced, large and confined animal feeding operations with high manure nutrient recovery efficiency and potential. 


\section{Chapter 6}

\section{References:}

Abdulkadir A., Leffelaar P.A., Agbenin J.O., Giller K.E. (2013) Nutrient flows and balances in urban and peri-urban agroecosystems of Kano, Nigeria. Nutrient Cycling in Agroecosystems 95:231-254. DOI: 10.1007/s10705-013-9560-2.

Akram U., Quttineh N.H., Wennergren U., Tonderski K., Metson G.S. (2019) Enhancing nutrient recycling from excreta to meet crop nutrient needs in Sweden - a spatial analysis. Sci Rep 9:10264. DOI: 10.1038/s41598-019-46706-7.

Artmann M., Sartison K. (2018) The Role of Urban Agriculture as a Nature-Based Solution: A Review for Developing a Systemic Assessment Framework. Sustainability 10. DOI: 10.3390/su10061937.

Baudron F., Jaleta M., Okitoi O., Tegegn A. (2014) Conservation agriculture in African mixed crop-livestock systems: expanding the niche. Agric Ecosyst Environ 187:171-182. DOI: 10.1016/j.agee.2013.08.020.

Bon H., Parrot L., Moustier P. (2010) Sustainable urban agriculture in developing countries. A review. Agronomy for Sustainable Development 30:21-32. DOI: 10.1051/agro:2008062.

Chatterjee S., Goswami R., Bandopadhyay P. (2015) Methodology of Identification and Characterization of Farming Systems in Irrigated Agriculture: Case Study in West Bengal State of India. Journal of Agricultural Science and Technology 17:1127-1140.

Cofie O.O., Veenhuizen R.v., Drechsel P. (2003) CONTRIBUTION OF URBAN AND PERIURBAN AGRICULTURE TO FOOD SECURITY IN SUB-SAHARAN AFRICA:12.

Comanita E.-D., Hlihor R.M., Ghinea C., Gavrilescu M. (2016) Occurrence of Plastic Waste in the Environment: Ecological and Health Risks. Environmental Engineering and Management Journal 15:675-685. DOI: 10.30638/eemj.2016.073.

Diacono M., Persiani A., Testani E., Montemurro F., Ciaccia C. (2019) Recycling agricultural wastes and by-products in organic farming: Biofertilizer production, Yield performance and carbon footprint fnalysis. Sustainability 11. DOI: 10.3390/su11143824.

Dobermann A. (2016) Looking forward to 2030: Nitrogen and the Sustainable Development Goals. Proceedings of the 2016 International Nitrogen Initiative Conference.

Dorosh P., Schmidt E. (2010) The Rural-Urban Transformation in Ethiopia. IFPRI - ESSP2. Discussion Paper \# 13. International Food Policy Research Institute (IFPRI), Washington DC.

Finn J.T. (1980) Flow Analysis of Models of the Hubbard Brook Ecosystem. Ecology 61:562571. DOI: $10.2307 / 1937422$.

Garrett R., Niles M., Gil J., Dy P., Reis J., Valentim J. (2017a) Policies for Reintegrating Crop and Livestock Systems: A Comparative Analysis. Sustainability 9. DOI: 10.3390/su9030473.

Garrett R.D., Niles M.T., Gil J.D.B., Gaudin A., Chaplin-Kramer R., Assmann A., Assmann T.S., Brewer K., de Faccio Carvalho P.C., Cortner O., Dynes R., Garbach K., Kebreab E., Mueller N., Peterson C., Reis J.C., Snow V., Valentim J. (2017b) Social and 
ecological analysis of commercial integrated crop livestock systems: Current knowledge and remaining uncertainty. Agricultural Systems 155:136-146. DOI: 10.1016/j.agsy.2017.05.003.

Jagisso Y., Aune J., Angassa A. (2019) Unlocking the Agricultural Potential of Manure in Agropastoral Systems: Traditional Beliefs Hindering Its Use in Southern Ethiopia. Agriculture 9. DOI: 10.3390/agriculture9030045.

Jaleta M., Kassie M., Erenstein O. (2015) Determinants of maize stover utilization as feed, fuel and soil amendment in mixed crop-livestock systems, Ethiopia. Agricultural Systems 134:17-23. DOI: https://doi.org/10.1016/j.agsy.2014.08.010.

Junge R., Monsees H., Alencikiene G., Peticila A., Chrysargyris A., Tzortzakis N., Ćujić M., Paço T.A., Pedras C.M.G., Delgado C., Külvik M., Bohn K., Pölling B., Timpe A., Pineda-Martos R., Skar S.L.G. (2020) Urban agriculture as a keystone contribution towards securing sustainable and healthy development for cities in the future. BlueGreen Systems 2:1-27. DOI: 10.2166/bgs.2019.931.

Kumar S., Sieverding H., Lai L., Thandiwe N., Wienhold B., Redfearn D., Archer D., Ussiri D., Faust D., Landblom D., Grings E., Stone J.J., Jacquet J., Pokharel K., Liebig M., Schmer M., Sexton P., Mitchell R., Smalley S., Osborne S., Ali S., Şentürklü S., Sehgal S., Owens V., Jin V. (2019) Facilitating Crop-Livestock Reintegration in the Northern Great Plains. Agronomy Journal 111:2141-2156. DOI: 10.2134/agronj2018.07.0441.

Latruffe L., Diazabakana A., Bockstaller C., Desjeux Y., Finn J., Kelly E., Ryan M., Uthes S. (2016) Measurement of sustainability in agriculture: a review of indicators. Studies in Agricultural Economics 118:123-130. DOI: 10.7896/j.1624.

Ma L., Guo J., Velthof G.L., Li Y., Chen Q., Ma W., Oenema O., Zhang F. (2014) Impacts of urban expansion on nitrogen and phosphorus flows in the food system of Beijing from 1978 to 2008. Global Environmental Change 28:192-204. DOI: 10.1016/j.gloenvcha.2014.06.015.

Ma L., Wang F., Zhang W., Ma W., Velthof G., Qin W., Oenema O., Zhang F. (2013) Environmental assessment of management options for nutrient flows in the food chain in China. Environ Sci Technol 47:7260-8. DOI: 10.1021/es400456u.

Makita K., Fevre E.M., Waiswa C., Bronsvoort M.D., Eisler M.C., Welburn S.C. (2010) Population-dynamics focussed rapid rural mapping and characterisation of the periurban interface of Kampala, Uganda. Land use policy 27:888-897. DOI: 10.1016/j.landusepol.2009.12.003.

Marshall R.E., Farahbakhsh K. (2013) Systems approaches to integrated solid waste management in developing countries. Waste Manag 33:988-1003. DOI: $10.1016 / \mathrm{j}$. wasman.2012.12.023.

Negash D., Abegaz A., Smith J.U., Araya H., Gelana B. (2017) Household energy and recycling of nutrients and carbon to the soil in integrated crop-livestock farming systems: a case study in Kumbursa village, Central Highlands of Ethiopia. GCB Bioenergy 9:1588-1601. DOI: 10.1111/gcbb.12459.

Nigussie A., Kuyper T., de Neergaard A. (2015) Agricultural waste utilisation strategies and demand for urban waste compost: Evidence from smallholder farmers in Ethiopia. Waste Manag 44:82-93. DOI: 10.1016/j.wasman.2015.07.038. 
Orsini F., Kahane R., Nono-Womdim R., Gianquinto G. (2013) Urban agriculture in the developing world: a review. Agronomy for Sustainable Development 33:695-720. DOI: 10.1007/s13593-013-0143-z.

Pradhan P., Fischer G., van Velthuizen H., Reusser D.E., Kropp J.P. (2015) Closing Yield Gaps: How Sustainable Can We Be? PLoS One 10:e0129487. DOI: 10.1371/journal. pone. 0129487.

Reis S., Bekunda M., Howard C.M., Karanja N., Winiwarter W., Yan X., Bleeker A., Sutton M.A. (2016) Synthesis and review: Tackling the nitrogen management challenge: from global to local scales. Environ. Res. Lett. 11:14. DOI: 10.1088/17489326/11/12/120205.

Roberts T. (2008) Improving Nutrient Use Efficiency. Turk J Agric 32:177-182.

Rufino M.C., Tittonell P., Reidsma P., López-Ridaura S., Hengsdijk H., Giller K.E., Verhagen A. (2009) Network analysis of $\mathrm{N}$ flows and food self-sufficiency - a comparative study of crop-livestock systems of the highlands of East and southern Africa. Nutrient Cycling in Agroecosystems 85:169-186. DOI: 10.1007/s10705-009-9256-9.

Ryan M., Hennessy T., Buckley C., Dillon E.J., Donnellan T., Hanrahan K., Moran B. (2016) Developing farm-level sustainability indicators for Ireland using the Teagasc National Farm Survey. Irish Journal of Agricultural and Food Research 55:112-125 DOI: DOI: 10.1515/ijafr-2016-0011

Ryschawy J., Choisis N., Choisis J.P., Joannon A., Gibon A. (2012) Mixed crop-livestock systems: an economic and environmental-friendly way of farming? Animal 6:1722-30. DOI: $10.1017 / \mathrm{S} 1751731112000675$.

Saam H., Mark Powell J., Jackson-Smith D.B., Bland W.L., Posner J.L. (2005) Use of animal density to estimate manure nutrient recycling ability of Wisconsin dairy farms. Agricultural Systems 84:343-357. DOI: 10.1016/j.agsy.2004.06.020.

Sanyé-Mengual E., Orsini F., Gianquinto G. (2018) Revisiting the Sustainability Concept of Urban Food Production from a Stakeholders' Perspective. Sustainability 10. DOI: 10.3390/su10072175.

Savickiene J., Miceikiene A. (2018) Sustainable economic development assessment model for family farms. Agricultural Economics (Zemědělská ekonomika) 64:527-535. DOI: 10.17221/310/2017-agricecon.

Shrestha P., Small G.E., Kay A. (2020) Quantifying nutrient recovery efficiency and loss from compost-based urban agriculture. PLoS One 15:e0230996. DOI: 10.1371/journal. pone.0230996.

Snijders P., Davies O., Bram W., Louis G., Joshua Z., Peter E., Kebebe E., Muktar A., van Keulen H. (2009) Cattle manure management in East Africa: Review of manure quality and nutrient losses and scenarios for cattle and manure management, Integrated Nutrient Management to Attain Sustainable Soil Productivity increases in East African farming systems (INMASP).

Spiertz J.H.J. (2010) Nitrogen, sustainable agriculture and food security. A review. Agronomy for Sustainable Development 30:43-55. DOI: 10.1051/agro:2008064.

Springmann M., Clark M., Mason-D'Croz D., Wiebe K., Bodirsky B.L., Lassaletta L., de Vries W., Vermeulen S.J., Herrero M., Carlson K.M., Jonell M., Troell M., DeClerck F., 
Gordon L.J., Zurayk R., Scarborough P., Rayner M., Loken B., Fanzo J., Godfray H.C.J., Tilman D., Rockstrom J., Willett W. (2018) Options for keeping the food system within environmental limits. Nature 562:519-525. DOI: 10.1038/s41586-018-0594-0.

Sutton M.A., Bleeker A., Howard C.M., Bekunda M., Grizzetti B., de Vries W., van Grinsven H.J.M., Abrol Y.P., Adhya T.K., Billen G., Davidson E.A., Datta A., Diaz R., Erisman J.W., Liu X.J., Oenema O., Palm C., Raghuram N., Reis S., Scholz R.W., Sims T., Westhoek H., Zhang F.S. (2013) Our Nutrient World: The challenge to produce more food and energy with less pollution. Global Overview of Nutrient Management.

Tadesse S.T., Oenema O., van Beek C., Ocho F.L. (2018) Diversity and nutrient balances of urban and peri-urban farms in Ethiopia. Nutrient Cycling in Agroecosystems 111:1-18. DOI: 10.1007/s10705-018-9911-0.

Tanzer J., Zoboli O., Zessner M., Rechberger H. (2018) Filling two needs with one deed: Potentials to simultaneously improve phosphorus and nitrogen management in Austria as an example for coupled resource management systems. Sci Total Environ 640641:894-907. DOI: 10.1016/j.scitotenv.2018.05.177.

Thornton P.K. (2010) Livestock production: recent trends, future prospects. Philos Trans R Soc Lond B Biol Sci 365:2853-67. DOI: 10.1098/rstb.2010.0134.

Toth G., Hermann T., da Silva M.R., Montanarella L. (2018) Monitoring soil for sustainable development and land degradation neutrality. Environ Monit Assess 190:57. DOI: 10.1007/s10661-017-6415-3.

Valbuena D., Tui S.H.-K., Erenstein O., Teufel N., Duncan A., Abdoulaye T., Swain B., Mekonnen K., Germaine I., Gérard B. (2015) Identifying determinants, pressures and trade-offs of crop residue use in mixed smallholder farms in Sub-Saharan Africa and South Asia. Agricultural Systems 134:107-118. DOI: 10.1016/j.agsy.2014.05.013.

van Beek C.L., Elias E., Yihenew G.S., Heesmans H., Tsegaye A., Feyisa H., Tolla M., Melmuye M., Gebremeskel Y., Mengist S. (2016) Soil nutrient balances under diverse agro-ecological settings in Ethiopia. Nutrient Cycling in Agroecosystems 106:257-274. DOI: $10.1007 / \mathrm{s} 10705-016-9803-0$.

van Leeuwen M.M.W.J., van Middelaar C.E., Oenema J., van Dam J.C., Stoorvogel J.J., Stoof C.R., de Boer I.J.M. (2019) The relevance of spatial scales in nutrient balances on dairy farms. Agriculture, Ecosystems \& Environment 269:125-139. DOI: 10.1016/j.agee. 2018.09.026.

Verma R., Vinoda K.S., Papireddy M., Gowda A.N.S. (2016) Toxic Pollutants from Plastic Waste-A Review. Procedia Environmental Sciences 35:701-708. DOI: 10.1016/j. proenv.2016.07.069.

Wielemaker R., Oenema O., Zeeman G., Weijma J. (2019) Fertile cities: Nutrient management practices in urban agriculture. Sci Total Environ 668:1277-1288. DOI: $10.1016 / \mathrm{j}$. scitotenv.2019.02.424.

Zhang F., Ying H., Dou Z., Cui Z. (2020) Producing more with less: reducing environmental impacts through an integrated soil-crop system management approach. Frontiers of Agricultural Science and Engineering 7. DOI: 10.15302/j-fase-2019295. 


\section{APPENDIX}




\section{Appendix 5S}

Supplementary Information for Chapter 5: Exploring the recycling of manure from urban livestock farms: a case-study in Ethiopia

\section{Includes:}

A. Explanation of modelling approaches, parameters and assumptions for scenario analysis,

B. Explanation of the scenarios,

C. Supplementary figures of the scenario analysis (including 2 Figures),

D. Description and detailed results of the field experiment. 


\section{A. Explanation of modelling approach, conversion efficiencies, set of assumptions and parameters used in the model for scenario analysis}

\section{Model concept}

Jimma is one of the circa 20 cities with 0.1 to 0.4 million people in the southwest of Ethiopia, next to the capital Addis Ababa with 3.4 million people in 2018. Jimma was chosen as 'model' city to explore the effects of population growth, urbanization, intensification of urban and periurban agriculture (UPA) and technological measures on food production and nitrogen (N) flows and recycling in animal manure, kitchen waste and sewage waste for the period 2015 to 2050. Previous field work had provided some basic data of UPA farms in Jimma (and also in Addis Ababa and Adama) by the authors (Tadesse et al., 2018, 2019).

Cities are often an asymmetrical, uneven and multi-dimensional continuum of zones, with slow changes between the center and urban, peri-urban and rural settings around the center. The idea of a circular patterns of zones of early settlements and cities dates back to the ideas of Von Thünen (Sinclair, 1967), and was adopted in our model. Hence, Jimma was considered to consist of a circular city center with an urban zone, a peri-urban zone and a rural zone around the center. The city center, and the urban and peri-urban zones were considered as Jimma city, while Jimma city with the rural zone around it was considered here as 'Jimma'. The size of the zones was based on literature data, interviews with local officials and expert judgement. In the end, the total area of the four zones and the population was chosen such that the overall mean population density of Jimma was about 200 residents $\mathrm{km}^{-2}$, which is more or less the average of the highlands in Ethiopia, i.e., the central/south-western area of the country where most people are living (i.e., not considering the sparsely populated and semi-arid south-eastern part of the country). Thus, Ethiopia was conceptualized in circular settlements (villages, cities), which vary in size according to the population (density), and Jimma was considered to be a model city for this concept.

Based on earlier surveys (Tadesse et al., 2018, 2019) and following the ideas of Von Thünen, the productivity of the land was considered to be highest near the center and least in the rural area. Average cereal grain yield in Africa is $<2 \mathrm{t} \mathrm{ha}^{-1} \mathrm{yr}^{-1}$ and in Ethiopia $2.5 \mathrm{t} \mathrm{ha}^{-1} \mathrm{yr}^{-1}$ (Connor et al., 2011; FAOSTAT, 2020). We assumed compound dry matter yields of $2 \mathrm{t} \mathrm{ha}^{-1} \mathrm{yr}^{-1}$ in the rural area and of $3 \mathrm{tha}^{-1} \mathrm{yr}^{-1}$ in the urban and peri-urban areas in the base year 2015. Compound crop protein- $\mathrm{N}$ yields in the base year were set at 40, 60 and $75 \mathrm{~kg} \mathrm{ha}^{-1} \mathrm{yr}^{-1}$ for the rural, periurban and urban zones, respectively. Livestock production was derived from farm surveys (Tadesse et al., 2018, 2019).

We assumed in all four zones a mean gross protein consumption of $22 \mathrm{~kg} \mathrm{capita}^{-1} \mathrm{yr}^{-1}$ in 2015 , which is the African average (Connor et al., 2011; FAOSTAT, 2020), with 20\% food losses and food waste. Animal-sourced protein consumption was set at $14 \%$ of the total protein consumption, based on statistical data (Connor et al., 2011; FAOSTAT, 2020). The average supply of protein of animal origin has been decreasing in Ethiopia from about $13 \%$ in 2008 to about $10 \%$ in 2017 , due to a precarious food supply situation. We assumed that the animal- 
sourced protein intake in Jimma was slightly higher than the Ethiopian average, because of the productivity of the land around Jimma.

\section{Model calculations}

A simple $\mathrm{N}$ mass flow model was developed in Windows Excel to explore the effects of scenarios of possible developments. Calculations were done for the four zones of Jimma (Table 5.1) at annual basis (2015-2050). The model had four modules (i) protein consumption and household waste production, (ii) milk, meat and egg production and manure production, (iii) crop production and $\mathrm{N}$ balances, and (iv) economic cost of manure and waste collection, composting and transport. The first three modules were largely based on the ideas of the NUFER model (Ma et al., 2010; Wang et al., 2018) and follows the principles of substance flow analysis, in this case N. The fourth module was developed for the purpose of this study; it considers the costs of manure and waste collection, storage, composting, transport and compost delivery/marketing.

The NUFER model has been used to analyze the effects of urban expansion of Beijing, China on $\mathrm{N}$ and P flows for the period 1978 to 2008 (Ma et al., 2014). NUFER has also been used for several case studies at regional level in China (Strokal et al., 2016; Wang et al., 2018), and for case studies in Hungary (Hou et al., 2015) and Kenya (Dorris, 2020). NUFER (NUtrient flows in Food chains, Environment and Resources use) is a 'static' model, developed to analyze N and $\mathrm{P}$ use efficiencies and losses in crop and animal production, food processing and consumption in rural and urban households at regional level. NUFER consists of a database with statistical data, and of various calculation modules, which calculate the transfer of $\mathrm{N}$ (and $\mathrm{P}$ ) from one compartment to another (and from one $\mathrm{N}$ form to another $\mathrm{N}$ form), using transfer coefficients. In NUFER, food systems of a city/region/country are perceived as "pyramids" with four main compartments namely crop production including the rootable soil layer, animal production, food processing and households (consumption). The space outside the pyramid includes the environment (air, surface water, groundwater) and other food systems (pyramids). Nutrients enter the pyramid via fertilizers, biological $\mathrm{N}_{2}$ fixation, atmospheric deposition, and imported products from other regions or countries. They leave the pyramid via exported products and losses to air and water. There are internal exchanges of $\mathrm{N}$ and $\mathrm{P}$ within the pyramid between compartments via crop and animal products from the sites of production, processing to consumption and waste production/recycling. Natural grasslands, rough grazing, forests, lakes, and seas are perceived as natural ecosystems and products harvested from these systems are considered as inputs to the pyramid (Ma et al., 2010; Ma et al., 2012; Ma et al., 2013a).

Below, we briefly describe the simple $\mathrm{N}$ mass flow model in Windows Excel. For each of the four zones of Jimma (city center, urban area, peri-urban area, and rural area; see Table 5.1) the model calculates for each year, from 2015 to 2050:

- Total human population

- Total plant and animal-source protein requirements of the population

- Total milk, meat and egg consumption and total plant-source protein consumption 
- Total production of kitchen waste $\mathrm{N}$, and total $\mathrm{N}$ losses from kitchen wastes

- Total production of sewage waste $\mathrm{N}$, and $\mathrm{N}$ losses from sewage wastes

- Total feed-protein required by dairy cattle, beef cattle (+goat/sheep) and poultry

- Total crop-protein (including feed-protein) production and the crop $\mathrm{N}$ requirements

- Total import of feed-protein and plant-protein needed to satisfy the remaining demand ${ }^{1}$

- Total N-excretion by dairy cattle, beef cattle (including goat/sheep) and poultry

- Total amount of collected animal manure N, and N losses from manure during storage

- The cost of manure and wastes collection

- The cost of manure and wastes composting

- The loss of $\mathrm{C}$ and $\mathrm{N}$ during composting

- The cost of compost delivering to farms

- Total amounts of compost $\mathrm{N}$ available and the 'additional' $\mathrm{N}$ (fertilizer + BNF) needed to satisfy crop demand

- Overall $\mathrm{N}$ use efficiency of the food system and the total $\mathrm{N}$ surplus

Table 5.S1 provides an overview of the baseline data parameter values in the Business as usual (BAU) scenario. Baseline data refer to the population, surface areas, protein consumption, milk, meat and egg consumption in the four areas. There was no information available about any differentiation in diets of urban, peri-urban and rural areas in Jimma in 2015. Hence, consumption was set at uniform levels for all areas, and were derived from literature (Ayele and Peacock, 2003; Schonfeldt and Hall, 2012).

In the model, population and changes in population drives protein $\mathrm{N}$ demand. The relative proportions of plant-derived, milk-derived, meat-derived and egg-derived protein consumption in 2015 were derived from survey data.

The conversion efficiency of feed protein into milk, meat and egg was derived from literature (e.g., (McDonald P. et al., 2010; Oenema and Tamminga, 2005; Snijders et al., 2009). These values and the self-sufficiency coefficients of milk, meat and egg production, the percentage feed scavenging from non-agricultural land, mortality losses, $\mathrm{N}$ losses from wastes and manure during storage, the collection and composting of waste and manures in the four zones have the nature of 'guestimates', because there are no accurate data.

The costs for manure and waste collection, composting and transport were derived from interviews with locals; these costs are uncertain, also because there are no existing commercial services for manure and waste collection, storage, composting, transport and delivery/marketing. There is extensive data available on the cost of manure transport in some countries in Europe (e.g., The Netherlands; https://www.agrimatie.n1/SectorResultaat.aspx?subpubID=2232 \& sector ID $=2255$ \& thema $\mathrm{ID}=2282$ \&indicatorID $=6622$ ), but the socio-economic conditions in Jimma and Ethiopia are

\footnotetext{
${ }^{1}$ In case the local crop production does not meet the local demand.
} 
completely different and hence these data cannot be used. Evidently, there is a need for further research here.

The model accounts for new additional $\mathrm{N}$ inputs (via biological $\mathrm{N}_{2}$ fixation and fertilizers), recycling of manure and waste $\mathrm{N}$ in cropland, and for $\mathrm{N}$ losses during manure and waste storage and composting and following application to cropland. The required additional $\mathrm{N}$ input via biological $\mathrm{N}_{2}$ fixation and mineral $\mathrm{N}$ fertilizers $\left(\mathrm{N}\right.$-inputs; $\mathrm{kg} \mathrm{ha}^{-1} \mathrm{yr}^{-1}$ ) was estimated from the following mass balance: $\mathrm{N}$-input $\mathrm{N}=$ crop protein-N yield $* \mathrm{NUE}^{-1}-\left(\mathrm{N}-\right.$-input $\left._{\mathrm{M}} * \mathrm{FRV}_{\mathrm{M}}\right)$, where $\mathrm{N}$-input $\mathrm{M}$ is the $\mathrm{N}$ input via manure and composts $\left(\mathrm{kg} \mathrm{ha}^{-1} \mathrm{yr}^{-1}\right), \mathrm{FRV}_{\mathrm{M}}$ is the fertilizer $\mathrm{N}$ replacement value of manures and composts ( $\%$, ranging from $40 \%$ to $60 \%$; Table 2 ), and NUE is the $\mathrm{N}$ use efficiency in crop production ( $\%$, ranging from $40 \%$ to $60 \%$; Table 2 ).

Farm-gate balances were derived from the difference between the inputs via imported animal feed (from the rural areas into UPA) and additional $\mathrm{N}$ (via biological $\mathrm{N}_{2}$ fixation and mineral fertilizer), and the output of harvested crop and animal produce. Care was taken that the 'Law of mass conservation' (in this case the mass of $\mathrm{N}$ ) holds in all calculations. We assumed that the soil was not a (temporary) net source of $\mathrm{N}$, although soil $\mathrm{N}$ mining is a rather common phenomenon in the rural areas of Ethiopia (Tadesse et al., 2018, 2019).

The model is available for reviewers (uploaded to the website of FASE journal) and to readers at request. Please send an email to the first author (soltuta@gmail.com). The model will be made available also on the FASE Journal portal.

The assumptions of conversion efficiencies and parameters used in model calculations (Table 5.S1) are summarized below.

Table 5.S1 Overview of the baseline data and parameter values in the Business as usual (BAU) scenario for the base year 2015. These parameter values were either based on local statistical data (Cochrane and Bekele, 2018; UN, 2019), field survey and interview data (Tadesse et al., 2018, 2019), literature data and guestimates (see text).

\begin{tabular}{lllll}
\hline Parameters & City center & Urban area & $\begin{array}{l}\text { Peri-urban } \\
\text { area }\end{array}$ & $\begin{array}{l}\text { Rural } \\
\text { area }\end{array}$ \\
\hline Population (million) & 0.02 & 0.1 & 0.15 & 0.12 \\
Protein-N consumption (kg/cap/yr) & 22 & 22 & 22 & 22 \\
Milk consumption (kg/cap/yr) & 33 & 33 & 33 & 33 \\
Milk protein-N content (g/kg) & 5.17 & 5.17 & 5.17 & 5.17 \\
Meat consumption $(\mathrm{kg} / \mathrm{cap} / \mathrm{yr})$ & 5 & 5 & 5 & 5 \\
Meat protein-N content $(\mathrm{g} / \mathrm{kg})$ & 25.1 & 25.1 & 25.1 & 25.1 \\
Egg consumption $(\mathrm{kg} / \mathrm{cap} / \mathrm{yr})$ & 4 & 4 & 4 & 4 \\
Egg protein-N content $(\mathrm{g} / \mathrm{kg})$ & 18.81 & 18.81 & 18.81 & 18.81 \\
Food waste and losses (\%) & 20 & 20 & 20 & 20 \\
Self-sufficiency milk production $(\%)$ & 0 & 20 & 30 & $>100$ \\
Self-sufficiency meat production $(\%)$ & 0 & 20 & 30 & $>100$ \\
Self-sufficiency egg production $(\%)$ & 0 & 20 & 30 & $>100$ \\
& & & & \\
Surface areas (km ${ }^{2}$ ) & 78.5 & 235.5 & 392.5 & 1256 \\
Agricultural land $(\%$ of total area) & 0 & 5 & 20 & 60 \\
Mean crop yield (dry matter) (kg/ha/yr) & na & 3000 & 3000 & 2000
\end{tabular}


Mean crop protein-N content $(\mathrm{g} / \mathrm{kg})$

Conversion of feed-N into milk N (\%)

Conversion of feed-N into meat N (\%)

Conversion of feed-N into egg N (\%)

Feed $\mathrm{N}$ scavenged by dairy cattle (\%)

Feed $\mathrm{N}$ scavenged by beef cattle (\%)

Feed $\mathrm{N}$ scavenged by poultry ( $\%)$

Mortality losses dairy production (\%)

Mortality losses meat production (\%)

Mortality losses poultry production (\%)

$\mathrm{N}$ losses kitchen waste storage (\%)

$\mathrm{N}$ losses human waste storage (\%)

$\mathrm{N}$ losses cattle manure storage (\%)

$\mathrm{N}$ losses poultry manure storage (\%)

$\mathrm{N}$ content kitchen waste $(\mathrm{g} / \mathrm{kg})$

$\mathrm{N}$ content sewage waste $(\mathrm{g} / \mathrm{kg})$

$\mathrm{N}$ content cattle manure $(\mathrm{g} / \mathrm{kg})$

$\mathrm{N}$ content poultry manure $(\mathrm{g} / \mathrm{kg})$

Fertilizer-N effectiveness of compost (\%)

$\mathrm{N}$ use efficiency applied fertilizer $\mathrm{N}(\%)$

$\mathrm{N}$-use efficiency BNF (\%)

Amount of kitchen waste collected (\%)

Amount of human waste collected (\%)

Amount of cattle manure collected (\%)

Amount of poultry manure collected (\%)

Collection cost kitchen waste (Birr/Mg)

Collection cost human waste (Birr/Mg)

Collection cost cattle manure (Birr/Mg)

Collection cost poultry manure (Birr/Mg)

Composting cost kitchen waste (Birr/Mg)

Composting cost human waste (Birr/Mg)

Composting cost cattle manure (Birr/Mg)

Composting cost poultry manure (Birr/Mg)

Composting $\mathrm{N}$ losses (\%)

Mean compost transport distance $(\mathrm{km})$

Compost transport cost (Birr $/ \mathrm{Mg} / \mathrm{km})$

Transaction costs of compost (Birr/Mg)

na $=$ not applicable
25

25

20

na

na

10

5

20

20

20

20

10

5

20

20

20

20

10

10

10

50

50

50

50

10

5

20

20

20

20

10

10

10

50

50

50

50

5

10

5

20

40

40

100

50

0.1

50

50

100

300

100

100

100

300

100

100

30

20

10

50
50

0.1

50

50

100

300

100

100

100

300

100

100

30

10

10

50

Population growth rate in the baseline data was set at $3 \%$ year $^{-1}$, but in reality, differs between rural and urban areas (FAOSTAT, 2020). Population growth was $4.36 \%$ year $^{-1}$ in Addis Ababa in the period 2016-2020 (UN, 2019).

Estimates of protein intake by residents differ somewhat between the available literature sources (Ayele and Peacock, 2003; de Bruyn et al., 2016; Workicho et al., 2016). We assumed a gross protein intake of $22 \mathrm{~kg}_{\text {person }}{ }^{-1} \mathrm{yr}^{-1}$ for the year 2015. This is slightly lower compared to the total protein intake of $23 \mathrm{~kg}$ person ${ }^{-1} \mathrm{yr}^{-1}$ recorded in 2005 and with an increase of $1 \%$ $\mathrm{yr}^{-1}$ (Schonfeldt and Hall, 2012), but slightly higher compared to the data of FAOSTAT 
(FAOSTAT, 2020). Food waste losses were set at 20\%, based on data that indicate that food waste in SSA is on average $150 \mathrm{~kg}$ of food person ${ }^{-1}$, and that $15 \%$ to $35 \%$ of the food harvested may be lost, depending on the crop (Alexander et al., 2017; Ayele and Peacock, 2003; Ghosh et al., 2016). The total protein food loss at global level is estimated at $22 \%$ (Alexander et al., 2017; Ghosh et al., 2016), which is close to our assumption. The $2.5 \mathrm{~kg}_{\text {person }}{ }^{-1} \mathrm{yr}^{-1}$ of animal protein intake we assumed for the year 2015 is slightly lower than the animal protein intake of $2.9 \mathrm{~kg}$ person $^{-1} \mathrm{yr}^{-1}$ reported for Ethiopia by the year 2003 (Ayele and Peacock, 2003; Enahoro et al., 2018), but slightly higher compared to the data of FAOSTAT (FAOSTAT, 2020). The animal-sourced products intake (20\%) we assumed for the base year 2015 is comparable to the estimated animal protein intake in SSA (Ayele and Peacock, 2003; de Bruyn et al., 2016; Workicho et al., 2016).

The fertilizer $\mathrm{N}$ replacement value of composts (40\% to $60 \%)$ we assumed is an average compared to the relative efficiencies of manure $\mathrm{N}$ as compared to commercial fertilizer $\mathrm{N}$ that ranges from less than $30 \%$ to greater than $100 \%$ (Wilkinson, 1979). Similarly, our assumption of animal productivity that we defined in terms of feed $\mathrm{N}$ conversion is an average compared to the $\mathrm{N}$ in feed protein converted to and deposited in animal protein that ranges between $5 \%$ and 45\% (Arndt et al., 2015; Oenema and Tamminga, 2005).

\section{B. Explanation of the scenarios}

Four main contrasting scenarios for possible future developments were defined (Table 5.2, main text). This section provides some further background of the chosen scenarios (variants). The baseline or Business as usual (BAU) reflects stagnant developments in urbanization, crop and animal production and production efficiency, but a steady population growth of $3 \% \mathrm{yr}^{-1}$ (Abrha et al., 2015). Stagnant crop yields were assumed to be the result of soil fertility decline, lack of sufficient fertilizer input and lack of development in agronomic advice and support. While initial calculations indicate that sufficient food was produced for the people and animals in Jimma in the base year (2015), this BAU scenario indicates that massive amounts of food will have to be imported from other areas and/or from abroad to secure the set food protein intake by the residents by 2050 . This scenario served as a worse case.

Urbanization is still rather limited in Ethiopia (20\% urban people in 2015), but is increasing rapidly by $\geq 3 \% \mathrm{yr}^{-1}$. The urbanization scenario (URBAN) was set up to explore the effects of increased growth of urban people $\left(5 \% \mathrm{yr}^{-1}\right)$ and a modest growth of the rural population $(1 \%$ $\left.\mathrm{yr}^{-1}\right)$. The increased urbanization was meant to reflect increased economic development in the urban areas and increasing prosperity of especially urban people. The changes in productivity and production efficiency partially reflect the changes that have occurred in China during the last 30 to 50 year (Zhang et al., 2013). We assumed a modest increase in protein consumption per capita of $1 \% \mathrm{yr}^{-1}$ and also an increase in animal-sourced food consumption of $1 \%$ capita $^{-1}$ $\mathrm{yr}^{-1}$ (Table 5.2). Cereal productivity in China has increased by on average 70 to $90 \mathrm{~kg} \mathrm{ha}^{-1} \mathrm{yr}^{-1}$ during the last 55 years (FAOSTAT, 2020). For Jimma, we assumed an increase in compound crop yield of $3 \% \mathrm{yr}^{-1}$, which boils down for the rural areas to a mean increase of $100 \mathrm{~kg} \mathrm{ha}^{-1} \mathrm{yr}^{-}$ 
${ }^{1}$ for the period 2015 to 2050 and to a modest initial increase of $60 \mathrm{~kg} \mathrm{ha}^{-1} \mathrm{yr}^{-1}$ during the first $5 \mathrm{yrs}$. Evidently, this assumed increase in average compound crop yield is at the upper level of what is agronomically and technically feasible, and cannot be extrapolated further. It requires massive input or agronomic knowledge and support, as is being done in the Chinese case (e.g., (Chen et al., 2014; Chen et al., 2011; Cui et al., 2018)). Because of the increased population growth in the urban area, we assumed a steady decrease in the area of cropland in the urban and peri-urban areas $\left(2 \% \mathrm{yr}^{-1}\right)$, and also a decrease in the percentage of feed that can be scavenged by livestock in communal areas in the urban environment (Table 5.2). As a result of the decreasing agricultural area in the urban and peri-urban zones, more food and feed protein are needed to be imported from the rural areas (and other areas) to be able to meet the demand in the urban areas.

The scenario of increased (intensification of) livestock production in UPA (UPALP) builds on the URBAN scenario. We assumed that livestock production in UPA was doubled relative to the production in URBAN, and that the increase in animal-sourced food consumption by the urban people was also doubled, from $1 \%$ to $2 \% \mathrm{yr}^{-1}$ (Table 5.2). Because, the protein consumption in the basal year 2015 was low, doubling the rate of increase of animal-sourced protein consumption turned out to be modest; total net protein intake capita ${ }^{-1}$ increased from 17.6 to $24.9 \mathrm{~kg} \mathrm{yr}^{-1}$, and the overall mean animal-sourced protein intake increased from $14 \%$ to $19 \%$ (also because the animal-sourced protein intake in the rural areas was not doubled). Other parameters were as in the URBAN scenario.

The technology scenario (TECH) builds on the UPALP scenario. We assumed that the population growth in the urban areas was halved and that technological measures were taken (i) to increase livestock productivity per animal (a doubling of the amount of feed protein converted into milk, meat, and egg protein), (ii) to decrease $\mathrm{N}$ losses from manures and wastes during storage, and (iii) to increase the $\mathrm{N}$ use efficiency in crop production, relative to the UPALP scenario (Table 5.2). A slowing down of population growth in developing countries is possible, as shown by the Chinese case (Gietel-Basten et al., 2019), but not easy. It requires economic growth and various governmental incentives.

Ethiopia has a relatively large number of livestock, but its productivity is relatively low (FAOSTAT, 2020). Feed availability and quality are major constraints, but the genetic potential of the herd and, the herd and disease management provide also opportunities for improvement. In the TECH scenario, we explored the effects of doubling of livestock productivity, i.e., the amounts of milk, meat and egg produced per unit of feed protein intake per head was increased by a factor of two. Thus, the feed protein conversion by dairy cattle, sheep, goat and poultry was doubled; it increased to levels which are considered to be close to current averages in China but are still below the performance of the best performing countries (Bai et al., 2018c; Oenema and Tamminga, 2005).

Next, we assumed that the $\mathrm{N}$ losses from wastes and manures during storages was halved from $50 \%$ to $25 \%$ by technical measures (leak-tight and covered storages), and that the collection of 
manures and wastes was increased from $50 \%$ to $75 \%$ (i.e., $75 \%$ of the collectable waste and manures were indeed collected). These estimates were largely based on (Bittman et al., 2014).

Further, we assumed that the overall $\mathrm{N}$ use efficiency in crop production was increased from a base compound level of $40 \%$ to a compound average efficiency of $60 \%$. Nitrogen use efficiency (NUE) was defined as the ratio between harvested output and total $\mathrm{N}$ input. The world-average NUE was $42 \%$ in 2010, while the average for Sub-Saharan Africa was $72 \%$ in 2010 (Zhang et al., 2015). The latter value reflects low input and soil $\mathrm{N}$ mining. It has been suggested that the world-average NUE should increase close of $70 \%$ by 2050 (including Sub-Saharan Africa) to be able to produce sufficient food and stay within the proposed planetary boundaries (Zhang et al., 2015). Our suggested increases for NUE in Jimma are within the suggested ranges.

Evidently, the TECH scenario is the most demanding scenario. It provides a dot on the horizon; it may indicate the needed future direction.

We made a number of additional sensitivity analyses, in addition to the aforementioned four main scenarios. These sensitivity analyses provided insight in the most sensitive indicators, and helped to define the main scenarios. Results of these sensitivity analyses are not shown here, but are available on request. 


\section{Supplementary figures of the scenario analysis (including 2 Figures)}
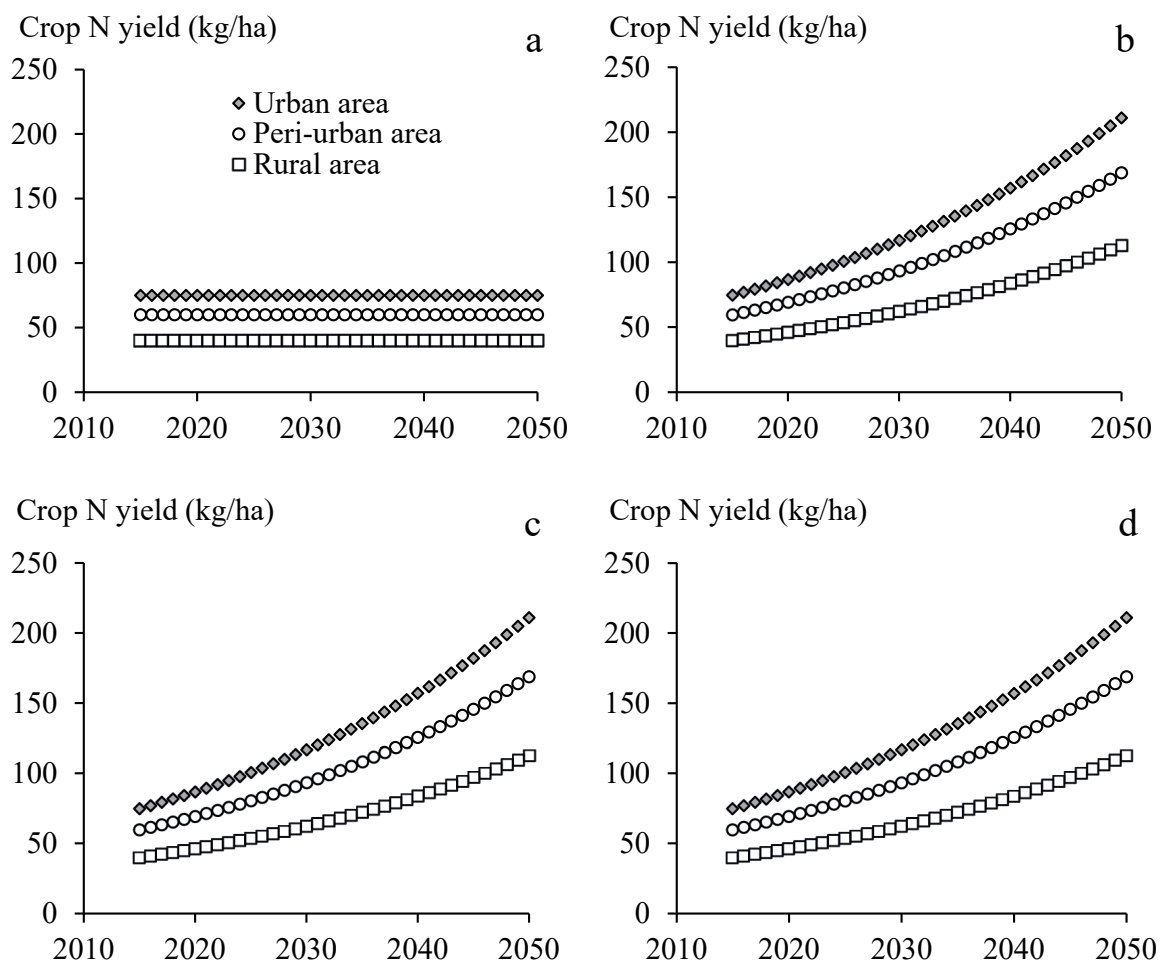

Figure 5.S1 Simulated changes in the crop N yields in different zones of Jimma in the period 2015 to 2050, for four scenarios: (a) BAU, (b) URBAN, (c) UPALP, and (d) TECH (see Table 5.2 for assumptions). 


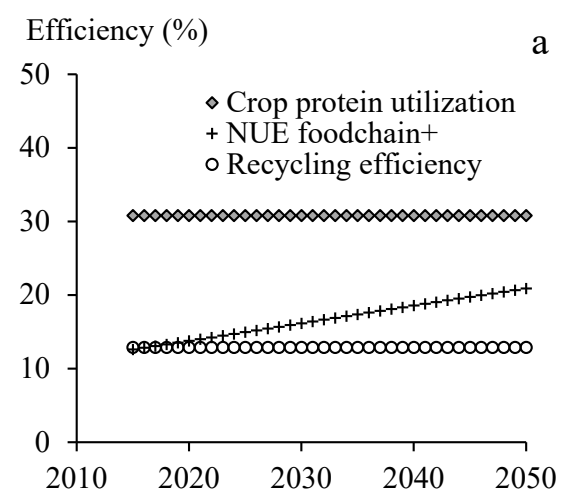

Efficiency (\%)

$\mathrm{b}$
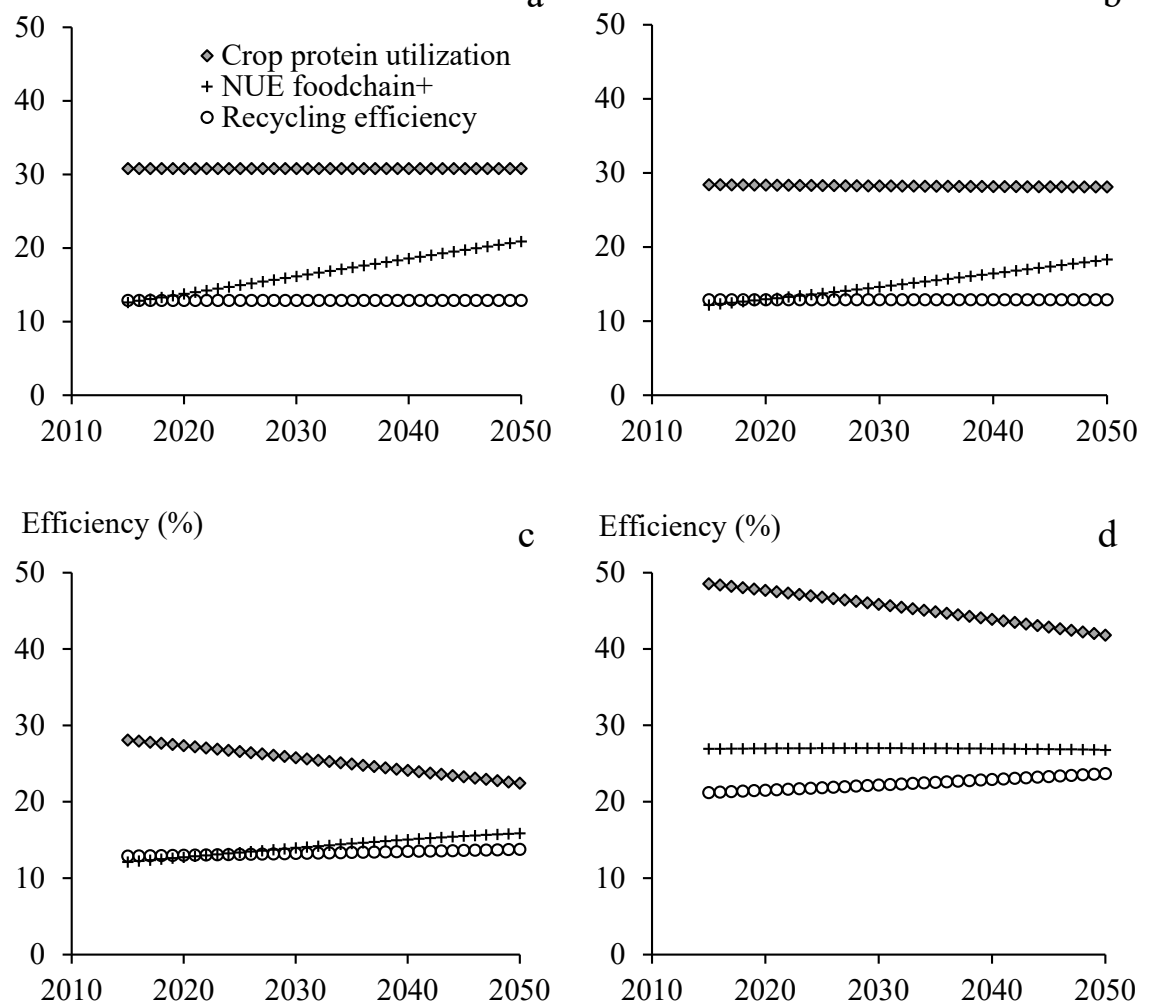

Efficiency (\%) d

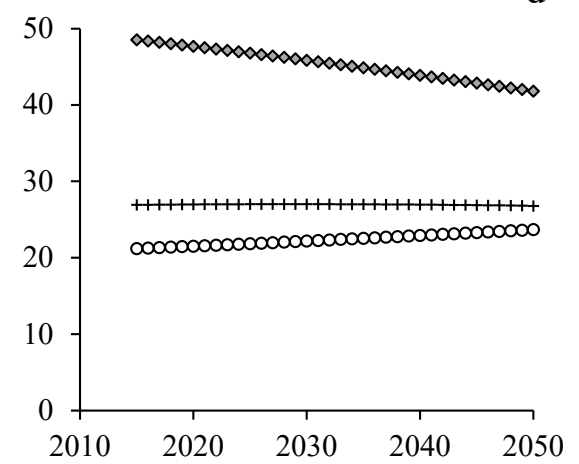

Figure 5.S2 Simulated changes in crop protein utilization (ratio of protein intake and crop protein needed for plant food and animal feed), whole food chain $\mathrm{N}$ use efficiency (ratio of protein $\mathrm{N}$ intake and 'new' $\mathrm{N}$ input needed), and recycling efficiency (the fraction of waste and manure $\mathrm{N}$ produced that is utilized as compost N) averaged over the different zones of Jimma in the period 2015 to 2050, for four scenarios: (a) BAU, (b) URBAN, (c) UPLP, and (d) TECH (see Table 5.2 for assumptions as regards scenarios). 


\section{Description and detailed results of the field experiment}

\section{Design and execution of the experiments}

The experiment was conducted at Jimma University research station for two years (2015 and 2016). The site is located at $7^{\circ} 40^{\prime} \mathrm{N}, 36^{\circ} 50^{\prime} \mathrm{E}$, at an altitude of $1780 \mathrm{~m}$.a.s.l. and $350 \mathrm{~km}$ away from Addis Ababa in Southwest Ethiopia. The annual mean rainfall is $1800-2300 \mathrm{~mm}$, of which $85 \%$ falls in June to September and the rest in January to May. The annual mean temperature is $15-22^{\circ} \mathrm{C}$. The site has a gentle slope $<5 \%$ and a well-drained Nitisol soil type. The soil has a clay loam texture ( $65 \%$ clay, $16 \%$ sand and $19 \%$ silt $)$, a $\mathrm{pH}\left(\mathrm{H}_{2} \mathrm{O}\right)$ of about 5.7 , organic matter content of $50 \mathrm{~g} \mathrm{~kg}^{-1}$, a total nitrogen content of $25 \mathrm{~g} \mathrm{~kg}^{-1}$, a P-Olsen of $4.5 \mathrm{mg} \mathrm{kg}^{-1}$, and an exchangeable $\mathrm{K}$ content of $196 \mathrm{mg} \mathrm{kg}^{-1}$ (Abebayehu et al., 2014). The site was previously cropped with maize for the study of maize resistance to stalk borer.

Table 5.S2. Chemical properties of the five composts used for the field experiments

\begin{tabular}{lcccccccc}
\hline $\begin{array}{l}\text { Type of } \\
\text { compost }\end{array}$ & pH & $\begin{array}{c}\mathrm{TC} \\
\left(\mathrm{g} \mathrm{kg}^{-1}\right)\end{array}$ & $\begin{array}{c}\mathrm{TP} \\
\left(\mathrm{g} \mathrm{kg}^{-1}\right)\end{array}$ & $\begin{array}{c}\mathrm{AP} \\
\left(\mathrm{g} \mathrm{kg}^{-1}\right)\end{array}$ & $\begin{array}{c}\mathrm{TN} \\
\left(\mathrm{g} \mathrm{kg}^{-1}\right)\end{array}$ & $\begin{array}{c}\mathrm{NH}_{4}^{+} \\
\left(\mathrm{mg} \mathrm{kg}^{-1}\right)\end{array}$ & $\begin{array}{c}\mathrm{NO}_{3}^{-} \\
\left(\mathrm{mg} \mathrm{kg}^{-1}\right)\end{array}$ & $\begin{array}{c}\mathrm{C} / \mathrm{N} \\
\text { ratio }\end{array}$ \\
\hline CMC & 6.9 & 270 & 28 & 21 & 31 & 1860 & 1240 & 8.7 \\
$\mathrm{CDC}$ & 9.0 & 308 & 16 & 12 & 26 & 1560 & 1040 & 11.8 \\
FMC & 8.8 & 256 & 13 & 10 & 18 & 1080 & 720 & 14.2 \\
KWC & 8.6 & 255 & 11 & 8 & 22 & 1320 & 880 & 11.6 \\
PMC & 7.4 & 374 & 20 & 15 & 24 & 1440 & 960 & 15.6 \\
\hline
\end{tabular}

Before the field experiment, we prepared the composts and measured their $\mathrm{N}$ and $\mathrm{P}$ contents to determine the required application rates (Komiyama et al., 2014). Urban manures (chicken manure, cattle manure (cow dung), pig manure, farm yard manure) and kitchen wastes were identified as the main organic wastes, and were collected from Jimma urban areas. Human excrements were not included because of cultural barriers. The composts (Table 5.S2) were prepared using the standard procedures (Tulema et al., 2007). Accordingly, the manures and kitchen wastes were composted in heaps (static composting) for three months, and mixed regularly. Compost maturity was assessed on the basis of the reduction in volume, $\mathrm{C} / \mathrm{N}$ ratio and $\mathrm{pH}$ value (Fischer and Glaser, 2012). The $\mathrm{C} / \mathrm{N}$ ratio of the final composts ranged from 8.7 to 15.6 (Table 5.S1). A low $\mathrm{C} / \mathrm{N}$ ratio reflects in part accumulation of mineral $\mathrm{N}$. The $\mathrm{C} / \mathrm{N}$ ratio usually decreases during the composting process due to greater carbon losses via $\mathrm{CO}_{2}$ emissions than $\mathrm{N}$ losses via $\mathrm{NH}_{3}, \mathrm{~N}_{2} \mathrm{O}$ and $\mathrm{N}_{2}$ volatilization (not measured), and stabilizes in the range of 10-15 (Bazrafshan et al., 2016).

Samples were collected from different parts of the five types of compost heaps, oven dried at $70^{\circ} \mathrm{C}$, homogenized, ground and sieved $(\leq 2 \mathrm{~mm})$ before analysis. Then, the samples were analyzed using standard laboratory procedures. Total organic $\mathrm{C}$ was determined by dichromateoxidation (Velthof et al., 1998). To determine total N (TN) and P (TP), composts samples were digested in a mixture of sulfuric and salicylic acid and Selenium (Se) to which hydrogen peroxide $\left(\mathrm{H}_{2} \mathrm{O}_{2}\right)$ was added according to the standard working instruction E1009. TN and TP 
were measured with segmented flow analyzer (SFA) using the standard working instruction E1408. TN was measured based on Berthelot reaction (measuring at $660 \mathrm{~nm}$ ), by indophenol blue method (Novozamsky et al., 1974), and TP was measured as phospho-molybdenum complex (measuring at $880 \mathrm{~nm}$ ) (Murphy and Riley, 1962). Composts were extracted with 0.01 $M \mathrm{CaCl}_{2}$ in 1:10 (mass: volume) ratio, shaken for 2 hours, centrifuged at $48,000 \mathrm{~g}$ and $\mathrm{NH}^{+}{ }_{4}$ and $\mathrm{NO}_{3}^{-}$were measured in the supernatant using the standard auto-analyzer techniques. Extractable $\mathrm{P}$ was determined by measuring orthophosphate as a phospho-molybdenum complex in $\mathrm{CaCl}_{2}$ extracts. The $\mathrm{pH}$ of composts was measured in a 1: 2.5 (weight: weight) $1 \mathrm{M}$ $\mathrm{KCl}$ extract, using digital $\mathrm{pH}$ meter (Piper, 1966). The nutrient contents of the composts (Table 5S2) were close to the values reported for chicken manure, pig manure and kitchen waste composts by others (Eckhardt et al., 2018; Huang et al., 2017; Komiyama et al., 2014; Wei et al., 2015; Yokota et al., 2003; Zamil et al., 2015).

Table 5.S3. Description of treatments used for the experiments (2015 and 2016) and their nutrient supply

\begin{tabular}{|c|c|c|c|c|}
\hline \multirow[t]{2}{*}{ № } & \multirow[t]{2}{*}{ Description of treatments } & \multicolumn{3}{|c|}{$\begin{array}{l}\text { Nutrient supply } \\
\left(\mathrm{kg} \mathrm{ha}^{-1}\right)\end{array}$} \\
\hline & & $\mathrm{N}$ & $\mathrm{P}$ & $\mathrm{K}$ \\
\hline T1 & $0 \mathrm{~kg}$ DAP $+0 \mathrm{~kg}$ UREA ha ${ }^{-1}$ & 0 & 0 & 0 \\
\hline $\mathrm{T} 2$ & $50 \mathrm{~kg}$ DAP $+50 \mathrm{~kg}$ UREA ha ${ }^{-1}$ & 32 & 11 & 0 \\
\hline T3 & $100 \mathrm{~kg}$ DAP + $100 \mathrm{~kg}$ UREA ha ${ }^{-1}$ & 64 & 21 & 0 \\
\hline T4 & $75 \mathrm{~kg}$ total nitrogen (TN) ha ${ }^{-1}$ as chicken manure compost (CMC) & 75 & 32 & 22 \\
\hline T5 & $75 \mathrm{~kg} \mathrm{TN} \mathrm{ha}^{-1}$ as cow dung (cattle manure) compost (CDC) & 75 & 12 & 18 \\
\hline T6 & $75 \mathrm{~kg} \mathrm{TN} \mathrm{ha}^{-1}$ as farm yard manure compost (FMC) & 75 & 16 & 18 \\
\hline T7 & $75 \mathrm{~kg} \mathrm{TN} \mathrm{ha}^{-1}$ as kitchen waste compost (KWC) & 75 & 15 & 23 \\
\hline T8 & $75 \mathrm{~kg}$ total $\mathrm{N} \mathrm{ha}^{-1}$ as pig manure compost (PMC) & 75 & 18 & 28 \\
\hline T9 & $150 \mathrm{~kg} \mathrm{TN} \mathrm{ha}^{-1}$ as CMC & 150 & 64 & 44 \\
\hline $\mathrm{T} 10$ & $150 \mathrm{~kg} \mathrm{TN} \mathrm{ha}^{-1}$ as CDC & 150 & 23 & 35 \\
\hline T11 & $150 \mathrm{~kg} \mathrm{TN} \mathrm{ha}^{-1}$ as FMC & 150 & 32 & 35 \\
\hline T12 & $150 \mathrm{~kg} \mathrm{TN} \mathrm{ha}^{-1}$ as KWC & 150 & 29 & 46 \\
\hline $\mathrm{T} 13$ & $150 \mathrm{~kg}$ total $\mathrm{N} \mathrm{ha}^{-1}$ as $\mathrm{PMC}$ & 150 & 35 & 55 \\
\hline
\end{tabular}

The field experiment was conducted as randomized complete block design with 13 treatments (Table 5.S3). Treatments included three references (i.e., a nil control (T1), half the recommended $\mathrm{N}$ and $\mathrm{P}$ dose (T2) and the full recommended $\mathrm{N}$ and $\mathrm{P}$ dose (T3) via DAP/UREA), and five types of composts applied at two rates (Table 5.S3).

Each treatment was replicated four times. DAP fertilizer contained $18 \% \mathrm{~N}$ and $46 \% \mathrm{P}_{2} \mathrm{O}_{5}(20 \%$ P) and UREA contained $46 \% \mathrm{~N}$. In both years, the experimental field was ploughed using oxendrawn implements and manually prepared for sowing. In July, 10 planting rows were made per plot $(4 \mathrm{~m} \times 3 \mathrm{~m})$ at $0.3 \mathrm{~m}$ row spacing, recommended for sowing of the HAR 3116 wheat variety. Composts and fertilizers were applied in rows a day before sowing. Improved wheat variety HAR 3116 (locally called Digalu) is high yielding and widely grown in the highlands of Ethiopia (Deressa et al., 2013). It has a yield potential of $4000 \mathrm{~kg} \mathrm{ha}^{-1}$ on research and $3100 \mathrm{~kg}$ $\mathrm{ha}^{-1}$ on farmers' fields (Bayeh, 2010). Seed rate was $150 \mathrm{~kg} \mathrm{ha}^{-1}$, as recommended (Mekonnen, 2017). Urea was applied in split with half at planting and the other half 42 days after planting, at tillering stage. 
In 2016, whole plant samples were collected at boot stage (stage 10 of the Feekes development scale) from 50 randomly selected plants per plot. The samples were put in an oven at $30^{\circ} \mathrm{C}$ until a constant weight was attained, ground and sieved $(\leq 2 \mathrm{~mm})$ before analysis. Samples were analyzed for total N, P and K contents, at Eurofins-Agro (http://eurofinsagro.com) using standard procedures. After wheat harvest, soil samples $(0-20 \mathrm{~cm})$ were collected from each plot randomly from six spots per plot and bulked as a composite sample per plot. Samples were oven dried at $70{ }^{\circ} \mathrm{C}$, homogenized, ground and sieved $(\leq 2 \mathrm{~mm})$ before analyses. Samples were extracted with $0.01 \mathrm{M} \mathrm{CaCl}_{2}$ in 1:10 (mass: volume) ratio and $\mathrm{N}, \mathrm{P}, \mathrm{K}$, and $\mathrm{pH}$ were determined in the extract using standard lab procedures at Eurofins-Agro (http://eurofinsagro.com).

Wheat grain and straw yields were recorded at maturity. Yield data and results of soil and plant analyses were analyzed using MonQIt (Monitoring for Quality Improvement toolbox) model. MonQIt is a toolbox that offers data processing software (www.monqit.com). MonQIt produces farm performance indicators including NPK flows, uptake and balances and gross margins (GM) per treatment (van Beek et al., 2016).

For the quantification of NPK in input and output flows, the mass of inputs (e.g. fertilizsers and the composts treatments) and outputs (wheat grain and straw yields) were multiplied by their dry matter and NPK contents (Bekunda and Manzi, 2003; Nigussie et al., 2015), (Eq. 1).

$$
F=\sum_{i=1}^{n} Q i D i C i
$$

Where, $\mathrm{F}$ is the total input or output of $\mathrm{N}$ or $\mathrm{P}$ or $\mathrm{K}$, in $\mathrm{kg}$ per ha per year; $\mathrm{n}$ is the number of different nutrient inputs and outputs in a year; $\mathrm{Q}$ is the quantity of each input or output, in $\mathrm{kg}$ per ha; $\mathrm{D}$ is the dry matter content of the inputs or outputs, in \%; $\mathrm{C}$ is the $\mathrm{N}$ or $\mathrm{P}$ or $\mathrm{K}$ contents of the inputs or outputs, in g per kg. Therefore, nutrient (NPK) balances were calculated per plot as the difference between total inputs and outputs (Eq. 2):

$$
N B=[(I N 1+\cdots+I N 4)-(O U T 1+\cdots+\text { OUT5 })]
$$

Where, NB is the nutrient balance ( $\mathrm{N}$ or $\mathrm{P}$ or $\mathrm{K}$ ); IN1 and IN2 are inputs (fertilizers and composts applied in each treatment per plot), IN3 and IN4 are atmospheric deposition and biological N fixation, respectively, and OUT1 and OUT2 are outputs (grain and straw yields obtained from each treatmet per plot) in harvested wheat and OUT3, OUT4 and OUT5 are leaching, gaseous losses and erosion, respectively (van Beek et al., 2016).

GM is an indicator of profitability, and accounts for the intrinsic values of all inputs and all outputs (Eq. 3).

$$
G M=G V-V C
$$

Where: Gross Value (GV) is the values of an output of the harvested crop and Variable Costs 
(VC) are the value of all inputs (costs of seed, labor, DAP/UREA fertilizers and composts, in Ethiopian Birr (ETB) per ha per year (1 ETB is about 0.03 Euro).

The harvest index (HI, \%) was calculated as the grain dry matter divided by the total aboveground biomass (Wang et al., 2016):

$$
H I=\frac{G D M}{T A B} * 100
$$

Where, GDM is grain dry matter $\left(\mathrm{kg} \mathrm{ha}^{-1}\right)$ and TAB is total above ground biomass $\left(\mathrm{kg} \mathrm{ha}^{-1}\right)$.

Apparent Agronomic Efficiency (AAE, $\mathrm{kg} \mathrm{kg}^{-1}$ ) of $\mathrm{N}, \mathrm{P}$ and $\mathrm{K}$ was calculated according to:

$$
A A E=\frac{Y F-Y 0}{F}
$$

Where, YF is the grain yield of a fertilized plot $\left(\mathrm{kg} \mathrm{ha}^{-1}\right)$, $\mathrm{Y} 0$ is the grain yield of the control plot $\left(\mathrm{kg} \mathrm{ha}^{-1}\right)$, and $\mathrm{F}$ is the amount of $\mathrm{N}, \mathrm{P}$ or $\mathrm{K}$ applied $\left(\mathrm{kg} \mathrm{ha}^{-1}\right)$.

Apparent N, P or K Recovery Efficiency (ARE-N, ARE-P, ARE-K, \%) was calculated as:

$$
A R E=\frac{U F-U 0}{F} * 100
$$

Where, UF is nutrient ( $\mathrm{N}, \mathrm{P}$ or K) uptake in above ground biomass of fertilized plots $\left(\mathrm{kg} \mathrm{ha}^{-1}\right)$. $\mathrm{U} 0$ is nutrient $(\mathrm{N}, \mathrm{P}$ or $\mathrm{K})$ uptake in above ground biomass of the control plot $\left(\mathrm{kg} \mathrm{ha}^{-1}\right)$, and $\mathrm{F}$ is the amount of $\mathrm{N}$ or $\mathrm{P}$ or $\mathrm{K}$ applied $\left(\mathrm{kg} \mathrm{ha}^{-1}\right)$.

Partial factor productivity (Pfp) was defined as ratio of grain yield to the sum of N, P and K applied per ha:

$$
P f p=\frac{Y F}{F(N+P+K)}
$$

The Fertilizer Replacement Value (FRV, \%) of composts was defined as the ratio of the apparent recovery efficiency (ARE) of compost treatments and the apparent recovery efficiency (ARE) of the fertilized control treatment (T3) (van Middelkoop and Holshof, 2017).

$$
F R V=\frac{A R E \text { of composts }}{\text { ARE of control treatment } T 3} * 100
$$

All data on wheat grain and straw yields, harvest index, nutrient uptake and nutrient recovery efficiencies, fertilizer replacement values and nutrient balances and GM were subjected to ANOVA. Means were compared using the LSD value at 5\% level of significance. SPSS version 23 (IBM) was used for all statistical data analyses. 


\section{Results of the experiment}

Table 5.S4 Mean nitrogen $(\mathrm{N})$, phosphorus $(\mathrm{P})$ and potassium $(\mathrm{K})$ contents in wheat plants at boot stage, in response to inorganic fertilizer (T2, T3) and composts applications (T4-T13) in 2016

\begin{tabular}{|c|c|c|c|c|c|c|}
\hline \multirow[b]{2}{*}{ Treatments } & \multicolumn{3}{|c|}{ Nutrient Supply per treatment $\left(\mathrm{kg} \mathrm{ha}^{-1}\right)$} & \multicolumn{3}{|c|}{ Nutrients in wheat plants $\left(\mathrm{g} \mathrm{kg}^{-1}\right)$} \\
\hline & $\mathrm{N}$ & $\mathrm{P}$ & $\mathrm{K}$ & $\mathrm{N}$ & $\mathrm{P}$ & $\mathrm{K}$ \\
\hline T1 & 0 & 0 & 0 & $17.3^{\mathrm{bc}}$ & $2.1^{\mathrm{f}}$ & $23.4^{b c}$ \\
\hline $\mathrm{T} 2$ & 32 & 11 & 0 & $17.8^{\mathrm{bc}}$ & $2.3^{\text {ef }}$ & $23.1^{b c}$ \\
\hline $\mathrm{T} 3$ & 64 & 21 & 0 & $16.7^{\mathrm{c}}$ & $2.5^{\text {cde }}$ & $22.6^{\mathrm{c}}$ \\
\hline T4 & 75 & 32 & 22 & $18.9^{\mathrm{ab}}$ & $2.4^{\text {de }}$ & $24.8^{\mathrm{bc}}$ \\
\hline T5 & 75 & 12 & 18 & $17.6^{\mathrm{bc}}$ & $2.3^{\mathrm{def}}$ & $23.4^{\mathrm{bc}}$ \\
\hline T6 & 75 & 16 & 18 & $17.7^{\mathrm{bc}}$ & $2.5^{\text {cde }}$ & $22.7^{\mathrm{c}}$ \\
\hline $\mathrm{T} 7$ & 75 & 15 & 23 & $16.6^{\mathrm{c}}$ & $2.3^{\text {cde }}$ & $22.6^{\mathrm{c}}$ \\
\hline $\mathrm{T} 8$ & 75 & 18 & 28 & $18.7^{\mathrm{b}}$ & $2.5^{\text {bcd }}$ & $24.0^{\mathrm{bc}}$ \\
\hline T9 & 150 & 64 & 44 & $20.5^{\mathrm{a}}$ & $2.9^{\mathrm{a}}$ & $29.5^{\mathrm{a}}$ \\
\hline $\mathrm{T} 10$ & 150 & 23 & 35 & $18.6^{\mathrm{b}}$ & $2.4^{\text {cde }}$ & $23.7^{\mathrm{bc}}$ \\
\hline T11 & 150 & 32 & 35 & $18.0^{\mathrm{bc}}$ & $2.8^{\mathrm{ab}}$ & $25.2^{b}$ \\
\hline T12 & 150 & 29 & 46 & $18.4^{\mathrm{b}}$ & $2.6^{\mathrm{bc}}$ & $24.9^{b c}$ \\
\hline T13 & 150 & 35 & 55 & $18.8^{\mathrm{b}}$ & $2.9^{\mathrm{a}}$ & $25.0^{\mathrm{bc}}$ \\
\hline$L S D$ & - & 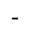 & - & 1.7 & 0.3 & 2.5 \\
\hline$P$ value & - & - & - & $* * *$ & $* * *$ & $* * *$ \\
\hline
\end{tabular}

ANOVA was used to compare treatment means. Means with different letters within columns are statistically different using LSD test at $P<0.05$. *** denotes significant difference

Nutrients (N, P and K) of wheat plants at boot stage during the second growing seasons (2016) were significantly $(P<0.05)$ affected by compost applications (Table 5.S4). Composts increased the $\mathrm{N}$ content in the plants by $2-18 \%$, the $\mathrm{P}$ content by $10-38 \%$ and the $\mathrm{K}$ content by $1.3-26 \%$ compared to the nil treatment (T1). Chicken manure compost (CMC) was most effective in enhancing the N, P and K contents at boot stage. Increased N content (22\%) was reported in wheat at boot stage from $16 \mathrm{~g} \mathrm{~kg}^{-1}$, where no manure had been added to $19.5 \mathrm{~g} \mathrm{~kg}^{-}$ ${ }^{1}$ when $150 \mathrm{~kg} \mathrm{ha}^{-1}$ organic $\mathrm{N}$ was added as manure (Rodd A. V. et al., 2002). The $\mathrm{N}$ contents of wheat plants at boot stage due to the compost treatments (Table 5S4) is close to the normal agronomic sufficiency range of 20.0-30.0 $\mathrm{g} \mathrm{kg}^{-1} \mathrm{~N}$ and the $\mathrm{P}$ and $\mathrm{K}$ contents are within the normal agronomic sufficiency range of $2.0-5.0 \mathrm{~g} \mathrm{~kg}^{-1} \mathrm{P}$ and $15.0-30.0 \mathrm{~g} \mathrm{~kg}^{-1} \mathrm{~K}$ for wheat (Rodd A. V. et al., 2002). There was a relatively large within-treatment variation in $\mathrm{N}, \mathrm{P}$ and $\mathrm{K}$ contents. In addition to the compost treatments, there was a significant block effect in $\mathrm{N}$ and $\mathrm{K}$ contents (Table 5.S5). This indicated the importance of blocking, which was likely the result of spatial variations in natural soil fertility.

Table 5.S5 Summary of significant $P$ values for nutrient content in wheat green plants (WGP) at boot stage, nutrient uptake and wheat yield across 13 treatments and 4 blocks in 2016

\begin{tabular}{llllllllll}
\hline & & \multicolumn{2}{c}{ Nutrients in WGP $\left(\mathrm{g} \mathrm{kg}^{-1}\right)$} & \multicolumn{2}{c}{ Nutrient uptake $\left(\mathrm{kg} \mathrm{ha}^{-1}\right)$} & \multicolumn{2}{c}{ Wheat yield $\left(\mathrm{kg} \mathrm{h}^{-1}\right)$} \\
\cline { 3 - 9 } Source & $\mathrm{N}$ & $\mathrm{P}$ & $\mathrm{K}$ & $\mathrm{N}$ & $\mathrm{P}$ & $\mathrm{K}$ & Grain & Straw \\
\hline Block & 3 & 0.0001 & 0.1397 & 0.0001 & 0.0097 & 0.0089 & 0.0088 & 0.0088 & 0.0177 \\
Treatment & 12 & 0.0031 & 0.0001 & 0.0002 & 0.0001 & 0.0002 & 0.0002 & 0.0005 & 0.0002 \\
\hline \multicolumn{3}{l}{ ANOVA was used to compare 13 treatments replicted in 4 blocks using LSD test at $P<0.05$}
\end{tabular}


Grain and straw yields and $\mathrm{N}$ uptake of wheat were significantly $(P<0.05)$ affected by compost applications (Table 5.S6). Compost applications (T4-T13) increased grain yield by $45-248 \%$ and straw yield by 36-297\% over the nil treatment (T1). Compost applications increased N uptake by $42-287 \%$, P uptake by $40-240 \%$, and $\mathrm{K}$ uptake by $40-260 \%$ compared to the nil treatment. Only chicken manure compost (T9) increased the N uptake, P uptake, and K uptake as well as the grain and straw yields of wheat, relative to the reference treatment T3. There was significant block effect on $\mathrm{N}, \mathrm{P}$ and $\mathrm{K}$ uptake and on grain and straw yields of wheat.

Table 5.S6 Wheat grain and straw nutrient uptake, yields and harvest index in response to urban manures and kitchen waste composts and inorganic fertilizer treatments in 2015

\begin{tabular}{|c|c|c|c|c|c|c|}
\hline \multirow[b]{2}{*}{ Treatments } & \multicolumn{3}{|c|}{ Nutrient uptake $\left(\mathrm{kg} \mathrm{ha}^{-1}\right)$} & \multicolumn{2}{|c|}{ Wheat yield $\left(\mathrm{kg} \mathrm{ha}^{-1}\right)$} & \multirow{2}{*}{$\begin{array}{l}\text { Harvest index } \\
\text { (HI) }(\%)\end{array}$} \\
\hline & $\mathrm{N}$ & $\mathrm{P}$ & $\mathrm{K}$ & Grain & Straw & \\
\hline $\mathrm{T} 1$ & $33^{\mathrm{e}}$ & $5^{\mathrm{e}}$ & $5^{\mathrm{e}}$ & $1125^{\mathrm{e}}$ & $1825^{\mathrm{e}}$ & $38^{\mathrm{a}}$ \\
\hline $\mathrm{T} 2$ & $51^{\mathrm{de}}$ & $7^{\mathrm{de}}$ & $8^{\text {de }}$ & $1650^{\text {cde }}$ & $3075^{\text {cde }}$ & $34^{\mathrm{a}}$ \\
\hline $\mathrm{T} 3$ & $84^{\text {bc }}$ & $12^{\mathrm{bc}}$ & $13^{\mathrm{bc}}$ & $2685^{\mathrm{bc}}$ & $5100^{\mathrm{bc}}$ & $34^{\mathrm{a}}$ \\
\hline $\mathrm{T} 4$ & $73^{\text {bcd }}$ & $11^{\text {bcd }}$ & $11^{\mathrm{bcd}}$ & $2488^{\text {bcd }}$ & $4175^{\mathrm{cd}}$ & $36^{\mathrm{a}}$ \\
\hline T5 & $53^{\text {cde }}$ & $8^{\text {cde }}$ & $8^{\text {cde }}$ & $1773^{\text {cde }}$ & $3100^{\text {cde }}$ & $37^{\mathrm{a}}$ \\
\hline T6 & $53^{\text {cde }}$ & $8^{\text {cde }}$ & $8^{\text {cde }}$ & $1830^{\text {cde }}$ & $2950^{\mathrm{de}}$ & $38^{\mathrm{a}}$ \\
\hline $\mathrm{T} 7$ & $55^{\text {cde }}$ & $8^{\text {cde }}$ & $8^{\text {cde }}$ & $1875^{\text {cde }}$ & $3075^{\text {cde }}$ & $36^{\mathrm{a}}$ \\
\hline $\mathrm{T} 8$ & $67^{\mathrm{cd}}$ & $10^{\mathrm{cd}}$ & $10^{\mathrm{cd}}$ & $2208^{\mathrm{cd}}$ & $3975^{\mathrm{cd}}$ & $35^{\mathrm{a}}$ \\
\hline T9 & $121^{\mathrm{a}}$ & $17^{\mathrm{a}}$ & $18^{\mathrm{a}}$ & $3920^{\mathrm{a}}$ & $7250^{\mathrm{a}}$ & $35^{\mathrm{a}}$ \\
\hline $\mathrm{T} 10$ & $46^{\mathrm{de}}$ & $7^{\mathrm{de}}$ & $7^{\mathrm{de}}$ & $1628^{\mathrm{de}}$ & $2475^{\mathrm{de}}$ & $40^{\mathrm{a}}$ \\
\hline $\mathrm{T} 11$ & $68^{\mathrm{cd}}$ & $9^{\mathrm{cd}}$ & $10^{\mathrm{cd}}$ & $2100^{\text {cde }}$ & $4250^{\text {bcd }}$ & $36^{\mathrm{a}}$ \\
\hline T12 & $74^{\text {bcd }}$ & $11^{\mathrm{bcd}}$ & $11^{\text {bcd }}$ & $2493^{\text {bcd }}$ & $4325^{\text {bcd }}$ & $35^{\mathrm{a}}$ \\
\hline $\mathrm{T} 13$ & $102^{\mathrm{ab}}$ & $14^{\mathrm{ab}}$ & $15^{\mathrm{ab}}$ & $3278^{\mathrm{ab}}$ & $6250^{\mathrm{ab}}$ & $35^{\mathrm{a}}$ \\
\hline$L S D$ & 32 & 4 & 3 & 1056 & 2061 & 7 \\
\hline Pvalue & $* * *$ & $* * *$ & $* * *$ & $* * *$ & $* * *$ & NS \\
\hline
\end{tabular}

ANOVA was used to compare treatment means. Means with different letters within columns are statistically different using LSD test at $P<0.05$. *** denotes a significant difference, and NS denotes a non-significant difference between means.

Nutrient balances and nutrient use efficiencies were significantly affected by compost and fertilizer applications (Table 5.S7). Compost applications reversed the negative $\mathrm{N}$ and $\mathrm{K}$ balances under T1-T3 to positive $\mathrm{N}$ and $\mathrm{K}$ balances. The apparent agronomic efficiency (AAE) was on average lower in compost treatments (T4-T13) than in the DAP+UREA reference treatments $\mathrm{T} 2$ and $\mathrm{T} 3$, for both $\mathrm{N}$ and $\mathrm{P}$. The apparent recovery (ARE) was on average also lower in compost treatments (T4-T13) than in the DAP+UREA reference treatments $\mathrm{T} 2$ and $\mathrm{T} 3$, especially for $\mathrm{N}$.

The partial factor productivity (Pfp) was also lower in compost treatments (T4-T13) than in the DAP+UREA reference treatments, indicating that the composts were less effective in enhancing grain yield than the inorganic fertilizers, per applied nutrients. The fertilizer replacement value (FRV) of composts was on average only half of that of DAP+UREA for N but two times for $\mathrm{P}$ (Table 5.S7). Chicken manure compost (CMC) had a relatively high and cow dung (CDC) a relatively low FRV-N. Pig manure compost (PMC) had a relatively high and CMC a relatively low FRV-P. 
Table 5.S7 Partial nutrient balances, apparent agronomic efficiency (AAE), apparent recovery efficiency (ARE), partial factor productivity (PFP), and fertilizer replacement values (FRV) of inorganic fertilizers (T2, T3) and compost (T4-T13) applications in 2015

\begin{tabular}{|c|c|c|c|c|c|c|c|c|c|c|c|c|c|}
\hline \multirow{3}{*}{ 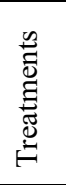 } & \multirow{2}{*}{\multicolumn{3}{|c|}{$\begin{array}{l}\text { Partial nutrient } \\
\text { Balances } \\
\left(\mathrm{kg} \mathrm{ha}^{-1}\right)\end{array}$}} & \multicolumn{7}{|c|}{ Nutrient Use Efficiency indices ${ }^{a}$} & \multirow{2}{*}{\multicolumn{3}{|c|}{$\operatorname{FRV}(\%)^{b}$}} \\
\hline & & & & \multicolumn{3}{|c|}{$\begin{array}{l}\mathrm{AAE} \\
\left(\mathrm{kg} \text { grain } \mathrm{kg}^{-1}\right. \\
\mathrm{N} \text { or } \mathrm{P} \text { or K) }\end{array}$} & \multicolumn{3}{|c|}{$\begin{array}{l}\text { ARE } \\
(\%)\end{array}$} & \multirow{2}{*}{$\begin{array}{l}\mathrm{PFP} \\
\left(\mathrm{kg} \text { grain } \mathrm{kg}^{-1}\right. \\
\mathrm{N}+\mathrm{P}+\mathrm{K} \\
\text { applied) }\end{array}$} & & & \\
\hline & $\mathrm{N}$ & $\mathrm{P}$ & $\mathrm{K}$ & $\mathrm{N}$ & $P$ & $\mathrm{~K}$ & $\mathrm{~N}$ & $\mathrm{P}$ & $\mathrm{K}$ & & $\mathrm{N}$ & $P$ & $\mathrm{~K}$ \\
\hline T1 & -33 & -5 & -5 & $\mathrm{na}^{\mathrm{c}}$ & na & na & na & na & na & $\mathrm{Na}$ & na & na & na \\
\hline $\mathrm{T} 2$ & -19 & 4 & -8 & 16 & 48 & na & 56 & 18 & na & 38 & na & na & na \\
\hline $\mathrm{T} 3$ & -20 & 9 & -13 & 24 & 74 & na & 80 & 33 & na & 32 & na & na & na \\
\hline $\mathrm{T} 4$ & 2 & 21 & 11 & 18 & 43 & 62 & 53 & 19 & 27 & 19 & 67 & 57 & na \\
\hline T5 & 22 & 4 & 10 & 9 & 54 & 36 & 27 & 25 & 17 & 17 & 33 & 76 & na \\
\hline T6 & 22 & 8 & 10 & 9 & 44 & 39 & 27 & 19 & 17 & 17 & 33 & 57 & na \\
\hline $\mathrm{T} 7$ & 20 & 7 & 15 & 10 & 50 & 33 & 29 & 20 & 13 & 17 & 37 & 61 & na \\
\hline $\mathrm{T} 8$ & 8 & 8 & 18 & 14 & 60 & 39 & 45 & 28 & 18 & 18 & 57 & 84 & na \\
\hline T9 & 29 & 47 & 26 & 19 & 44 & 64 & 59 & 19 & 30 & 15 & 73 & 57 & na \\
\hline $\mathrm{T} 10$ & 104 & 16 & 28 & 3 & 22 & 14 & 9 & 9 & 6 & 8 & 11 & 26 & na \\
\hline $\mathrm{T} 11$ & 82 & 23 & 25 & 7 & 30 & 28 & 23 & 13 & 14 & 10 & 29 & 38 & na \\
\hline $\mathrm{T} 12$ & 76 & 18 & 35 & 9 & 47 & 30 & 27 & 21 & 13 & 11 & 34 & 63 & na \\
\hline $\mathrm{T} 13$ & 48 & 21 & 40 & 14 & 62 & 39 & 46 & 26 & 18 & 14 & 58 & 78 & na \\
\hline
\end{tabular}

${ }^{\mathrm{a}}$ See equation 2,3 and $4,{ }^{\mathrm{b}}$ See equation $5,{ }^{\mathrm{c}}$ na $=$ not applicable

Gross margin $(\mathrm{GM})$ was significantly $(P<0.05)$ affected by the compost treatments (Figure 5.S3). Compost treatments T3, T4, T9 and T13 increased the GM compared to the control treatment (T1). However, there were no statistically significant differences for the other compost treatments, indicating that compost application was only marginally profitable.

\section{GM (1000 ETB)}

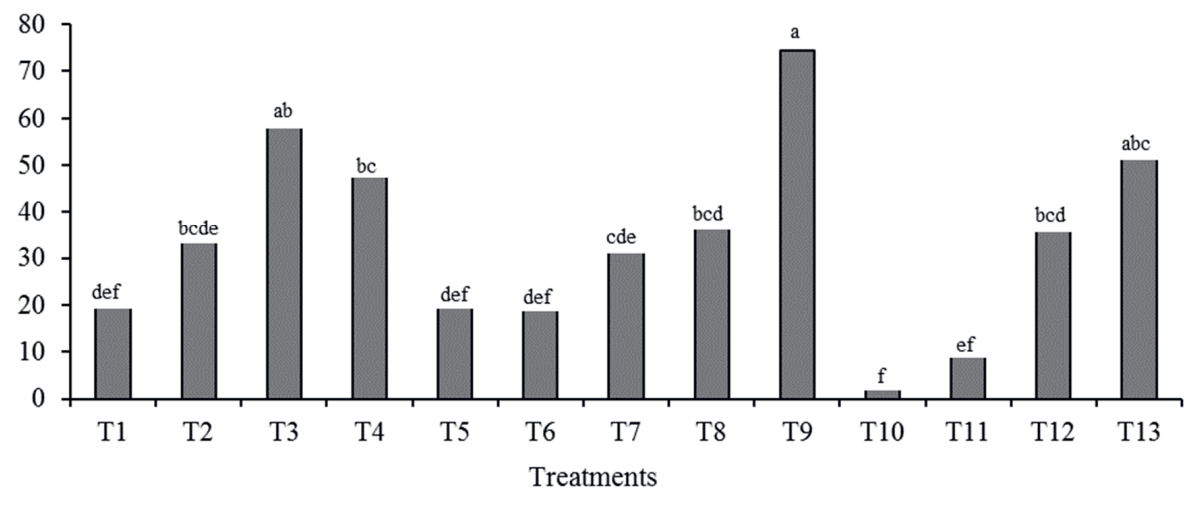

Figure 5.S3 Gross margin as affected by compost (T4-T13) and DAP+UREA fertilizer (T1-T3) applications. Data for 2015. 


\section{Discussion of the results of the field experiment}

Grain and straw yields of the control treatment were low, indicating that the site has low inherent soil fertility. Grain yields were lower than straw yield, across all compost treatments (Figure 5.S4). The DAP-UREA fertilizer combinations applied at recommended rates more than doubled the grain and straw yields of the control (Table 5.S6) and increased the $\mathrm{N}$ and $\mathrm{P}$ contents of the above ground biomass at booting stage (Table 5.S4), which indicates that the soil was responsive to $\mathrm{N}$ and/or $\mathrm{P}$ applications. An increase in crop performances following fertilizer use could be attributed to the low inherent soil fertility of the experimental plots that leads to positive responses following N, P and/or K applications (Fatondji and Ibrahim, 2018). The apparent agronomic efficiency to fertilizer $\mathrm{N}$ (AAE-N) ranged from 16 to $24 \mathrm{~kg} \mathrm{~kg}^{-1}$, is modest (Ladha et al., 2005). The apparent agronomic efficiency to fertilizer P (AAE-P) ranged

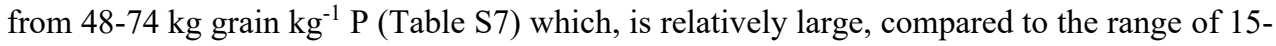
$40 \mathrm{~kg}_{\text {grain }} \mathrm{kg}^{-1} \mathrm{P}$ for cereals (mainly, maize, rice, and wheat) (Fixen P. et al., 2015). Compost applications also increased the grain and straw yields compared to the nil control treatment (Table 5.S6) and the $\mathrm{N}$ and $\mathrm{P}$ contents of the aboveground biomass at booting stage. The yield responses to compost applications were variable but roughly of the same order of magnitude as the responses to DAP-UREA applications (Table 5.S6). The variable response is related to the variability within treatments, which were the result of small-scale spatial variations in soil fertility and the heterogeneity of the composts. The small-scale spatial variations in soil fertility were probably exaggerated by the relative drought during the growing season; rainfall during the growing season was $230 \mathrm{~mm}$ below average. As a result, maximum grain yields were less than the potential attainable grain yield of $4000 \mathrm{~kg} \mathrm{ha}^{-1}$ (Bayeh, 2010). Wheat yield responses to compost applications may be attributed to the $\mathrm{N}$ and $\mathrm{P}$ in the applied composts, although only a fraction of the $\mathrm{N}$ and $\mathrm{P}$ in composts was readily available $\mathrm{N}$ and $\mathrm{P}$ (Table 5.S2). The composts also supplied organic matter, potassium (K) and very likely other essential (micro) nutrients to the soil, which may have been beneficial to the wheat crop (Chen et al., 2018). Chicken manure compost gave the highest average yield response (Table 5.S6). This may be related to its relatively high $\mathrm{N}$ and $\mathrm{P}$ contents (Table S2) but also to the acid-neutralizing capacity of chicken manure.

Chicken manure commonly has relatively high calcium $(\mathrm{Ca})$ and magnesium $(\mathrm{Mg})$ contents (Ksheem et al., 2015), which acts as lime (Fernandes et al., 2018). Cow dung gave the lowest yield, which is congruent to its relatively low $\mathrm{N}$ and $\mathrm{P}$ contents (Table 5.S2), but also due to its relatively low acid-neutralizing capacity. Higher $\mathrm{N}$ and $\mathrm{P}$ in dried chicken manure than in dried cow dung was reported (Webb et al., 2013). Likewise, there is a report that higher P, K, Ca and $\mathrm{Mg}$ contents in chicken manure compost than in cow dung compost (Faridullah et al., 2018). The mean apparent agronomic efficiency (AAE) ranged from 5 to $20 \mathrm{~kg}$ grain per $\mathrm{kg}$ for N, from 35 to 65 for P and from 25 to 65 for K (Table S7; Figure 5.S5).

Compost applications had a positive effect on N, P and K balances (Table 5.S7), indicating that the recycling of composts, derived from urban livestock manures and kitchen wastes, may reverse current practices of soil mining in rural areas. 


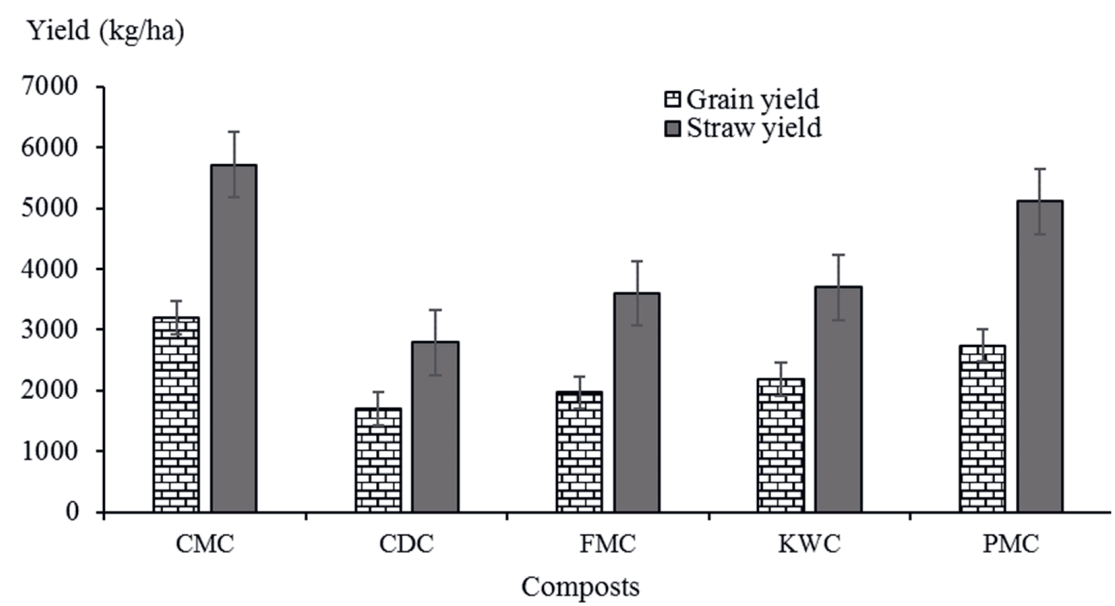

Figure 5.S4 Mean grain and straw yields of compost treatments (means of two applications doses).

Recycling of manures and wastes from urban areas in rural areas will decrease the environmental burden of current dumping and discharge practices in urban areas, increase crop yields, stop soil nutrient depletion, save synthetic fertilizers, and improve soil fertility in rural areas at the same time (Tadesse et al., 2018). The use of agricultural wastes reduced depletion rates of soil N, reversed the soil $\mathrm{P}$ balance and brought a positive outcome (Krause and Rotter, 2018). Higher plant $P$ and $K$ contents was reported in treatments with organic fertilizers than in treatments with inorganic $\mathrm{N}$ fertilizers, likely because the organic fertilizers supplied also $\mathrm{P}$ and $\mathrm{K}$, and because the organic fertilizers may have increased soil organic carbon content, cation exchange capacity (CEC), and $\mathrm{pH}$ (Agegnehu and Amede, 2017). There is an argument that crop responses to manure applications depend on the availability of $\mathrm{N}$, and hence on the quality of the manure (Rufino et al., 2006). It is stated that the $\mathrm{N}$ and $\mathrm{P}$ availability in manure depends on the organic matter content of the manure, because mineralization is a major biochemical pathway through which organically bound $\mathrm{N}$ and $\mathrm{P}$ become plant available (Chen et al., 2018). It is also indicated that manure application influenced soil organic matter content and P Olsen (Chen et al., 2018). Surprisingly, they reported the greatest yield benefit of organic amendments in soils with neutral $\mathrm{pH}$ values (6.6-7.3), suggesting that the liming effect of organic amendments is not much beneficial.

The mean apparent recovery efficiencies (ARE) of applied compost nutrients ranged from 15 to $60 \%$ for N, from 15 to $30 \%$ for P, and from 10 to 30 for K (Fig. S6). Clearly, CMC and PMC had the highest mean ARE-N, and CDC and FMC had the lowest mean ARE-N. The cow dung compost (CDC) had also a low ARE-P and ARE-K (Fig. S6). Other researcher (Roberts, 2008) also reported the highest nutrient use efficiency at the lower part of the yield response curve. 


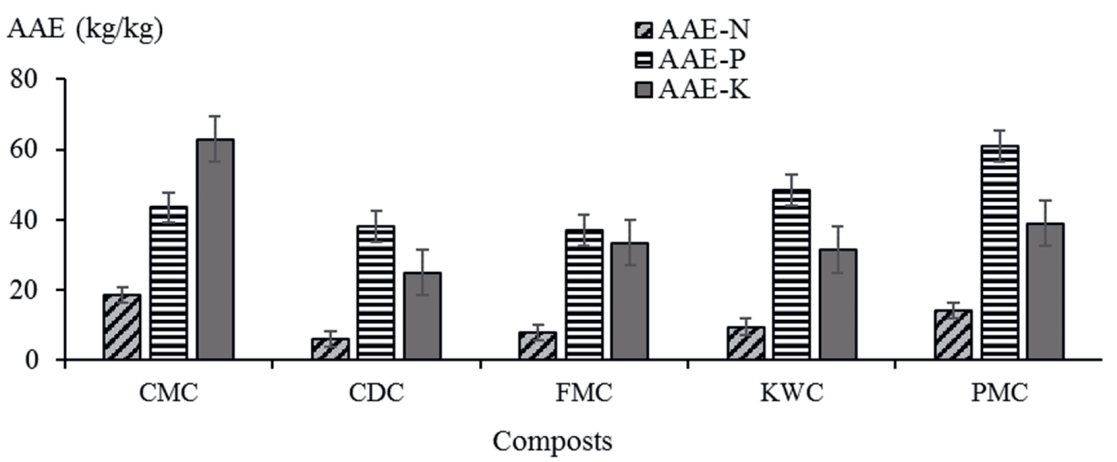

Figure 5.S5 Mean apparent agronomic efficiencies (AAE) of applied nitrogen $(\mathrm{N})$, phosphorus $(\mathrm{P})$ and potassium (K) via composts (means of two application doses).

Results of our experiment do not (yet) show clear indications of 'diminishing returns' of the high compost application rates (Table 5.S6); this allowed us to average the results of the two compost application rates. A recent review of worldwide data on $\mathrm{N}$ use efficiency for cereal crops reported a mean fertilizer $\mathrm{N}$ recovery efficiency of $57 \%$ for wheat and a mean fertilizer nutrient efficiency of about $50 \%$ for N, 10\% for P, and $40 \%$ for K (Baligar et al., 2007). These studies dealt with single-nutrient, synthetic and soluble fertilizers. In contrast, compost contains multi-nutrients, which are partly organically bound and only become available following mineralization. As a result, the recovery efficiencies of nutrients from composts cannot be estimated easily and accurately. It has been indicated that only $20 \%$ of the $\mathrm{N}$ in composted manure would become plant available in the $1^{\text {st }}, 20 \%$ in the $2^{\text {nd }}, 10 \%$ in the $3^{\text {rd }}$ and $5 \%$ in the $4^{\text {th }}$ year after application (Horrocks et al., 2016). Thus, the resulting efficiencies are often relatively low, especially in the year of application. Similarly, it was reported that solid manures release relatively little $\mathrm{N}$ during the season after application, and that there is a huge variation between different types of manures (Webb et al., 2013).

The nutrient supply from organic amendments to crops is commonly expressed in the so-called Fertilizer Replacement Value (FRV), which can be determined by comparing the nutrient uptake in composts amended plots against mineral fertilizer-only plots. A proper comparison per nutrient element requires that other essential nutrients are not limiting crop yield and nutrient uptake, following the ceteris paribus principle (Hijbeek et al., 2017).

The apparent FRV-N and FRV-P of our compost treatments (T4-T13) ranged from 11 to 73\% and from 26 to $78 \%$, respectively, and were related to compost type and application rate (Table 5.S6). According to other researchers (Hijbeek et al., 2017), FRV-N of FYM and other types of organic amendments was higher at high $\mathrm{N}$ supply than at low $\mathrm{N}$ supply. In contrast, we observed that type of compost was more important than the rate of application in determining the FRV of composts (Table 5.S7). 


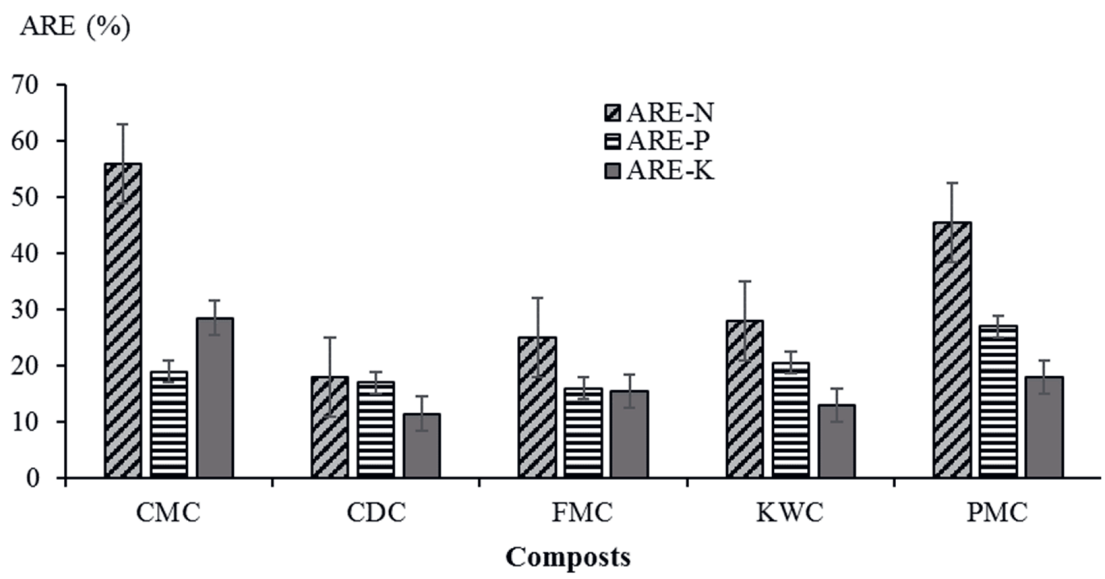

Figure 5.S6 Mean apparent recovery efficiencies (ARE) of applied nitrogen (N), phosphorus (P) and potassium $(\mathrm{K})$ via composts (means of two applications doses). 


\section{References:}

Abebayehu A., Misginaw T., Abraham B., Solomon T., Alemayehu R., Bayu D. (2014) Influences of mineral nitrogen and phosphorous fertilization on yield and yield contributing components in hot pepper (Capsicum annuum L.). African Journal of Agricultural Research 9:670-675. DOI: 10.5897/ajar2013.8262.

Abrha C., Feyisa G.L., Feyssa D.H. (2015) Analysis of land use/cover dynamics in Jimma city, Southwest Ethiopia: an application of satellite remote sensing. Ethiop.J.Appl.Sci. Technol. 6:24-34.

Agegnehu G., Amede T. (2017) Integrated Soil Fertility and Plant Nutrient Management in Tropical Agro-Ecosystems: A Review. Pedosphere 27:662-680. DOI: 10.1016/s10020160(17)60382-5.

Alexander P., Brown C., Arneth A., Finnigan J., Moran D., Rounsevell M.D.A. (2017) Losses, inefficiencies and waste in the global food system. Agric Syst 153:190-200. DOI: 10.1016/j.agsy.2017.01.014.

Arndt C., Powell J.M., Aguerre M.J., Crump P.M., Wattiaux M.A. (2015) Feed conversion efficiency in dairy cows: Repeatability, variation in digestion and metabolism of energy and nitrogen, and ruminal methanogens. J Dairy Sci 98:3938-50. DOI: 10.3168/jds.2014-8449.

Ayele Z., Peacock C. (2003) Improving access to and consumption of animal source foods in rural households: the experiences of a women-focused goat development program in the highlands of Ethiopia. J Nutr 133:3981S-3986S. DOI: 10.1093/jn/133.11.3981S.

Bai Z., Ma W., Ma L., Velthof G.L., Wei Z., Havlík P., Oenema O., Lee M.R.F., Zhang F. (2018) China's livestock transition: Driving forces, impacts, and consequences. . Science Advances 4:eaar8534.

Baligar V.C., Fageria N.K., He Z.L. (2007) Nutrient Use Efficiency in Plants. Communications in Soil Science and Plant Analysis 32:921-950. DOI: 10.1081/css-100104098.

Bayeh B. (2010) Assessment of Bread Wheat Production, Marketing and Selection of NEfficient Bread Wheat (Triticum aestivum L.) Varieties for Higher Grain Yield and Quality in North Western Ethiopia, Department of Plant Sciences, Bahir Dar University, Bahir Dar pp. 102.

Bazrafshan E., Zarei A., Kord Mostafapour F., Poormollae N., Mahmoodi S., Zazouli M.A. (2016) Maturity and Stability Evaluation of Composted Municipal Solid Wastes. Health Scope 5. DOI: 10.17795/jhealthscope-33202.

Bekunda M., Manzi G. (2003) Use of the partial nutrient budget as an indicator of nutrient depletion in the highlands of southwestern Uganda. Nutrient Cycling in Agroecosystems 67:187-195.

Bittman S., Dedina M., Howard C.M., Oenema O., Sutton M.A. (2014) Options for Ammonia Mitigation: Guidance from the UNECE Task Force on Reactive Nitrogen. Centre for Ecology and Hydrology, Edinburgh.

Chen X., Cui Z., Fan M., Vitousek P., Zhao M., Ma W., Wang Z., Zhang W., Yan X., Yang J., Deng X., Gao Q., Zhang Q., Guo S., Ren J., Li S., Ye Y., Wang Z., Huang J., Tang Q., Sun Y., Peng X., Zhang J., He M., Zhu Y., Xue J., Wang G., Wu L., An N., Wu L., Ma L., Zhang W., Zhang F. (2014) Producing more grain with lower environmental costs. Nature 514:486-9. DOI: 10.1038/nature13609.

Chen X.P., Cui Z.L., Vitousek P.M., Cassman K.G., Matson P.A., Bai J.S., Meng Q.F., Hou P., Yue S.C., Romheld V., Zhang F.S. (2011) Integrated soil-crop system management for food security. Proc Natl Acad Sci U S A 108:6399-404. DOI: 10.1073/pnas.1101419108. 
Chen Y., Camps-Arbestain M., Shen Q., Singh B., Cayuela M.L. (2018) The long-term role of organic amendments in building soil nutrient fertility: a meta-analysis and review. Nutrient Cycling in Agroecosystems 111:103-125. DOI: 10.1007/s10705-017-9903-5.

Cochrane L., Bekele Y.W. (2018) Average crop yield (2001-2017) in Ethiopia: Trends at national, regional and zonal levels. Data Brief 16:1025-1033. DOI: 10.1016/j.dib.2017.12.039.

Connor D.J., Loomis R.S., Cassman K.G. (2011) Crop Ecology. Productivity and management in agricultural systems. Cambridge Univ. Press, Cambridge, UK.

Cui Z., Zhang H., Chen X., Zhang C., Ma W., Huang C., Zhang W., Mi G., Miao Y., Li X., Gao Q., Yang J., Wang Z., Ye Y., Guo S., Lu J., Huang J., Lv S., Sun Y., Liu Y., Peng X., Ren J., Li S., Deng X., Shi X., Zhang Q., Yang Z., Tang L., Wei C., Jia L., Zhang J., He M., Tong Y., Tang Q., Zhong X., Liu Z., Cao N., Kou C., Ying H., Yin Y., Jiao X., Zhang Q., Fan M., Jiang R., Zhang F., Dou Z. (2018) Pursuing sustainable productivity with millions of smallholder farmers. Nature 555:363-366. DOI: 10.1038/nature25785.

de Bruyn J., Ferguson E., Allman-Farinelli M., Darnton-Hill I., Maulaga W., Msuya J., Alders R. (2016) Food composition tables in resource-poor settings: exploring current limitations and opportunities, with a focus on animal-source foods in sub-Saharan Africa. Br J Nutr:1-11. DOI: 10.1017/S0007114516003706.

Deressa H., Dechassa N., Ketema M., Amanu T. (2013) Farmer Participatory Evaluation of Agronomic Performances of Bread Wheat Varieties in the Highlands of Eastern Ethiopia. East African Journal of Sciences 7:121-128.

Dorris C. (2020) Changes of Food System and Nitrogen Flow in Kenya. MSc Thesis University of Chinese Academy of Sciences. Centre for Agricultural Resources Research Institute of Genetics and Developmental Biology. Chinese Academy of Science. pp. 72.

Eckhardt D.P., Redin M., Santana N.A., Conti L.D., Dominguez J., Jacques R.J.S., Antoniolli Z.I. (2018) Cattle Manure Bioconversion Effect on the Availability of Nitrogen, Phosphorus, and Potassium in Soil. Revista Brasileira de Ciência do Solo 42. DOI: 10.1590/18069657rbcs20170327.

Enahoro D., Lannerstad M., Pfeifer C., Dominguez-Salas P. (2018) Contributions of livestockderived foods to nutrient supply under changing demand in low- and middle-income countries. Global Food Security 19:1-10. DOI: 10.1016/j.gfs.2018.08.002.

FAOSTAT. (2020) Cereals production indices. http://www.fao.org/faostat/en/\#country/238. (Data retrieved in May/June and in November 2020).

Faridullah F., Hafeez S., Ahmed T., Alam S., Naz A., Shah W., Khalid S. (2018) Characterization of Phosphorus in Fresh and Composted Manures of Different Livestock. Polish Journal of Environmental Studies 27:615-622. DOI: $10.15244 /$ pjoes $/ 68883$.

Fatondji D., Ibrahim A. (2018) Improving nutrient use efficiency from decomposing manure and millet yield under Plinthosols in Niger. Nutrient Cycling in Agroecosystems 110:485-499. DOI: 10.1007/s10705-018-9910-1.

Fernandes J.D., Chaves L.H.G., Mendes J.d.S., Chaves I.d.B., Tito G.A. (2018) Soil Chemical Amendments and the Macronutrients Mobility Evaluation in Oxisol Treated With Biochar. Journal of Agricultural Science 10. DOI: 10.5539/jas.v10n10p238.

Fischer D., Glaser B. (2012) Synergisms between Compost and Biochar for Sustainable Soil Amelioration, Management of Organic Waste.

Fixen P., Brentrup F., Norton R., Bruulsema T., Garcia F., Zingore S. (2015) Nutrient/fertilizer use efficiency: measurement, current situation and trends. 
Ghosh P.R., Fawcett D., Sharma S.B., Poinern G.E. (2016) Progress towards Sustainable Utilisation and Management of Food Wastes in the Global Economy. Int J Food Sci 2016:3563478. DOI: $10.1155 / 2016 / 3563478$.

Gietel-Basten S., Han X., Cheng Y. (2019) Assessing the impact of the "one-child policy" in China: A synthetic control approach. PLoS One 14:e0220170. DOI: 10.1371/journal.pone.0220170.

Hijbeek R., ten Berge H.F.M., Whitmore A.P., Barkusky D., Schröder J.J., van Ittersum M.K. (2017) Nitrogen fertiliser replacement values for organic amendments appear to increase with $\mathrm{N}$ application rates. Nutrient Cycling in Agroecosystems 110:105-115. DOI: $10.1007 / \mathrm{s} 10705-017-9875-5$.

Horrocks A., Curtin D., Tregurtha C., Meenken E. (2016) Municipal Compost as a Nutrient Source for Organic Crop Production in New Zealand. Agronomy 6. DOI: 10.3390/agronomy6020035.

Hou Y., Ma L., Sárdi K., Sisák I., Ma W. (2015) Nitrogen flows in the food production chain of Hungary over the period 1961-2010. Nutrient Cycling in Agroecosystems 102:335346. DOI: $10.1007 / \mathrm{s} 10705-015-9703-8$.

Huang J., Yu Z., Gao H., Yan X., Chang J., Wang C., Hu J., Zhang L. (2017) Chemical structures and characteristics of animal manures and composts during composting and assessment of maturity indices. PLoS One 12:e0178110. DOI: 10.1371/journal.pone.0178110.

Komiyama T., Ito T., Saigusa M. (2014) Effects of phosphorus-based application of animal manure compost on the yield of silage corn and on soil phosphorus accumulation in an upland Andosol in Japan. Soil Science and Plant Nutrition 60:863-873. DOI: $10.1080 / 00380768.2014 .955449$.

Krause A., Rotter V. (2018) Recycling Improves Soil Fertility Management in Smallholdings in Tanzania. Agriculture 8. DOI: 10.3390/agriculture8030031.

Ksheem A.M., Bennett J.M., Antille D.L., Raine S.R. (2015) Towards a method for optimized extraction of soluble nutrients from fresh and composted chicken manures. Waste Manag 45:76-90. DOI: 10.1016/j.wasman.2015.02.011.

Ladha J.K., Pathak H., J. Krupnik T., Six J., van Kessel C. (2005) Efficiency of Fertilizer Nitrogen in Cereal Production: Retrospects and Prospects, Advances in Agronomy Volume 87. pp. 85-156.

Ma L., Guo J., Velthof G.L., Li Y., Chen Q., Ma W., Oenema O., Zhang F. (2014) Impacts of urban expansion on nitrogen and phosphorus flows in the food system of Beijing from 1978 to 2008. Global Environmental Change 28:192-204. DOI: 10.1016/j.gloenvcha.2014.06.015.

Ma L., Ma W.Q., Velthof G.L., Wang F.H., Qin W., Zhang F.S., Oenema O. (2010) Modeling nutrient flows in the food chain of China. J Environ Qual 39:1279-89. DOI: 10.2134 /jeq2009.0403.

Ma L., Velthof G.L., Wang F.H., Qin W., Zhang W.F., Liu Z., Zhang Y., Wei J., Lesschen J.P., Ma W.Q., Oenema O., Zhang F.S. (2012) Nitrogen and phosphorus use efficiencies and losses in the food chain in China at regional scales in 1980 and 2005. Science of The Total Environment 434:51-61. DOI: https://doi.org/10.1016/j.scitotenv.2012.03.028.

Ma L., Wang F., Zhang W., Ma W., Velthof G., Qin W., Oenema O., Zhang F. (2013) Environmental assessment of management options for nutrient flows in the food chain in China. Environ Sci Technol 47:7260-8. DOI: 10.1021/es400456u.

McDonald P., Edwards R.A., Greenhalgh J.F.D., Morgan C.A., Sinclair L.A., Wilkinson R.G. (2010) Animal Nutrition. Seventh Edition. Prentice Hall, Pearson, Harlow England. $714 \mathrm{pp}$. 
Mekonnen A. (2017) Effects of Seeding Rate and Row Spacing on Yield and Yield Components of Bread Wheat (Triticum Aestivum L.) in Gozamin District, East Gojam Zone, Ethiopia Journal of Biology, Agriculture and Healthcare 7:19-37.

Murphy J., Riley J.P. (1962) A modified single solution method for the determination of phosphate in natural waters. Analytica Chimica Acta 27:31-36. DOI: https://doi.org/10.1016/S0003-2670(00)88444-5.

Nigussie A., Kuyper T., de Neergaard A. (2015) Agricultural waste utilisation strategies and demand for urban waste compost: Evidence from smallholder farmers in Ethiopia. Waste Manag 44:82-93. DOI: 10.1016/j.wasman.2015.07.038.

Novozamsky I., Eck R.v., Schouwenburg J.C.v., Walinga I. (1974) Total nitrogen determination in plant material by means of the indophenol-blue method. Neth. J. agric. Sei. 22:3-5.

Oenema O., Tamminga S. (2005) Nitrogen in global animal production and management options for improving nitrogen use efficiency. Sci China C Life Sci 48 Spec No:87187.

Piper C.S. (1966) Soil and plant analysis : a laboratory manual of methods for the examination of soils and the determination of the inorganic constituents of plants Hans, Bombay.

Roberts T. (2008) Improving Nutrient Use Efficiency. Turk J Agric 32:177-182.

Rodd A. V., Warman P. R., Hicklenton P., K. W. (2002) Comparison of N fertilizer, sourceseparated municipal solid waste compost and semi-solid beef manure on the nutrient concentration in boot-stage barley and wheat tissue. Can. J. Soil Sci. 82:33-43

Rufino M.C., Rowe E.C., Delve R.J., Giller K.E. (2006) Nitrogen cycling efficiencies through resource-poor African crop-livestock systems. Agriculture, Ecosystems \& Environment 112:261-282. DOI: 10.1016/j.agee.2005.08.028.

Schonfeldt H.C., Hall N.G. (2012) Dietary protein quality and malnutrition in Africa. Br J Nutr 108 Suppl 2:S69-76. DOI: 10.1017/S0007114512002553.

Sinclair R. (1967) Von ThÜnen and Urban Sprawl. Annals of the Association of American Geographers 57:72-87. DOI: 10.1111/j.1467-8306.1967.tb00591.x.

Snijders P., Davies O., Bram W., Louis G., Joshua Z., Peter E., Kebebe E., Muktar A., van Keulen H. (2009) Cattle manure management in East Africa: Review of manure quality and nutrient losses and scenarios for cattle and manure management, Integrated Nutrient Management to Attain Sustainable Soil Productivity increases in East African farming systems (INMASP).

Strokal M., Ma L., Bai Z., Luan S., Kroeze C., Oenema O., Velthof G., Zhang F. (2016) Alarming nutrient pollution of Chinese rivers as a result of agricultural transitions. Environmental Research Letters 11. DOI: 10.1088/1748-9326/11/2/024014.

Tadesse S.T., Oenema O., van Beek C., Ocho F.L. (2018) Diversity and nutrient balances of urban and peri-urban farms in Ethiopia. Nutrient Cycling in Agroecosystems 111:1-18. DOI: $10.1007 / \mathrm{s} 10705-018-9911-0$.

Tadesse S.T., Oenema O., van Beek C., Ocho F.L. (2019) Nitrogen allocation and recycling in peri-urban mixed crop-livestock farms in Ethiopia. Nutrient Cycling in Agroecosystems 115:281-294. DOI: 10.1007/s10705-018-9957-z.

Tulema B., Aune J.B., Breland T.A. (2007) Availability of organic nutrient sources and their effects on yield and nutrient recovery of tef [Eragrostis tef (Zucc.) Trotter] and on soil properties. Journal of Plant Nutrition and Soil Science 170:543-550. DOI: 10.1002/jpln.200521781.

UN. (2019) World Urbanization Prospects: The 2018 Revision (ST/ESA/SER.A/420), United Nations, New York.

van Beek C.L., Elias E., Yihenew G.S., Heesmans H., Tsegaye A., Feyisa H., Tolla M., Melmuye M., Gebremeskel Y., Mengist S. (2016) Soil nutrient balances under diverse 
agro-ecological settings in Ethiopia. Nutrient Cycling in Agroecosystems 106:257-274. DOI: $10.1007 / \mathrm{s} 10705-016-9803-0$.

van Middelkoop J.C., Holshof G. (2017) Nitrogen Fertilizer Replacement Value of Concentrated Liquid Fraction of Separated Pig Slurry Applied to Grassland. Communications in Soil Science and Plant Analysis 48:1132-1144. DOI: 10.1080/00103624.2017.1323101.

Velthof G.L., van Beusichem M.L., Raijmakers W.M.F., Janssen B.H. (1998) Relationship between availability indices and plant uptake of nitrogen and phosphorus from organic products. Plant and Soil 200:215-226. DOI: 10.1023/A:1004336903214.

Wang F., Wang Z., Kou C., Ma Z., Zhao D. (2016) Responses of Wheat Yield, Macro- and Micro-Nutrients, and Heavy Metals in Soil and Wheat following the Application of Manure Compost on the North China Plain. PLOS ONE 11:1-18. DOI: 10.1371/journal.pone.0146453.

Wang M., Ma L., Strokal M., Chu Y., Kroeze C. (2018) Exploring nutrient management options to increase nitrogen and phosphorus use efficiencies in food production of China. Agricultural Systems 163:58-72. DOI: 10.1016/j.agsy.2017.01.001.

Webb J., Sørensen P., Velthof G., Amon B., Pinto M., Rodhe L., Salomon E., Hutchings N., Burczyk P., Reid J. (2013) An Assessment of the Variation of Manure Nitrogen Efficiency throughout Europe and an Appraisal of Means to Increase Manure-N Efficiency. pp. 371-442.

Wei Y., Zhao Y., Xi B., Wei Z., Li X., Cao Z. (2015) Changes in phosphorus fractions during organic wastes composting from different sources. Bioresour Technol 189:349-356. DOI: 10.1016/j.biortech.2015.04.031.

Wilkinson S.R. (1979) Plant Nutrient and Economic Value of Animal Manures. JOURNAL OF ANIMAL SCIENCE 48:14.

Workicho A., Belachew T., Feyissa G.T., Wondafrash B., Lachat C., Verstraeten R., Kolsteren P. (2016) Household dietary diversity and Animal Source Food consumption in Ethiopia: evidence from the 2011 Welfare Monitoring Survey. BMC Public Health 16:1192. DOI: 10.1186/s12889-016-3861-8.

Yokota T., Ito T., Saigusa M. (2003) Measurement of total phosphorus and organic phosphorus contents of animal manure composts by the dry combustion method. Soil Science and Plant Nutrition 49:267-272. DOI: 10.1080/00380768.2003.10410006.

Zamil S.S., Halim M.A., Ashraf-Uz-Zaman K., Chowdhury M.A.H. (2015) Available nitrogen and phosphorus release pattern from poultry manure, cow-dung and bio-gas slurry. International journal of Business, Social and Scientific Research 3:136-142.

Zhang F., Chen X., Vitousek P. (2013) Chinese agriculture: An experiment for the world. Nature 497:33-5. DOI: 10.1038/497033a.

Zhang X., Davidson E.A., Mauzerall D.L., Searchinger T.D., Dumas P., Shen Y. (2015) Managing nitrogen for sustainable development. Nature 528:51-59. DOI: $10.1038 /$ nature 15743 . 
SUMMARY 


\section{Introduction}

Urbanization is one of the major social changes sweeping the globe and currently, over half of the world's population lives in urban areas. It has multiple drivers and multiple effects. It influences human diets and global food demand, because it is the result of a growth in nonfood producers and of their average incomes. Thus, urbanization often provides growing demands for high value agricultural products and also affects nutrient recycling and regional nutrient budgets. As a result of the demographic movement into the cities, nutrients flow towards the urban zone leading to nutrient accumulation in urban areas. The transfer of nutrients to urban areas equally contributes to nutrient depletion in rural areas, where most of the food is produced.

Urbanization may also go along with increasing urban poverty, growing food insecurity and pollution of the environment, especially in developing countries. For reducing the problems of urban wastes, improving urban biodiversity and overall abating the environmental impacts of food transport to urban areas and addressing urban food insecurity, urban and peri-urban agriculture (UPA) may have a role to play. UPA is a response to the expensive and often inadequate food supply in the rapidly increasing urban areas as it provides employment, income and food security to low-income urban residents. This is the case also in Sub Saharan African countries, including Ethiopia, which are dented by poverty, rapid population growth and environmental degradation.

Ethiopia is among the rapidly developing countries in SSA and the second populous country in Africa following Nigeria (UN, 2015). UPA is becoming important for the livelihood of millions of urban residents providing jobs, food and income in rapidly growing cities. But, the diversity and socioeconomic and environmental performances of the UPA farm systems are largely unknown in Ethiopia. The extent, types and practices of UPA may vary across Ethiopian cities due to differences in socioeconomic conditions and urbanization patterns. We know also little about nutrient flows between intensive livestock production farms and crop farms in urban, peri-urban and rural areas.

The main aim of this thesis is to increase the insights on the diversity and nutrient balances of UPA farms in Ethiopia, and on the quantitative potentials of recycling urban livestock manure and waste nutrients in urban, peri-urban and rural crop farms, for closing the urban-rural nutrient loops.

Accordingly, the following main research questions were addressed.

Q1. What are the main UPA farm types in different cities and what are the environmental (nutrient balances) and socioeconomic (income) performances of the farm types?

Q2. Is there a mechanism to understand nutrient $(\mathrm{N})$ allocation and recycling between crop and livestock compartments in mixed crop-livestock farms? 
Q3. What are the potentials and the possible impacts of recycling urban livestock manure and waste nutrients on fertilizer savings, environmental pollution, and nutrient use efficiency at system levels in urban, peri-urban and rural areas?

Q4. What is the effect of possible future developments: population growth, urbanization, UPA intensification, and improved technology on food-protein self-sufficiency, manure $\mathrm{N}$ recycling and $\mathrm{N}$ balances for the period 2015-2050 in urban, peri-urban and rural areas of Jimma city as a case study?

\section{Materials and methods}

In this thesis three research methodologies (surveys and interviews, modelling and monitoring, and scenario analysis and targeted field experiments) were used to answer my research questions. Base line surveys and interviews were conducted on 425 UPA farms in urban and peri urban areas in three main cities of Ethiopia. Categorical principal component analysis and cluster analysis were conducted using data collected from the 425 (Addis Ababa: 175, Adama: 126 Jimma: 124) UPA farming households to systematically classify the diverse UPA systems in farm typologies and quantify the nutrient flows and balances of the identified UPA farm typologies (To answer Q1).

The MonQIt (Monitoring for Quality Improvement tool) model questionnaire was used to collect data on household composition, fields and farm characteristics and nutrient management data including use of inputs for the different crops and livestock activities, flows between activities, crop yields, animal production, sales, input and output prices. CLS (crop livestock ratio), $\mathrm{N}$ (nitrogen) flows and farm income indicators were computed using combination of farm surveys, field observations and modelling (MonQIt). The CLS was used to analyze nutrient $(\mathrm{N})$ allocation and recycling between crop and livestock compartments in mixed croplivestock farms and further model calculation was done for sensitivity analysis (To answer Q2).

The MonQIt model was used for inventory of nutrient balances in urban, peri-urban and rural farms, and for estimating the potentials of recycling urban livestock manures and wastes from urban city centers to the urban peripheries, peri-urban and rural areas within feasible distances in the three main city regions of Ethiopia (To answer Q3).

Exploratory scenarios were designed and a simple $\mathrm{N}$ mass flow model was developed to analyze the effects of possible future developments: increased urbanization, intensification of UPA and increased technological developments on food-protein self-sufficiency, manure $\mathrm{N}$ recycling and $\mathrm{N}$ balances. The expected economic costs and environmental benefits of this recycling were also explored. Targeted field experiments were also conducted to test the agronomic, environmental and socioeconomic effects of 5 types of urban livestock manures and kitchen wastes composts on wheat in peri-urban settings of Jimma urban region (To answer Q4). 


\section{Results}

Following the systematic classification of UPA farms, four UPA farm types per city and six in total across the three cities were identified and characterized on the basis of their primary farming objectives, resource endowments, use of agricultural waste for soil fertility management, nutrient balances and income levels (Chapter 2). Among the six farm types identified, commercial livestock farms were economically the most important as they generate the highest net farm income. The majority of the commercial livestock farms in this study were land-less and almost all feeds were scavenged and/or purchased from other regions. The remaining five farm types were mixed livestock, vegetable crops and field crops farming systems with different levels of integration and with relatively larger land holding. The UPA farm types differed in the use of agricultural wastes, crop residues and manure for soil fertility management, in the level of intensification and in partial nitrogen $(\mathrm{N})$, phosphorus $(\mathrm{P})$ and potassium balances $\mathrm{K}$ balances. The commercial livestock farms accumulated $450 \mathrm{~kg} \mathrm{~N}, 85 \mathrm{~kg}$ $\mathrm{P}$ and $260 \mathrm{~kg} \mathrm{~K} \mathrm{ha}^{-1}$ year $^{-1}$ while the field crop systems depleted the soil $(-30 \mathrm{~kg} \mathrm{~N}$ and $-17 \mathrm{~kg}$ $\mathrm{K} \mathrm{ha}^{-1}$ year $^{-1}$ ) as there was little/no manures and crop residues exchange between livestock farms and crop farms.

Mixed crop-livestock farms were identified in Chapter 2 as one of the six farm types. In response to the increasing food demand of the urban population, mixed crop-livestock farms are recognized as multifunctional systems that provide a significant fraction of the necessary food, through both crop and livestock production activities. For these farm types we derived the crop-livestock ratio (CLS) as an indicator for the analysis of $\mathrm{N}$ flows and allocation to crop and livestock compartments within the mixed crop-livestock farms. The indicator provides information about the relative allocation of the external $\mathrm{N}$ inputs to the soil/crop and livestock compartments in mixed farms. The CLS indicator helped us to distinguish crop-oriented and livestock-oriented mixed crop-livestock farms, which differed in partial $\mathrm{N}$ balance, $\mathrm{N}$ use efficiency, and net farm income (Chapter 3).

Urban livestock farms appeared economically most attractive, but these farms had large manure nutrient accumulation. I estimated the potentials of collecting and recycling manure nutrients from the livestock farms, for closing the rural-urban nutrient loops. Accordingly, 0.5-2.6 Gg $\mathrm{N}$, 0.2-0.8 Gg P and 0.9-3.7 Gg K may be collected in manure from urban livestock farms in Addis Ababa, and 0.04-0.22 Gg N, 0.02-0.07 Gg P and 0.07-0.30 Gg K from urban livestock farms in Jimma, and these quantities can be recycled to croplands per year. Further, following the envisaged recycling, the same magnitudes of nutrients ( $\mathrm{N}, \mathrm{P}$ and $\mathrm{K}$ ) can be saved from polluting the soil, surface waters and groundwater in and around livestock farms, and from threatening food safety, human health and biodiversity of the urban regions (Chapter 4).

Effects of possible of future developments such as increased urbanization, UPA intensification and increased technological developments were explored on food-protein self-sufficiency, manure $\mathrm{N}$ recycling and $\mathrm{N}$ balances. In the 'business as usual' (BAU) scenario with rapid population growth and stagnant yields, food self-sufficiency of the whole city area will 
decrease to $35 \%$ in 2050. In the scenario with increased urbanization (URBAN), where a steady crop yield increase of $3 \% \mathrm{yr}^{-1}$ was assumed, food self-sufficiency will drop below $100 \%$ indicating the need to import food (Chapter 5).

Household waste and manure $\mathrm{N}$ production increased much faster in the URBAN scenario than in the BAU scenario. The projected increase was most notable in urban and peri-urban areas of scenarios with increased urbanization and increased UPA (UPALP), as $37 \%$ of total manure production will occur in the urban and $63 \%$ in the rural areas. In the BAU scenario, only $18 \%$ of the amount of $\mathrm{N}$ in manures and kitchen wastes was recovered as compost for recycling to croplands while $39 \%$ of the $\mathrm{N}$ from kitchen wastes and manures was recovered in the scenario with enhanced technological development (TECH), because of improved manure collection and use of emission mitigation techniques.

In the BAU scenario, mean farm-gate $\mathrm{N}$ surpluses in UPA increased from $240 \mathrm{~kg} \mathrm{ha}^{-1}$ in 2015 to $480 \mathrm{~kg} \mathrm{ha}^{-1}$ in 2050, and in the rural area from 90 to $150 \mathrm{~kg} \mathrm{ha}^{-1}$. Farm-gate $\mathrm{N}$ surpluses in UPA will increase rapidly in the URBAN and UPALP scenarios, especially in the urban areas due to increasing urban food demand and the concomitant intensification of urban livestock production. However, increases will be much less in the TECH scenario due to the assumed increase in food production efficiency and use of emission mitigation techniques (Chapter 5).

Expected economic costs and environmental benefits of manure $\mathrm{N}$ recycling were also explored. The total cost of compost production will increase because the volume of compost increases and the total amount of compost $\mathrm{N}$ available in 2050 is likely to range between 1.5 $\mathrm{Gg}$ in the BAU scenario to $4 \mathrm{Gg}$ in URBAN and UPLP scenarios $(2 \mathrm{Gg} \mathrm{N}$ in the TECH scenario). My estimations suggest that the costs of manure nutrients were comparable to the costs of nutrients from synthetic fertilizers. The costs of composting were expected to increase threefold in the TECH scenario due to the investments in sheltered barns with leak-tight floors and leak-tight and covered manure stores (Chapter 5).

\section{Conclusions}

The main conclusions of this thesis are:

$>$ Six distinct UPA farm types with different resource endowments, level of household income and constraints were identified across the studied urban areas of Addis Ababa, Adama and Jimma. High costs of feed for livestock farms, high cost of nutrient and labor inputs for crop and vegetable farms, and land scarcity were the most important constraints for further UPA development. Therefore, to stimulate sustainable intensification of UPA, the access of farms to agricultural inputs should be improved and policies promoting the linking of crop and livestock farm systems should be put in place.

$>$ Mixed crop-livestock farms are dominant UPA systems. The diversity of mixed farms was captured by the crop-livestock ratio (CLS). Crop-oriented and livestock-oriented mixed 
farms were distinguished, which differed in farm income, $\mathrm{N}$ balances and nitrogen use efficiency.

Livestock farms in the urban zones of Addis Ababa and Jimma produce more manure N, P and $\mathrm{K}$ than the demand of crop farms in the urban zones of these cities. A balanced $\mathrm{P}$ fertilization strategy was preferred to a balanced $\mathrm{N}$ fertilization strategy for estimating the allocation of manure in crop farms. Therefore, a balanced $\mathrm{P}$ fertilization strategy should be used for the allocation of urban livestock manures and wastes and of their compost's allocation to croplands.

Results of scenarios analyses indicated that animal-source food demand and thereby total manure $\mathrm{N}$ production in urban and peri-urban areas will likely increase by a factor of 3 to 10 in Jimma during the next three decades in response to population growth, urbanization and UPA intensification. This puts enormous pressure on agriculture and the environment. Three actions have been suggested to alleviate the pressures: (1) a slowdown in population growth and urbanization, (2) improvements in crop and animal productivity and (3) improved collection and utilization of manures and household. 


\section{SAMENVATTING}




\section{Inleiding}

Verstedelijking is een van grootste sociale veranderingen die momenteel plaatsvindt op de wereld. Momenteel leeft meer dan de helft van de wereldbevolking in stedelijke gebieden. Veel mensen trekken van het platteland naar de stad vanwege de daar aanwezig werkgelegenheid en voorzieningen. Verstedelijking heeft verschillende effecten tot gevolg. Zo verandert het dieet van de mensen als ze van het platteland naar de stad trekken, en daardoor de vraag naar voedsel. De vraag naar dierlijk eiwit, groenten en fruit neemt toe, terwijl de consumptie van traditionele voedingsingrediënten afneemt. Daarmee zorgt verstedelijking voor een stijgende vraag naar hoogwaardige landbouwproducten. Indirect veranderen daardoor ook regionale nutriëntenkringlopen en nutriëntenbalansen. De demografische verschuiving richting de stad resulteert in een stroom van nutriënten richting de stedelijke omgeving en zorgt voor een accumulatie van nutriënten in de stad. De overdracht van nutriënten richting de stedelijke omgeving zorgt tegelijkertijd voor een verarming aan nutriënten in landelijke gebieden, waar het meeste voedsel wordt geproduceerd, vooral als de afvoer van nutriënten met het geoogste gewas niet of onvoldoende wordt gecompenseerd. Verstedelijking gaat vaak ook gepaard met meer armoede, voedselonzekerheid en milieuverontreiniging, vooral in ontwikkelingslanden.

Stedelijke en voorstedelijke landbouw (SVL, in het Engels UPA: urban and peri-urban argriculture) heeft een belangrijke rol in de voedselvoorziening en het verschaffen van werkgelegenheid aan de stedelijke bevolking. SVL kan ook bijdragen aan het benutten van organisch afval in de stad, het verhogen van de biodiversiteit, en aan het verminderen van de milieu-impact van voedseltransport van platteland naar stad. SVL is een tegenreactie op veelal dure en vaak inadequate voedselvoorziening in de snelgroeiende stedelijke omgeving, omdat het zorgt voor werkgelegenheid, inkomen en voedselzekerheid voor de stedelingen met een laag inkomen. Deze trend geldt ook voor landen als Ethiopië in Sub-Sahara-Afrika, waar armoede, snelle populatiegroei en degradatie van het milieu aan de orde van de dag zijn.

Ethiopië is een van de snelst groeiende landen in Sub-Sahara-Afrika en op Nigeria na het meest dichtbevolkte land in Afrika. SVL is belangrijk voor het levensonderhoud van miljoenen stedelingen. Maar de diversiteit, socio-economische aspecten en milieuprestaties van SVL zijn grotendeels onbekend in Ethiopië. De omvang, typen en toepassing van SVL varieert hoogstwaarschijnlijk tussen steden in Ethiopië, vanwege verschillen in socio-economische status en patronen van verstedelijking. Daarnaast is ook veel onbekend over de stroom van nutriënten tussen intensieve veehouderij en akkerbouw in stedelijke en voorstedelijke landbouw.

Het doel van dit proefschrift is om meer inzicht te verschaffen in de diversiteit en nutriëntenbalansen van verschillende SVL-boederijen in Ethiopië. Daarnaast wordt kwantitatief ingegaan op de potentie van het sluiten van de nutriëntenkringlopen tussen de stad en het landelijk gebied, door het recyclen van afval en mest van urbane veehouderijbedrijven als input voor akkerbouw in stedelijke, voorstedelijke en landelijke gebieden. 
De volgende onderzoeksvragen zijn hierbij geformuleerd:

Q1. Wat zijn de belangrijkste SVL-typen in verschillende steden en hoe presteren deze bedrijven wat betreft het milieu (nutriëntbalansen) en socio-economische factoren (inkomen)?

Q2. Is er een mechanisme of indicator waarmee de toewijzing van nutriënten tussen gewas- en veehouderijonderdelen binnen gemengde landbouwsystemen gekarakteriseerd kan worden?

Q3. Wat zijn de potentie en gevolgen van het recyclen van mest- en afvalnutriënten uit stedelijke veehouderijbedrijven op het mestgebruik, de milieu-impact, het nutriëntgebruik en -efficiëntie in stedelijke, voorstedelijke en landelijke gebieden?

Q4. Wat zijn de mogelijke effecten van ontwikkelingen in verdere bevolkingsgroei, verstedelijking, SVL-intensivering, en van verbeterde technologie voor de voedselzelfvoorziening van de stedelijke bevolking, voor het recyclen van mest en voor de stikstofbalansen van bedrijven in stedelijke, voorstedelijke en landelijke gebieden van de stad Jimma gedurende de periode 2015-2020?

\section{Materiaal en Methoden}

Voor dit proefschrift zijn drie onderzoeksmethoden gebruikt (enquêtes en interviews, modelleren en monitoren, en scenario-analyses en veldexperimenten). Internviews en enquêtes zijn afgenomen bij 425 SVL-boerderijen in de stedelijk en voorstedelijke gebieden in drie steden in Ethiopië. Componenten- en clusteranalyses zijn gebruikt om de 425 (Addis Ababa: 175, Adama: 126, Jimma: 124) SVL-boerderijen systematisch te classificeren in verschillende VSL-typen en om per VSL-type de nutriëntenstromen en -balansen te kwantificeren (Q1).

Het MonQIt model (Tool voor Monitoring voor Kwaliteitsverbetering) is gebruikt om data te verkrijgen over gezinssamenstelling, kenmerken van boerderijen en nutriëntenbeheer, nutriëntstromen, gewasopbrengsten, dierlijke productie, verkoop, input- en outputprijzen. De indicator CLS (gewas-vee ratio), stikstofstromen en bedrijfsinkomensindicatoren werden berekend met behulp van een combinatie van boerderij-enquêtes, veldwaarnemingen en modellering. De indicator CLS is verder gebruikt om de verplaatsing en de recycling van stikstof tussen gewas- en veehouderijonderdelen in gemengde landbouwsystemen te analyseren (Q2).

Het MonQIt model is ook gebruikt om de nutriëntbalansen in stedelijke, voorstedelijke en landelijke gebieden te bepalen en om de potentie te schatten van het recyclen van mest uit stedelijke veehouderij en afval uit stadcentra voor stedelijke periferieën, voorstedelijke gebieden en landelijke gebieden (Q3).

Verkennende scenario's zijn ontworpen en een stikstofstromenmodel is ontwikkeld om de effecten van mogelijke toekomstige ontwikkelingen op het gebied van toegenomen verstedelijking, intensivering van SVL en technologische ontwikkelingen te analyseren. De 
economische kosten en milieuvoordelen van hergebruik van nutriënten uit mest en huishoudafval werden berekend. Er zijn ook veldexperimenten uitgevoerd om de effectiviteit van 5 soorten compost (dierlijke mesten en keukenafval) als meststof voor de teelt van tarwe te testen (Q4).

\section{Resultaten}

De systematische classificatie van de onderzochte SVL-boerderijen resulteerde in vier typen SVL per stad en in totaal zes typen voor de drie steden gezamenlijk. De zes bedrijfstypen onderscheidden zich op basis van hun primaire landbouwdoelstellingen, kapitaal en bedrijfsmiddelen, gebruik van dierlijke mest voor bodemverbetering, nutriëntenbalansen en inkomensniveaus (hoofdstuk 2). Van de zes onderscheiden SVL-typen genereerden veebedrijven die voor de markt produceerden het hoogste netto bedrijfsinkomen. Het merendeel van deze veebedrijven was landloos; bijna al het voer werd bij elkaar gescharreld en/of gekocht uit andere regio's. Overige dominante SVL-typen waren: gemengde bedrijven met veeteelt en akkerbouw, groenteteeltbedrijven, en akkerbouwbedrijven, producerend voor de markt of voor eigen levensonderhoud. Akkerbouwbedrijven hadden het grootste areaal aan landbouwgrond. De SVL-typen verschilden in het gebruik van dierlijke mest, gewasresten en huishoudelijk afval voor bodemverbetering, en hadden ook onderscheidenlijke stikstof- $(\mathrm{N})$, fosfor- $(\mathrm{P})$ en kalium- $(\mathrm{K})$ balansen. De landloze veehouderijbedrijven hadden een overschot van $450 \mathrm{~kg} \mathrm{~N}, 85 \mathrm{~kg} P$ en $260 \mathrm{~kg} \mathrm{~K}$ per hectare per jaar, terwijl de akkerbouwbedrijven een tekort aan $\mathrm{N}$ en $\mathrm{K}$ op de balans hadden en de bodem uitputten $(-30 \mathrm{~kg} \mathrm{~N}$ en $-17 \mathrm{~kg} \mathrm{~K}$ per ha per jaar). Er was weinig tot geen uitwisseling van mest en gewasresten tussen de veebedrijven en akkerbouwbedrijven.

Stedelijke veebedrijven waren economisch gezien het meest interessant, maar deze bedrijven hadden relatief grote mestoverschotten. Ik heb de potentie van het verzamelen van mest en afval in stedelijke gebieden en het benutten van de nutriënten in mest en afval op akkerbouwbedrijven in de stad en het platteland uitgerekend. Hieruit volgde dat er $0,5-2,6 \mathrm{Gg}$ $\mathrm{N}, 0,2-0,8 \mathrm{Gg}$ P en $0,9-3,7 \mathrm{Gg} \mathrm{K}$ kan worden verzameld uit mest van stedelijke veebedrijven in Addis Abeba, en 0,04-0,22 Gg N, 0,02-0,07 Gg P en 0,07-0,30 Gg K van stedelijke veehouderijen in Jimma ( $1 \mathrm{Gg}=1$ miljoen $\mathrm{kg}$ ). Deze hoeveelheden kunnen per jaar worden gerecycled en gebruikt op akkerland. Een bijkomend voordeel van deze beoogde recycling is dat dezelfde hoeveelheden nutriënten ( $N, P$ en $\mathrm{K}$ ) niet onbenut in de bodem, het oppervlaktewater en grondwater in en rond veebedrijven terechtkomen. Daardoor nemen de risico's af voor voedselveiligheid, menselijke gezondheid en de aantasting van de biodiversiteit in de stedelijke regio's (Hoofdstuk 4).

In hoofdstuk 5 zijn de effecten van een toename van verstedelijking, SVL-intensivering en technologische ontwikkelingen op voedselzekerheid, mestrecycling en stikstofbalansen onderzocht voor Jimma, een middelgrote stad in Ethiopië. Daarbij is gebruik gemaakt van scenario-analyses en modelberekeningen. In het 'business as usual' (BAU)-scenario met snelle bevolkingsgroei en stagnerende gewasopbrengsten, zal de voedselzelfvoorziening van het hele 
stadsgebied in 2050 zijn afgenomen tot $35 \%$. In het scenario met versnelde verstedelijking (URBAN), maar met een aangenomen gestage stijging van de gewasopbrengst van $3 \%$ per jaar, zal de voedselzelfvoorziening ook dalen onder de $100 \%$. Ook dan zal het nodig zijn om voedsel van elders aan te voeren (Hoofdstuk 5).

De productie van huishoudelijk afval en dierlijke mest nam veel sneller toe in het URBANscenario dan in het BAU-scenario. De toename van de mestproductie in de stedelijke en voorstedelijke gebieden was het grootst in het scenario met versterkte verstedelijking en intensivering van SVL (scenario UPALP). De resultaten geven dat dat in totaal $37 \%$ van de totale mestproductie in de stad plaatsvond en $63 \%$ in de landelijke gebieden. In het BAUscenario werd slechts $18 \%$ van de hoeveelheid stikstof in de geproduceerde mest en keukenafval teruggewonnen als compost voor recycling naar akkerland, terwijl 39\% van de stikstof in de geproduceerde mest en keukenafval teruggewonnen in het scenario met verbeterde technologische ontwikkeling (TECH). De verdubbeling in hergebruik van stikstof kwam door een verbeterde mestverzameling en door het gebruik van emissiereductietechnieken.

In het BAU-scenario nemen de gemiddelde stikstofoverschotten van VSL-boerderijen toe van $240 \mathrm{~kg}$ per hectare in 2015 tot $480 \mathrm{~kg}$ per hectare in 2050, en in het landelijke gebied van 90 naar $150 \mathrm{~kg}$ per hectare. Stikstofoverschotten op boerderijniveau in SVL nemen toe in de URBAN- en UPALP-scenario's, vooral in de stedelijke gebieden, als gevolg van de toenemende vraag naar voedsel en de daarmee gepaard gaande intensivering van de stedelijke veehouderij. De resultaten van het TECH-scenario geven aan dat de stikstofoverschotten fors beperkt kunnen worden indien de efficiëntie van de voedselproductie fors verbetert en het gebruik van emissiereductietechnieken toeneemt (Hoofdstuk 5).

Ook werden de verwachte economische kosten en milieuvoordelen van mestrecycling onderzocht. De totale kosten van compostproductie zullen stijgen, omdat het compostvolume toeneemt. De totale hoeveelheid compoststikstof die in 2050 beschikbaar zal zijn, zal waarschijnlijk variëren van $1,5 \mathrm{Gg}$ in het BAU-scenario tot $4 \mathrm{Gg}$ in URBAN- en UPALPscenario's (2 Gg N in de TECH-scenario's). Mijn schattingen suggereren dat de kosten van nutriënten uit gerecyclede mest vergelijkbaar zijn met de kosten van nutriënten uit kunstmest. Verwacht wordt dat de kosten van compostering in het TECH-scenario verdrievoudigen door de investeringen in overdekte stallen met lekdichte vloeren en lekdichte en overdekte mestopslagplaatsen (Hoofdstuk 5).

\section{Conclusies}

De belangrijkste conclusies van het onderzoek in mijn proefschrift zijn:

$>$ In Addis Abeba, Adama en Jimma werden zes verschillende SVL-bedrijfstypes onderscheiden, die sterk verschillen in oriëntatie op de markt, kapitaal en bedrijfsmiddelen, gezinsinkomens en beperkingen. De belangrijkste beperkingen voor de verdere ontwikkeling van de SVL-bedrijven waren: schaarste aan land, hoge kosten van veevoer, 
hoge kosten voor kunstmest en arbeid voor akkerbouw en groenteteelt. Om duurzame intensivering van SVL te stimuleren, is het belangrijk dat er beleid komt dat gericht is op de koppeling van akkerbouw en veehouderij, met betrekking tot de uitwisseling van veevoer en dierlijke mest.

$>$ Gemengde bedrijven met akkerbouw en vee zijn veelvoorkomende SVL-systemen. De diversiteit van gemengde bedrijven kan goed worden weergegeven door de verhouding van de hoeveelheden stikstof die naar akkerbouwgewassen gaat en die via het veevoer naar het vee gaat. Die verhouding is aangeduid met de CLS-indicator. Er werd onderscheid gemaakt tussen gewasgeoriënteerde en veehouderijgerichte gemengde bedrijven; deze bedrijven verschilden sterk in bedrijfsinkomen, stikstofbalansen en stikstofgebruiksefficiëntie.

$>$ Veehouderijbedrijven in de stedelijke zones van Addis Abeba en Jimma produceren meer mest $\mathrm{N}, \mathrm{P}$ en $\mathrm{K}$ dan de akkerbouwbedrijven in de stedelijke zones van deze steden kunnen benutten. Een bemestingsstrategie gebaseerd op fosfaatevenwichtsbemesting had de voorkeur boven een strategie gebaseerd op stikstofevenwichtsbemesting, bij de toewijzing van mest op akkerbouwbedrijven.

Resultaten van scenarioanalyses gaven aan dat de vraag naar voedsel uit dierlijke bronnen in Jimma de komende drie decennia waarschijnlijk met een factor 3 tot 10 zal toenemen als gevolg van bevolkingsgroei en verstedelijking. Dit legt een enorme druk op de landbouw en het milieu. Er zijn drie maatregelen voorgesteld om deze druk te verlichten: (1) vertraging van de bevolkingsgroei en verstedelijking, (2) verbetering van de productiviteit van gewassen en dieren en (3) verbeterde inzameling en gebruik van mest en huishoudelijk afval in de landbouw. 


\section{ACKNOWLEDGMENTS}


From the beginning to the end, it would have not been possible to endure and go through my $\mathrm{PhD}$ trajectory and finally complete this doctoral thesis without the support and prayers of the generous people around me to only some of whom it is possible to give particular mention here.

I am greatly indebted to my promoter Professor Oene Oenema and my co-promoter Dr. Christy van Beek. Dear both, thank you very much for believing in me and accepting me as your student.

Professor Oene Oenema, my mentor and promoter, working with you is a privilege that I always appreciate and remember. I am lucky for being your student and for which I am proud forever. Your critical comments and suggestions, inspiring and energizing advices and your motivating ideas and encouragements were instrumental and soothing for my confidence and performances. Professor Oene Oenema, I always look up to you, your professionalism and your valuable support, guidance and amendments to the several drafted and finally published chapters and the thesis are acknowledged. Your prompt responses to my questions at any time, even during the evenings and weekends were supportive. Your wide knowledge and logical way of thinking have been of great value and you made me to grow as a scientist. I will always remember the motivation and time you invested in me that helped me to complete this thesis. You have played a significant role in my present achievement and I can't express my gratitude enough. You have always been more than just a promoter, but more of friendly and fatherly too. Thank you very much for the nice and family-hood hospitality at your home during my hard time, pain on my right hand and very interesting visits at the camping site, University of Groningen and cycling to see the beautiful village, where you are living and its surroundings. I am grateful to you for sharing your interesting social life experiences and lessons during my stay at your place, Paterswolde. To your motherly wife, Jodien Houwers, I am grateful for everything you did to make me feel just home and one member of the family. I never forget this. I admire your courage, the care and kindness you showed me while I was at your place. I want to say "Vell Dank" to you both and your esteemed family.

I would like to thank my co-promoter Dr. Christy van Beek for providing me with a solid base and framework of the MonQIt model. Dear Dr. Christy, you were there for me when I needed you most. I would like to acknowledge the moral and professional supports I received from you. I benefited much from your wisdom and wide experiences in research and scientific writing. Your advice, support, encouragement and understanding have been great treasures to me. I appreciate the time and exhaustive effort you put into this thesis and the useful suggestions and comments and critical reviews during the preparation of manuscripts. I am grateful for everything you did to make me feel just home, preparing dinners every time on my arrivals to Wageningen. I enjoyed the delicious dishes and the accompany of your husband, Luc and the whole family at your place. You were also one of the founding scientists and scientific coordinator of the CASCAPE project and a friendly colleague among the project management team from Wageningen, the Netherlands. I enjoyed working with you while I was the coordinator of Jimma University based CASCAPE project coordination unit and during the long and challenging journey of my PhD study. 
I am very grateful to my local supervisor Professor Fikre Lemessa, who has always been my pillar and with whom I share a lot, you have always been a brother to me and I am grateful for your support and writing recommendation letter helpful for my application to secure this sandwich PhD Scholarship. Dear Prof Fikre, your motivational suggestions and compliments during proposal writing, field research work and writing this thesis were instrumental for my current achievement. My deepest gratitude also goes to my role model, H.E. Dr. Kaba Urgessa, former State Minster, Ministry of Agriculture and Ethiopian delegate at FAO head quarter in Italy, for his moral support, sharing his experiences and encouraging me to persistently work on my $\mathrm{PhD}$ thesis.

I would like to thank Jimma University for granting me a four years study leave and extension. I acknowledge and appreciate the present and former administration of Jimma University College of Agriculture and Veterinary Medicine (JUCAVM): Professor Derbew Belew, Adugna Eneyew, Dr. Fikadu Mitiku and Ms Umi Abdulkadir for providing me logistics and research facilities. I am grateful to all my colleagues and friends at the Department of Horticulture and Plant Sciences for your constructive views and encouragements and sharing the course loads in my absence. I want to thank Alemseged Yilma, Daniel Damtew, Getachew Tibba, Adamu Tadesse, Drs, Tefere Tolera and Abayineh Amare for their support during the field experimentation and field data collection.

A special word of thanks goes to the Ethio-Netherlands CASCAPE project management team. I am grateful to Mr. Arie van kekem, Remko Vonk, Professor Eric Smalling and Dr. Eyasu Elias, the respective managers of CASCAPE and Mrs. Linda van Kleef, the project assistant for their support and facilitation of my stay at Wageningen and my research work in Ethiopia. I am grateful to the Jimma University CSACAPE coordination unit regional manager, Prof Gezahegn Berecha and the innovation team (IT) members for their full support and facilitation of my research. Dear Geze, I can't forget your encouraging and helpful advices pushing me towards the finish line.

There were many people in the Chair group Soil Quality of Wageningen University and the Soil Biology (SBL) research group who helped me a lot. I would like to thank Ma Lin and Kimo van Dijk for the useful discussions that have improved my concept of modelling. Words of thanks go to Prof Lijbert Brussaard and Prof Heike Bohne (Leibniz University of Hannover) for writing me recommendation letters that helped me in the application for this Sandwich PhD grant. I would like to thank Prof Ellis Hoffland, Prof Thom Kuyper and Prof Rachel Creamer for sharing their views, opinions and their encouraging and kind words. I am grateful and sincerely acknowledge Dr. Jeffrey van Lent for translating the English summary of this thesis to the Dutch language.

I am very grateful to Marnella van der Tol, Esther van der Brug, Anita Kok, Siawash Tajdini and Freddy Pracht for their endless support and professional services I received when I was in need. Room and ticket bookings and financial arrangements for fieldwork are part of the 
support that I received from you. Dear Marnella, I can't forget the soil quality (SOQ) outing event at your place in Putten. Many thanks.

I would like to thank Professor Ken Giller and Dr. Irene Koomen. You have been a caring family and friendly, you organized dinners for foreign $\mathrm{PhD}$ students and CASCAPE project $\mathrm{PhD}$ students, thank you for the delicious dishes and enjoyable games we had at your place in Wageningen. I am very grateful and sincerely acknowledge Joost Vlaming from Envista Consultancy for training and allowing me to use the model for my $\mathrm{PhD}$ study and continuous support on the MonQIt model data entry and processing techniques and the use and interpretations of the model results.

I would like to thank my brotherly friend Dr. Desalegn W/ Senbet and his wife Nele Prota for their kind thoughts, warm invitation to their home whenever I missed injera. Thank you, I feel home away from home. Thanks to my colleagues working in the offices and labs of Atlas building: Rima, Yong, Janna, Joana, Giulia, Ingrid, Ros, Carmen, Leonardo, Laura and my other colleagues, the nice conversations during coffee and lunch breaks made my stay in Wageningen enjoyable.

My deepest gratitude goes to my Ethiopian friends and families: Belay Duguma, Adamitu Kumssa, Bezayit Temesgen, Wubit Befikadu, Tiblet Mekkonen, Amelework Kebede, Drs. Duguma Adugna, Diriba Muleta, Girma Adugna, Melkamu Dumessa, Yetnayet Bekele, Wosene G/ Silase, Fikremariam Geda and Sirawdink Fikreyesus for their moral support and encouragement.

I am very grateful for the invaluable support of my brothers: Belay, Fikadu, Dr. Getachew and my sisters: Fikrte, Yeshe and Alemtsehay, my other brothers (Dereje Worku and Tadele Hailu), I love you so much. Nephews, Aunties, Uncles, Cousins and families, I appreciate your unreserved love and moral support during the entire period of my study. I wish to express my deep respect and love to my family, parents and my parents-in-law. You gave me full support to pursue my career abroad. In particular, I would like to thank and sincerely appreciate my wife Bezawit Mekonnen without whom this effort would have been worth nothing, and for your irreplaceable support and caring. Your love and constant patience have taught me so much about sacrifice and discipline. I greatly appreciate your encouragement and prayer for me and your full support and compassion for my family while I was in the Netherlands and your inspiration and invaluable advice for life. I am grateful to my lovely sons Naol and Kenan who endured my long absence while I was away doing my PhD. My sons Naol and Kenan thank you, without your encouragement and understanding it would have been impossible for me to finish this work. Finally, I am pleased to dedicate this thesis to my late father Tulu Tadesse and uniquely to my late mother Zenebech Zewde Aba Gurmu.

\section{Delighted}

Solomon Tulu Tadesse

Wageningen 
PUBLICATIONS 


\section{LIST OF PUBLICATIONS}

\section{IN INTERNATIONALLY PEER REVIEWED ACADEMIC JOURNALS}

1. Tadesse ST, Oenema O, Van Beek C, Ocho FL (2021b) Exploring the recycling of manure from urban livestock farms: a case study in Ethiopia. Front. Agr. Sci. Eng. doi: 10.15302/J-FASE-2020375

2. Tadesse ST, Oenema O, Van Beek C, Ocho FL (2021a) Manure recycling from urban livestock farms for closing the urban-rural nutrient loops. Journal of Nutrient Cycling in Agroecosystems. 119:51-67.

3. Tadesse ST, Oenema O, Van Beek C, Ocho FL (2019) Nitrogen allocation and recycling in peri-urban mixed crop-livestock (MC-L) farms in Ethiopia. Journal of Nutrient Cycling in Agroecosystems. 115:281-294.

4. Tadesse ST, Oenema O, Van Beek C, Ocho FL (2018) Diversity and nutrient balances of urban and peri-urban farms in Ethiopia. Journal of Nutrient Cycling in Agroecosystems. 111: 1-18.

5. Negash A, Tulu S, Getachew E (2018) Yield and Yield Components of Snap Bean (Phaseolus vulgaris L.) as affected by N and P Fertilizer Rates at Jimma, Southwestern Ethiopia. Adv Crop Sci Tech 6: 369.

6. Abdela Negash, Solomon Tulu and Essubalew Getachew (2017). Growth of Snap Bean (Phaseolus Vulgaris L.) as Affected by N and P Fertilizer Rates at Jimma, Southwestern Ethiopia. International Journal of Research in Agric. Sc. 4: 251-256.

7. Israel Zewide, Ali Mohammed and Solomon Tulu Tadesse (2016). Potato (Solanum tuberosum L.) Growth and Tuber Quality, Soil Nitrogen and Phosphorus Content as Affected by Different Rates of Nitrogen and Phosphorus at Masha District in Southwestern Ethiopia. International Journal of Agricultural Research. 11: 95-104.

8. Bayu Dume, Gezahegn Berecha and Solomon Tulu (2015). Characterization of Biochar Produced at Different Temperatures and its Effect on Acidic Nitisol of Jimma, Southwest Ethiopia. International Journal of Soil Science. 10: 63-73.

9. Bezawit Mekonnen, Solomon Tulu and Jima Nego (2015). Orange Fleshed Sweet Potato (Ipomoea batatas L.) Varieties Evaluated with Respect to Growth Parameters at Jimma in Southwestern Ethiopia. Journal of Agronomy. 14: 164-169.

10. Bezawit Mekonnen, Solomon Tulu and Jima Nego (2015). Evaluation of Orange Fleshed Sweet Potato (Ipomoea batatas L.) Varieties for Yield and Yield Contributing Parameters in the Humid Tropics of Southwestern Ethiopia. Journal of Plant Sciences. 10): 191-199.

11. Hawi Mohammed, Tesfaye Shiferaw and Solomon Tulu Tadesse (2015). Nitrogen and Phosphorus Fertilizers and Tillage Effects on Growth and Yield of Maize (Zea mays L.) at Dugda District in the Central Rift Valley of Ethiopia. Asian Journal of Crop Science. 7: 277-285.

12. Abebayehu Aticho, Misginaw Tamirat, Abraham Bantirgu, Solomon Tulu, Alemayehu Regassa and Bayu Dume (2014). Influences of mineral nitrogen and phosphorous fertilization on yield and yield contributing components in hot pepper (Capsicum annuum L.). African Journal of Agricultural Research. 9: 670-675.

13. Betewulign Eshetu and Solomon Tulu (2014). Evaluating the Role of Nitrogen and Phosphorous on the Growth Performance of Garlic (Allium sativum L.). Asian Journal of Agricultural Research. 8: 211-217.

14. Tesfaye Getachew, Derbew Belew and Solomon Tulu (2012). Yield and Growth Parameters of Potato (Solanum tuberosum L.) as Influenced by Intra Row Spacing and Time of Earthing up: In Boneya Degem District, Central Highlands of Ethiopia. International Journal of Agricultural Research. 7: 255-265. 
15. Tesfaye Getachew, Derbew Belew and Solomon Tulu (2012). Combined Effect of Plant Spacing and Time of Earthing up on Tuber Quality Parameters of Potato (Solanum tuberosum L.) at Degem District, North Showa Zone of Oromia Regional State. Asian Journal of Crop Science. 5: 24-32.

16. Israel Zewide, Ali Mohammed and Solomon Tulu (2012). Effect of Different Rates of Nitrogen and Phosphorus on Yield, and Yield Components of Potato (Solanum tuberosum L.) at Masha District, Southwestern Ethiopia. International Journal of Soil Sciences. 7: 146-156.

17. Mulatu Wakjira, Gezahegn Berecha and Solomon Tulu (2009). Allelopathic effects of an invasive alien weed Parthenium hysterophorus L. compost on lettuce germination and growth. African Journal of Agricultural Research. 4: 1325-1330.

\section{IN CONFERENCE PROCEEDINGS}

18. Solomon Tulu Tadesse, Arena van Brugen and Diriba Muleta. Comparison of Ethiopian Conventional and Organic Coffee Soil Managements with Respect to Chemical, Physical and Microbiological Soil Quality Parameters. Proceedings of the Third Biennial Conference of the Ethiopian Horticulture Science Society (EHSS), Jimma, Ethiopia, 04 05 February 2011, Jimma University College of Agriculture \& Veterinary Medicine (JUCAVM), Jimma.

19. Bezawit Mekonen, Derbew Belew, Nigussie Kassa and Solomon Tulu Tadesse. Effect of Aluminum Sulphate and Sucrose on the Vase Life of Selected Cultivars of Cut Roses (Rosa hybrida L.) at Holeta, Central Highlands of Ethiopia. Proceedings of the Third Biennial Conference of the Ethiopian Horticulture Science Society (EHSS), Jimma, Ethiopia, 04 - 05 February 2011, Jimma University College of Agriculture \& Veterinary Medicine (JUCAVM), Jimma. 



\section{ABOUT THE AUTHOR}

Solomon Tulu Tadesse was born on the $22^{\text {nd }}$ of September 1974 at Hambiso in Degem Woreda, North Showa, Ethiopia. He attended secondary education at Fitche Comprehensive and Secondary School (FCSS) in Fitche Selale. He started studying Plant Sciences at Jimma College of Agriculture (JCA) in 1992 and received his diploma in Plant Sciences with specialization in coffee, tea and spices crops production and management in June 1994. Afterwards, Solomon served as Expert of Soil and Water Conservation and Extension Supervisor at Omo-Nadda

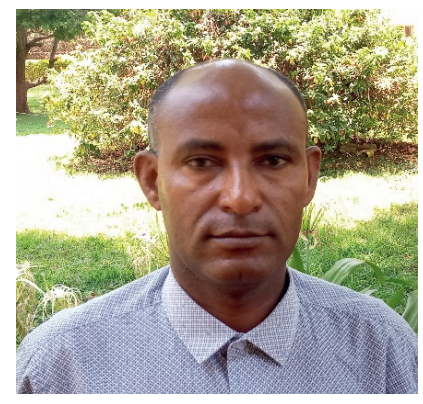
Woreda Agricultural Development office, working with development agents (DAs) and the smallholder farmers. In 2000, Solomon was employed at Jimma University and served as Technical Assistant I and II, assisting laboratory and practical classes of Tea production and management, Coffee production and processing, Plant propagation, Plant Ecology, Applied Ecology, Introduction to Soils, Soils and Plant Nutrition, Soils and Soil Management and Introduction to Forestry courses at Jimma University, College of Agriculture and Veterinary Medicine (JUCAVM) in the Department of Horticulture and Plant Sciences. In 2002, he was offered a Bachelor of Science (B.Sc.) scholarship from JUCAVM to pursue his education in agricultural sciences. He received his B.Sc. degree in Horticulture in July 2005 at Jimma University in Ethiopia. He did a project for his B.Sc. degree on "the Effect of Animal Manure and Nitrogen Fertilizer on Yield and Yield Components of Potato (Solanum tuberosum L.) on Nitisols in Jimma Area" due to his keen interest in soil biology and chemistry, soil fertility and nutrient management. After his study, he served as instructor and researcher with the capacity of Graduate Assistant I and II, teaching the courses Tropical, Sub-Tropical and Temperate Fruit Crops Production and Management, Food Sciences and Practical Horticulture at Jimma University. Besides, he served as the Head of Production Unit, currently called Income Generation Unit of the College. In 2007 Solomon was awarded a NUFFIC scholarship and received his Master of Science (M.Sc.) degree in Organic Agriculture (MOA) with specialization in Agro Ecology and Minor in Soil Quality (SOQ) from Wageningen University (WUR) in August 2009. After his M.Sc. study, Solomon served as instructor and researcher with the academic rank of Lecturer, Assistant Professor teaching the courses Introduction to Soils, Fundamentals to Soils and Organic Horticulture. He also served Jimma University with the academic rank of Associate Professor teaching: Soil Fertility and Plant Nutrition, Soil and Water, and Water and Nutrient Management courses, conducting researches and advising MSc students. Besides the academics, he served the college as a Coordinator for Post Graduate, Research and Community Based Education (CBE) Coordination Office, currently called Post Graduate and Research (PGR) Office. He also served as a coordinator for the CASCAPE (Capacity Building for Scaling up of Evidence-based Best Practices in Agricultural Production in Ethiopia) Project Coordination Unit at Jimma University until the date he joined this $\mathrm{PhD}$ study. In April 2013, Solomon started the PhD research described in this thesis at Soil Biology (SBL) research group in the Chair group of Soil Quality, Wageningen University \& Research (WUR) with the financial support of the Netherlands government in the CASCAPE project. 



\section{PE\&RC Training and Education Statement}

With the training and education activities listed below the $\mathrm{PhD}$ candidate has complied with the requirements set by the C.T. de Wit Graduate School for Production Ecology and Resource Conservation (PE\&RC) which comprises of a minimum total of 32 ECTS (= 22 weeks of activities)

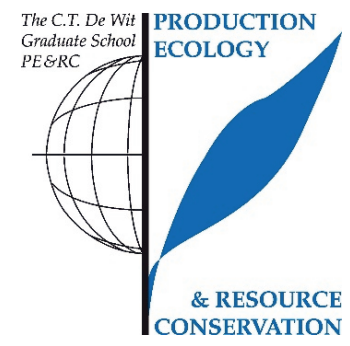

\section{Review of literature (4.5 ECTS)}

Soil fertility and nutrient management in urban, peri-urban and rural agriculture in Ethiopia

\section{Writing of Project proposal (4.5 ECTS)}

- Soil fertility and nutrient management at Regional Level in Ethiopia

\section{Post-graduate courses (9.1 ECTS)}

- Sampling in space and time for survey and monitoring of natural resources; PE\&RC (2013)

- $\quad$ Mixed linear models; PE\&RC (2013)

- Farming systems and rural livelihoods: vulnerability and adaptation; PE\&RC, WASS, WIAS (2013)

- Basic and advanced monitoring for quality improvement tool (MonQIt) training; WUR $(2013,2014)$

- Introduction to R for statistical analysis; PE\&RC, SENSE (2017)

- Advanced statistics course, design of experiments; PE\&RC, WIAS (2017)

\section{Deficiency, refresh, brush-up courses (7.5 ECTS)}

- Nutrient management; SOQ (2013)

- Basic statistics; PE\&RC (2013)

\section{Laboratory training and working visits (4.2 ECTS)}

- Soil fertility assessment technique; Ethiopian National Soils Laboratory (2013)

- Plant sample preparation and analysis; Jimma University Postharvest Laboratory (2013)

\section{Invited review of journal manuscripts (2 ECTS)}

- Ethiopian Journal of Applied Science and Technology: Phosphorus uptake and use efficiency in Ethiopian chickpea (Cicer arietinum L.) germplasm accessions grown with residual moisture on vertisol: performance evaluation.

- Ethiopian Journal of Applied Science and Technology: Response of potato (Solanum tuberosum L.) to potassium fertilizer on acid soils of Wolmera and Gumer Weredas, in the high lands of Ethiopia.

\section{Competence strengthening / skills courses (8.9 ECTS)}

Skills training workshop on workplace MSc thesis research supervision in the horticultural sciences; WUR (2012)

- Competence Assessment (CA); WGS (2013)

- Data management; WUR Library (2013)

- Reviewing a scientific paper; WGS (2013) 
- Writing grant proposals; Wageningen into Languages (2013)

- Project and time management; WUR (2016)

- Brain training; WUR Library (2016)

- Information literacy PhD including EndNote introduction; WUR Library (2016)

- Scientific writing; Wageningen into Language (2017)

- PhD Workshop carousel; WGS (2018)

\section{PE\&RC Annual meetings, seminars and the PE\&RC weekend (3.1 ECTS)}

- PE\&RC First year's weekend (2013)

- PE\&RC Last year's weekend (2017)

- PE\&RC Day (2017)

- $\quad 5^{\text {th }}$ Wageningen PhD symposium (2018)

\section{National scientific meetings / local seminars / discussion groups (5.4 ECTS)}

Workshop on material flow analysis with STAN (2013)

- Alumni-workshop on climate change \& environmental protection in Ethiopia: Main focus on climate, soils, water, waste water, solid waste and landfill (2015)

- Alumni-workshop on climate change \& environmental protection in east Africa: Solution to causes and effects (2016)

- Workshop on circular economy for soil nutrient management (2017)

- Symposium on soil fertility for food security (2017)

- Workshop on scientific publishing (2018)

\section{International symposia, workshops and conferences (4.8 ECTS)}

- Symposium on soil contamination: Scope, advances and challenges; poster presentation; Wageningen

- $\quad 3^{\text {rd }}$ International conference on manure management and valorization; poster presentation; Eindhoven

- The $7^{\text {th }}$ Annual research conference on gender equality in development and nation building: Opportunities and constraints; oral presentation; Jimma University

\section{Lecturing / supervision of practicals / tutorials (11.1 ECTS)}

- $\quad$ Soil fertility and plant nutrition (2015)

- Water and nutrient management (2016)

\section{MSc thesis supervision (3 ECTS)}

- Growth, yield and quality of snap bean (Phaseolus vulgaris L.) as affected by $\mathrm{N}$ and $\mathrm{P}$ fertilizer rates at Jimma, Southwestern Ethiopia

- Effect of phosphorus rates on growth, phosphorus (p) uptake and yield of cowpea (Vigna unguiculata L. Walp) varieties at Dabo Hana district, Southwestern Ethiopia

- Effect of NPS rate and varieties on yield and yield components of bread wheat (Triticum aestivum L.) in Jardega Jarte Woreda, Horo Guduru Wollega of Oromia, Northwestern Ethiopia

- Growth and yield of snap bean (Phaseolus vulgaris L.) influenced by NPSB blended fertilizer and chicken manure at Jimma, Southwestern Ethiopia 
FUNDING 
I am grateful for funding (grant No: 5120915001) by the Dutch Ministry of Foreign Affairs through the Embassy of the Royal Kingdom of The Netherlands in Addis Ababa, Ethiopia and CASCAPE (Capacity Building for Scaling up of Evidence-based Best Practices in Agricultural Production in Ethiopia) project. I am grateful to these agencies for funding my PhD project. 
